University of Louisville

ThinkIR: The University of Louisville's Institutional Repository

Electronic Theses and Dissertations

$8-2020$

\title{
Practicing Pan-Africanism: West Indians and governance in Kwame Nkrumah's Ghana.
}

\author{
Nicholas C. McLeod \\ University of Louisville
}

Follow this and additional works at: https://ir.library.louisville.edu/etd

Part of the African American Studies Commons, African History Commons, Intellectual History Commons, and the Political History Commons

\section{Recommended Citation}

McLeod, Nicholas C., "Practicing Pan-Africanism: West Indians and governance in Kwame Nkrumah's Ghana." (2020). Electronic Theses and Dissertations. Paper 3515.

https://doi.org/10.18297/etd/3515

This Doctoral Dissertation is brought to you for free and open access by ThinkIR: The University of Louisville's Institutional Repository. It has been accepted for inclusion in Electronic Theses and Dissertations by an authorized administrator of ThinkIR: The University of Louisville's Institutional Repository. This title appears here courtesy of the author, who has retained all other copyrights. For more information, please contact thinkir@louisville.edu. 
PRACTICING PAN-AFRICANISM: WEST INDIANS AND GOVERNANCE IN KWAME NKRUMAH'S GHANA

\title{
By
}

Nicholas C. McLeod

B.A., Bucknell University, 2011

M.A., University of Louisville, 2016

\author{
A Dissertation \\ Submitted to The Faculty of \\ College of Arts and Sciences of the University of Louisville \\ In Partial Fulfillment of the Requirements \\ For the Degree of \\ Doctor of Philosophy \\ In \\ Pan-African Studies \\ Department of Pan-African Studies \\ University of Louisville \\ Louisville, Kentucky
}

August 2020 
Copyright 2020 by Nicholas C. McLeod

All rights reserved 

PRACTICING PAN-AFRICANISM: WEST INDIANS AND GOVERNANCE IN KWAME NKRUMAH'S GHANA

\author{
By \\ Nicholas C. McLeod \\ B.A., Bucknell University, 2011 \\ M.A., University of Louisville, 2016 \\ A Dissertation Approved on
}

August 3, 2020

By the following Dissertation Committee

Dissertation Director

Dr. Tyler D. Fleming

Dr. Theresa Rajack-Talley

Dr. Kwame Essien

Dr. Charlton Yingling 


\section{DEDICATION}

For Omari. 


\section{ACKNOWLEDGEMENTS}

I would like to thank my mentors and dissertation co-chairs, Dr. Theresa Rajack-Talley and Dr. Tyler Fleming for their support, direction, and trust in me to carry out this unique study. The project could not have been completed without them.

I must also extend my deep appreciation to the other committee members, Dr. Charlton Yingling, and Dr. Kwame Essien. The guidance and rigorous feedback of these scholars maintained the historical integrity of this study.

I owe a great deal of thanks to Dr. Joy Gleason Carew for granting me access her late husband, Jan Carew's, personal papers, and for supporting his inclusion in this study.

The research for this dissertation was conducted in archives in Ghana, Trinidad and Tobago, Guyana, and the United States. I would like to thank each archivist for the care, guidance, and support they provided during my fieldwork.

I must express my gratitude to the faculty and graduate students of the Department of Pan-African Studies for providing the environment of free-flowing ideas, dialogue, and support in which this dissertation was written.

Finally, to my family for their love, prayers, and sacrifice to give me the educational opportunities that brought me to this point. 


\section{ABSTRACT \\ PRACTICING PAN-AFRICANISM: WEST INDIANS AND GOVERNANCE IN KWAME NKRUMAH'S GHANA}

Nicholas C. McLeod

August 3, 2020

After gaining independence from England, Kwame Nkrumah, the first President of Ghana, was transparent in his embrace of the entire African diaspora and actively recruited a number of Pan-African West Indian intellectual-activists, who mentored and advised him as a student in London, to help build Ghana as a Pan-Africanist state. Among these West Indian intellectual-activists were George Padmore, W. Arthur Lewis, T. Ras Makonnen, and Jan Carew. For these West Indians the appeal of Ghana was neither symbolic nor ceremonial, but rather an opportunity to achieve the ultimate objective of the Pan-African movement, a free and self-governed African continent.

In Ghana their Pan-Africanisms transcended its use as an ideology for political mobilization and consciousness and became praxis in governance as they contributing to the nation-building process of the first Sub-Saharan African nation to gain independence. In addition, examining the contrasting notions of diaspora, ethnicity, and identity that these West Indians encountered in Ghana, this dissertation illustrates that the West Indian influences on Kwame Nkrumah and Ghana were profound and critical to the nationbuilding process in the realms of political strategy, economics, institution building, and media. 
TABLE OF CONTENTS

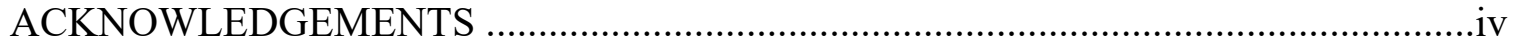

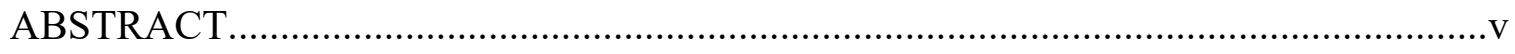

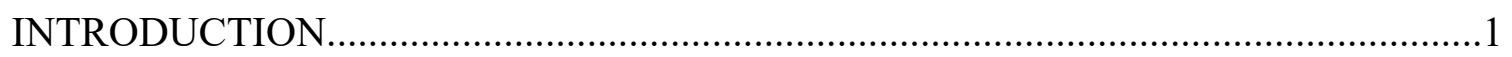

LONDON, PAN-AFRICANISM, AND THE SEEDS OF INDEPENDENCE...............31

GEORGE PADMORE, PAN-AFRICAN SOCIALISM, AND THE CONTOURS

OF AFRICAN NATIONALISM.................................................. 73

W. ARTHUR LEWIS, PAN-AFRICAN ECONOMICS, AND DEVELOPMENT

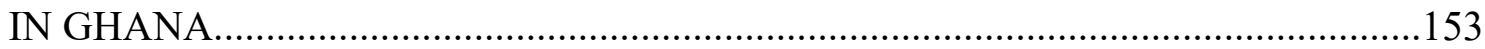

T. RAS MAKONNEN AND PRACTICAL PAN-AFRICAN IN

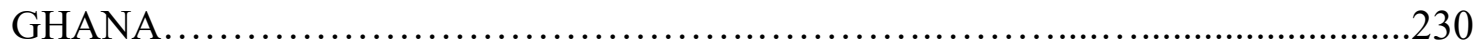

BLACK MIDAS AND GHANA'S BENEVOLENT DICTATOR ....................273

CONCLUSION: PAN-AFRICANISM AND PRAXIS............................................. 311

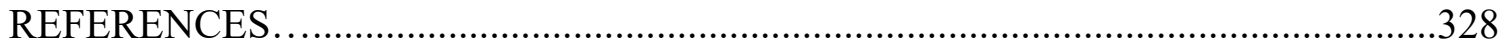

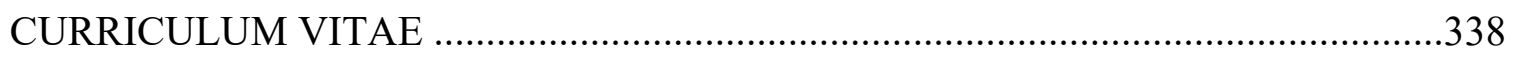




\section{INTRODUCTION}

As the interwar years came to a close in the mid-1940s, the world found itself in a state of transition. Europe had been brought to its knees by the World Wars and the United States and the Soviet Union had emerged as the leading world powers. The Black liberation struggle found itself in transition as well. By this time Black activists and intellectuals were migrating to Europe from the far reaches of European empires in the West Indies, Africa, and the United States. Unified by their common experiences of colonialism, racism, second class citizenship, and for many of them a socialist class analysis, these activist intellectuals developed a diasporic consciousness that would give way to the next phase of the Pan-African movement. All of this culminated in the 1945 Manchester Pan-African Conference, where for the first time African and West Indian attendees came together not as individuals but as delegates from organizations representing the masses of African workers, who determined that the colonial working classes must be the vanguard in the battle against imperialism. ${ }^{1}$

This generation, informed by their anti-colonial aspirations and a Pan-African consciousness then left the metropole to lead and participate in African liberation movements for independence in Africa and the West Indies. Many of these PanAfricanists made their way to Ghana in the years of the Gold Coast Revolution or following Independence to serve as advisors and officials in Kwame Nkrumah's

\footnotetext{
${ }^{1}$ Peter Olisanwuche Esedebe. Pan-Africanism: the Idea and Movement, 1776-1991. (Washington (D.C.): Howard University Press, 1994), 144.
} 
administration in hopes of building up Ghana to be the base of Pan-African liberation. Nkrumah was extremely transparent in his embrace of the entire African diaspora and realized that he and the people of Ghana needed a variety of skills to help build the nation. The new Prime Minister of Ghana did not sit and wait for volunteers to come, instead, he actively sought out who he believed to be the best individuals to assist, many of whom he had worked with during his activist years in London. Among these individuals were George Padmore, W. Arthur Lewis, T. Ras Makonnen, and Jan Carew. They all came with the desire to help build upon the foundations of the first Sub-Saharan African nation to gain independence in any way possible, with the ultimate goal of placing their Pan-Africanism into in order to free the African continent.

\section{Background and Arising Issues:}

As the first sub-Saharan African country to seize independence following the Second World War, Ghana occupies a prominent position within the histories of PanAfricanism. Its history, symbols, and leaders were latched onto by those in Africa and within the African Diaspora as a beacon of African redemption and the realization of a Pan-African dream. This dissertation analyzes the influence of West Indian intellectualactivists on Kwame Nkrumah and Ghana's first republic (1957-1966). Starting with the resurgence of the Pan-African movement prior to World War II and continuing through the post-independence era, this research explores the ideologies and skill sets that this select group of West Indians impressed upon Nkrumah and deployed in Ghana.

This dissertation furthers our understanding of Pan-Africanism and post-colonial politics by connecting African history to the growing scholarship concerning Black Internationalism. Winston James' Holding Aloft the Banner of Ethiopia (1998), 
demonstrates how West Indian activists helped shape both American and British radical movements of the early twentieth century, which raises the question of the place of Africa within these Black movements, which have always been transnational in nature. Furthermore, while scholars have produced several texts examining transnational exchanges and influences of African Americans, the dearth of West Indian and African collaboration in Black Internationalist discourses have become evident. Though recent works like Robert Trent Vinson's, The Americans Are Coming! and Kevin K. Gaines' African Americans in Ghana demonstrate how Diasporic movements often became intertwined with those in Africa, much work remains to be accomplished. As such, this dissertation places Ghana at its center, and builds on Africanist historiographies concerning African intellectuals, anti-colonialism, and nationalism, to emphasize how these West Indian intellectual activists' skills and ideas were received and implemented by Nkrumah and the Ghanaian nation-state.

Research Objectives and Hypothesis:

This dissertation internationalizes Ghana's independence movement, and it interrogates why Ghana, as a Pan-African project, was so significant and appealing to these West Indians who could have joined anti-colonial movements in their British Colonial homelands. Trinidadian intellectual George Padmore mentored Nkrumah and helped him conceptualize how a post-independent Ghana should theoretically operate. St. Lucian native and Nobel Laureate economist, W. Arthur Lewis, was sought after by Nkrumah to construct the plans for economic development in Ghana. Through the building of Pan-African institutions and the managing of the Ghanaian media, Guyanese intellectual activists, Ras Makonnen and Jan Carew sought to put Pan-Africanism into 
practice on the ground level for the Ghanaian masses. The fact that these individuals chose to contribute to Ghana's development when the decolonization efforts in the West Indies were gaining momentum speaks to Ghana's symbolic importance. This conveys not only to the power and magnetism that emanated from Ghana but also to its larger importance in global Pan-African circles. Furthermore, the fact that these intellectualactivists grew disenchanted with the Nkrumah regime also elucidates how Ghana's PanAfrican allure was limited.

The purpose of this dissertation is to examine the praxis of Pan-Africanism. Emphasizing the role of West Indian intellectual-activists in the advancement of PanAfricanism as an ideology and movement in the interwar years, as well as their vital role in placing the theory of Pan-Africanism into practice in governing and shaping Ghana. This is done by highlighting: (1) the roles of Padmore in influencing ideological and political trajectory of Kwame Nkrumah and governance in Ghana; (2) Lewis' influence on the design of Ghana's economic development plans; (3) Makonnen's role in overseeing of the building of state institutions in furtherance of Nkrumah's Pan-African Policy; and (4) Carew's contributions to Pan-African media outlets in Ghana and his advising of Nkrumah prior to being overthrown in February 1966. The dissertation also explores the ideologies and views that Padmore, Lewis, Makonnen, and Carew impressed upon Nkrumah and brought with them to Ghana. Making use of the memoirs, biographies, and authored texts of the West Indian intellectual-activists that migrated to Ghana following independence, their reasons for coming to Ghana; their struggles in Ghana; and their reflections on the meteoric rise and fall of the Nkrumah regime are examined. 
Situating the analysis of these intellectuals within the larger historical narrative of Ghana's first republic, this study ultimately contends that the West Indian influences and interactions with Kwame Nkrumah and Ghana, as a Pan-African project, were profound, lasting, and critical to the nation-building process in post-colonial Ghana. Furthermore, history requires a point of view that includes an interpretive form that contemplates the meaning of history. ${ }^{2}$ As such this dissertation produces an intellectual historical narrative that analyzes the socio-economic conditions and political context that prompted and resulted from the influences of the West Indian intellectual-activists.

\section{Significance:}

Whereas other studies have highlighted historical figures visiting, in dialogue with, or operating in activist capacities in transnational contexts, what sets this research project apart from other Black Internationalism scholarship is that not only it highlights the presence of West Indian intellectual-activists in Ghana, but also how and why they contributed to and directly shaped nation-building and governance. At a time when anticolonial and independence movements throughout the West Indies were furiously peaking, these West Indian intellectual-activists chose to relocate to West Africa and participate in the building of a Pan-African nation-state. For them, notions of a PanAfricanism and a global Africa, which included the entire African diaspora, was not simply an intellectual or philosophical exercise but a tangible one. For them, Ghana, not the West Indies, presented this possibility.

\footnotetext{
${ }^{2}$ Gaye Tuchman. " Historical Social Science: Methodologies, Methods, and Meanings," in The Sage Handbook of Qualitative Research, edited by Norman K. Denzin and Yvonna S. Lincoln. (Thousand Oaks, CA: Sage, 1994), 306.
} 
George Padmore, W. Arthur Lewis, T. Ras Makonnen, and Jan Carew constitute a continuation of the legacy of British West Indian intellectual-activists, such as William Finlason, Francis Grant, and T.E.S. Scholes, who contributed to the anti-colonial struggle in the Gold Coast in the nineteenth century. Unlike the majority of individuals discussed in Gaines' study, these intellectuals mentored Nkrumah during his time as a student in London and were actively recruited to work in the Ghanaian government. As a result, they found themselves in coveted positions, having direct access to Nkrumah, with the ability to influence Ghana's nation-building process in the realms of political philosophy, economic development, Pan-African institutions, and media. Thus, the ideologies, immediate reactions, and reflections on the social conditions of the nation and the ideological direction of Nkrumah's administration are vital components that have yet to be adequately discussed in Ghana's historical narrative.

\section{Historiography}

Post-Colonial African History:

The historical impact of colonialism and decolonization manifested in the rise of the Nationalist school of history in which historians like Ali Mazrui, Cheikh Anta Diop, and Basil Davidson sought to refute the notion that Africans never had a "real history" of their own by highlighting the achievements and integrity of pre-colonial African cultures and civilizations. ${ }^{3}$ These historians sought to differentiate themselves from the "imperial

\footnotetext{
${ }^{3}$ Chancellor Williams. The Destruction of Black Civilization: Great Issues of a Race from 4500 BC to 2000 AD. (Chicago: Third World Press, 1987); Martin Bernal. Black Athena: Afroasiatic Roots of Classical Civilization, Volume I: The Fabrication of Ancient Greece, 1785-1985. (New Brunswick: Rutgers University Press, 1987); Cheikh Anta Diop. Civilization or Barbarism. (Chicago: Chicago Review Press, 1991); Diop, Cheikh Anta. The African Origin of Civilization: Myth or Reality. (Chicago: Chicago Review Press, 1989); Jackson, John G. Introduction to African Civilizations. (Mansfield Centre, CT : Martino Publishing, 2015)
} 
historians" of the past. ${ }^{4}$ The most prolific of these scholars was Guyanese historian Walter Rodney, whose seminal text, How Europe Underdeveloped Africa remains to this day as an example of impeccable scholarly research. In an age when historians were researching slavery, pre-colonial Africa, and reclaiming ancient Kemet, it was Walter Rodney who turned our attention back to colonialism, capitalism, and Europe's role in underdeveloping Africa, politically, socially, and culturally. As European scholars were placing the blame of Africa's underdevelopment on the stereotypical inferiority and primitive nature of Africans, Rodney asserted that the true explanation lay in understanding the relationship of exploitation between Africa and the developed capitalist nations of Europe. ${ }^{5}$ Employing a historical materialist method, Rodney's scientific approach to studying the historical impact of colonialism reminded historians that the only positive aspect of colonialism was decolonization.

Historians of Africa also began to center the experiences of Africans themselves in their constructions of African historical narratives. In his text African Perspectives on Colonialism, Adu Boahen emphasized the necessity of referencing African sources and knowledge systems by arguing that African historians must deliver historical portrayals of African colonialism from the perspective of Africans, as opposed to the common practice of historians merely providing histories of Europe in Africa. In doing so, historians began to examine the complex African ideologies, institutions, and political processes that mobilized anti-colonial movements. ${ }^{6}$ In his pioneering text, Nationalism

${ }^{4} \mathrm{~K}$. Onwuka Dike, Trade and Politics in the Niger Delta 1830-1885: An Introduction to the Economic and Political History of Nigeria (Oxford: Oxford University Press, 1956) and Frederick Cooper. "Conflict and Connection: Rethinking Colonial African History." The American Historical Review 99, no. 5 (1994): 1516-1545.

${ }^{5}$ Rodney. How Europe Underdeveloped Africa. (Dar es Salaam: Tanzania Publishing House, 1972), 14.

${ }^{6}$ J. F. Ade Ajayi, “ The Continuity of African Institutions under Colonialism," in Emerging 
in Colonial Africa Thomas Hodgkin stressed the necessity of studying African political institutions in the same fashion as British, French, and American institutions. For Hodgkin African nationalism needed to be approached as a historical movement that is necessary and characteristically African. Building upon this were studies like Toyin Falola's Nationalism and African Intellectuals, which illustrates how processes of construction and reproduction of African nationalist thought shaped the production of knowledge and politics in Africa since the nineteenth century. Pairing biographical accounts of key African intellectuals with their relationships to missionaries; colonial powers; state formations; and African nationalism, Falola examines the varying intellectual orientations of key figures of African nationalist movements. ${ }^{7}$

A common thread among these studies of post-colonial Africa is the prominent role of Kwame Nkrumah and Ghana. Basil Davidson and Trevor Jones were early contributors to the historiography of Ghana's independence. ${ }^{8}$ Their texts provided the foundation for the monotonous meteoric rise and fall frameworks that shaped Ghana's post-colonial history for decades. In recent times historians began to study Africa with socio-historical methodologies, which required them to situate their studies in larger global or social contexts. Social histories also allowed for societies in Africa to be studied from several different vantage points beyond the general European and African

Themes in African History, edited by Terence O. Ranger (London: Heinemann Educational, 1968), 189200; Basil Davidson. The Liberation of Guinea: Aspects of an African Revolution. (Harmondsworth, Penguin, 1969); Ali Mazrui, Kwame Nkrumah, and A. A. Afrifa. "Towards a Pax Africana." Science and Society 33, 1 (1969), 101-104.

${ }^{7}$ Toyin Falola. Nationalism and African Intellectuals. (New York: University Rochester Press, 2001)

${ }^{8}$ Basil Davidson. Black Star: A View of the Life and Times of Kwame Nkrumah. (New York: Praeger, 1974); Trevor Jones. Ghana's First Republic 1960-1966: The Pursuit of The Political Kingdom. (London: Methuen \& Co Ltd, 1976) 
perspectives of previous scholarship. ${ }^{9}$ This approach allowed for more studies of the intersections of newly formed nation-states, identity, nationalism, and ethnicity to emerge. ${ }^{10}$ Instead of confining their historical narratives to colonial officials and prominent anti-colonial agitators, studies like Jean Allman's The Quills of the Porcupine, Richard Rathbone's Nkrumah \& the Chiefs, and Jeffrey Ahlman's Living Nkrumahism began to highlight under-discussed conditions of decolonization, namely that anticolonial movements were not always monolithic and united, but were rather fragmented with several groups vying for their political interests to be prioritized.

\section{Global Africa:}

While social history approaches have greatly expanded the scope of how Africa's history is constructed, in recent decades African history has taken not only a transnational but a transoceanic turn. Building on the pioneering works of historians like John Thornton, David Northrup, A.G. Hopkins, and Joseph E. Inikori, Africanists began to read more widely on both Africa and its diaspora, to explore comparisons and linkages within the African continent and with the diaspora, to draw on evidence from the African

\footnotetext{
${ }^{9}$ Emmanuel Akyeampong. Drink, Power, and Cultural Change: A Social History of Alcohol in Ghana, c. 1800 to Recent Times. (Portsmouth, NH: Heinemann, 1996); Emmanuel Akyeampong. Between the Sea and the Lagoon: An Eco-Social History of the Anlo of Southeastern Ghana, c. 1850 to Recent Times. (Athens: Ohio University Press, 2001); Benjamin Talton. Politics of Social Change in Ghana. (New York: Palgrave Macmillan, 2010); and Ray, Carina E. Crossing the Color Line: Race, Sex, and the Contested Politics of Colonialism in Ghana. (Athens: Ohio University Press, 2015)

${ }^{10}$ Jean Marie Allman. The Quills of the Porcupine: Asante Nationalism in an Emergent Ghana. (Madison: University of Wisconsin Press, 1993); I. Tashjian, and Jean Allman. 'I Will Not Eat Stone. 'A Women's History of Colonial Asante. (Portsmouth, NH: Heinemann, 2000); Richard Rathbone. Nkrumah \& the Chiefs: the Politics of Chieftaincy in Ghana, 1951-60. (Athens: Ohio State University Press, 2000); Kelly Askew. Performing the Nation: Swahili music and Cultural Politics in Tanzania. (Chicago: University of Chicago Press, 2002); Leroy Vail. ed. The Creation of Tribalism in Southern Africa. (Oakland, CA: University of California Press, 1991); Terence Ranger. " The Invention of Tradition in Colonial Africa." in Perspectives on Africa: A

Reader in Culture, History, and Representation, edited by Roy Richard Grinker and Christopher B. Steiner. (Oxford: Blackwell, 1997) 597-612; Luise White. The Comforts of Home: Prostitution in Colonial Nairobi. (Chicago, IL: University of Chicago Press, 2009)
} 
diaspora to answer questions about the homeland and to write for audiences beyond other Africanists. ${ }^{11}$ Furthermore, while this shift to the diaspora is a recent occurrence in approaches to African history, globally historians of African descent had already been diligently constructing the history of a global Africa.

In his article, “'But a Local Phase of a World Problem’: Black History’s Global Vision, 1883-1950.," historian Robin D. G. Kelley, recalls his astonishment in discovering the extent to which Black scholars, in the late nineteenth and early twentieth century, were constructing transnational histories that examined the international contexts in which people of African descent have operated. ${ }^{12}$ Indeed for nearly two centuries historians of various levels of training produced transnational and comparative scholarship on issues of slavery, citizenship, Black intellectual traditions, the dangers of American nationalism, imperialism, modernity, and identifying with "a larger black world in which New World Negroes were inheritors of African as well as European civilizations." 13 In doing so, these scholars were conducting research from a transnational perspective and conceiving of an "African Diaspora."

The term "African diaspora" was coined by George Shepperson and Joseph E. Harris at the 1965 meeting of the International Congress of African Historians in

\footnotetext{
${ }^{11}$ John Thornton. Africa and Africans in the Making of the Atlantic World, 1400-1800. (Cambridge University Press, 1998); David Northrup. Africa's Discovery of Europe. (Oxford: Oxford University Press, 2013); Joseph E. Inikori, Africans and The Industrial Revolution In England: A Study In International Trade and Economic Development. (Cambridge: Cambridge University Press, 2002); Patrick Manning. "Africa and the African Diaspora: New Directions of Study." Journal of African History, 44 (2003), 488.

12 Robin D. G. Kelley. “'But a Local Phase of a World Problem': Black History’s Global Vision, 18831950." The Journal of American History, Vol. 86, No. 3, The Nation and Beyond: Transnational Perspectives on United States History: A Special Issue (Dec., 1999), 1046; Vincent Carretta, ed., Unchained Voices: An Anthology of Black Authors in the English-Speaking World of the Eighteenth Century (Lexington: University Press of Kentucky, 2013); Adam Potkay and Sandra Burr, eds., Black Atlantic Writers of the 18th Century. (New York: Palgrave Macmillan, 1995)

13 Kelley. "But a Local Phase of a World Problem,", 1050.
} 
Tanzania. ${ }^{14}$ Historian, Patrick Manning suggests that "The 'African Diaspora', as an object of study, centers on populations descended from and at a distance from populations of the 'African continent' or 'African homeland'." 15 While initial research emphasized historically created populations rather than racial essences or regional continuities, the study of political, social and cultural connections among these population emerged. ${ }^{16}$

Historical research on the African diaspora produced studies including migrations of free Africans in many eras; slave trade; slavery and emancipation; migratory patterns; the formation and retaining of cultures among African peoples in the diaspora; precolonial and colonial society on the African continent; and the impact of colonialism in Africa. ${ }^{17}$ Typically framed by racial paradigms of the west, racial essentialism became integral to transnational histories of the African diaspora, thus giving rise to philosophies of Afrocentricity, nationalist historians, and new methodological approaches to constructing historical research. ${ }^{18}$ Additionally, the emergence of Pan-Africanism discourses added a political agenda to African diaspora histories, as more global thinking

\footnotetext{
${ }^{14}$ Kim D. Butler. "Clio and the Griot: the African Diaspora in the Discipline of History." in The African Diaspora and the Disciplines, edited by Tejumola Olaniyan and James H. Sweet. (Bloomington: Indiana University Press, 2010), 23.

${ }^{15}$ Manning. "Africa and the African Diaspora: New Directions of Study.” (2003); Edna G. Bay, and Kristin Mann, eds. Rethinking the African Diaspora: The Making of a Black Atlantic World in the Bight of Benin and Brazil. (London: Routledge, 2013); Okpewho, Isidore, Carole Boyce Davies, and Ali Al'Amin Mazrui, eds. The African Diaspora: African Origins and New World Identities. (Bloomington: Indiana University Press, 2001)

${ }^{16}$ Manning. "Africa And The African Diaspora: New Directions Of Study," (2003), 490.

${ }^{17}$ Ben Vinson III. "Introduction: African (Black) Diaspora History, Latin American History." The Americas 63, no. 1 (2006): 1-18), 3.; Kwame Essien. Brazilian-African Diaspora in Ghana: The Tabom, Slavery, Dissonance of Memory, Identity, and Locating Home. (East Lansing : Michigan State University Press, 2016)

${ }^{18}$ Molefi K. Asante. Afrocentricity: The Theory of Social Change. (Chicago, IL: African American Images, 2003); Ivan Van Sertima. They Came Before Columbus. (New York: Random House 1976); John Henrik Clarke. "African-American Historians and the Reclaiming of African History." Présence Africaine 2 (1979), 29-48.
} 
spurred interest in interrelated histories, ongoing relationships, and shared concerns. The most recent iteration of African Diaspora history has emerged in the discourse on Black Internationalism. Such is the tradition of scholarship and research that this dissertation is located within.

\section{Defining Black Internationalism:}

From the days of George Washington Williams in the later nineteenth century, historians of Black history have sought to place Black history in a global context. Whether they were countering the scientific racism, reconstructing a glorious African past, or trying to contribute to the formation of a collective identity of "peoplehood" based on blackness, these historians always wrote in direct opposition to European imperialism. James T. Campbell's text Middle Passages demonstrates that notions of a “Black Internationalism" or "Black Internationalist consciousness" were not first conceived of by contemporary scholars of history. Campbell uses the lives of prominent African American male figures such as Martin Delany, Bishop Henry McNeil Turner, and W.E.B. Dubois to explore the positioning of the African continent as the homeland and epicenter of racial identity for African Americans in the later nineteenth and early twentieth centuries.

The early twentieth century gave way to the largest mobilization of Pan-African resistance the African diaspora has ever seen. During this time Blacks in Harlem were identifying with their counterparts in London, Ethiopia, Havana, and Paris, as their collective struggles began to be viewed in international contexts. ${ }^{19}$ This notion of Black

\footnotetext{
${ }^{19}$ Marc Matera. Black London: The Imperial Metropolis and Decolonization in The Twentieth Century. (Oakland, CA: University of California Press, 2015); Gilroy, Paul. There Ain't No Black in the

Union Jack. (London: Routledge, 2013); Bill Schwarz. West Indian Intellectuals in Britain. (Manchester:
} 
experiences, cultures, and identities transcending the national boundaries laid by

European imperialist reflected a Black Internationalist consciousness among the Black

masses. Although it cannot be denied that Pan-Africanism and nationalism were at the foundations of several Black and African movements of the twentieth century, scholars have begun to recognize that in order for Pan-Africanism, collective Black identities, or even the concept of an African diaspora to be articulated, its adherents must possess a Black Internationalist consciousness. As a result, contemporary historians have acknowledged Black Internationalism as a vital characteristic of Black radicalism, PanAfricanism, Anti-Colonialism, and even the Civil Rights movement. ${ }^{20}$

Political theorist, Carl Schmitt defines "true" internationalism as "international movements which transcend the borders of states and ignore the territorial integrity, impenetrability, and impermeability of existing states"21 Furthermore, in addition to being a political philosophy, radical epistemology, and institutional practice that functions not only to establish linkages between different Black populations, Caribbean scholar, Michelle Stephens suggests that Black Internationalism is a desire for racial

Manchester University Press, 2003), 153; Hakim Adi. West Africans in Britain 1900-1960: Nationalism, Pan-Africanism and Communism. (London: Lawrence \& Wishart, 1997); Minkah Makalani. In the Cause of Freedom: Radical Black Internationalism from Harlem to London, 1917-1939. (Chapel Hill: University of North Carolina Press, 2011); Hakim Adi. Pan-Africanism and Communism: The Communist International, Africa and the Diaspora, 1919-1939. (Trenton, NJ: Africa World Press, 2013); Félix F. Germain. Decolonizing the Republic: African and Caribbean Migrants in Postwar Paris, 1946-1974. (Lansing: Michigan State University Press, 2016); T. Denean Sharpley-Whiting. Bricktop's Paris: African American Women in Paris between the Two World Wars. (Albany, NY: Suny Press, 2015); Hayes Edwards. The Practice Of Diaspora: Literature, Translation, and the Rise of Black Internationalism. (Cambridge: Harvard University Press, 2009); Reiland Rabaka. The Negritude Movement: WEB Du Bois, Leon Damas, Aime Cesaire, Leopold Senghor, Frantz Fanon, and the Evolution of an Insurgent Idea. (Lanham, Maryland: Lexington Books, 2015)

${ }^{20}$ Nicholas Grant. Winning Our Freedoms Together: African Americans and Apartheid, 1945-1960. (Chapel Hill: University of North Carolina Press, 2017); Imaobong D. Umoren. Race Women Internationalists: Activist-Intellectuals and Global Freedom Struggles. (Oakland, CA: University of California Press, 2018); Anne Garland Mahler. From the Tricontinental to the Global South: Race, Radicalism, and Transnational Solidarity. (Durham: Duke University Press, 2018)

${ }^{21}$ Carl Schmitt. The Concept of the Political: Expanded Edition. (Chicago: University of Chicago Press, 2008), 55-56. 
freedom and unity stemmed from Black subjects findings themselves asking deeper structural questions of the political world around them. ${ }^{22}$ As such, Black Internationalism questions not only how blacks can create linkages within the race but also what systems and forces that divided and created the African diaspora in the first place. Ultimately, Black Internationalism analyzes racial subordination as a part of systems that function on a supranational scale and requires communication and the formation of alliances across political and national boundaries. ${ }^{23}$

\section{Launching a Black Internationalism Discourse:}

Scholars have been conducting transnational research on Black intellectuals' use of Pan Africanism as an anti-colonial project through the theoretical framework of Black Internationalism decades. In recent scholarship, the Black Internationalist analysis of the African Diaspora was launched by Paul Gilroy's text, The Black Atlantic, which to reexamines the problems of nationality, authenticity, ethnicity, and historical memory through a transnational and intercultural lens to understand the modern Black experience. Michael O. West's From Toussaint to Tupac was the first study that explicitly focused on the concept of Black Internationalism, in which it is defined as the consciousness of the interconnection of Black struggles across man-made boundaries. West's text also makes clear is that the discourse on Black Internationalism projects a peculiar reflection of the implications of European imperialism and modernity, as the scholarship has organically

\footnotetext{
${ }^{22}$ Michelle Stephens. "Disarticulating Black Internationalisms: West Indian Radicals and The Practice of Diaspora." Small Axe 9, no. 1. (2005), 104.

${ }^{23}$ Lara Putnam. Radical Moves: Caribbean Migrants and the Politics of Race in the Jazz Age. (Chapel Hill: University of North Carolina Press, 2013), 6.
} 
progressed into analyses of the transnational Pan-Africanist relationships that manifested and fostered particularly in the twentieth century anti-colonial struggles and resistance.

One of the most popular assessments of Black Internationalism is the typical analysis of the linkages between African American social movements and the anticolonial struggles in the West Indies and in Africa. Historians like Penny Von Eschen and Brenda Gayle Plumber sought to refute the notion that African Americans remained preoccupied with the domestic civil rights struggle and possessed a limited interest in foreign affairs. They highlighted African American responses to events such as the Italian Invasion of Ethiopia, the Pan-African Congress movement; the efforts of the Leninist influenced Council on African Affairs (CAA) led by Paul Robeson; the Bandung conference, and fluctuating desire to be associated with Africa among African Americans. ${ }^{24}$ These texts illustrate Pan-African linkages in how Africans Americans internationalized the conversation on racism and anti-colonialism in order to augment the Black freedom struggle in the United States. ${ }^{25}$

\section{Black Internationalism and the West Indies:}

Black internationalist scholarship could not overlook the significance of the West Indies blacks to twentieth-century social movements. ${ }^{26}$ Winston James' Holding Aloft

\footnotetext{
${ }^{24}$ Brenda Gayle Plummer. Rising Wind: Black Americans and US Foreign Affairs, 1935-1960. (Chapel Hill: University of North Carolina Press, 1996); Brenda Gayle Plummer. In Search of Power: African Americans in the Era of Decolonization, 1956-1974. (Cambridge: Cambridge University Press, 2013); Penny M. Von Eschen. Race Against Empire: Black Americans and Anticolonialism, 1937-1957. (Ithaca, New York: Cornell University Press, 1997); James Hunter Meriwether. Proudly We Can Be Africans: Black Americans and Africa, 1935-1961. (Chapel Hill: University of North Carolina Press, 2002); Joseph E. Harris. African-American Reactions to War in Ethiopia, 1936-1941. (Baton Rouge: Louisiana State University Press, 1994)

${ }^{25}$ John Munro. The Anticolonial Front: The African American Freedom Struggle and Global Decolonization, 1945-1960. (Cambridge: Cambridge University Press, 2017)

${ }^{26}$ James Davis. Eric Walrond: A Life in the Harlem Renaissance and the Transatlantic Caribbean. (New York: Columbia University Press, 2015); Michelle Ann Stephens. Black Empire. (Durham: Duke University Press, 2005); Tony Martin. The Pan-African Connection: From Slavery to Garvey and Beyond.
} 
the Banner of Ethiopia, attempts to remedy the erasure of the West Indies and West Indians in Black Internationalist discourse by assessing the causes of the widespread involvement of West Indian figures in the Black radical movement in the United States during the early twentieth century. Filling the void left in Gilroy's analysis of the Black Atlantic, James ultimately concludes that the West Indian presence in radical American social movements resulted from West Indian peoples' prior experience in radical politics in their home countries; their racial majority status within West Indian societies; and their shared feeling of educational and cultural superiority to their white tormentors.

Considering the United States' position as the dominant world power in the western hemisphere, scholars began to examine transnational solidarities and cooperation between Black West Indians and African Americans. ${ }^{27}$ Frank Andre Guridy's Forging Diaspora: Afro-Cuban and African Americans highlights the centrality of these crossnational linkages and ultimately demonstrates that Afro-Cubans viewed the issue of racial inequality not as simply a national question but also as one that pertained to themselves and African Americans as members of a collective transnational colored race. ${ }^{28}$ Demonstrating the influence of the West Indies on American politics is Lara Putnam's Radical Moves, in which the experiences of Black West Indian migrant workers as they formed transnational identities and networks throughout the West Indies, Latin America,

(Dover, Mass.: The Majority Press, 1984); Mark Solomon. The Cry Was Unity: Communists and African Americans, 1917-1936. (Jackson: University Press of Mississippi, 1998); Joyce Moore Turner and W. Burghardt Turner. Caribbean Crusaders and the Harlem Renaissance. (Urbana: University of Illinois Press, 2005)

${ }^{27}$ Millery Polyné. From Douglass to Duvalier: US African Americans, Haiti, and Pan Americanism, 18701964. (Gainesville: University Press of Florida, 2010)

${ }^{28}$ Frank Andre Guridy. Forging Diaspora: Afro-Cubans and African Americans in a World of Empire and Jim Crow. (Chapel Hill: University of North Carolina Press, 2010) 
and the United States, and shaped immigration policy the United Stated in the early twentieth century. ${ }^{29}$

\section{Black Internationalism and Africa:}

Studies of Black Internationalism have only recently begun to engage the African continent. ${ }^{30}$ One of the ways scholars have approached this topic has been through tracking how ideologies and philosophies from the diaspora have traveled to and influenced the African continent. Andrew Zimmerman's Alabama in Africa demonstrates a peculiar moment of intersection between Booker T. Washington's Tuskegee philosophy, the German colonization of Togo, arguing that Tuskegee's industrial education "became a veritable orthodoxy of colonial administration and international humanitarianism."31 Washington's Tuskegee philosophy sought to equip impoverished blacks with the principle and trade skills for economic self-determination and independence, which is why it's principles were embraced throughout Africa and served as a call to action for Marcus Garvey.

The massive influence of Marcus Garvey on the African continent is highlighted in the work of Robert Trent Vinson and Adam Ewing. ${ }^{32}$ Vinson's The Americans Are Coming!: Dreams of African-American Liberation in Segregationist South Africa,

\footnotetext{
${ }^{29}$ Lara Putnam. Radical Moves: Caribbean Migrants and the Politics of Race in the Jazz Age. (Chapel Hill: University of North Carolina Press, 2013)

${ }^{30}$ Seth. Markle. A Motorcycle on Hell Run: Tanzania, Black Power, and the Uncertain Future of PanAfricanism, 1964-1974. (East Lansing: University of Michigan Press, 2017); Ira Dworkin. Congo Love Song: African American Culture and the Crisis of the Colonial State. (Chapel Hill: University of North Carolina Press, 2017); and Nicholas Grant. Winning Our Freedoms Together: African Americans and Apartheid, 1945-1960. (Chapel Hill: University of North Carolina Press, 2017)

${ }^{31}$ Andrew Zimmerman. Alabama in Africa: Booker T. Washington, the German Empire, and the Globalization of the New South. (Princeton: Princeton University Press, 2010), 204.

${ }^{32}$ R.T. Vinson. The Americans are Coming!: Dreams of African American Liberation in Segregationist South Africa. (Athens: Ohio University Press, 2012); Adam Ewing. The Age of Garvey: How a Jamaican Activist Created a Mass Movement and Changed Global Black Politics. (Princeton: Princeton University Press, 2016)
} 
examines Garveyism in South Africa and the prominent idea that Garveyism prophesied that the UNIA and American Blacks were divinely ordained to regenerate Africa. The influence of Garvey on Africa is broadened by Adam Ewing's The Age of Garvey, which posits Garveyism not as an ideology but as a method for organic mass politics that manifests as a coherent and malleable set of liberation strategies that were applied to local struggles in Liberia, Nigeria, Gold Coast, South Africa, and Kenya. These texts set themselves apart in the discourse, as they demonstrate how prominent figures and Black political consciousness traverse national borders, and that ideologies traveled and were applied to localized conditions as well.

The second approach to studies of Black Internationalism in Africa has explored the history of returnees and expatriates from the African diaspora. Nemata Amelia Blyden's West Indians in West Africa 1808-1880: The African Diaspora in Reverse, initiated the recent exploration of West Indian returnees to the African continent. ${ }^{33}$ Themes of memory, cultural retention, anti-colonialism, and the reverse migrations of formerly enslaved Africans, the Tabom, were examined in Kwame Essien's BrazilianAfrican Diaspora in Ghana: The Tabom, Slavery, Dissonance of Memory, Identity, and Locating Home. Charting the retention of the Tabom's own cultural identity as well as their participation in and influence on the social, political, and cultural framework of colonial and post-colonial Ghana, Essien's text furthers the discourse on the challenges and complexities of diaspora, ethnicity, and identity that returnees brought with them and encountered in Africa. ${ }^{34}$ These themes of the reverse migrations to the African continent

\footnotetext{
${ }^{33}$ Nemata Amelia Blyden. West Indians in West Africa, 1808-1880: The African Diaspora in Reverse. (Rochester, NY: University of Rochester Press, 2000)

${ }^{34}$ Kwame Essien. Brazilian-African Diaspora in Ghana: The Tabom, Slavery, Dissonance of Memory, Identity, and Locating Home. (East Lansing : Michigan State University Press, 2016)
} 
have been furthered Kevin K. Gaines, Seth M. Markle and more recently Monique A. Bedassee, as the challenges and complexities of cultural identity, diaspora, ethnicity, and belonging that returnees brought with them and encountered in Africa are highlighted. ${ }^{35}$

Issues in Black Internationalist Historiography:

The histories of Pan-African anti-colonial projects are well traversed, especially in the recent rise of Black Internationalist scholarship. The goals of the anti-colonial movements and transnational solidarities of the interwar years were aimed at decolonization and independence with the goal of freeing and restoring Africa to join the rest of the modern nations of the world. Furthermore, Ira Dworkin's Congo Love Song: African American Culture and the Crisis of the Colonial State and Nicholas Grant's Winning Our Freedoms Together: African Americans and Apartheid, 1945-1960 reflect new scholarship on the historical experiences and relationships fostered between African Americans, the rest of the diaspora and the African continent. However, the scholarship has done little to advance understandings of Pan-Africanism beyond its use as a mobilizing ideology of solidarity for anti-colonialism, as Pan-Africanism is routinely characterized as a movement of the early twentieth century, dominated by the personalities of Marcus Garvey and W.E.B. Dubois. Furthermore, the discourse on the dialogues, ideologies, and identities traversing national boundaries between Africa and the West Indies through the prism of Pan-Africanism is still in its infancy.

\footnotetext{
${ }^{35}$ Kevin K. Gaines. American Africans in Ghana: Black expatriates and the Civil Rights Era. (Chapel Hill: University of North Carolina Press, 2012); Markle. A Motorcycle on Hell Run: (2017); Monique A. Bedasse. Jah Kingdom: Rastafarians, Tanzania, and Pan-Africanism in the Age of Decolonization. (Chapel Hill: University of North Carolina Press, 2017) For more on this see: Angelou, Maya. All God's Children Need Traveling Shoes. (London: Vintage, 2010)
} 
The majority of studies of Black Internationalism have sought to place Black history and identity in a global context, and there are several observations to be noted. Winston James was correct in his argument that radicalized West Indians were at the center of many of the Black social movements of the twentieth century, as there is no shortage of West Indian historical figures within the discourse. Still, the discourse has confined the West Indian presence to the Americas, Harlem, and Europe. Only recently, has it endeavored to examine the West Indian presence in Africa. Also, Black Internationalist scholars have yet to sufficiently interrogate the concept of Diaspora and its nuances, particularly in terms of the racial essentialism and difference. While essentialism is necessary to a certain extent in articulating diasporas, the differences that emerge from varying historical experiences, social structures, migrations, languages, and cultures must also be explored in our analyses of the African diaspora.

While issues of racism, colonial resistance, migration, and transnational networks have been explored, Black Internationalist scholarship has yet to consider the difficulties people of African descent faced in governance after gaining independence. The nationbuilding process presents several conditions and challenges that Black Internationalist discourses have not engaged, such as the historical discourse on nations, nationalism, tribalism, and ethnicity. Furthermore, where the Black Internationalist scholarship finds its shortcomings, Africanist scholars have begun highlighting these difficulties in postcolonial histories. Scholars such as Leroy Vail and Kelly M. Askew have pushed back against the Eurocentrism of Benedict Anderson's Imagined Communities, which excludes conditions in Africa in its contention that nationalism is both a singular phenomenon and 
a cultural artifact, and also positions print media as the primary catalyst to developing national consciousness in the modern era. ${ }^{36}$

In addition to the struggles of nation-making and nationalism, is the issue of PanAfricanism clashing with African Nationalism in post-colonial African states. Prior to independence, African nationalism was less about establishing shared identities and belongingness. Instead, the sole ideology of African nationalism was anti-imperialism. Following independence Ghanaian elites came to view these West Indians as direct competition rather than their brothers and sisters that returned to aid in building the nation. As a result, Nkrumah found himself in a compromising position, between satisfying his countrymen and his diaspora kinsmen, which caused his loyalties to be questioned at times. This conundrum presents an opportunity to engage notions of sameness and difference as it relates to the articulating, sustaining, and even dissolving of the diaspora. This is vital to this study of Ghana as the Ghanaian citizenry did not always agree with the Pan-African aspirations of Nkrumah and or the presence of the West Indian intellectual-activists he recruited.

As such, the discourse is ripe for the study of Black Internationalism that interrogates the intersecting conditions, interactions, and ideological exchanges between African and the West Indian intellectual-activists that led the Pan-African movements in the diaspora and contributed to African liberation on the continent. Additionally, considering the larger Pan-African project that was Kwame Nkrumah's Ghana, the Black Internationalism discourse has yet to furnish an in-depth analysis of the ideologies,

\footnotetext{
${ }^{36}$ Vail. The Creation of Tribalism in Southern Africa. (1991); Askew. Performing the Nation: Swahili Music and Cultural Politics in Tanzania. (2002); and Benedict Anderson. Imagined Communities: Reflections on the Origin and Spread of Nationalism. (London: Verso Books, 2006)
} 
influences, and contributions of West Indian intellectual-activists in the first sub-Saharan African nation to gain its independence.

This dissertation demonstrates that Pan-Africanism and its use to mobilize Africa and the African Diaspora proved to be an effective anti-colonial political ideology. Without question, Pan-Africanism was embraced and demonstrated from Trinidad - the nation from which Pan-Africanism emanated from the beginning of the twentieth century -; to Black Communist internationalists in Cuba; and to radical Black feminist internationalism in post-World War Two London. ${ }^{37}$ Through these networks of intellectualism and activism, Pan-Africanism was placed at the center of all analyses of the globalized European imperialist social structure. However, once independence was achieved, and as these intellectual-activists left the metropoles for independent nations, the dubious relevance, pragmatism, and necessity of Pan-Africanism in nation-building processes revealed the ideology's varying conceptions and manifestations, as well as its shortcomings. My dissertation moves beyond the use of Pan-Africanism as a mobilizing ideology for anti-colonial resistance and revolt and places emphasis on how West Indian intellectual-activists - George Padmore, W. Arthur Lewis, T. Ras Makonnen, and Jan Carew - placed Pan-Africanism into practice for the next phase of the movement, governance in post-colonial Ghana.

\footnotetext{
${ }^{37}$ Margaret Stevens. Red International and Black Caribbean: Communists in New York City, Mexico and the West Indies, 1919-1939. (Chicago: University of Chicago Press, 2017); and Carole Boyce Davies. Left of Karl Marx: The Political Life of Black Communist Claudia Jones. (Durham: Duke University Press, 2007)
} 


\section{Methodology}

\section{Conceptual Framework:}

Historians have examined Pan-Africanism through its assessments of its proponents, as a movement, ideology, or as a consciousness focusing particularly on the potential of its outcomes. In the case of Ghana and Nkrumah, studies of Pan-Africanism are typically limited to Nkrumah's contributions to promoting the ideology and rhetoric linking Ghana's independence to the rest of the continent. Still very little has explored the various ways in which Pan-Africanism was placed into praxis in governance, which was the ultimate goal of the Pan-African movement. Examining Ghana as a continuation of the Pan-African movement this dissertation uses an Afro-West Indian epistemological standpoint and historical methods to conduct a socio-historical analysis of governance and Pan-Africanism in Ghana. Using this Afro-West Indian epistemological standpoint, Ghana's nation-building process is examined through the perspectives and experiences of these West Indian intellectual-activists recruited by Nkrumah to work in Ghana.

This West Indian epistemological framework builds upon James E. Turner's concept of Africana epistemological frameworks, which produces more accurate findings, understandings, and conclusions about the socio-cultural and politico-economic realities of African descended. ${ }^{38}$ Furthermore, Serie McDougal's assumptions of the Africana epistemological paradigm: the experiences of people of African descent are worthy of study; African people have unique and distinctive cultural and historical experiences; the best way to understand African people is from their own perspectives;

\footnotetext{
${ }^{38}$ James E. Turner. "Africana Studies and Epistemology: A Discourse in the Sociology of Knowledge." in Africana Studies: A Disciplinary Quest for Both Theory and Method, edited by James L. Conyers, Jr. (Jefferson, N.C.: McFarland \& Company, 1997), viii.
} 
people's world views determine what constitutes a problem for them and how they approach solving them; the fundamental substance of all reality is spirit; and that the ultimate goal of Africana studies must be the empowerment and liberation of people of African descent, are specifically applied to the experiences of West Indians working in the Ghanaian government following independence. ${ }^{39}$ As such, this Afro-West Indian epistemological frame of reference places the Afro-West Indian experience at the center of this dissertation in order to conduct research that emanates from the perceptions and experiences of the West Indian intellectual-activists being examined.

\section{Methods:}

Methodologically this dissertation merges three historiographies including African History, Caribbean History, and the now robust historiography of Black Internationalism. The African historiography is privileged because this project is a study of West Indian intellectual-activists in Ghana's independence and nation-building process. These intellectuals, all from the British West Indies, are examined in the context of their experiences in Ghana. Furthermore, while there is a strong political component to the project, it is also a social history. The social history component is found in the examination and analysis of the social factors behind many of the opinions, assumptions, and worldviews that these intellectuals brought with them to Ghana. This includes the socio-historical, political, and cultural contexts that influenced their own ideologies, lifestyles, and decisions to travel to Ghana. Additionally, the socio-cultural conditions in Ghanaian society that contributed to the assumptions, perspectives, and reactions of

\footnotetext{
${ }^{39}$ Serie McDougal. Research Methods in Africana Studies. (New York, NY: Peter Lang, 2014), 37.
} 
Ghanaians to the presence of these West Indians that emigrated to their nation are analyzed.

The socio-historical approach to history requires the historian to situate his or her findings in the larger global or social context, which in this study involves the use of a number of theoretical positions to interpret social phenomena in Ghana including: PanAfricanism, Socialism, African Nationalism, Diaspora, and Ethnicity. ${ }^{40}$ This approach necessitates both an inductive and deductive approach that shifts analysis from general applications of established theories, to testing the validity, implementation, and implications of these theories in the contexts of Ghana, Kwame Nkrumah, and these West Indian intellectual-activists . Within the social history framework, it is necessary to acquire sufficient and contextualized background information on the people or society being studied. This dissertation does so by applying primarily archival methods for collecting data.

\section{Sources of Data:}

This dissertation examines four different West Indian intellectual-activists George Padmore, W. Arthur Lewis, T. Ras Makonnen, and Jan Carew - who were instrumental in the formation, maintenance, and legacy of Kwame Nkrumah's Ghana. Each of these intellectuals was selected for the unique perspective and worldview that they brought to Ghana. The diversity in their ideologies and contributions are essential to this dissertation, as it stresses not only the unifying components of this group but also the points at which they diverge. While they all came from the West Indies, studied abroad,

\footnotetext{
${ }^{40}$ Isaac Olawale Albert. "Data collection and Interpretation in the Social History of Africa." Writing African History (2005), 302.
} 
and had their racial consciousnesses developed in the racialized social structures of the United States and Britain, their roles, approaches, contributions to Ghana's government and Pan-African institutions were marked by their varying abilities. For example, there was Padmore the ideological theoretician of Ghana's political and economic philosophies; Lewis the scholar of development economics and Economic Advisor to Nkrumah; Makonnen the multitalented businessman and institution builder; and Carew the artist, editor, and Advisor to Nkrumah's Publicity Secretariat. These varying perspectives and skillsets are used as entry points to analyze the influences, contributions, and local interactions of these West Indian intellectual-activists in Ghana.

I draw data from primary and secondary documents. The primary sources consist of first-hand accounts voiced in memoirs, oral histories, letters, treatises, newspapers, magazines, speeches, government documents, novels, and poems. The secondary documents for this project are derived from the historiography of studies of PanAfricanism, Black Internationalism, West African history, British Caribbean history, and post-colonial literature.

\section{Limitations:}

The primary limitation that presents itself in this dissertation is the absence of the contributions of West Indian intellectual-activist women, which necessitates the inclusion of a gender analysis of Ghanaian society. While this reflects the nature of politics and gender relations of the era, Black women from the West Indies, albeit not as intimately as their male counterparts, were indeed influential on Nkrumah and contributors to the nationbuilding process in Ghana. Another limitation that manifests is a preoccupation with the Accra Evening News, because of its significance to Kwame Nkrumah and the Convention 
People's Party. Since the Evening News served as the mouthpiece of the Nkrumah government, this dissertation draws more on its contents than any other state media press. Finally, in this dissertation's focuses on the West Indian experience in Ghana following independence, another limitation arises in the lack of an in depth examination of the colonialism in both the West Indies and Ghana, both of which would contribute to the socialization and politicization of the West Indian intellectual-activists, Nkrumah, and the oppositional forces in Ghana.

\section{Chapter Outlines:}

Since this dissertation is contributing to the discourse of Black Internationalism, it is fitting that the study's initial chapter begins in the African diaspora, specifically London, England. This chapter explores the origins of the Pan-African movement as well as the influence of West Indians on the concept, from coining the term to founding the movement at the turn of the twentieth century. In addition to underscoring the significance of the city of London to Pan-Africanism, the chapter also assesses the multifaceted contributions of George Padmore, W. Arthur Lewis, and T. Ras Makonnen to revitalizing the Pan-African movement following the Italian invasion of Ethiopia. The chapter also introduces Kwame Nkrumah and examines his initial encounters with the Pan-African movement at the Manchester 1945 Pan-African Congress, where African independence became the primary objective of the movement.

George Padmore is the focus of the second chapter. It explores the formation of his relationship with Nkrumah in London. After assessing Padmore's reconciling of socialism and Pan-Africanism, the chapter also examines the political education Nkrumah received under the tutelage of Padmore before he returned to Gold Coast. The 
chapter also examines how Padmore advised Nkrumah as he secured independence and continued to do so as Ghana's Advisor to the Prime Minister on African Affairs. In addition to helping formulate Ghana's Pan-African Policy, the chapter explores Padmore's reception by the Ghanaian nationalists working in Nkrumah's government, where his status as a "non-African" is examined, alongside the competing notions of diaspora, tribalism, and racial essentialism.

The third chapter provides a unique exploration of this era of Ghanaian history as it examines the contributions of Noble Prize-winning economist, Sir W. Arthur Lewis. First, Lewis' origins in St. Lucia and his journey to becoming one of the premier scholars of Development Economics in the 1950s are examined. Next, Lewis' contributions to the Pan-African movement through his work in the League of Coloured Peoples are detailed, as both his activist work and his reputation in British academic circles made him a highly sought after by Nkrumah. Lewis' time as Nkrumah's Chief Economic Advisor with also be closely examined to demonstrate his extensive contributions to spurring economic development and industrialization in Ghana. The chapter also highlights the deterioration of Lewis' relationship with Nkrumah as the economist's pragmatism began to clash with the vanity and economic gambles that Ghana's Prime Minister chose to take to place Ghana among the developed nations of the world. Furthermore, this chapter along with Padmore's are considerably longer than the others, as they examine their contributions and influences on both pre and post-independence Ghana.

The fourth chapter explores the contributions of the British Guianese Pan-African purist, T. Ras Makonnen. It first assesses Makonnen's work in Britain, where he demonstrated a distinguished business acumen and expertise in management. These 
skills, placed on display in the Pan-African movement, were later used by Nkrumah in Ghana. In addition to highlighting the multitude of ways Makonnen contributed to institution building and Nkrumah's Pan-African Policy through the African Affairs Centre, the chapter initiates an examination of Nkrumah's consolidation of power with himself as well as his efforts to implement socialism in Ghana, which Makonnen suggests never fully took hold.

The final chapter focuses on the contributions and observations of the Ghanaian society by Jan Carew in the final days of Nkrumah's regime. After examining his PanAfrican activism and authorship in London, the chapter assesses Carew's time as editor of the African Review magazine, as well as his service as Advisor to the Publicity Secretariat of the now recluse Nkrumah. Carew's initial observations of Ghanaian society serve as the foundation of the analysis of the discontent among the Ghanaian masses from the nation's worsening economic situation, corruption, disillusion with Ghana's PanAfrican Policies, and Nkrumah's despotic turn via authoritarian legislation. Finally, the chapter explores the fall of Nkrumah, the direct causes of the military coup, as well as the Pan-African efforts that facilitated Carew's escape from military custody.

This dissertation demonstrates how Padmore, Lewis, Makonnen, and Carew constituted the best of a generation of British West Indian intellectual-activists who greatly influenced the trajectory of Kwame Nkrumah and Ghana. These intellectuals serve as an entry point into interrogating the common understandings of the various socio-historical conditions, political ideologies at work in Ghana, as well as their impact on the Ghanaian masses and their implications for Ghana's first republic. Emphasizing the role of West Indian intellectual-activists in the advancement of Pan-Africanism as an 
ideology and movement in the interwar years, this dissertation it contends that West Indians were essential to governance and the shaping of post-colonial Ghana, particularly influencing the ideological and political trajectory of Kwame Nkrumah and the Ghanaian Government; the design of Ghana's economic development plans; the building of state institutions in furtherance of Nkrumah's Pan-African Policy; and Pan-African media outlets. Furthermore, I argue that the influence and contributions of Padmore, Lewis, Makonnen, and Carew to post-colonial Ghana exemplified the next phase of the PanAfrican movement as the ideology was placed into practice in governance and the building process of a free African nation-state. 


\section{LONDON, PAN-AFRICANISM, AND THE SEEDS OF INDEPENDENCE}

Since its inception, London, the British imperial metropole, was not only the center of colonial operations and the seat of power in the world but also the major site of imperial protest for the colored and colonized regions of the world. As British colonial subjects, many of these students began to migrate to London to continue their education. In Britain their shared conditions as subjugated people politicized and radicalized many of them. Ironically, as these colonial educated students, came to London to study colonialism and gain the necessary skills to improve the living conditions in their homelands, they also discovered the means to dismantle the colonial system all together. As they explored the merits of Marxism and sought to reconcile their class analyses of the colonial system with their racialized oppression, Pan-Africanism emerged as an organizing principle and ideology to promote international cooperation, solidarity, unity among African people. This chapter examines the intertwined histories of PanAfricanism and the city of London, and argues that the shared oppression of people of African descent and the abandonment of Ethiopia in 1935, necessitated Pan-Africanism's use to mobilize, organize, and insert the voices of Black discontent into the political discourse surrounding British colonialism. Also, through an examination of Black protest in London during the early decades of the twentieth century, the chapter argues that West Indians have always been at the fore leading, shaping, and directing the trajectory of the Pan-African movement. 


\section{Black Protest in the Imperial Metropole:}

As a dominant world power in Europe during slavery and colonization, Britain and London in particular - maintained a special place as a prominent site for the expression of African protest and discontent. In the eighteenth-century London witnessed the early abolition efforts of the formerly enslaved Olaudah Equiano, and Ottobah Cugoano's Sons of Africa organization, which campaigned in 1780's London for an end to Britain's participation in the trans-Atlantic trading of enslaved Africans. Shortly thereafter, Britain exercised its power in dictating the flow of global commerce by outlawing Trans-Atlantic slavery and began policing the Atlantic and the Indian oceans. During this time, in London, a runaway slave from the British colony of Jamaica, named Robert Wedderburn published The Horrors of Slavery. In his early nineteenth-century text, Wedderburn exposed under-discussed brutal aspects of the institution of slavery such as the rape of his mother, from which he was born, and the inhumane punishment practiced in the West Indies. The wealth derived from the cruelties of slavery allowed the British to dominate trade in West Africa, India, and the West Indies, leading to Britain's Industrial Revolution. Industrialization equipped the British with technology and weaponry that significantly shifted its interactions and relationship with the African continent, leading to its eventual colonization following the Berlin Conference of $1884 .^{41}$

By the turn of the twentieth century, the numbers of people of African descent in the British metropole steadily rose as West Indian and African students and seamen began to pass through London on a regular basis. ${ }^{42}$ Having recently passed the bar

\footnotetext{
${ }^{41}$ Joseph E. Inikori. Africans and The Industrial Revolution In England: A Study In International Trade and Economic Development. (Cambridge: Cambridge University Press, 2002)

${ }^{42}$ For more on this see: Ron Ramdin. The Making of The Black Working Class in Britain. (London: Verso Books, 2017)
} 
examination, a Trinidadian barrister named Henry Sylvester Williams sought to continue the legacy of Black protest in London. Inspired by T. Thomas Fortune's suggestion that "an association of the Africans and the descendants of Africa, from all parts of the world" was necessary, Williams founded the African-Association in October 1897 with the aim of encouraging unity amongst the African race and highlighting and informing public opinion of the various injustices in Britain's West Indian and African colonies. ${ }^{43}$ Concerned with the welfare of all people of African descent, Williams filled the association's offices and committees with law students and lawyers from the West Indies and Africa, and eventually gained the membership of prominent African Americans such as Booker T. Washington. Shortly, thereafter a Pan-African Conference took place in July $1900 .{ }^{44}$ At the conference discussions focused on slavery, colonialism, racism, and reparations, which ultimately produced an "Address to the Nations of the World," which condemned all forms of racial oppression against people of African descent across the globe.

The measures taken by Williams at the turn of the century served as defining moments for the global struggle against racism and the European colonialism for two reasons. First, Williams' calling of the Pan-African Conference of 1900 is unquestionably the formal beginning of the Pan-African movement and set the stage for London's continued significance as a space of African diaspora activism. Second, the formation of the African Association to the deteriorating economic conditions in the West Indies and the violence and racism of European colonialism in Africa, were indicative of how the

\footnotetext{
${ }^{43}$ Hakim Adi. Pan-Africanism and Communism: The Communist International, Africa and the Diaspora, 1919-1939. (Trenton, NJ: Africa World Press, 2013), 20.

${ }^{44}$ Marika Sherwood. Origins of Pan-Africanism: Henry Sylvester Williams, Africa, and the African Diaspora. (London: Routledge, 2012)
} 
Pan-African Movement would develop in the early twentieth century. Williams' vast network of West Indians in London and Paris aided in expanding the scope of the budding Pan-African movement. This is perhaps best demonstrated in his relationships with Haitian politicians Benito Sylvian and Antenor Firmin, who facilitated Williams' correspondence with Booker T. Washington, who supported, assisted in organizing, and promoted the Pan-African Conference in the United States.

In attendance at the 1900 conference was a young African American scholar named W.E.B. Du Bois, who would go on to organize four Pan-African Congresses that took place over the next two decades. While these congresses were accommodationist in nature and ultimately ceremonial meetings of the educated elites of people of African descent, Du Bois is recognized for revitalizing Pan-Africanism in the wake of the First World War. This has caused many scholars to overlook the efforts of H. Sylvester Williams and regard Du Bois as the "Father of Pan-Africanism." As a result, the role of African Americans as the driving force of Pan-Africanism is perhaps overstated in scholarship and among historians of Black Internationalism discourse. What is clear is that H. Sylvester Williams established Pan-Africanism as a recognizable term for the consolidation of transnational networks for collective organizing for liberation endeavors in the African Diaspora. Subsequently, Williams's efforts and example would be continued and amplified three decades later by a generation of West Indian intellectualactivists in London, whose critical analysis, agitating, and advising would spark the final assault of European colonialism and be vital wielding Pan-Africanism as an ideology for nation-building. 
Following the decline of H. Sylvester Williams' Pan-African Association shortly after the 1900 conference, organizations like the African Progress Union and the National Congress of British West Africa continued to advocate for the rights of Blacks in London and the colonies. ${ }^{45}$ In the early twentieth century, there were very few blacks, especially Black women, in London unless they were professionals, students, or dockworkers from Africa and the West Indies. As the First World War brought more Black students, laborers and military men to London, it necessitated political organization. ${ }^{46}$ Accordingly, London, where trans-Atlantic and imperial networks of people, ideas, culture, and perspectives converged, quickly became a locus of Black resistance to racism, colonialism, and empire. The result came in the concentration of Black intellectuals and activists in London establishing several new organizations and publications with the aim of serving the needs of people of African descent and to pressure the British government to enact reforms in the colonies.

Along with the W.E.B. Du Bois-organized the Pan-African Congress movement, the 1920s featured an unprecedented surge of Pan-African solidarity and organizing. This era also witnessed the meteoric rise of Marcus Garvey’s Universal Negro Improvement Association (UNIA) which amassed the largest Black movement the world had ever seen. ${ }^{47}$ By the 1930s, Blacks in Harlem were identifying with their counterparts in London, Freetown, Havana, and Paris. This notion of Black experiences, cultures, and identities transcending the national boundaries laid by European imperialism reflected a

\footnotetext{
${ }^{45} \mathrm{~J}$. Ayodele Langley. Pan-Africanism and Nationalism in West Africa, 1900-1945: A Study in Ideology and Social Classes. (Oxford: Clarendon Press, 1973), 124.

${ }^{46}$ Hakim Adi. "Pan-Africanism and West African Nationalism in Britain." African Studies Review 43, no. 1 (2000), 71.

${ }^{47}$ Ronald Jemal Stephens and Adam Ewing, eds. Global Garveyism. (Gainesville: University Press of Florida, 2019)
} 
Pan-African consciousness among the Black masses. As a result, when Benito Mussolini mounted an invasion of Ethiopia in 1935, Blacks in Africa, the United States, West Indies, and London, despite their own meager circumstances during the Great Depression, rallied to the aid of Ethiopia and wrote "the most glorious chapter the history of pan-Africanism and international Black solidarity." ${ }^{48}$

By the early 1930s the West African Student Union (WASU), League of Coloured People (LCP), and the Negro Welfare Association (NWA) dominated the Black political landscape in London. In 1925 Ladipo Solanke, a Nigerian law student, founded WASU and established its own Wasu journal and the Aggrey African student hostel, which housed the majority of African and West Indian students living in London at some point in their studies. WASU served as a voice for anti-colonial opinions and protest in London and had branches in Africa, Brazil, the West Indies, and the United States. Although it was comprised primarily of African students, WASU was heavily influenced by the Pan-Africanism emanating from the West Indies at the time, particularly that of Marcus Garvey, who mentored the group early on, financed the launch of its journal, and even transferred the lease on his London home to WASU when he left London in 1928. Eventually, WASU became arguably the most important pressure group on African and colonial issues in London. Such was the reach and influence of WASU in the late 1920s that Amy Ashwood Garvey, regarded WASU and Solanke as the "successors of Mr. Marcus Garvey." ${ }^{49}$

\footnotetext{
${ }^{48}$ Winston James. Holding Aloft the Banner Of Ethiopia: Caribbean Radicalism In Early TwentiethCentury America. (London: Verso Books, 1998), 259.

${ }^{49}$ Matera. Black London. (2015), 29.
} 
Similarly, West Indian leadership manifested again in founding of the LCP $n$ 1931 by Harold Moody, a Jamaican physician, and served as a militant organization of Negro workers that highlighted colonial matters, and protested racism and the color bar in the British metropole. While the LCP's membership was not racial exclusive, including white British and South Asian members, Moody maintained that it first and foremost championed Black unity and concerned itself with advocating for people of African descent around the world, particularly on issues of discrimination in housing and employment, and the plight of the children of interracial working-class families in Britain. ${ }^{50}$ Comprised of African and West Indian seamen based in London, The NWA was founded in 1931 initially because of the British communist party's failure to follow the Communist International (Comintern) and the International Trade Union Committee of Negro Workers' (ITUCNW) initiatives to address the issue of anti-colonialism in Africa and West Indies. ${ }^{51}$

Although its officers and constituents were overwhelmingly Black communists from the West Indies, The NWA often collaborated with anti-colonial organizations in West and East Africa. This trans-oceanic collaboration was the culmination of $\mathrm{H}$. Sylvester Williams' work, as Pan-African networks in London and the empire were solidified and transcended political ideologies. The converging political interests and shared conditions of oppression of these West Indians and Africans ultimately led to the membership of these organizations often overlapping in the early 1930s. They exchanged their respective publications, as well as participated in each other's conferences, protests, forums, and social events. While these organizations often had

${ }^{50}$ Ibid., 41.

51 Adi. Pan-Africanism: A History. (2018), 110. 
varying perspectives and ideologies (i.e. Communism, African Nationalism, or Colonial Reformism) they shared similar political goals and there was a persistent presence of West Indians among their leadership. As these trans-oceanic collaborations and networks persisted through the early decades of the twentieth century, the rise of fascism in Europe and an imminent Second World War were met by a Pan-African united front that had yet to be seen in the Black liberation movement as the storied African nation of Ethiopia encountered its greatest hour of need.

The Ethiopia Crisis Shifts Pan-Africanism to the Left

Ethiopia has maintained a special appeal to people of African descent and Europe. Emperor Menelik II's victory over of Italy's initial invasion in 1896 with the Battle of Adwa enriched the global interest as it established the nation a formidable independent state and in that instance, dispelled the notion, at least for Ethiopia, of Africans being barbarians and insignificant in matters of the modern world. Following the Battle of Adwa, European nations rushed to sign trading treaties, offered aid to modernize the nation, and Ethiopia went on to join the League of Nation shortly after its founding. For people of African descent, Menelik's victory over Italy fortified the collective fascination of this storied African nation and its monarchy that had never been conquered in history. Psalms 68:31: "Princes shall come out of Egypt; Ethiopia shall soon stretch out her hands unto God" was one of the most widely quoted Bible verses of in the African diaspora, and the triumph of this biblical Africa nation, assured the validity of this biblical prophecy. In the 1930s interest in Ethiopia was revived when Haile Selassie I was crowned Emperor and "King of Kings of Ethiopia." The lavish coronation received international acclaim and was attended by royals and dignitaries from across the globe. 
For people of African descent, the coronation of an African monarch that traced his lineage back to Solomon spurred the Rastafari movement in Jamaica and reinforced the legitimacy of the nation's past veneration in the Ethiopianism movement and the rituals and cultural performances of the UNIA. Indeed, Ethiopia symbolized the pinnacle of African independence and resistance to European imperialism. ${ }^{52}$

In the early twentieth century, Ethiopia was a source of hope and inspiration for several radical Black Nationalist, Pan-African, and African Nationalist movements seeking an end to colonialism, and racial oppression experienced by people of African descent. The invasion of Africa's last independent nation by Mussolini's fascist Italian regime Africans incited an emotional reaction of distress among people of African descent around the world. Mussolini's invasion and eventual occupation of Ethiopia in 1935 represented the completion of Europe's conquest of Africa. Italy's fascist invasion and occupation of Ethiopia brought the last stronghold of independence in Africa alone to face: the use of mustard gas, the bombing of Red Cross hospitals and ambulances, the execution of captured prisoners without trial, the Graziani massacre, the killings at Däbrä Libanos monastery, and the shooting of "witch-doctors" accused of prophesying the end of fascist rule. ${ }^{53}$

The inaction of the League communicated to people of African descendent that they alone would have to stand with and if possible fight alongside their Ethiopian brothers and sisters in the war against Italy. In the United States, African Americans were eager to travel to Ethiopia to join their Africa brothers in the war against Mussolini

\footnotetext{
${ }^{52}$ Meriwether. Proudly We Can Be Africans. (2002), 30.

${ }^{53}$ Richard Pankhurst. "Italian Fascist War Crimes in Ethiopia: A History of Their Discussion, from the League of Nations to the United Nations (1936-1949)." Northeast African Studies 6, no. 1/2 (1999), 83.
} 
and fascism. In the West Indies, riots broke out in the British colony of St. Kitts. Africans on the continent and in the diaspora witnessed Ethiopia, a member of the League of Nations, subjected to failed toothless sanctions imposed on Italy by the League; the Hoare-Laval compromise that would claim Ethiopia as an Italian colony; and Britain's recognition of Italy's conquest in May of $1936 . .^{54}$

As the European powers united in their inaction against Italy, this display of PanEuropeanism was interpreted by Black peoples as a concerted attack against Blacks everywhere. In London, where the color bar had relegated blacks to second class citizens, Africans and West Indians looked on as Europe and the rest of the world allowed the sovereign nation of Ethiopia to be conquered. With the credibility of the League of Nations in question and a new world war approaching, growing unrest occurred throughout the colonies. Mussolini's invasion pushed Africa to the forefront of all political debate in Britain. Passing through London in 1935 on his way to study in the United States, a young Kwame Nkrumah, future Prime Minister of Ghana and largest proponent of Pan-Africanism in the post-war years, saw a newspaper announcing, "MUSSOLINI INVADES ETHIOPIA," and remembers that it felt "as if the whole of London had declared war on me personally." ${ }^{55}$ Little did he know that during his time in the United States his future friends, mentors, and advisors were mobilizing black political organizations in London for a Pan-African united front to support Ethiopia and eventually against the colonialism structure as a whole.

Revitalization and Rebirth:

${ }^{54}$ Harris. African-American Reactions To War In Ethiopia. (1994), 34-35.

${ }^{55}$ Matera. Black London. (2015), 62. 
The crisis in Ethiopia along with the ensuing Second World War proved to sever the relationship between many Black Marxists and the Comintern, as the Soviet Union's foreign policy began to reflect the insincerity of appeals to the Black workers of the world. For many Black Marxists, the Italian invasion of Ethiopia in 1935 was the turning point that ended their involvement with the Communist movement. Five years later, the ultimate betrayal of Communism came in the Hitler-Stalin pact of 1939, which led several Black Marxist intellectuals to experience great intellectual turmoil causing them to re-examine the fundamental Marxist texts and the formulations of theories. ${ }^{56}$

Cedric Robinson suggests that Black Marxist intellectuals viewed fascism as a blood relative of slavery and imperialism, which were all global systems rooted in capitalist economies and racist ideologies.${ }^{57}$ Soviet Russia's failing to aid Ethiopia pushed many Black communists beyond the ideas of Marx and Lenin toward a deeper analysis of the colonial power structure and methods for global black resistance. In the end, the contradictions exhibited by Russia's foreign policy could not be forgiven by many Black radicals. Many Black Marxists refused to trade their British or French colonial masters for Russian ones. Instead they turned their focus completely to the issues of African peoples and an embracing of Pan-Africanism. This shift away from communism led to a large influence of communist principles on Pan-Africanism that marked a new era of the Pan-African movement.

Among these Black Marxists was the prominent Trinidadian journalist and “ideological commissar of Black radicalism," George Padmore. Padmore formally ended his service with the Communist International in 1934, and he found himself in London

\footnotetext{
${ }^{56}$ Padmore. Pan-Africanism or Communism, 154.

${ }^{57}$ Robin DG Kelley. Freedom Dreams: The Black Radical Imagination. (Beacon Press, 2002.), pp. 56.
} 
where he quickly involved in local politics. Speaking at a political meeting in Gray's Inn Road, Padmore made an unlikely encounter with an old friend, C.L.R. James. Now regarded as the magisterial, world-historical intellectual of the twentieth century anglophone Caribbean, ${ }^{58}$ James attended the event at Gray's Inn Road only to find that Padmore was his friend from Trinidad, Malcolm Nurse. By this time, James had been living in London for three years and had become a prominent speaker on the global Black condition and an outspoken leader of the emerging Trotskyist movement among communists in Britain.

In 1935, as head of the Finchley/Hampstead branch of the International Labour Party, James traveled the British Isles appealing to the workers of Europe to rally behind the Black population of Ethiopia. He found that British socialists were spilt on the issue of Ethiopia. Part of the ILP leadership opposed direct action in support of Ethiopia because the cause was not socialist but rather a nationalist issue. On the other hand, some believed that promoting working-class sanctions would cultivate a psychology of war against fascist Italy. Neither of these approaches centralized Ethiopia nor the issue of race to directly support of the plight of Ethiopia. James had already been at odds with the British left, as many British socialists had begun advocating for an internationalization of the colonial administration or an inter-imperialism to ease competition for resources and territory between the major powers of Europe. These proposals, like the Berlin Conference of 1884 , were tantamount to an internationally coordinated form of imperialism and ratification of the color line on a global level.

${ }^{58}$ Bill Schwarz. West Indian Intellectuals in Britain. (Manchester University Press, 2003.), 133. 
This "collective imperialism," according to Matera, demonstrated a widening gap between British communists and socialists, who "attributed war and economic exploitation to capitalism, of which imperialism was but an epiphenomenon," and the Black intellectuals in the British metropoles who centralized imperialism as "the driving force behind an increasingly monopolistic form of capitalism and the most resolute barrier to cross-cultural cooperation and socialism." ${ }^{\text {59 }}$ It was apparent that the major European nations, as well as European communists and socialists, were willing to sacrifice Ethiopia and possessed very little interest in confronting colonialism. As European communists and socialists abandoned anti-imperialism for anti-fascism, Black intellectual-activists argued that anti-imperialism was inextricably linked to anti-fascism. For James, a universal intellectual whose social analysis was driven by the constraints imposed by both racial and capitalist structures, the Ethiopia Crisis and the turmoil within communist circles left him to conclude that "Africans must win their own freedom, [and] Nobody will win it for them." 60

As a result, in July 1935 James enlisted Padmore to help revitalize the PanAfrican movement with the formation of the International African Friends of Abyssinia (IAFA) "to assist by all means in their power in the maintenance of territorial integrity and political independence of Abyssinia." ${ }^{61}$ With two West Indians forming the IAFA leadership, their use of the term "African" in the organization's name reflected the organizations (and their own) commitment to Pan-Africanism and the centralizing of Africa in their identity. While Africans such as Jomo Kenyatta (Kenya) and Mohammed

\footnotetext{
${ }^{59}$ Matera. Black London. (2015), 77.

${ }^{60}$ Schwarz. West Indian Intellectuals in Britain. (2003), 133, and C.L.R. James. A History of Pan-African Revolt. (Oakland, Calif: PM Press, 2012), 14.

${ }^{61}$ Quoted in Hakim Adi. Pan-Africanism: A History. (London: Bloomsbury Publishing, 2018), 108.
} 
Said (Somalia) were among the IAFA's initial members, the rest of leadership was overwhelmingly West Indian, with James as chairman, T. Albert Marryshaw from Grenada as vice-chairmen, Amy Ashwood Garvey as treasurer, and finally Padmore and the Guyanese entrepreneur Ras Makonnen completing the executive committee. An old friend of Padmore's from his time as a student at Howard University, Makonnen had recently arrived in London after being deported from Denmark for his own outspoken views. Unimpressed with the existing African and West Indian political organizations in London, describing them as "very mild," Makonnen and the IAFA formed a new cohort of Black intellectual-activists that quickly called for a Black united front among organizations in Britain.

Once again, London had become an epicenter for anti-colonial and anti-fascism for British colonial subjects as it had for H. Sylvester Williams and the African Association in 1897. Britain was, according to Makonnen, "really in ferment - seething, in fact, like an African pot." 62 In London, the British commitment to individual liberties allowed African and West Indian intellectual-activists to enjoy a freedom of expression unavailable in the colonials. As a result, they were able to form radical organizations in Britain, which were regularly ignored by authorities. Such freedoms of speech, organizing, and agitation were unthinkable in the colonies, where authorities regularly violently repressed radicalism and resistance in any form. As more African and West Indian students, intellectuals, activists, and artists from Africa and the West Indies passed through or settled in London, the emergence of London's Black neighborhood of Soho with its jazz clubs, restaurants, and lounges became an important site for Pan-African

\footnotetext{
${ }^{62}$ Matera. Black London. (2015), 63.
} 
activity. African American musicians jammed with Black London house bands, songs supporting anti-imperialist movements were performed, and transatlantic networks were formed. It was mostly here that African and West Indian students, intellectuals, and activists debated the issues of the day and forged political alliances.

This new Pan-African locale proved vital to the IAFA, as it established its headquarters at Amy Ashwood Garvey's International Afro Restaurant on New Oxford Street. Not only did Ashwood Garvey's establishment serve as a formal space for organizing and planning for the IAFA, it also reflected the linkages to and ideological continuation of the Pan-Africanism heralded by the Marcus Garvey's Universal Negro Improvement Association. From its inception, the IAFA pledged to support the Ethiopian to maintain its independence, denounced Mussolini's fascism and demanded that the League of Nations intervene. Marking a sharp departure from the reformism of Dubois' 1920's Pan-Africanism, the radicalism of the IAFA and its members called "upon all Africans and people of African descent all over the world to...pledge themselves to assist Abyssinia in her struggle by all means at their disposal." ${ }^{\text {"63 }}$ According to James, we "wanted to form a military organization which would go to fight with the Abyssinians against the Italians." 64 While Ethiopian representatives in London dissuaded them from military action, the IAFA spearheaded a "Hands Off Abyssinia" movement in London, that propelled a spike in radicalism and Black political organizing. The crisis in Ethiopia pushed Black consciousness in London towards Africa, and united Africans and West Indians "against what they saw as the common front of imperialism."

\footnotetext{
${ }^{63}$ Marika Sherwood, “An Emperor in Exile Part 2,” 20-21; Labour Monthly, 17/9 (September 1935), 532536.

${ }^{64}$ Adi. Pan-Africanism: A History. (2018), 110.

${ }^{65}$ Matera. Black London. (2015), 68.
} 
By the fall of 1935, Ethiopia became a rallying point in London as the renamed International African Friends of Ethiopia (IAFE) regularly partnered with the WASU, the LCP, and the NWA. Just as membership of these preexisting Black organizations regularly overlapped, Padmore, Makonnen, and Kenyatta were known to frequent LCP meetings and the WASU's Aggrey House to recruit African and West Indian students for membership. Such cooperation came to a head when the IAFE, WASU, LCP, The Somali Association, and NWA that welcomed the exiled Ethiopian Emperor Haile Selassie I to London in 1936. While Selassie was cool on the idea of Pan-Africanism, by contending that Ethiopians were a "mixed Hamito-Semitic people" and not "Negros," this moment of Pan-African unity in London should be regarded as the forming of that Black united front that Makonnen had been calling for. ${ }^{66}$ Beyond this instance, these organizations collaborated regularly, speaking at each other's rallies and publishing articles in each other's journals. After African American scholar Ralph Bunche declined to speak at an LCP fundraiser for Ethiopian refugees, Padmore assumed the responsibility in his place and presided over the event. Writing in the LCP's journal, The Keys, James attributed the rise in radicalism among British colonial subjects to the betrayal of Ethiopia stating: "Africans and people of African descent, especially those who have been poisoned by British Imperialist education needed a lesson," and in the Ethiopia Crisis "They got it." Ultimately, the Ethiopia crisis led to further radicalization among these organizations and its members. For many of these organizations Mussolini's invasion was tantamount to a racial war and led to them openly criticizing the hollowness of

\footnotetext{
${ }^{66}$ Samuel KB Asante. Pan-African Protest: West Africa and the Italo-Ethiopian Crisis, 1934-1941. (London: Longman Publishing Group, 1977), 60.

${ }^{67}$ Matera. Black London. (2015), 70.
} 
Britain's diplomatic maneuvering. The Italian invasion and Britain's lack of response to it, exposed the illegitimacy of British colonial rule as well as the moral and spiritual bankruptcy of West Civilization. Sharing these sentiments was the seemingly conservative, St. Lucian economist W. Arthur Lewis, who had risen through the ranks of experts on colonial economics in Britain. Lewis, a Fabian socialist and long-time member of the moderate LCP, also joined the IAFA and noted that Britain's perceived appeasement and collusion with Italy's invasion had destroyed "faith in white government, and to make them more willing to take their fate in their own hands." ${ }^{68}$ As a result of the lessons from the Italian invasion of Ethiopia and the toothless response by the League of Nations, the Pan-African politics of African and West Indians in London now became fixated not on reforming the colonial system but rather solely on bringing about its destruction.

\section{Pan-Africanism as an Anti-Colonial Movement:}

The Ethiopia Crisis united several organizations in Britain; however, like this moment in history, the IAFE did not last for long. Like the Pan-Association decades earlier, the IAFE dissolved due to internal disagreements that ultimately resulted in C.L.R.' James' resignation from its ranks. Police reports from late 1935 suggest that simultaneous to James's departure, Padmore began forming a new organization called either the Pan-African Brotherhood or the Pan-Afro League. ${ }^{69}$ This organization eventually came to be known as the Pan-African Federation for the Defence of Africans and People of African Descent. Although members of the IAFE provided a seamless

\footnotetext{
${ }^{68}$ W. Arthur Lewis. Lewis Labour in the West Indies: The Birth of a Worker's Movement, (London: New Beacon Books, 1977), 19., in Adi. Pan-Africanism: A History. (2018), 117.

${ }^{69}$ Adi. Pan-Africanism: A History. (2018), 117.
} 
transition by quickly joining Padmore's organization, the Pan-African Federation (PAF) struggled financially and achieved very little at this moment in time. At a PAF meeting in April 1937, they discussed the necessity of an African Bureau and Journal for exchanging information regarding African problems and African liberation.

Padmore, James, Jomo Kenyatta, and Sierra Leonean trade unionist, I.T.A. Wallace-Johnson, who had collaborated and frequently corresponded with Padmore during his time in the Comintern, were elected to a planning committee. The result was the formation of a new groups called the International African Service Bureau (ISAB), which quickly stocked its leadership with Padmore as its chairman, Wallace-Johnson as general-secretary, Makonnen as fundraiser and treasurer, and Kenyatta and Amy Ashwood Garvey in leadership roles. C.L.R. James also came on board as editorial director of the IASB's publications the African and the World, the African Sentinel, and the International African Opinion. ${ }^{70} \mathrm{~W}$. Arthur Lewis, although still a graduate student at the London School of Economics also advised the IASB on matters of colonial economics. James suggests that the IASB was assembled able to operate on such a large scale primarily because of "Padmore's encyclopedic knowledge of Africa, of African politics and African personalities, [and] his tireless correspondence with Africans in all parts of the continent."."1

While the IASB emphasized the duplicity and savagery of European imperialism and grew directly from the Ethiopian crisis, its interests and concerns applied to the broader African world. The collective outrage and protests in response to Ethiopia demonstrated the necessity of strengthening these trans-oceanic networks and optimizing

\footnotetext{
${ }^{70}$ Padmore. Pan-Africanism or Communism. (1971), 126.

${ }^{71}$ Matera. Black London. (2015), 82.
} 
the flow of information on current events in Africa and the diaspora. As such, the organization's purpose, according to James, was to assist "by all means in our power the uncoordinated struggle of Africans and the people of African descent against the oppression from which they suffer in every country."72 Reflecting on the recent turn towards Africa within Black activism, the predominantly West Indian organization fashioned itself as African to solidify their Pan-African identity.

This Pan-African identity transcended national borders and ethnic divisions in favor of a racial essentialism sustained by the ongoing oppression and disenfranchisement derived from the colonial system. The focus for the bureau, according to Makonnen who also wrote the organization's constitution, was to stress cooperation and "to emphasize service to people of African descent in as many ways as possible - education economic co-operative and political." ${ }^{.73}$ Imperative to this was the bureau's ability to link the struggles taking place in Britain's "tropical empire" - a term to encompass British colonization in Africa and the West Indies (as opposed to nonBlack colonies and dominions like Canada, Australia, India, Hong Kong?)- in order to create a viable analytical framework for a collective stream of Pan-African consciousness.

Living up to its motto of "EDUCATE - CO-OPERATE - EMANCIPATE: Neutral in nothing affecting the African Peoples," the IASB's became a Pan-African institution dedicated to collecting and disseminating information about the struggles of the African Diaspora across the globe. In an advertisement appearing in the leftist journal Fact, the IASB billed itself as "primarily an African organization, run by

\footnotetext{
${ }^{72}$ Matera. Black London. (2015), 83.

${ }^{73}$ Ras Makonnen. Pan-Africanism From Within. (Nairobi; New York: Oxford University Press, 1973.), 118
} 
Africans...[that] serves as a clearinghouse of information" on matters affecting people of African descent. It supplied speakers to organizations, convened meetings and discussions, published pamphlets, books, and memoranda "anti-imperialist in character and outlook." ${ }^{\prime 4}$ A decade earlier, Marcus Garvey's The Negro World newspaper served a similar purpose in keeping the African world informed on current events in the West Indies, Africa, and even the local intra-racial squabbles in Harlem. The IASB found itself building upon this legacy of service to African people as it filled the void left by the decline of Garvey and his UNIA. Whether deliberate or not, the West Indian street corner orator tradition of the 1910s and 1920s Harlem was invoked by Padmore, James, and Makonnen, who were all known to frequently address audiences at Hyde's Park and Trafalgar Square. In these public speeches the London public witnessed Padmore now an anti-Russian Pan-African socialist, James the Marxist theorist, and "the unconquerable" Makonnen known to begin his speeches by brazenly calling for "war" because was "the only way we are going to get our rights." 75

While the IASB was internationalist and socialist in scope, it distinguished itself from the rest of the European left by contending that among all people of African descent possessed "a common bond of oppression, and as the Ethiopian struggle has shown, all Negroes everywhere are beginning to see the necessity for international organization and the unification of their scattered efforts." 76 The bureau's demonstrations, lectures, publications, and forums were geared towards Black workers as they highlighted trade union strikes in the West Indies, cocoa planters boycotts in Nigeria and Gold Coast, and

\footnotetext{
${ }^{74}$ Kent Worcester. CLR James: A Political Biography. (Suny Press, 1995.), 32.

${ }^{75}$ Worcester. CLR James: A Political Biography. (1995), 33.

${ }^{76}$ Matera. Black London. (2015), 83.
} 
protested repressive legislation as well as the confiscation of progressive literature that had been rampant in the colonies for decades. Despite Makonnen's fervent opposition to communism, the IASB attracted several young Black intellectuals in Britain who held Marxist values. The leftist members of the IASB, who also held positions in nationalist and labor movements throughout African and the Diaspora, such as Coloured Workers Association; the All-Seamen's Union in Sierra Leone; The Kikuyu Central Association in Kenya, became familiar with ideals of Pan-Africanism through the bureau's study groups. Although the IASB's communist rhetoric at times strained its working relationships with other Black organizations in London, they were usually able to reconcile their differences and agree on the necessity of equality and self-determination for all colonial people.

Such was the case in the spring of 1938 when the IASB collaborated with the LCP and NWA to protest the British Parliament and the Colonial Office for their handling of recent strikes, mass protests, and police brutality in Trinidad, Jamaica, and Barbados. Due to the IASB's past demonstrations in support of the cocoa strikes in the Gold Coast and British Colonial Office feared that worker unrest in the West Indies could eventually spread to Africa. Seizing upon the situation, the IABS printed a pamphlet entitled The West Indies Today, in which they advised the dockworkers and oil and sugar plantation workers to build up powerful trade unions and urged the worker to realize that their economic struggles could not be divorced from their political aspirations. ${ }^{77}$

The bureau labeled the conditions surrounding and British response to the strikes in the West Indies as "Colonial Fascism," and considered the situation to be a clear

${ }^{77}$ Esedebe. Pan-Africanism. (1994), 110 
"warning against future occurrences of a similar in nature in any other section of the Colonial Empire."78 Following a protest, the IASB's executive committee passed a resolution demanding the immediate release of incarcerated labor organizers in the West Indies, and colonial reforms in the form of land settlement schemes, improved housing, banning of child labor, and above all, a fully democratic constitution. These demands, along with similar resolutions from the LCP, led to Parliament to form a West Indian Royal Commission to investigate the economic and social causes of the disturbances in the West Indies. This was due to the disturbances and unrest in the tropical colonies seemingly making their way to London, where the IASB was not only radicalizing the Black population but also gaining sympathizers in white leftist organizations and colonial subjects from India and Asian nations, with their own colonial experiences.

As the Commission readied its investigation, the IASB, NWA, and the LCP presented it with a memorandum on the "economic, political, and social conditions in the West Indies." More specifically the groups demanded the rescinding of all sedition ordinances as well as the right to form trade unions, a ten million dollar housing scheme, free primary and secondary education and the establishment of a West Indian university, removal of racial discrimination in the colonial civil service, and various of social welfare measures. ${ }^{79} \mathrm{Co}$-authored by a joint committee of the three organization that included Padmore, James, Lewis, and Makonnen, the report connected the current disturbances in the West Indies to outrage prompted by the Italian invasion of Ethiopia suggesting that "when the rape of Ethiopia has given a great stimulus to growing Negro consciousness, it is not a question of rebellions if, but rebellions unless, democratic government is

\footnotetext{
${ }^{78}$ Matera. Black London. (2015), 93.

${ }^{79}$ Esedebe. Pan-Africanism. (1994), 110
} 
granted." ${ }^{80}$ Makonnen contended that if there was going to be a commission investigating the trade union conditions in the West Indies "we were determined to submit a manifesto...that did not restrict itself to one small fragment, but showed what was happening in West Africa as much in the West Indies." 81 This memorandum reflected the centrality of print culture within Pan-African activity in London, as well as how imperative it was for the intellectual and organizational groundwork taking place in Europe to be linked to the radical and grassroots movements taking shape in the colonies.

Padmore, Makonnen, and Lewis were outspoken in London print media, conferences, demonstrations, and their own texts highlighting the failures of colonial economic policy, the fascism of the colonial administrations, and the illegitimacy of British rule in Africa and the West Indies. In a September 1938 pamphlet printed by the IABS, entitled Europe's Difficulty Is Africa's Opportunity, the bureau called upon people of African descent across the world "to organize yourselves and be ready to seize the opportunity when it comes." 82 The time would soon come as a trans-Atlantic print culture in the form of books, pamphlets, and journal publications, especially the emanating from London served to link the imperial and trans-Atlantic networks, thus realizing the IASB's aim of serving as an information dissemination bureau. ${ }^{83}$

James left the IASB in late 1938 when he left London to join the social struggle in the United States. While the bureau had lost its chief theoretician, the IASB pressed on

\footnotetext{
${ }^{80}$ Matera. Black London. (2015), 94.

${ }^{81}$ Ibid., 97.

82 Ibid., 98.

${ }^{83}$ Leslie James. "Trans Atlantic Passages: Black Identity Construction in West African and West Indian Newspapers, 1935-1950." in African Print Cultures: Newspapers and Their Publics in the Twentieth Century, edited by Derek Peterson, Steph Newell, and Emma Hunter, 49-74. (Ann Arbor: University of Michigan Press, 2016); Carol Polsgrove. Ending British rule in Africa: Writers in a Common Cause. (Manchester: Manchester University Press, 2017)
} 
and eventually became the pivotal link between all the Black organizations in Britain. In the early 1940s Padmore and the bureau linked the current crusade against Hitlerism with colonial freedom. Advocating for self-determination, freedom, and equality as inalienable rights of all people "regardless of the stage of their social and cultural development," the bureau seemingly anticipated the Atlantic Charter. As IASB, LCP, and WASU members increasingly attended each other's meetings and demonstrations, published one another's journals, and planned international conferences for Black organizations, an overarching organization for the Black organization of the British empire to voice their collective demands and initiatives was deemed necessary.

As a result, in 1944 Padmore dissolved the IASB in order to rehabilitate the PanAfrican Federation and to organize the Manchester Pan-African Congress. Continuing the Pan-African movement started by H. Sylvester Williams, the Pan-African Federation's main objectives were: To promote the well-being and unity of African peoples and people of African descent throughout the world; To demand self-determination and independence of African peoples; The total abolition of all forms of racial discrimination; and To strive to co-operate between African peoples and others who share our aspirations. ${ }^{84}$ Furthermore, this pairing of Pan-African objectives with the trade union and colonial nationalist movement connections of its members proved central to the PanAfrican Federation's organizing of the Manchester Pan-African Conference of 1945. In addition to the hostilities and Black outrage spurred by Italy's fascist invasion of Africa, the British government's weakening grip on its colonies, and a war-torn London, the result of the ensuing second world war, Britain was left still to reckon with the fact, as

\footnotetext{
${ }^{84}$ Padmore. Pan-Africanism or Communism. (1971), 127.
} 
James later stated: "the black-intellectuals had not only arrived but were significant arrivals." ${ }^{85}$

\section{Black in the Home of Empire}

In addition to the radical intellectual-activists like Padmore, James, and Makonnen, the 1930s saw the arrival of African and West Indian students entering British universities, where they challenged and drove change in the fields of history, economics, the social organization of colonial societies. Upon their arrivals in London, many of these black students, who may have initially thought of themselves as "British intellectuals," quickly came to see themselves as members of a global black community. Over time, their endeavors took on a Pan-African character that tended to transcend their own initial personal aspirations. Among them were W. Arthur Lewis, Eric Williams, Jomo Kenyatta, Peter Mbiyu, Kwame Nkrumah, Nnamdi Azikwe, and Kofi Busia. Like the Pan-Africanists of the previous three decades, these students formed a new educated elite.

The influence of radical organic intellectuals and activists like Padmore, James, and Makonnen, however, was able to temper elitism and mentor this next generation of Pan-Africanists. Together, they engaged in debates that considered the real-world applications of the theories broached in academic spaces as well as Pan-Africanism itself. Often the products of British colonial educations, these Africans and Caribbean students in London often studying law, medicine, or anthropology transcended the barriers of the academy to critique and build upon the social analyses and philosophies surrounding

\footnotetext{
${ }^{85}$ Matera. Black London. (2015), 95.
} 
colonialism, socialism, and freedom to create material demands for independence from the British Empire.

As the political demands of African and West Indians were intensified in the 1930s, so too was the research of Black intellectual activists with perspectives that criticized and advanced the often narrow and mediocre scholarships directing colonial studies scholars of the time. Often the products of British colonial educations, these Africans and West Indian students in London often studying law, medicine, or anthropology would transcend the barriers of the academy to critique and build upon the social analyses and philosophies surrounding colonialism, socialism, and freedom to create material demands for independence from the British Empire. Accordingly, as the political demands of African and West Indians swelled in the 1930s, so too did the desire for intellectual-activists with perspectives that criticized and advanced the often narrow and mediocre scholarships directing colonial studies scholars of the time.

As a result, a colonial Black intelligentsia was cultivated via this network. Together, they pressured the British government and academy for substantive reform and contributed to the scholarship concerning colonial affairs and the conditions throughout the colonies. Forming the basis of a new class of nationalists/anti-colonial intellectualactivists, many of these students leaped at the opportunity to contribute to and eventually dominate "an expert community which might better guide colonial policy." ${ }^{86}$ Already engaging in rigorous public debates on the future of the colonies and of British colonialism, many of the free-flowing ideas exchanged in these Black activist spaces subsequently entered the British academy. By the nature of their colonial upbringings,

\footnotetext{
${ }^{86}$ Ibid., 242.
} 
encounters with the British color bar, and vibrant political scene in London, these African and West Indian scholars found themselves at the forefront of the drive to expand the field of colonial studies.

Eventually, changes came in the form of new lectureships, courses, curriculum, and professorships with the purpose of driving intellectual engagement of colonial reform. The expertise required in these academic settings equipped these Black intellectuals with the theoretical tools and perspectives that informed their political claims and demands. Ironically, this generation colonial educated students, many future leaders of independent Black nations, came to the capital of the British empire to study colonialism and discovered the means to dismantle it. For many of them, there was a constant struggle to present their research as scientific studies as opposed to anti-imperial propaganda. Although many like Eric Williams (The Williams Thesis), Jomo Kenyatta (Facing Mount Kenya), and W. Arthur Lewis (The Duel-Sector Model) persisted and thrived in academic settings, others of this generation like Kwame Nkrumah found their calling not in their scholarship but in their activism.

\section{Nkrumah Enters the Movement}

Arriving in Liverpool in the fall of 1945, Nkrumah was a student from the Gold Coast who had recently completed his studies at Lincoln University. Meeting him at the Euston Station was nonother than George Padmore. Although the two had never met in person, Padmore held a letter from his old friend, C.L.R. James, who wrote him a letter of introduction to a young African student named Francis Nkrumah. According to James, the student was not overly impressive, nor were there any expectations for him, but James 
asked Padmore to do what he could for him in London. ${ }^{87}$ Now going by Kwame, he arrived with the intention of becoming a barrister or enrolling at the London School of Economics for a Ph.D. in Anthropology with a dissertation topic focusing on "Knowledge and Logical Positivism;" however, this would not last long as Nkrumah quickly fell under the mentorship and tutelage of Padmore. It made sense that James sent Nkrumah to Padmore, as he was a seasoned organizer and agitator in Pan-African and socialist networks throughout London and the world. Upon meeting him, Padmore took Nkrumah not to eat or to the WASU hostel where he found him lodging, but to a railroad union meeting to introduce him to the members of the Pan-African Federation. Operating in activist settings was not new to Nkrumah.

Nkrumah's studies in religion and philosophy at Lincoln University were accompanied by his discussions of radical socialism, imperialism, and colonialism from CLR James. The two men met in 1941 and in two years developed a student/teacher relationship that would last for decades. It was through James, according to Nkrumah, that he "learned to how an underground movement worked." 88 Already one of the foremost Black Marxist theorists and scholars of the era, James took Nkrumah under his wing and introduced him to the radical Pan-African and socialist network of activistsorganizers in Harlem and Philadelphia. According to James, all who met Nkrumah were struck with his intellectual energy and acuteness, as well as his capacity to very quickly establish good relations in whatever company he found himself. ${ }^{89}$

\footnotetext{
87 Marika Sherwood. Kwame Nkrumah: The Years Abroad 1935-1947. (Legon, Accra, Ghana: Freedom Publications, 1996), 114.

${ }^{88}$ Kwame Nkrumah. Ghana: The Autobiography of Kwame Nkrumah. (New York: Nelson, 1957), 44.

${ }^{89}$ C.L.R. James, "Homage to Kwame Nkrumah.” Monthly Report: The Institute of Black World., Dabu Gizenga Collection On Kwame Nkrumah, box. 128-19, folder. 416.
} 
Recalling this time, Nkrumah stated: "I made time to acquaint myself with as many political organizations in the United States as I could. These included the Republicans, the Democrats, the Communists, and the Trotskyites. ${ }^{90}$ Nkrumah's aim was to learn the techniques and strategies of the organization for his eventual return home to the Gold Coast, which led to him to establish bonds with the likes of anti-colonial activists like Nnamdi Azikwe and Claudia Jones. Although he rarely formally joined organizations, Nkrumah regularly attended meetings with organizations of the Council on Affairs, the Committee on Africa, the Ethiopian Students Association, NAACP, the Committee on African Students, and the UNIA. By the later 1930s, Nkrumah was already a socialist and reading Marx, Engels, and Lenin for answers to the colonial question and the problem of imperialism. But Nkrumah admitted that while their philosophies sparked his revolutionary ideas and activities, the book that did more than any other to fire his enthusiasm was Philosophy and Opinions of Marcus Garvey. While Nkrumah's ideals of African Nationalism were heavily influenced by his former teacher James Aggrey, it was his introduction to Marcus Garvey's philosophy of "Africa for the Africans" that had the most profound influence on the centrality of Africa in the Black freedom struggle as well as his aspirations for an independent United States of Africa. ${ }^{91}$

Nkrumah and the West Indian Influence:

The West Indian community had a profound influence on Nkrumah from the moment he arrived in the United States. As a student at Lincoln, Nkrumah spent his summers in Harlem, where he lived with West Indian families and had a West Indian

\footnotetext{
${ }^{90}$ Kwame Nkrumah. Ghana: The Autobiography of Kwame Nkrumah. (1957), 44.

${ }^{91}$ Ibid, 45.
} 
girlfriend. Through his girlfriend, Edith, and his mentor CLR James, Nkrumah found himself immersed in West Indian social and political circles. Though he never danced at parties, he regularly attended West Indian social events here he would opt to converse on the struggle for independence in Africa. In addition to this, he regularly attended meetings of the Blyden Society, the UNIA, and the West Indian National Council. What all of these organizations have in common is that they were all West Indian oriented social and political organizations that were concerned with the welfare of all blacks in America.

If one were to operate in any political capacity in Harlem at this time, they would have to engage the strong West Indian community that had been putting down roots there for decades. By the 1930s, a third of the Black professionals and nearly a fifth of Manhattan's Black population were foreign-born and there were thirty West Indian mutual aid/benefit associations, as well as several social, literary, and sports clubs. ${ }^{92}$ As such, Nkrumah's time in Harlem, which coincided with the street corner orator culture that featured regular addresses from Richard B. Moore, Cyril Briggs, Marcus Garvey, and even Padmore. This setting profoundly shaped Nkrumah's views on Pan-Africanism, anti-colonialism, race, and nationalism prior to his journey to London.

What is clear is that Nkrumah's connections in the West Indian community in Harlem, particularly CLR James, were directly responsible for his entry into the PanAfrican movement in London. Had it not been for James' vast network, Nkrumah's transition to activist circles in London may not have been so smooth. Writing to Padmore in 1945, CLR James stated that: "George, this young man is coming to you. He is not

${ }^{92}$ Sherwood. Kwame Nkrumah. (1996), 39. 
very bright, but nevertheless, do what you can for him because he's determined to throw Europeans out of Africa. ${ }^{" 93}$ James recognized that while Nkrumah had a flair for applying Lenin's ideas on imperialism to his Pan-African sentiments, he still had much to learn. Thus, James presumably hoped Padmore was the ideal person for James to send him to, as his experiences as a journalist, organizer, and his interactions with the Soviet Union provided him with a network of global Africa and understanding of socialism that was unparalleled at the time. This was to be one of the great political associations of the twentieth century, as few at this time could have guided Nkrumah's political development better than Padmore.

In London, Padmore had arranged for Nkrumah, like most African students in London at the time, to stay at the West African Student Union (WASU) Hostel until he found permanent lodging. For a Black person in war-damaged London, finding permanent housing accommodation was no easy task. Nkrumah eventually found accommodation in the Tufnell Park area of northwestern London, which was about one mile from Padmore's flat in the Primrose Hill Garden neighborhood. It was in Padmore's small kitchen that Nkrumah refined his analysis of colonialism and imperialism and received the education on the practical side of mass organizing that would prepare him to achieve his aspirations for independence in the Gold Coast. Spending "much time" sitting at Padmore's "wooden table completely covered by papers," Nkrumah discussed politics, strategy, and tested the strength of his ideological positions with Padmore as well as Padmore associates passing through or living in London at the time. ${ }^{94}$

\footnotetext{
93 Ibid, 114

${ }^{94}$ Ibid, 116.
} 
Among these thinkers was Padmore's close friend and now General Secretary of the Pan-African Federation, T. Ras Makonnen. Nkrumah, now withdrawn from his anthropology program and pursuing a law degree, was actively discouraged from his academic pursuits. According to Makonnen, "we pooh-poohed the idea" of Nkrumah becoming a barrister. He further adds, "being a rebel was as good a profession as any...Lawyers take a constitutional approach... when one met him [Nkrumah], one could see that he would become some kind of leader; he had the mark on him." 95 This advice was pivotal to Nkrumah's development as he later discovered, upon his return to Ghana, that anti-colonial movements needed fulltime organizers that were free able to devote all of their time to mobilizing the people and securing independence. Furthermore, this same acute charisma, intellectual energy, and charm noticed by C.L.R. James in Nkrumah, quickly became evident, as his relationship Padmore's provided a seamless transition into the activist network in London and facilitated Nkrumah's mainstream introduction to the Pan-African movement.

Inspired by those like Garvey, Padmore, James, and Makonnen before him, Nkrumah initially intended to use his time in London to start a "fearless and militant newspaper" for the Gold Coast, that would promote African nationalism and revolutionize journalism in West Africa. ${ }^{96}$ However, by August of 1945, Nkrumah found himself "involved in manifold activities," such as participating in demonstrations and meetings called by WASU and PAF, addressing meetings of the Coloured Workers Association, and using his position as regional organizer of the Pan-African Congress to introduce himself to the prominent the Gold Coast nationalists of the time. Within the

\footnotetext{
${ }_{95}$ Makonnen. Pan-Africanism From Within. (1973), 154.

${ }^{96}$ Sherwood. Kwame Nkrumah. (1996), 120.
} 
year Nkrumah served as Vice-President of WASU, Secretary-General of the West African National Secretariat, and had already started his own "secret society," called The Circle. ${ }^{97}$

Among the many young African and West Indian student activists in London, Nkrumah must have stood out, as he was named Regional Secretary of Pan-African Federation shortly after he arrived in London. Serving in this capacity, Nkrumah was immediately brought on by Padmore to aid in organizing the Pan-African Congress in Manchester, which was set to take place just four months after Nkrumah's arrival in Britain. Seizing the moment, Nkrumah now the Regional Secretary of the PAF, began using his new position to strengthen his relationships with nationalists in the Gold Coast through his PAF announcements and invitations for the proposed Pan-African Congress later that year. ${ }^{98}$

\section{Manchester, 1945: A Meaningful Pan-African Congress}

When Amy Jacques Garvey and Harold Moody, founder of the LCP, approached Du Bois in 1944 about organizing the Pan-African Congress of 1945(erroneously called the fifth Pan-African Congress), their efforts resembled that of earlier Pan-African congresses in 1919, 1921, and 1927. These earlier Pan-African Congresses were largely limited to a privileged elite whose tactics were more accommodationists (requesting racial equality and reform in the colonies) as opposed to taking firm anti-colonial stances and demanding an end to colonialism and independent self-government. The earlier congresses were led and organized by an elite class who believed the educated Africans

\footnotetext{
${ }^{97}$ Ibid., 116.

${ }^{98}$ Ibid., 117.
} 
in the diaspora had a special role to play in the liberation of Africa because of their education and access to political power. In essence their proximity to whiteness. ${ }^{99}$ By 1945, these beliefs were not shared by the socialist leanings of Pan-African activists such as Padmore, James, and I.T.A. Wallace-Johnson, had been in direct contact, reporting on and mobilizing the workers of Africa and the diaspora for over a decade now.

At this time the elder statesman Du Bois, had no real ties to trade union and labor movements in the West Indies or the African continent, as most of his contact was confined to the elite class of African and West Indian intellectual-activists and diplomats living in the United States and Europe. ${ }^{100}$ As such, Du Bois was generally out of touch with the Pan-African movement, which was progressing at the local levels through strikes, boycotts, peaceful protests, and even riots. As a result, it was fitting that Padmore and the Pan-African Federation organized the Manchester Congress, because of their direct links to these grassroots organizations and nationalist movements.

The shift from the paternalism of the earlier Pan-African movement was marked by the emergence of African leadership and initiatives characterized by a collective of nations that would speak for themselves. More importantly, Pan-Africanism would be exercised through militant anti-colonial movements within the colonies as opposed to the European political forums of earlier Pan-African activism. This new generation of PanAfricanists, viewing colonialism as a child of capitalism, fascism, and imperialism, now made their Pan-African connection not only with race but also by linking the shared struggle of the exploited colonial laboring classes for the resources of Africa. Reflecting on the revolutionary mentality of these young Pan-Africanists and future nation-leaders,

\footnotetext{
${ }^{99}$ Von Eschen. Race Against Empire. (1997), 45.

${ }^{100}$ Plummer. Rising Wind. (1996), 156.
} 
the Pan-African Federation assumed the legitimacy of anti-colonialism and their quest for independence. Furthermore, they saw independence not something to be debated or patiently waited for, but rather as an as imminent outcome. This approach capsized the earlier strategies of Pan-Africanism that positioned the educated elite and more powerful African Americans as the stewards of Africa.

Initially, Du Bois expressed his disagreement with the plans of Padmore and the Pan-African Federation; however, through an exchange of letters, Du Bois and Padmore were able to have a meeting of minds and foster a close political collaboration that would continue in their shared mentorship of Kwame Nkrumah in Ghana. Through this correspondence, Padmore was able to convince Du Bois of the necessity of linking PanAfricanism to the nationalist labor movements in the African and West Indian colonies. Du Bois admitted that he was so out of touch with the rest of the African world that he had underestimated the sense of urgency among Africans and West Indians and their readiness for freedom. ${ }^{101}$ By this time it was not the UNIA's Negro World nor the NAACP's Crisis magazine that was intimately in tune with the collective plight of people African descent, rather it was the Pan-African Federation, previously the IASB, that built up an unparalleled network disseminated updates to the African world. Padmore drove the point home telling Du Bois that "Today the African masses, the common people of are awake and not blindly looking to doctors and lawyers to tell what to do." ${ }^{102}$ Those participating in this congress would not be bourgeois professionals of past congresses, but rather from the workers' organizations, peasant associations, labor parties, and nationalist organizations from the colonies. In the end Du Bois found the new socialist

\footnotetext{
101 Plummer. Rising Wind. (1996), 155.

102 Adi. Pan-Africanism: A History. (2018), 124.
} 
influenced Pan-Africanism in London resonated with his own ideas about politics and economics, and he endorsed the Pan-African Federation's plans for the congress.

Furthermore, the decision to hold the congress in Manchester also reflected the significance of Communism to Pan-Africanism. In organizing the congress, the PanAfrican Federation intentionally took advantage of the World Federation of Trade Unions (WFTU) conference being held in London. This particular WFTU conference was expected to feature unprecedented participation of West-African delegates and African trade unionists from the British colonies, which ultimately caused the Pan-African Federation to agree to hold the Pan-African Congress in Manchester as opposed to Paris. Manchester was also fitting as it was the site of the founding of the Pan-African Federation in 1944. Makonnen had relocated to Manchester where he had already established a number of restaurants, which instantly solved the issue of the color bar. Additionally, through local contacts, Makonnen was able to secure Chorlton Town Hall as a venue for the congress. There was also, according to Henry Lee Moon, director of Political Action Committee of the Congress of Industrial Organizations (CIO), a large interest from colonial labor groups for the congress to take place in Manchester. Moon confirmed the Pan-African Federation's prediction that African and West Indian participants in the WFTU expected to return for this Congress and felt that they could represent their organizations both at the Labor meeting and at the Pan-African Congress. ${ }^{103}$

Additionally, correspondence between Moon and Du Bois demonstrated the apprehension that the older generation of Pan-Africanists held towards the Congress

\footnotetext{
${ }^{103}$ William Edward Burghardt Du Bois and Herbert Aptheker. The Correspondence of WEB Du Bois. (Amherst: University of Massachusetts Press, 1997), 58.
} 
because of its socialist undertones and focus on labor. Moon suggested that Moody doubted the wisdom of relating the Congress to the labor movement and believed "that there should be no correlation between the Pan-African Congress and any other organization or movement." ${ }^{104}$ It must be remembered that it was Moody who initially proposed the Congress to Du Bois, and his uneasiness regarding the labor focus of the Congress further demonstrates the departure from the more conservative earlier congresses. In spite of Moody's apprehension, the 1945 congress went on to feature eighteen colonial trade unions and twenty-five cultural and political organizations. While the French and Arab North African colonies were lacking in representation, it was still the first time that Africa was adequately represented at a Pan-African Congress.

Officially commencing on October 15, 1945, the congress was presided over by Du Bois and Peter Millard, the President of the Pan-African Federation. Taking place at Chorlton Town Hall, the venue was outfitted with the national flags from Ethiopia, Haiti, and Liberia, the only three predominantly Black nations possessing their own independence at the time. Topics discussed featured condemnations of the colonial systems, the hypocrisy of the Atlantic Charter, racial discrimination, and above all independence. "Imperialism in North and West Africa" was the subject of discussion on the second day of the congress. It was here that Nkrumah, serving as co-political secretary with Padmore, made his mainstream debut on the Pan-African and African nationalist scene. Nkrumah outlined the political and economic conditions in these regions and attributed the cause of the major problems that had manifested there to colonialism. Sessions on Southern and Central Africa where conducted by Peter

\footnotetext{
${ }^{104} \mathrm{Du}$ Bois and Aptheker. Correspondence of WEB Du Bois. (1997), 58.
} 
Abrahams and Marko Hlubi, while Jomo Kenyatta delivered an official report on East Africa. Makonnen, secretary of the PAF, was given the responsibility of providing a report on "Ethiopia and the Black Republics," which accused the British government of plotting with Italy to expand its empire into Ethiopia. The report on the west Indies was delivered by Padmore, who outlined the history of the Caribbean from Columbus' first encounter with the region up unit the Emancipation Act of 1833.

The five days of discussions culminated in the adoption of several resolutions and demands including immediate independence in all European colonies; comprehensive constitutional, economic, and social reform; the introduction of modern social legislation, old-age pensions, national health, and compulsory free education at elementary and secondary school levels. ${ }^{105}$ In addition to this, the congress included in their demands a unified condemnation of capitalist imperialism to the United Nations; formally opposed the racial discrimination at the root of legislation in the Union of South Africa; and identified with the struggles of their "brothers" in the United States for full citizenship. The Congress also challenged the Colonial powers to honor the principles of democracy espoused in the Atlantic Charter, specifically its third clause that claimed to respect the rights of all peoples to choose the form of government under which they will live and desire to see the sovereign rights and self-government restored to those who had been forcibly deprived of them. The mention of the rights of self-government of all people spoke directly to the anti-colonial struggles taken up by the Pan-African movement emanating from London.

${ }^{105}$ Esedebe. Pan-Africanism. (1994), 143 
Finally, the Congress declared that while they believed in the Positive Action of peace, as victims of European violence and slavery, their last resort for achieving freedom would appeal to violent force, even if it destroyed themselves and the world. ${ }^{106}$ Reiterating how imperative workers and farmers were the anti-colonial struggles, the Congress also issued a "Declaration to the Colonial Workers," imploring them to organize and reminding them that: "Your weapons - the Strike and the Boycott - are invincible!" 107 Nkrumah claims to have written one or two of the resolutions; however, scholars suggest that the resolutions were more likely written by Padmore and veteran intellectual-activists in attendance from London.

This Pan-African congress also differed from past meetings for a number of reasons. First, because for the first time African and West Indian participants came not as individuals but as delegates from organizations representing the masses of African workers. No longer was the Pan-African Congress movement under the direction of middle-class African American intellectuals with little to say on the African and West Indian workers. Second, Amy Ashwood Garvey addressed the congress and emphasized the significance of women as a topic of discussion, reminding the majority male delegations that "for some reason very little had been said about the Black woman...[whom] have been shunted into the social background to be a child-bearer." Finally, the Congress suggested that "there is but one road to effective action - the organization of the masses. And in that organization the educated colonials must join." 108 The unequivocal demands and harsh criticisms of the Congress were augmented by the

\footnotetext{
${ }^{106}$ Padmore. Pan-Africanism or Communism. (1971), 148.

${ }^{107}$ Esedebe. Pan-Africanism. (1994), 144.

${ }^{108}$ Adi and Sherwood, The 1945 Manchester Pan-African Congress, 55-56, quoted in Adi. Pan-Africanism: A History. (2018), 126.
} 
Congress' emphasis on the necessity of the struggle for independence to take place, not in the European metropole, but in the colonial homelands. A clear departure from the accommodation approach to past Congresses was demonstrated in the Manchester Congress' view that independence must be fought for in the colonies and for the first an appeal to use force to achieve freedom was proposed.

Following the Manchester congress, Du Bois was named the president of the PAF along with Nkrumah serving as the Secretary of the Working Committee. Serving as a Congress official and now a secretary of the PAF, Nkrumah quickly gained a high profile in Pan-Africanist circles. Charged with establishing a new headquarters for the PAF and maintaining correspondence with delegations from the Congress, Nkrumah began signing PAF documents as the Secretary of the Federation's International Secretariat. In his initial communications, Nkrumah asked that all organizations and individuals that participated in the Congress now officially affiliate themselves with the PAF, and pledged to "do everything in my power to make this organization an effective weapon in the fight for Colonial Freedom and Justice." 109 With Du Bois as a ceremonial president, Nkrumah, who had been included in private strategy meetings and deliberations leading up to the Pan-African Congress, with the PAF. Equipped with Padmore's contacts, counsel, and his own increasing Nkrumah was poised to place his own organizing and agitating skills on display.

The following year, the Pan-African Federation, organized a petition to the United Nations stating that the Federation's aim was to establish freedom and political autonomy for African peoples. The petition also asserted that the Pan-African Federation "had far-

\footnotetext{
${ }^{109}$ Sherwood. Kwame Nkrumah. (1996), 123.
} 
reaching and increasing influence among negroes and has especially brought people of negro descent in the Americas into sympathy with their African brethren." ${ }^{\prime 10}$ In essence, this petition emphasized the linking of the anti-colonial struggles Africans in the West Indies and the African Continent to the struggle for Civil Rights of Africans in the United States. The United Nations and the world were now on notice that Pan-Africanism was stronger than ever, and the issue of colonialism would have to be reconciled in the near future.

In the early twentieth century, London stood as the epicenter of the Pan-African resistance for the colonial world. London was a place where the varying identities of people of African descent, mostly from the British colonies, converged and were linked by their shared experiences with colonial rule, color bar in London, the betrayal of the Comintern and national labor parties, as well as the fascist invasion of Ethiopia that was seemingly sanctioned by the European powers. Pan-Africanism became the only viable political ideology for the splintered Black organizations in London to combat the multiple demonstrations of Pan-Europeanism on display in the early twentieth century.

The failures, illegitimacies, and betrayals of communism, socialists, and British colonialism reinvigorated the Pan-African movement in London, where the British government ironically saw the ideology taken up, revolutionized, and deployed as a critical analytical framework by intellectuals educated in colonial institutions. PanAfricanism had been an idea, a theoretical framework, and a source of hope, but now the time for ideas had passed. This cohort of intellectual-activists had similar experiences with colonial rule and in London. Padmore, James, Lewis, and Makonnen had used Pan-

${ }^{110}$ Von Eschen. Race Against Empire. (1997), 53. 
Africanism as the basis for their speeches, criticisms, propaganda against the colonial system, and for mobilizing people of African descent on an international scale. As colonial officials feared, the unrest in the West Indies and Africa had been linked, dialogued with each other, and organized for a coordinated assault on the colonial system. There was nothing left to propose, reform, or illuminate for colonial administrations, the League of Nations, or the Comintern. With independence on the horizon and Kwame Nkrumah primed to lead a revolutionary movement against British colonialism in the Gold Coast, the time had come for Pan-Africanism to be more than an idea. The time had come for Pan-Africanism to become praxis. 


\section{GEORGE PADMORE, PAN-AFRICAN SOCIALISM, AND THE CONTOURS OF AFRICAN NATIONALISM}

In 1934 when George Padmore resigned from his position as a member the Communist International's Higher Council, he maintained that his resignation took place on his own accord, and that "the real question involved [was] one affecting fundamental democratic rights of the Negro peoples in their relationship with the revolutionary movement and therefore of vital importance not only to the twelve million Negroes in the United States but to the two hundred and fifty million Blacks in Africa and other colonial lands." 111 Padmore was sure to take his contacts from Africa and the diaspora with him after he resigned and rededicated his anti-colonial objectives to the Pan-African movement. In doing so, Padmore facilitated the resurgence of the Pan-Africanism for the final assault on European colonialism.

As a result of his prominence in London activist circles, Padmore became a mentor to a generation of Pan-Africanist that came of age during the Inter War years. Among these young Pan-Africanist was Kwame Nkrumah, who served as Padmore's understudy in London and relied upon his counsel in the Gold Coast as he secured independence from British Colonialism and laid the foundations for Ghana's Pan-African Policy to liberate the rest of the African continent. Through an examination of Padmore's tenure with the

\footnotetext{
111 "Why I Left The Communist International - Padmore Refutes Lies And Slanders Of Communists." February 13, 1934, George Padmore Collection, box 1, folder 2; Special Collections, Princeton University Library.
} 
Soviet Union, mentorship of Nkrumah, his strategies for navigating the British Colonial Government and Ghanaian opposition to Nkrumah to achieve independence, and his contributions to ideological direction of post-colonial Ghana, this chapter argues that Padmore was the vital to the success of Ghana's independence, as well as Nkrumah's most influential advisor as Ghana became a base for Pan-African liberation.

\section{Pan-Africanism or Communism?:}

The Pan-African Movement that emerged in the 1930s was first and foremost an anti-colonial movement. In the wake of the great depression and with another world war on the horizon, many Black intellectual-activists in London found their defining ideology in the critical analysis of socialism. While the philosophy of Communism was developed by Karl Marx, a German, it was Nikolai Lenin, the father of Bolshevism and the leader of the Russian Revolution, who appropriated Marxism and extended it to include the millions of racial minorities, peasants, and non-Russian nationalities of Asia, particularly China. It was this sense of racial equality and anti-colonialism that attracted many African intellectuals to Russian Communism. Black Marxists were quickly recruited from the African Diaspora to study in Russia and to join the Communist Parties of Britain, the United States, and France under the guise of a political ideology that espoused racial equality and true democracy for a world revolution. One of these Black intellectuals was Trinidadian journalist, organizer, and Pan-Africanist, George Padmore.

Born Malcolm Ivan Nurse in 1902, Padmore, joined the Communist party while pursuing his undergraduate degree in the United States. Under the name "Padmore" he went on to speak on communist platforms, serve as a revolutionary journalist writing for several communist press outlets, and established himself as a skilled organize, recruiting 
several West Indian and African students (mainly from British dependencies) into the party. Showing great promise in his work with the Communist Party in the US, Padmore was recruited to work in Moscow in 1929, where he quickly rose in the ranks of the Communist International and was made the head of the Negro Bureau of the Red International of Labor Unions (RILU), secretary of the International Trade Union Committee of Negro Workers (ITUCNW), and by 1931 he served as editor of the Negro Worker magazine.

The International Trade Union Committee of Negro Workers (ITUCNW) was established by the RILU in 1930 with the main objective of providing "a picture of the life and struggles of the Negro workers" to establish revolutionary trade unions throughout African, the West Indies and elsewhere. ${ }^{12}$ For Black communists at this time, the ITUCNW and its journal, the Negro Worker, reflected the potential that many of them saw in the Comintern. Analyzing and linking the day to day problems of Black workers, the Negro Worker was widely distributed in the English and French colonies of West Africa, South Africa, Brazil, and The United States.

By 1932 Padmore began to slip from the Comintern's control as he began to pursue more independent organization initiatives that went far beyond the initial plans for the ITUCNW. Instead of parroting Marist theory, Padmore published articles and reports that covered labor movements, strikes and uprisings, and organizations established throughout colonies in Africa and the West Indies. Within a year of heading the Negro Worker, Padmore had far exceeded expectations when he reported to the Comintern that he had expanded the international contact list of the ITUCNW from a mere sixty contacts

\footnotetext{
${ }^{112}$ Adi. Pan-Africanism and Communism. (2013), 132.
} 
to "thousands of new connections" in Africa including the Gambia, Senegal, Sierra Leone, Gold Coast, Nigeria, South Africa, Belgian Congo, Kenya, Uganda, Tanganyika; in the West Indies including Jamaica, Haiti, Barbados, Trinidad, Grenada, St. Lucia, the Virgin Islands, Bermuda, Guyana, Panama, Honduras; and hundreds of contacts in the United States, England, England, and France. Most of these contacts were established through Padmore's extensive and unauthorized travels through West Africa as well as through written correspondence with trade unions and local organizers in these nations. He also disregarded Comintern protocol as he began sending independent organizers to Africa and the West Indies who were not communists to help radicalize Black workers. By using Comintern resources to fund his pursuits in organizing blacks regardless of class or political affiliation, Padmore had begun organizing a Pan-African network for future action.

Subsequently, Padmore found that national communist parties were reluctant to aid Black communists in nations across Europe and the United States. His growing frustrations with the Comintern eventually led him to question its policies, their effectiveness, and Moscow's ability to compel local parties to take anti-colonial work seriously. Furthermore, while Padmore had extended the reach and influence of the Communist International among Blacks as far south as South Africa and as far west as British Guiana, he would eventually be expelled from the Comintern because of his "nationalist deviations." 113 Being constantly reprimanded for his narrow focus on "The Negro Question" and turning the ITUCNW into a de facto Pan-African division of the Comintern, Padmore resigned from the Comintern and took his contacts from Africa and

\footnotetext{
${ }^{113}$ Makalani. In the Cause of Freedom. (2011), 193.
} 
the diaspora with him. In spite of his smearing in communist print media, Padmore maintained that he had, in fact, resigned from the Comintern on his own accord, and that "the real question involved [was] one affecting fundamental democratic rights of the Negro peoples in their relationship with the revolutionary movement and therefore of vital importance not only to the twelve million Negroes in the United States but to the two hundred and fifty million Blacks in Africa and other colonial lands." 114

In addition to his struggles working within the upper levels of the Comintern, Padmore and several Black Marxists faced what he called, "Imperial Socialism," as they found that many European communists opposed anti-colonialism and embraced the necessity of European colonialism to their own economic survival. ${ }^{115}$ In his text PanAfricanism or Communism, Padmore quotes German socialist, Dr. Eduard David in 1928 who argued: "Europe needs colonies she does not even have enough. Without colonies from an economic point of view, we shall sink to the level of China." 116 For David, Europe's reliance on its colonies for economic survival transcend the Lenin Thesis' call for crippling western domination through an all-out assault on colonialism, which was the source of their economic dominance and necessitated inhumane racial oppression, particularly in Africa and the West Indies.

The fact that Dr. David's comments were endorsed by members of Communist parties in Britain, France, Belgium, and Portugal, all prominent colonizers of Africa and the West Indies, suggested that national communist parties had no interest in remedying

\footnotetext{
114 "Why I Left The Communist International - Padmore Refutes Lies And Slanders Of Communists." February 13, 1934, George Padmore Collection, box 1, folder 2; Special Collections, Princeton University Library.

${ }_{115}$ Padmore. Pan-Africanism or Communism. (1971), 299

116 Ibid., 298-299.
} 
European colonialism, or what Marx described as the "profound hypocrisy and inherent barbarism of bourgeois civilization."117 Furthermore, at the root of all of Padmore's politics was his mission to realize a free and independent Africa. This collective disregard for anti-colonial struggles amongst national communist parties and their inability of national and local communist parties to rid themselves of their racial chauvinism caused a number of Black communists to drift away from Communist organizations, opting to form their own socialist organizations concerned specifically with the welfare of people of African descent.

The second major issue that arose for Padmore emerged on the subject of the Soviet Union's foreign policy leading up to World War II, particularly on the question of anti-imperialism and Stalin's budding alliance with imperialist western nations against the rising current of fascism. Prompted by the rise of fascism in Germany the disagreements with the Comintern who differentiated between the imperialism of Britain, France, the United States and the fascist imperialism of Germany, Italy and Japan. For Padmore, these countries embodied the evils of capitalism, imperialism, and racism that people of African descent had been subject to in modern history. In response to this request, he pointed out that neither Germany nor Japan had colonies in Africa, and that the USA, where he attended university in the Jim Crow South, was the most raceprejudiced country in the world.

To acquiesce to these two ideological stances of the Comintern for Padmore, was tantamount to sacrificing the fundamental interests of his people and the ongoing liberation movements taking place in Africa and the West Indies. This was a betrayal

\footnotetext{
${ }^{117}$ Karl Marx. "The Future Results of British Rule in India," New York Daily Tribune, August 8, 1853.
} 
with which he could not identify himself. Padmore refused to trade his European colonial masters for Russian ones and was left with no choice but to sever his connection with the Communist International in 1934. After risking his life to retrieve his contacts of revolutionary movements in Africa and the diaspora from the Hamburg, Germany office of the ITUCNW, Padmore made his way to London where the revitalization of the Pan-African movement and the final assault on colonialism was set to take place.

First Encounter: Padmore, Nkrumah and the Manchester Congress

From the moment Padmore arrived in London he became active in political organizing. Padmore was rather liberated in this new capacity as he was able to organize and strategize for African liberation without the restraints placed upon him by the Comintern. In a short time, Padmore found himself at the center of Black political organizing in London and became one of the most widely known revolutionary journalists throughout the British empire. Because of this, Padmore quickly became a mentor for African and West Indian students studying in London. Of the young generation of futures leaders under Padmore's tutelage, by far, his most prized student was Francis Nkrumah. Upon his arrival in London, Nkrumah, according to Peter Abrahams, "was concerned with one thing, getting power and getting it quickly."118 Nkrumah came to London with passion and ideas, but no concrete knowledge of how revolutionary movements for power were organized and facilitated. According to CLR James, Nkrumah would not find a better teacher than Padmore, as he was one of the most highly educated and experienced political figure in the world," having worked with

\footnotetext{
118 Peter Abrahams, "Nkrumah, Kenyatte and the Old Order," in African Heritage, edited by Jacob Dracher, (New York: Crowell-Collier, 1963); and 'Last Word on Nkrumah,' West African Review October 1954, 913, in Sherwood, Marika. Kwame Nkrumah. (1996), 160.
} 
the Communist in the United States, the Third International in Moscow, and founding his organizations in London. ${ }^{119}$ For this reason, Nkrumah spent "endless hours discussing colonial issues" with Padmore gaining a political education on the techniques of organizing. These discussions with Padmore would last into the early hours of the morning in the company of activist intellectuals like T. Ras Makonnen, Jomo Kenyatta, CLR James, Peter Abrahams, and Richard Wright. Through this group, Nkrumah was introduced to the London activist scene and proved himself an over ambitious yet competent intellectual-activists, which prompted Padmore to bring Nkrumah on as a key organizer for the Manchester 1945 Pan-African Congress.

The congress focused primarily on Africa, anti-colonialism, and unity, all of which directed the trajectory of Pan-Africanism in its aftermath. Emerging from the Congress as the Secretary of the Working Committee of the Pan-African Federation, Nkrumah, now going by Kwame, had acquired a high profile and became a prominent name among the vast network of Pan-Africanist, trade unionists, and African nationalists. Noting that the conference featured the largest attendance of representatives from African in the history of the Pan-African Congress movement, C.L.R. James noted that finally, Africans became to assume the roles of leadership that had previously belonged to West Indians.

Nkrumah corroborated James' observation shortly after the Congress when according to his account, he had been approached by several politically active Africans living in London at the time to establish and organization with the focus of putting "into

${ }^{119}$ C.L.R. James. "Kwame Nkrumah: Founder of African Emancipation." (Black World 21, no. 9 1972), 6. C. L. R. (Cyril Lionel Robert) James Papers; box 9, folder 9; Rare Book and Manuscript Library, Columbia University Library. 
action the new Pan-African nationalism, with particular reference to West Africa and with the object of calling a West African National Congress and of directing the program of self-government for the West African colonies, British as well a French.”120 The result was the founding of the West African National Secretariat (WANS), with the primary objective of maintaining contact, coordinating, educating, and supplying information on current matters to various political bodies, farmers organizations, cooperative societies, educational, cultural and other progressive organizations in West African to realize a West African front for a United West African National Independence. Now calling for unity, the liquidation of the colonial system in West Africa, and with support in West Africa, the United States, Britain, and France, Nkrumah made use of his new contacts by holding a joint conference with WASU on "Unity and Independence of All West Africa" in 1946, and making plans for an All-West African National Congress to take place in Lagos, Nigeria in 1948.

While Nkrumah suggests WANS was birthed from the deliberations of the Manchester Congress, Padmore disagreed with three components of the organization. First, the organization's focus on West Africa, in Padmore's view, was regionalism and tantamount to tribalism, which he believed ultimately worked against the aims of PanAfricanism to free the entire continent. For Padmore, whatever was birthed from the Congress should embrace the entire continent of African and not a particular sub-region; however, Nkrumah believed West Africa as a unit was more manageable. Second, within WANS, Nkrumah found his secret society, called "The Circle," in which members of the members took blood oaths of secrecy as well as loyalty not only to Pan-Africanism or

${ }^{120}$ Adi. Pan-Africanism: A History. (2018), 129. 
African liberation but also to formally accept the leadership of Nkrumah himself. Nkrumah saw himself as a man of destiny and purely believed in the role he would play in the liberation of Africa. Within the Circle, lay the seeds of Osagyefo/Nkrumaism, the personality cult that he would later develop in Ghana, which Padmore carefully monitored in his struggle to contain Nkrumah's growing vanity. In addition to this was the fact that Nkrumah began to neglect his duties as Secretary of the Pan-African Federation following his involvement with WANS and the Circle, which Sherwood suggests were mere vehicles to promote his ego and personal ambitions.

Third, Padmore believed WANS to be too sympathetic to communism and viewed Nkrumah's growing association with the Communist Party of Great Britain and British left-wing labour politicians such as Arthur Creech Jones, Rita Hinden, and Fenner Brockway, as a possible ploy by communists to influence West African politics for their own ambitions. ${ }^{121}$ Subsequently, WANS was heavily influenced by the Marxism of the Communist Party of Great Britain, and held an objective of establishing a "Union of African Socialist Republics." 122 Padmore's own experiences with the opportunism of the USSR and its sole desire of appealing to people of African descent merely to bolster their numbers caused his abhorrence of communism. Padmore's concerns were not unfounded, as his concerns about European communists and his notion of "Social Imperialism" were corroborated at a Labour Party and Fabian Colonial Bureau conference on colonialism in January 1946. The Fabian Society was socialist organization that sought to reform British society through gradualism and democratic means rather than through revolution.

\footnotetext{
${ }^{121}$ Ama Biney. The Political and Social Thought of Kwame Nkrumah. (New York: Palgrave Macmillan, 2011), 35.

${ }^{122}$ Adi. Pan-Africanism: A History. (2018), 132.
} 
Following a speech given by Nkrumah, Rita Hinden, the Bureau's secretary stated: 'when Mr Nkrumah said "we want complete independence" it left me absolutely cool... British socialists are not so concerned with ideals like independence and self-government, but with the idea of social justice. When British socialists look at the Eastern Europe of today they as whether independence is itself a worth-while aim. ${ }^{123}$ Also, the discovery of communist pamphlets and the absence of literature on Pan-Africanism in the WANS headquarters, along with its member forming an African sub-committee within the Communist Party of Great Britain, a rift a was created between Padmore and Nkrumah that would persist until his death.

Nonetheless, Nkrumah and WANS continued working with Padmore and the PanAfrican community. They publicized each other's meetings and events, their publications feature the other's writing, and Nkrumah even protesting the colonial government's confiscation of Padmore's book, How Russia Transformed Her Colonial Empire in the Gold Coast. For Padmore's part, as Nkrumah's notoriety grew in Britain and African Nationalist circles, he continued to mentor and work closely with Nkrumah. Because of his work with WANS, the Pan-African Federation, the 1945 Manchester Pan-African Congress, and his position as "associate and contributing editor" of the Pan-African Federation's publication, Pan-Africa, Nkrumah quickly became a prominent figure in international socialist, trade union, Pan-African, and anti-colonial circles. As a result, in September 1947, Nkrumah received a letter from the United Gold Coast Convention (UGCC), inviting him to serve as its General Secretary with a salary of one hundred pounds a month and a car.

\footnotetext{
${ }^{123}$ Rita Hinden quoted in R.S. Gupta, Imperialism and the British Labour Movement 1914-1964, (London: Macmillan, 1974), 326.
} 
After initially acquainting himself with the Gold Coast political landscape, Nkrumah found himself ideologically opposed to the notion of a "movement backed almost entirely by reactionaries, middle-class lawyers and merchants." ${ }^{124}$ This prompted him to consult his mentor Padmore who advised Nkrumah to accept the offer from the UGCC. Nkrumah left for the Gold Coast on November 14, 1947, and to his surprised was received by the immigration officers with warm enthusiasm and an apparent reputation that preceded him. Now home for the first time in over a decade, Nkrumah had the opportunity to use the political education and organizing skills that he received from his mentor Padmore, as well as from his experiences in London and the US into practice, notwithstanding the challenges that were ahead of him in the Gold Coast. In doing so Nkrumah placed himself in the tradition of Pan-African Gold Coast Nationalists that preceded him, like Kobina Sekyi and J.E. Casely Hayford. The more prominent of these men, Casely Hayford, was regarded by Padmore as "undoubtedly the greatest national political leader and social reformer West Africa had yet produced" and "a sort of John the Baptist, preparing the way for younger nationalist leaders like Kwame Nkrumah." 125

\section{Padmore's Organizing Model in The Gold Coast}

Padmore's influence on Nkrumah was immediately placed on display in the Gold Coast, as he deployed three organizing techniques and political concerns to build a

\footnotetext{
${ }^{124}$ Biney. The Political and Social Thought of Kwame Nkrumah. (2011), 35.

${ }^{125}$ George Padmore. The Gold Coast Revolution: The Struggle of An African People From Slavery to Freedom. (London: D, Dobson, 1953), 52.; Similar to Nkrumah, J.E. Casely-Hayford's politics of African nationalism were influenced by West Indian Pan-Africanists like Edward Wilmont Blyden and Marcus Garvey, particularly in their conceptions of the African personality and Pan-African Nationalism. For more on this see: Kwadwo Osei-Nyame. "Pan-Africanist ideology and the African historical novel of selfdiscovery: the examples of Kobina Sekyi and JE Casely Hayford." (Journal of African Cultural Studies 12, no. 2 (1999): 137-153.)
} 
nationalist movement and secure political power as the next phase of Pan-Africanism in Ghana. As discussed in the previous section the organizing techniques used by Padmore and observed by Nkrumah were the inclusion of the broad masses, a focus on education of the youth on Pan-African socialism, and the promotion and propaganda on Positive Action. There were also three political concerns in which the two had certain nuanced disagreements: (1) nationalism, tribalism, and regionalism; (2) personality cult and Nkrumaism; and (3) the usages of communism for African liberation. The concerns posed the largest challenges Nkrumah would face as he attempted to achieve independence in Ghana, while emphasizing Pan-African unity as fundamental to the movement.

In the Gold Coast, Nkrumah entered a British colony with a strong culture of political activism and nationalism that had been dominated and conducted primarily in the interest of Traditional leaders and the African educated elites, specifically wealthy lawyers and entrepreneurs. Since these professionals and businessmen were too busy with their professional endeavors, Nkrumah was recruited to devote his proven organizing skills to building a strong nationalist movement in the Gold Coast on a fulltime basis. Before his arrival, the leaders of the UGCC, many of whom were educated in Britain, envisioned ending colonial rule, with themselves naturally assuming the positions of leadership formally held by British colonial administrators. Although Nkrumah initially opposed the social makeup of the UGCC, he quickly changed the focus of the organization and its movement, as he immediately set out to create a broad national movement, based on the theoretical knowledge and pragmatic tactics that he learned during his time abroad with Padmore and other Pan-Africanists. 
Upon his arrival in December 1947, Nkrumah found that the UGCC had about 13 branches, consisted of African elites, like J.B. Danquah and Ebenezer Ako Adjei, that "got together, talked, wrote and published a few documents, but the mass of the population did not seem to them the people who should be the basis of the political party." 126 As a result, Nkrumah set about transforming the UGCC into a strong nationalist movement based on the organizing model he witnessed among the Padmore and the West Indians leading the Pan-African movement in London. Similar to Padmore's emphasis on organizing a broad membership that transcended class identifications, so too did Nkrumah in his deliberate restructuring of the UGCC. Noticing that the organization "lacked any kind of program or mass organization," Nkrumah expanded the UGCC's appeal beyond the interests of the Gold Coast elites, but to include the farmers, petty traders, drivers, artisans, school teachers, clerks, and market women throughout the entire territory of colony. He sought to build a mass movement, revise the UGCC's objectives, restructure the organization's infrastructure, and consolidate the colony's youth under the UGCC.

\section{Focus on the Youth:}

Just as Padmore worked consolidate the African and West Indian student organizations and the various Pan-African organizations in Britain under the Pan-African Federation, Nkrumah, sought to derive the energy for his nationalist movement from the Gold Coast's youth. This resulted in the amalgamation of a number of youth societies in Gold Coast under the UGCC, as a de facto youth section, called the Committee of Youth Organizations (CYO). This youth element within the UGCC brought with them a radical

\footnotetext{
126 “Kwame Nkrumah: Founder of African Emancipation.” (1972), 6, C.L.R. James Papers, box 9, folder 9.
} 
and progressive approach to anti-colonial politics. The amalgamation of the youth organizations also served to broaden the Gold Coast's nationalist movement. Also, independent schools were established to strengthen the nationalist movement by providing ideological and political education for the broad masses. The schools were formed following the expulsion of several students and teachers in the city of Cape Coast for striking in protest of the arrests of Nkrumah and other political leaders in July 1948. ${ }^{127}$ The news of the foundation of these UGCC independent schools dozens of schools were founded and operated out of party branches in the southern Gold Coast. ${ }^{128}$ Furthermore, Nkrumah established 500 UGCC branches throughout the colony within six months of his return home. These successful nationalist initiatives did not jive well with the rest of the UGCC leadership.

Following Nkrumah's arrest due to his role in an ex-servicemen's demonstration and a boycott of European goods, that led to the 1948 riots in the Gold Coast, a rift was created between Nkrumah and the rest of the UGCC's Working Committee. During his detainment, British colonial authorities accused Nkrumah of being a member of the communist party and interrogated him on his political views. Nkrumah maintained that while he subscribed to some of their views, he was never a member of the party, rather he was a Pan-Africanist and Marxist socialist that desired self-government and West African unity. ${ }^{129}$ The UGCC leadership had been skeptical of these same rumors surrounding Nkrumah, as his aspirations for West African unity during his time with WANS and the use of the term "comrade" concerned them from the outset. Although Nkrumah astutely

\footnotetext{
127 Jeffrey S. Ahlman. Living with Nkrumahism: Nation, State, and Pan-Africanism in Ghana. (Athens: Ohio University Press, 2017), 54

128 "Kwame Nkrumah: Founder of African Emancipation.” (1972), 6, C.L.R. James Papers, box 9, folder 9.

${ }^{129}$ Biney. The Political and Social Thought of Kwame Nkrumah. (2011), 37.
} 
assured them that he "believed in TERRITORIAL BEFORE INTERNATIONAL solidarity," the UGCC remained ambivalent towards Nkrumah, hoping to use him to achieve their own goals in fear of what he might achieve without them. ${ }^{130}$ Ultimately, in the month following his detainment, the UGCC leadership demanded Nkrumah's resignation accusing him of being a communist and denouncing the youth that Nkrumah had brought into their ranks as malcontents and agitators.

Nkrumah's resignation caused a split between the UGCC and the CYO, which led to a mass exodus this radical element out of the party and the formation of Nkrumah's Convention People's Party (CPP) in June 1949. The emergence of the CPP reflected a clear departure from the UGCC's gradualist, conservative approach to anti-colonialism in the Gold Coast that called for "Self-government within the shortest time possible." The older establishment representing the chiefs, the wealthy merchants, and educated elites in the Gold Coast, witnessed Nkrumah take with him the extensive system of branches that he had amassed during his short tenure. Standing in direct ideological opposition to the UGCC, the CPP represented an impatient radical party that rejected the accommodationist approach of their elders and demanded: "Self-Government NOW!" The formation of the CPP also represented, to the UGCC, a political betrayal by Nkrumah, whom they financed and invited into their movement, only to have him use their resources to amass his party.

\section{The Masses Choose Nkrumah}

Now with his party, and in his homeland, Nkrumah was equipped with the unrestricted means to carry out his plans for self-government. He wasted no time

${ }^{130}$ Ibid., 38. 
implementing the populist movement model that he had observed in London. Central to the CPP was its focus on building a movement for the masses. The CPP quickly became the "commoner's party," creating a space for the interests of the semieducated, illiterate, working masses to be represented in national politics. The CPP quickly grew into a populist-nationalist movement comprised of the urban and rural, elite intellectual class and the working masses - farmers, petty traders, drivers, artisans, school teachers, dockworkers, and market women. ${ }^{131}$ Reflecting on the resolutions of the Manchester 1945 Congress' call for the African masses to lead the fight for African liberation, CPP looked upon the masses as autonomous citizens that were capable of making their own rational choices and representing themselves.

The Gold Coast masses made their intentions clear in November 1949 when Nkrumah, in association with the Trade Union Congress, convened the Ghana Representative Assembly. The first of its kind, the assembly was attended by an estimated 80 thousand people with representatives from over fifty organizations, including trade unions, co-operatives, farmers' organizations, educational, cultural, women's, and youth bodies. ${ }^{132}$ The only groups of Gold Coast society that were not in attendance were the UGCC and the chieftain councils. To complement this mass mobilization, Nkrumah drew on Padmore's teachings by accompanying the founding of his political organization with its propaganda vehicle. Just as the ITUCNW had the Negro Worker, and the Pan-African Federation had Pan-Africa, the CPP had the Accra Evening News. Nkrumah established the Evening News in September 1948 to act as the chief voice of the masses and critic of British colonialism in the Gold Coast. Having observed the use of print media by West

\footnotetext{
${ }^{131}$ Matteo Grilli. Nkrumaism and African Nationalism. (New York: Palgrave Macmillan, 2018), 50

${ }^{132}$ Padmore. The Gold Coast Revolution. (1953), 72.
} 
Indian intellectual-activists like Garvey, Padmore, Lewis, and Makonnen, Nkrumah considered the written word to be an essential component of the political struggle, and he intended for the daily newspaper to be "the backbone of the party," as it became the most effective means of mobilizing the nation and broadcasting the movement's demands and agenda. ${ }^{133}$

\section{Positive Action:}

In his text The Gold Coast Revolution, Padmore stated that the CPP represented a continuation of "the Manchester Program." ${ }^{34}$ Nowhere was this demonstrated better than in the Nkrumah's call for "Positive Action," which he characterized as the "legitimate and constitutional means by which we can cripple the forces of imperialism in this country." Emphasizing their natural and inalienable right to self-determination, Nkrumah listed among the tactics of Positive action: Legitimate political agitation, newspaper and education campaigns, and "as a last resort, the constitutional application of strikes, boycotts, and non-co-operation based on the principle of absolute nonviolence." ${ }^{135}$ Having derived this tactic from the resolutions of the Manchester 1945 Congress, Nkrumah promoted Positive Action as the party's most effective tactic for asserting their demands. Positive Action was for alarm not just for the elites in the UGCC but also for the chiefs and especially the British colonial administration. He demonstrated the validity of this claim in January 1950 when he called for Positive Action after a series of failed discussions between the CPP and the colonial government for constitutional amendments.

\footnotetext{
${ }^{133}$ Biney. The Political and Social Thought of Kwame Nkrumah. (2011), 43.

${ }^{134}$ Grilli. Nkrumaism and African Nationalism. (2018),51

135 "What I mean by Positive Action Speech." 1949. Kwame Nkrumah Papers, box, 154-31, folder 27.
} 
While the campaign of nation-wide general strikes, boycotts, and noncooperation was short lived, the colonial government declared a state of emergency, Nkrumah and other CPP leaders were swiftly tried and sentenced to prison for promoting an illegal strike, the Accra Evening News was closed and banned. These events caused Nkrumah and the CPP 's popularity to spike, as their incarceration demonstrated that they were willing to sacrifice everything for the movement. Nkrumah spent 14 months of what he called "extreme boredom" in prison. During this incarceration, he wrote instructions for party members on toilet paper, primarily concerning efforts to restart the Accra Evening News and prepare for the approaching general election. Even with his incarceration, Nkrumah received 22,780 votes out of 23,122 in the Accra constituency. ${ }^{136}$ Beyond that, the February 1951 election saw the CPP become the majority party within the Legislative Assembly. Such success at the ballot box resulted in Nkrumah being released from prison two days after the election and being invited to begin his tenure as the Gold Coast' Leader of Government Business. The victory in the 1951 general election represented the first qualitative victory for the people of the Gold Coast, as they now had perhaps the most representative government the nation had ever seen and Nkrumah had successfully brought the less favored sections of the colony (farmers, fishermen, market women, clerks, teachers) into political participation.

In June 1951, Nkrumah embarked on a trip to the United States, where his alma mater, Lincoln University, had awarded him an honorary degree of Doctor of Laws. Addressing the American audience at Lincoln, Nkrumah chose not only to express his gratitude for the honorary degree but also to outline the objectives and principles of the

${ }^{136}$ Biney. The Political and Social Thought of Kwame Nkrumah. (2011.), 44 
CPP . After ceremonially denying being a communist and asserting the necessity of selfgovernment in the Gold Coast, Nkrumah reiterated his Pan-African roots by evoking the recently deceased Marcus Garvey. As Nkrumah exalted his hero, he suggested, "There never was a better period for the 'Back to Africa' movement of Marcus Garvey than today. Let Negro scientists and technicians and teacher flow in ever large numbers to the Gold Coast to help build the new Gold Coast, yea, the new Ghana-a New Africa." ${ }^{137}$ In one of his first international speeches since being elected, this appeal to the African diaspora for assistance in building the Gold Coast demonstrated not only the influence of Garvey on Nkrumah's thinking but also reflected a plan that was already set in motion. En route to Lincoln, Nkrumah stopped in London for two days and found himself once again sitting at George Padmore's kitchen table and consulting with his former mentor on the political landscape both in Britain and Ghana. Padmore had been paying close attention to the political unrest in the Gold Coast and was ready to answer Nkrumah's call for assistance in the next stage of Pan-Africanism.

\section{A Clear Choice For Padmore}

What Nkrumah had been able to do in the Gold Coast in such a short period was no small feat. Few political movements have been as efficient in carrying out their objectives as was Nkrumah in his initial years in the Gold Coast. Upon his arrival, he wrote out a list of objectives to execute as he built up the Gold Coast's nationalist movement and presented them to the leaders of the UGCC. Nkrumah envisioned three phases of the revolution: (1) coordination and consolidation of all the various organization under the UGCC; (2) demonstrations throughout the country to test

\footnotetext{
${ }^{137}$ Ibid., 44
} 
organizational strength through political crises; and (3) convening a Constitutional Assembly of the Gold Coast people to develop a Constitution of Self-Government and Positive Action. Nkrumah, in just 27 months, had executed each of his objectives "down to the comma," and as CLR James observed it was "a revolution of our times." 138 While the Colonial Office in London and the colonial administration in the Gold Coast looked on in confusion, George Padmore looking on from London was thoroughly impressed by what Nkrumah had been able to do, calling it an extension of Manchester and "PanAfricanism in Action." 139

From London Padmore continued his work with the Pan-African Federation, supporting and following the political developments of nationalist movements in Africa and the West Indies. As it concerned Africa, Padmore kept a close eye on Nnamdi Azikiwe's (Zik) Nigeria and Nkrumah's Gold Coast, both of which appeared, in the years following the Manchester Congress, to be primed to commence the campaigns for independence throughout the rest of the continent. By 1951, the political landscapes in Nigeria and the Gold Coast were traveling in opposite directions. While Nkrumah was mobilizing a mass nationalist movement based on presenting a unified Gold Coast, transcending class, ethnic, and religious divides to demonstrate the colony's preparedness for independence, Nigeria was as divided as ever.

Plagued by political affiliations based on regionalism and ethnic sub-nationalism, the Macpherson Constitution of 1951 solidified these divisions by providing a federal system of three regions, each with its regional assembly that elected members to a central House of Representatives. These regional assemblies caused political parties to

\footnotetext{
138 James. “Kwame Nkrumah: Founder of African Emancipation.” (1972), 9-10.

139 Padmore. Pan-Africanism or Communism. (1971)
} 
emphasize cultural and ethnic identities in their organizing, and ultimately emphasis was placed on ethnic sub-nationalism rather than national interests. ${ }^{140}$ Additionally, while the constitution provided for the first general election in Nigeria, the colonial government ensured that the House of Representatives was regionally controlled to preclude encroachment from a mass nationalist movement.

In Nigeria, the British Colonial administration sought to capitalize on regionalism and ethnic divisions to prevent what had taken place in the Gold Coast. With Azikiwe failing to capture support beyond the Igbo areas, and the entire colony afflicted with the cancer of tribalism, Padmore stated "That's why I have concentrated on Nkrumah. For he is the only one who can apply a Marxist analysis to the given tribal situation."141 Only two years later Padmore wrote in a letter to Nkrumah that "Brother Zik and Awolowo have sold Nigeria down the river... These Nigerians are a rotten lot! Tribalism had eaten into their very souls."142 In Padmore's eyes the federalism approach applied in Nigeria, which worked against the formation of an efficient centralized government, stood in direct opposition to his Bolshevik inspired approach to revolution, which emphasized a strong party with a clear program that appealed to a broad constituency that derived its leadership from individuals that could rally the people and effectively articulate their demands with authority and confidence. For this very reason, Padmore threw his support and full commitment behind Nkrumah and the Gold Coast, as the CPP had amassed a nation-wide movement based on colonial solidarity and was on a clear path to

\footnotetext{
140 Toyin Falola and Matthew M. Heaton. A History of Nigeria. (Cambridge: Cambridge University Press, 2008), 153.

${ }^{141}$ Marika Sherwood. "George Padmore and Kwame Nkrumah: A Tentative Outline of Their Relationship." in George Padmore: Pan-African Revolutionary, edited by Fitzroy Baptiste and Rupert Lewis (Kingston: Ian Randle, 2009), 164.

142 George Padmore to Kwame Nkrumah, August 18, 1953, MSGC, Kwame Nkrumah Papers, box 154-41, folder 14.
} 
successfully secure independence through its constitutional reforms through the strong leadership of Nkrumah.

As a result, the 1951 election solidified Padmore's position that it was the Gold Coast, as opposed to Nigeria or any of the West Indies colonies, that would lead the way towards independence. From this point on Padmore would closely advise Nkrumah, the future Prime Minister on the political strategies applied for attaining Self Government in the Gold Coast. Padmore understood that politics, like war, is not a science but an art, that is determined not only by subjective factors, but objective conditions of a given situation. For Nkrumah and the Gold Coast, the objective condition was that ultimately the discretion to exercise and eventually transfer power in the colonies. ${ }^{143}$ This basic fact was at the foundations of Padmore's approach to advising Nkrumah on British politics, which he confessed to having a fascination for.

\section{Padmore as Nkrumah's Agent in London}

In the 1950's Padmore became a regular in attendance for sessions of the British House of Commons, and for members of the British Parliament, a prominent individual to turn to for information on the complex issues arising in the colonies. Furthermore, the CPP 's victory in the Gold Coast prompted Padmore to again offer his network or contacts to Nkrumah, this time not only in the form of trade unions and anti-colonial activists but rather MPs in London, like Fenner Brockway, that was sympathetic to their cause of decolonization and self-government. These MPs, especially in the Labour Party,

\footnotetext{
${ }^{143}$ James. Decolonization from Below. (2014), 122.
} 
would prove vital to Nkrumah in the coming years as he made his case for selfgovernment and independence.

\section{Promoting Positive Action, and Nkrumaism:}

Ever the revolutionary journalist, Padmore understood the significance of metropolitan attitudes and public opinion as it concerned the national psychology of the British race, which he believed were a necessity for gaining self-determination in the colonies. Observing the British response to the violent process of anti-colonialism that manifested in the Mau Mau Rebellion in Kenya, Padmore reiterated the pragmatism of Positive Action as a non-violent and legitimate tactic for gaining self-government. This was predicated on Padmore's observation that the British were "fundamentally a lawabiding people and the minute they have that colonial politicians advocate violence in settling their disputes, they alienate whatever sympathy their British friends may have for their cause." ${ }^{144}$ As a result, Padmore undertook the duty of shaping Nkrumah's image to the international press as a leader of the people, a true revolutionary, and a man that never turned a deaf ear to anyone in need. Thus, as the Mau Mau were being portrayed bloodthirsty savages terrorizing white settlers in Kenya, Padmore prioritized the portrayal of the endeavors of Nkrumah and the CPP in the Gold Coast as a demonstration of the ability of colonial peoples, Africans at that, to constitute 'modern' societies. Understanding the universality of European civilization and cultural values as the central organizing principle of colonialism, Padmore understood that the transfer of power would be found in the ability to organize, and acquire political power through constitutional

\footnotetext{
${ }^{144}$ Ibid., 125.
} 
means, thus dispelling the stereotypes of barbarism and savagery used to justify the colonial system.

With Nkrumah forming his government and independence on the horizon, Padmore now had the political opening he was searching for in Africa. In April 1951 Padmore flew to the Gold Coast for three months to attend the first meeting of the new Legislative Assembly and Nkrumah's installation as Leader of Government Business cover the aftermath of the colony's first general election for international newspapers. Padmore lived with Nkrumah and was immediately at work shaping Nkrumah's government and party structures. In the brief trip, Padmore helped to organize CPP headquarters and the editorial office of the Accra Evening News. At Nkrumah's request, Padmore also organized the newly formed Department of Foreign Affairs, and not only created a study syllabus for its members, but he also drafted an outline of the diplomatic procedure for the Department.

On this trip, Padmore demonstrated that he would be vital to the development of Nkrumah's political philosophy based on socialist principles. He even had plans for a Department of Political Education, which he intended to "prepare the leading cadre along the lines of Socialist outlook."145 During this trip, Padmore toured the country, addressing CPP members reiterating first, that self-government and economic development needed to progress together, and second that "From now on it is the plebian masses, the urban workers, artisans, petty traders, market women, and fishermen, and the clerks, the junior teachers and the vast farming communities in rural areas who are the makers of Gold Coast history." 146 Upon his return to London, Padmore compiled his

\footnotetext{
145 Ibid., 133.

146 Padmore. The Gold Coast Revolution. (1953), 67
} 
notes, interviews, and observations of the Gold Coast into a text entitled The Gold Coast Revolution, which traced the history of nationalism in the Gold Coast from the Asante Confederacy through the victory of the CPP in 1951.

Following this trip Padmore now acted as Nkrumah's official representative in London, "running errands between here and the continent" for Nkrumah, giving updates on debates in the House of Commons and providing clippings of British newspapers and magazines. Additionally, Padmore made use of his journalist background as he staged a campaign for self-government in the Gold Coast, writing articles on CPP and publishing Nkrumah's speeches in the British press. ${ }^{147}$ From his own experience, Padmore understood that the British press would not "publish anything about the Gold Coast or any colony unless there is a riot' and that as long as Nkrumah and the CPP continued "to be respectable statesmen instead of trouble-makers, the English press will have forgotten you." 148 Furthermore, to maintain the relevance of Nkrumah and the Gold Coast and to sway British public opinion, Padmore cast Nkrumah as a charismatic leader that appealed to not only the chiefs and aristocrats but to the working masses as well to advance the interests of all "rich or poor, high or low, white or black."149

\section{Unity, Opposition, and the Dyarchic Partnership}

The period between 1951 and 1954 was a period of apprenticeship governance characterized by cooperation and compromise between Nkrumah and the British colonial administration as they worked toward the inevitable transfer of power. Historian Ama Biney called this era the "Dyarchic Partnership," reflecting the power-sharing between

\footnotetext{
147 Sherwood. "George Padmore and Kwame Nkrumah.” (2009), 166

148 George Padmore to Kwame Nkrumah, December 29, 1951, Nkrumah Papers, box 154-41, folder 3.

149 James. Decolonization from Below. (2014): 135.
} 
Nkrumah and the CPP, and the colonial governor, Sir Charles Arden-Clarke, and the adoption of a seeming accommodationist disposition to procedures of British colonial governance. Accepting the significance of acquiring political power through what the British viewed as legitimate constitutional means, Padmore's pragmatic political strategy was demonstrated in Nkrumah's introduction of the "Tactical Action" strategy to the CPP. Introducing the new strategy to the CPP in February 1951, Nkrumah reiterated "the danger and difficulties" that were ahead of them as they took their place in the Legislative Assembly and stressed the vitality of pressuring the colonial system from both within and without. ${ }^{150}$ Tactical Action would feature a transition from the rhetorical and overt disposition of vehement opposition to British colonial rule, to an embrace of the transitional period of apprenticeship governance under as provisions for independence were made.

While Nkrumah called for more cooperation with the colonial administration as a steppingstone to self-government, Tactical Action also maintained the necessity of the CPP 's unyielding position that the Coussey constitution of 1951 was "bogus and fraudulent." 151 Still Nkrumah's attempt to reassure the radical element of the CPP that they still had a role to play, the party faced factionalism as the 1952 local elections approached. The position of cooperation and compromise adopting by Tactical Action, too many, reflected Nkrumah's acceptance of the current colonial system. Appearing to advocate for a softer approach to criticizing the colonial administration, the CPP appeared to have gone from demanding "Self-Government Now" to merely asking for "Self-Government in the Shortest Possible Time." Nkrumah' attempts to stamp out the

\footnotetext{
${ }^{150}$ Biney. The Political and Social Thought of Kwame Nkrumah. (2011), 49.

${ }^{151}$ Ibid.
} 
emergent factionalism within the CPP by emphasizing the party's commitment to the Leninist concept of "Democratic Centralism" proved ineffective. ${ }^{152}$ Moreover, as a small number of party officers resigned from their positions in late 1951, they cited undemocratic tendencies within the party, and the slowed pace of the CPP 's demands for self-government.

In response to these resignations, Padmore's focus remained on the necessity of unity. For Padmore, the maintenance of unity was essential in the transitional period that the Gold Coast now faced. He maintained that if the CPP were ever destroyed it would be destroyed only from within its ranks. ${ }^{153}$ Urging Nkrumah to exercise firmness with those party members frustrated that things were not moving as rapidly a planned and patience with those who could not grasp the political maneuvers being implemented with Tactical Action. Additionally, Padmore stressed that everything must be done to remove any misunderstanding and factionalism, to facilitate reconciliation and ensure unity within the party. ${ }^{154}$ This resulted in the expulsions of a small number of party members that openly criticized Nkrumah at the CPP conference. These expulsions resulted in the formation of the Ghana Congress Party, with the political objective of maintaining "an effective opposition to the CPP government."155

Aside from the opposition growing from within the CPP, Nkrumah's introduction of a controversial piece of legislation caused a bitter discontent to the Gold Coast's historical social order. The Local Government Ordinance of 1951 and the Gold Coast

\footnotetext{
${ }^{152}$ Democratic Centralism was the CPP's organizing principle, which specified that no individual is to be greater than the party and that individual opinions are to be subordinated to the decisions of the majority. For more see: Charles Boateng. The Political Legacy of Kwame Nkrumah. (Lewiston, NY: Edwin Mellen Press, 2003) 34.

${ }^{153}$ George Padmore to Kwame Nkrumah, January 13, 1952, Nkrumah Papers, box 154-41, folder 14.

${ }^{154}$ Padmore to Nkrumah, January 13,1952, Nkrumah Papers, box 154-41, folder 14.

${ }^{155}$ Biney. The Political and Social Thought of Kwame Nkrumah. (2011), 53.
} 
Marketing Board Ordinance of 1951 called for newly formed democratic local councils to collect revenue from the cocoa revenue in the stool lands. This legislation forced the CPP to confront the paradox of popular democracy and the traditional power of the chieftaincy, which historically considered themselves natural rulers with the only legitimate claim to controlling the wealth derived from cocoa revenue. During the reading of the bills in the Legislative Assembly, Dr. J.B. Danquah, Nkrumah's ideological and political rival since his days in the UGCC, denounced the bill as dangerous to the authority of the chiefs in the Asante region and the Akim Abuakwas state, which produced one-fifth of the Gold Coast's revenue. This bill was the first step in curbing the power of the chieftaincy, as control of the stool lands was now derived from democratically elected local councils that reserved one- third of membership to the local traditional leadership. Nkrumah maintained the position that the government had the right to use cocoa revenue as national property to be redistributed fairly across the nation for economic development.

Conversely, Danquah considered this legislation to be a clear violation of individual and communal rights to the free enjoyment of the property. He further characterized this proposal as "naked and unashamed" communism. ${ }^{156}$ Charges of communism became a common criticism of Nkrumah from the opposition parties that emerged during this period. While CPP rhetoric since 1951 had made regular references to the party's commitment to socialism and plans to eventually "establish a Socialist state," it never expressed how socialism would be realized or implemented in Gold Coast. By October 1953, the British colonial administration found itself on edge after The

${ }^{156}$ Biney. The Political and Social Thought of Kwame Nkrumah. (2011.), 51 
People's Progressive Party (PPP) in British Guiana was declared a community party by the British government for planning general strikes to destabilize the colony's economy. This resulted in the suspension of the constitution of British Guiana and the dismissal of Dr. Cheddi Jagan's democratically elected government. Shortly after this, an assessment of the threat of communism in Gold Coast was requested by the British Colonial Office, as the colonial administration's acquiescence to constitutional reforms had been based on the assumption that there was no communist threat in the Gold Coast.

Since his days as a member of WANS in London, Padmore warned Nkrumah to stay clear of communism, specifically the reach of the influence of the Comintern. With the communist crisis in British Guiana, Dr. Jagan and the PPP's flirting with the World Federation of Trade Unions, what Padmore called a "new Moscow instrument for making trouble," proved the legitimacy of his warnings. ${ }^{157}$ According to Padmore, Dr. Jagan played right into the hands of the Tories, giving them cause to dismiss all dialogue on constitutional reforms and independence. Writing to Ivar Holm in November 1953, Padmore boasted that he warned Nkrumah to stay clear of communism and Russia, and that "thanks to my advise [Nkrumah] has outmaneuvered them[Britain]" with Fabian tactics of gradualism in pursuit of constitutional reform for self-government. ${ }^{158}$ Padmore's claims were confirmed in Governor Arden-Clarke's response to the Colonial Office, maintaining that "Nkrumah and the other Ministers are becoming increasingly, if gradually, aware of the dangers attendant on communist infiltration and of the importance

\footnotetext{
157 George Padmore to Ivar Holm, July 7, 1953, Nkrumah Papers, box 154-41, folder 14.

158 George Padmore to Ivar Holm, November 23, 1953, Nkrumah Papers, box 154-41, folder 14.
} 
of building up confidence in the Gold Coast in the non-communist world. The lesson of British Guiana is being learnt." 159

This response reflects the necessity of Nkrumah and Padmore's strategy of Tactical Action, that sought to cultivate a pragmatic partnership, which Arden-Clarke described as "close, friendly," and "not unfruitful."160 Furthering their political agenda, Nkrumah followed up Arden-Clarke's by not only publicly denouncing communism, but also expelling two prominent trade unionist from the CPP 's ranks, and in 1954, Nkrumah declared that any person found to be an active Communist would be refused employment within the Gold Coast government including posts in the public service, army, police, labor, and education. ${ }^{161}$ These purges and extreme measures, by Nkrumah, were taken out of necessity to save the ongoing movement for self-government in the Gold Coast.

Padmore congratulated Nkrumah for acting quickly to purge from the party those "under communist inspiration [who] are out to stir up tribal, religious and labor troubles on the eve of self-government."162 Subsequently, while Padmore advised Nkrumah to vehemently reject and protect himself and the CPP from the multitude of charges of communist sympathy, he saw the merit in using these rumors as capital to force the hand of the colonial administration. In his text Pan-Africanism or Communism, a text denouncing Soviet Communism as opportunists in its support of Black liberation movements and elevating Pan-Africanism as the most viable political ideology for Black liberation and decolonization, Padmore warned the imperial powers of Britain, France,

\footnotetext{
${ }^{159}$ Biney. The Political and Social Thought of Kwame Nkrumah. (2011), 54.

${ }^{160}$ Ibid., 48.

161 Thomas Howell, A., and Jeffrey P. Rajasooria, eds. Ghana and Nkrumah. (Facts on File, Incorporated, 1972), 19.

${ }^{162}$ Biney. The Political and Social Thought of Kwame Nkrumah. (2011), 55.
} 
and the United States that "to cheat the Africans on the threshold of independence would only prepare the psychological ground for the Russians when they turn their attention to Africa." 163 As an alternative, Padmore offered the option of acquiescing to the demands of Pan-Africanism and colonized peoples of the world by granting self-government.

Tribalism, The National Liberation Movement, and Securing Self-Government By late-1953, for many CPP members, the reality of self-government seemed in reach, as the CPP controlled parliament voted in a constitutional reform that secured an entirely elected parliamentary chamber of 104 members. ${ }^{164}$ This reform presented yet another source of political tension as the proposal for a second chamber for chiefs was swiftly rejected, which disturbed the chieftaincy. While Padmore and the CPP celebrated this as a victory, that the nation was as divided as ever. The approval of 104 members in parliament, resulted in the re-division of the Gold Coast into 104 electoral districts and 66 new constituencies, which for the first time Nkrumah's return to the Gold Coast caused ethnic and regional interests to frame election voting. 1954 saw the emergence of identity-based political parties like the Muslim Association Party (MAP), The Northern People's Party (NPP), and The Togoland Congress. In addition to these new parties, Nkrumah discovered the new preoccupation with local interests spurred an internal revolt within the CPP, which manifested in 81 rebel CPP candidates running against official CPP candidates in the coming election.

Padmore attributed this internal revolt to a lack of party discipline and a growing spirit of opportunism among CPP members that viewed the party as a vehicle for personal

\footnotetext{
${ }^{163}$ Padmore. Pan-Africanism or Communism. (1971), 267.

${ }^{164}$ George Padmore to Ivar Holm, July 7, 1953, Nkrumah Papers, box 154-41, folder 14.
} 
ambitions and a means for money-making. To preserve the party's political standing, Padmore asserted the necessity of taking drastic steps to suppress revolts "which will spread like wildfire throughout the party and undermine it." ${ }^{\prime 165}$ After his appeals to stand down were rejected by these rebel candidates, Nkrumah, with Padmore's backing, expelled all 81 candidates from the party. Ultimately, the general election resulted in the CPP winning 72 of the 104 seats; however, it was clear that there was a considerable amount of oppositional voting expressed in the proliferation of parties based on regional, tribal, and religious identifies. Recognizing that his mass nationalist movement was now facing similar conditions as those that slow progress in Nigeria, Nkrumah immediately made it publicly known that he opposed political parties formed on these bases. While the CPP 's majority rule in the Legislative Assembly was insured, it was clear that tribalism had revealed itself in the Gold Coast, and in September 1954 Nkrumah would be forced to face his most formidable opposition, the National Liberation Movement.

\section{Tribalism and the Opposition:}

To Padmore it was tribalism, not communism, that he perceived as the largest threat to African emancipation and decolonization. Calling it the "present menace," Padmore asserted that tribalism is "exploited by unscrupulous politicians to spread disunity and separatism among the more politically backward sections of people, and undermine the forces working for national integration." ${ }^{166}$ In acknowledging that colonizing Europeans did not create Tribalism, rather they exploited it and still bear the responsibility for keeping it alive, Padmore lamented the "tremendous difficulties of

\footnotetext{
165 George Padmore to Kwame Nkrumah, May 10, 1954, Nkrumah Papers, box 154-41, folder 14.

166 Padmore. Pan-Africanism or Communism. (1971), 349.
} 
rapid transition from a tribal and feudal society to modern nationhood based on parliamentary democracy." ${ }^{\prime 167}$ Nkrumah later demonstrated Padmore's influence in his text, Class Struggle in Africa, in which he distinguishes between "tribe," which existed before colonialism and is the extended clan with the same ethnic language within a territory, and "tribalism" which arose from colonialism and functioned to exploit feudal and tribal survivals to combat the growth of nationalist movements.

Tribalism, Padmore concluded, came down to a "class conflict" between traditionalist chieftaincy and the bourgeoisie educated elites, that formed the colonized autocracy, and the colonial masses of workers and a younger generation of Africans that are injecting their democratic demands into political discourse through detribalized and non-regional political organizing. As a result, Padmore posited Pan-Africanism as the natural ideological alternative and the only force capable of combating the dangers of tribalism, as it advocates for the "formation of democratically-based nation-wide political parties on a non-tribal, non-regional membership." ${ }^{168}$ Furthermore, by Padmore's account and observations, the CPP was the best example of anti-tribalism political organizing for self-government and independence in Africa, while the clearest display of tribalism in the Gold Coast manifested in the formation of the National Liberation Movement.

By the 1950s, the political implications of the CPP nationalist oriented legislation prompted the National Liberation Movement (NLM) to come into existence in the Asante region in September of 1954, months after Kwame Nkrumah and his CPP swept the Gold Coast's elections. The newly formed opposition, which chose to identify itself as a

\footnotetext{
${ }^{167}$ Ibid.

${ }^{168}$ Ibid.
} 
movement rather than a political party, was comprised by many of the young men of Ashanti, small cocoa farmers numbering in the thousands, wealthy cocoa merchants, and the Asante Youth Association, which had recently turned against the CPP . The NLM was created two reasons, the first concerning economics, and the other involving politics. The economic issue arose as cocoa interests were adversely affected in the Asante region by the policies of Nkrumah and the CPP government that came to power in 1951. During the early 1950 s, the price of cocoa steadily rose, though farmers never succeeded in receiving any substantial portion of this as a return. By the 1954 elections, it seemed, through campaign propaganda, that the government had essentially promised better treatment for farmers.

Following the election, to prevent wholesale inflation in the economy, Nkrumah enacted the Cocoa Duty and Development Ordinance, which forced savings and a development treasury for the state's use. Thus, export duties on cocoa were raised, while the price paid to farmers has frozen at 72 shillings a load, even though the world price was sharply increasing. ${ }^{169}$ In addition to this, the extra revenue gained was to be applied to the government for use in the general development of the Gold Coast. In response, many of the farmers in the Asante region objected, claiming that a larger share of the added revenue should be returned to them, instead of being applied to general needs. While the cocoa issue was a catalyst, farmers in the region had long understood that their financial turn on cocoa was meager; and believed that the large contributions of the

\footnotetext{
${ }^{169}$ Florence Mabel Bourret. Ghana, the Road to Independence, 1919-1957. (Stanford, Calf.: Stanford University Press, 1960), 187.
} 
Asante region to the gross national product of Ghana was being unfairly redistributed to other areas. ${ }^{170}$

Reiterating Marx’s arguments about investments, capital, and development, Padmore believed that the cocoa reserve presented a better option for financing social development than borrowing from other nations to gain capital. ${ }^{171}$ For Padmore, tribalism and nationalism were similar constructs as they were both led by the colonial bourgeoisie. Ashanti nationalism for Padmore was no more than a ploy for the colonial African bourgeoisie to position themselves as brokers of power in Ghana. Padmore's position was echoed in Nkrumah's thoughts on Tribalism in his text, Class Struggle in Africa, in which he follows an assessment of the African bourgeoisie, arguing that tribalism is exploited by the bourgeois ruling classes as a tool of power politics, and operated as a useful outlet for the discontent of the masses. ${ }^{172}$ Despite these social divisions, Padmore would not be diverted from his purpose and commitment to statedriven socialism, party loyalty, and mass politics guided Nkrumah, the nation's popular and charismatic leader.

While the cocoa issue was occurring, the political issue that gave way to the NLM came as new electoral districts were being structured and the Asante argued that the region was underrepresented in the new Parliament. By 1954, the Asanteman Council and the Asante Youth Association, who had been in fierce opposition to each other since the 1940s, stood as a united front and demanded special treatment for the region. They argued the Asante region deserved a larger number of seats in parliament, and since the

\footnotetext{
${ }^{170}$ Minion KC Morrison. Ethnicity and Political Integration: The Case Of Asante, Ghana., 148.

${ }^{171}$ James. Decolonization from Below. (2014):155

${ }^{172}$ Kwame Nkrumah. Class Struggle in Africa. (London: Panaf Books, 1970), 59.
} 
overall number of parliamentary seats had increased the Asante members believed the size of their region warranted a robust increase. ${ }^{173}$ After their demands were refused, the NLM was formed with a primary objective of gaining a federalist form of government that would give financial autonomy to the regions. The opposition also demanded legislature that gave the chiefs and more Asante members, who warned of "the creeping dictatorship of the south," more influence in the national government. ${ }^{174}$

In addition to this the NLM called a roundtable conference in Kumasi with the other opposition parties including the Northern People's Party (NPP), the Ghana Congress Party (GCP), the Togoland Congress (TC), and the Muslim Association Party (MAP). At this October 1954 conference, the allied opposition parties called or a federal framework of government and a constitution that would safeguard their regional and economic interests against what they perceived as an encroaching authoritarian CPP . In response to this meeting of the opposition parties, Nkrumah addressed a CPP rally in Accra, describing as yet "another attempt by imperialists and reactionary agents to bring together some chiefs and disgruntled opposition politicians to undermine the popular elected government." ${ }^{175}$ According to historian Ama Biney, the formation of the NLM threw Nkrumah and the CPP government off-balance, just as the Nkrumah led riots of 1948 had thrown the colonial government into a flux. However, what was clear was that the CPP government would not compromise with the NLM regarding cocoa prices, nor were regionalist or tribalist constitutional reforms on the table.

\footnotetext{
${ }^{173}$ Richard Rathbone. Nkrumah \& the Chiefs: The Politics of Chieftaincy in Ghana, 1951-60. (Athens: Ohio State University Press, 2000), 66.

${ }^{174}$ Bourret. Ghana, The Road to Independence, 187.

${ }^{175}$ Biney. The Political and Social Thought of Kwame Nkrumah. (2011), 67
} 
In addition to leading the force of tribalism in the Gold Coast, the NLM's formation presented conflict in the personal circles of Padmore and Nkrumah. Joe Appiah, Padmore's longtime friend from the Gold Coast, had left London and emerged as a leader of the NLM. During their time in London Appiah and Padmore had forged a close friendship, through collaborations in WANS and WASU, and their assistance to Nkrumah, which culminated in Appiah serving as a witness to Padmore's will, and Padmore serving as best man in Appiah's wedding. ${ }^{176}$ Coming from the Asante aristocracy, Appiah inherited a substantial fortune and property upon his return to the Gold Coast in November 1954. After announcing the formation of the NLM in a letter to the editor of the Ashanti Pioneer, Appiah resigned from the CPP . While Appiah maintained that his defection from the CPP was due to Nkrumah's failure to address corruption within the party, Padmore interpreted his resignation as a conscious and deliberate turn to tribalism.

What Padmore viewed as a betrayal by Appiah, did not result in anger or attacks, but rather an increase in Padmore's dedication to self-government in the Gold Coast. Furthermore, Padmore's commitment to presenting positive representations of Nkrumah to combat the smears of the NLM resistance made him a target in a number of the Gold Coast media outlets. Ironically, Padmore devotion to independence in the Gold Coast led to his "outsider status" being constructed and reinforced by the opposition. Padmore's insistence upon unified parties, and a centralized socialist government with Nkrumah as a strong leader, intensified resentment among opposition parties and led to several attempts to discredit him. Some of the insults leveled against Padmore in local newspapers

\footnotetext{
176 James. Decolonization from Below. (2014): 150.
} 
labeled him an 'impecunious and stateless ignoramus' who escaped from the West Indies in a tramp ship," or described him as "completely detribalized and without moral scruples." 177

A series of editorials even argued that Padmore grandfather must have been a traitorous slave that lied on other innocent slaves causing them to lose their lives. ${ }^{178}$ These attacks depict a particular contempt for Padmore as well as descendants of those that left West Africa to be enslaved in the Americas. The coupling of Padmore's lack of tribal identity and an alleged hereditary moral deficiency, suggests a belief that "nonAfricans" like Padmore lacked not only cultural ties but also a value system that formed the core of a person's identity in Africa. Padmore matched the opposition's attacks on his character with his criticisms of tribalism, which he viewed as a disruptive force, led by the colonial bourgeoisie, that hindered unity and distracted national attention away from critical issues of economic and social transformation.

\section{Tribalism and Violence in the Gold Coast:}

Such was the case for the NLM, who Padmore referred to as "cocoa politicians" consisting "of the big chiefs, disgruntled intellectuals like Joe [Appiah] and businessmen" financed by the trading companies to abolish the government's trade monopoly. ${ }^{179}$ Padmore's position was confirmed in October 1954, the NLM took a more serious trajectory, as the Asantehene and the fifty paramount and divisional chiefs gave the movement their approval in a signed petition to the Queen of England. They prayed for a commission of inquiry into the question of a federal government for the Gold Coast.

\footnotetext{
177 Ibid., 152.

${ }^{178}$ Ibid., 153.

${ }^{179}$ George Padmore to Kwame Nkrumah, May 10, 1954, Nkrumah Papers, box 154-41, folder 14.
} 
These claims revolved around the notion that the Asante population was sufficient to warrant additional representation.

Given the democratic nature of Gold Coast politics, it was not unreasonable to demand that the number of seats in government reflects the population percentages. This letter to the Queen posed a great concern to Padmore and Nkrumah, as it presented the image of a Gold Coast that was not unified and therefore not yet fit for independence. Furthermore, Padmore believed that the British would use the NLM to double-cross Nkrumah. He derived these suspicions from a document that he received revealing a plot between the Ashanti opposition and the United Africa Company, in which NLM leaders, Joe Appiah and Kofi Busia received "a million and a half pounds" to stage a revolution against the CPP . ${ }^{180}$ While Padmore had notified Nkrumah of the plot, he swiftly fired the British agent facilitating the plot, as the NLM opposition, with a new motto of "No Federation, No Self-Government," mounted violent resistance to the CPP government in attempts to undermine Nkrumah's self-government aspirations. ${ }^{181}$

Violence erupted in Kumasi, the former capital of the Ashanti Confederation, between NLM and CPP members, in the form of bombings, assaults, and several political murders. This violence continued for years as a result of a disagreement. Historian, Florence Mabel Bourret, notes that the Gold Coast government was extremely slow to recognize and respond to the situation and suggests that there may have been an initial unwillingness to consider the NLM's opposing viewpoints. Nonetheless, by May 1955, Nkrumah's several attempts at a roundtable discussion with the NLM were rebuffed, and

\footnotetext{
${ }^{180}$ Sherwood. "George Padmore and Kwame Nkrumah," (2009), 166.

${ }^{181}$ Jean Marie Allman, The Quills of the Porcupine: Asante Nationalism in An Amergent Ghana. (Madison: University of Wisconsin Press, 1993), 78.
} 
his goodwill gesture of raising the price of cocoa to 80 shillings per load was perceived as a feeble gesture. ${ }^{182}$ It clear at this point that the NLM's position the price of cocoa was being superseded by the demand for a federal government structure.

The violence that took place in the Ashanti region between September 1954 and 1956 had grown so vicious that it caused many Ashanti CPP supporters to relocate to the capital city of Accra, were CPP influence was the strongest. By December 1955 the CPP Information Bureau produced a report on the political tensions in the Ashanti region reporting that NLM fanatics had been removing CPP flags, intimidating and assaulting CPP members, and in special cases, CPP leaders in the northern regions were being tied up and brutally beaten until they resigned from the CPP and joined the NLM. Still, according to some, Nkrumah and the CPP maintained "majority support" in the Ashanti Region, as people who were forced to carry NLM membership cards still maintained their CPP ideas. ${ }^{183}$ Furthermore, by this time some CPP members were "convinced there is a likelihood of civil war breaking out in this district if the vandal and atrocious activities of the NLM remain unchecked immediately." 184

As Padmore looked on the current situation in the Gold Coast, he continued to work as Nkrumah's agent in London. As the violence raged on in the Ashanti region, Padmore felt that the British were trying to use the Ashanti opposition to double-cross Nkrumah and even refused to leave London at times in order "to keep at hand should any sudden storm take place.”185 Additionally, Letters between Padmore and Richard Wright

\footnotetext{
182 Ibid., 96.

${ }^{183}$ Robert H. Neiger to Nkrumah 1/2/55, NLM - Ashanti Opposition 1955-56, GH/PRAAD/RG/17/1/30.

${ }^{184}$ Ahanti Current Affairs (Political Tension) Amanie District, December 1955, NLM - Ashanti Opposition 1955-56, GH/PRAAD/RG/17/1/30.

185 James. Decolonization from Below. (2014), 166.
} 
indicate that he maintained a policy level involvement in Nkrumah's day to day endeavors during this time as he complained of being "saddled" for weeks with "four directors of the Cocoa Marketing Board who have just arrived." 186 Padmore also made arrangements for Gold Coast VIPs visiting London including the Gold Coast Trade Union Council led John Tettagah and Nkrumah's secretary Kofi Baako. In April 1956, Baako was in London to complete plans for independence and to deliver a letter to the Colonial Secretary regarding the 1956 election and the constitution. Padmore "doctored" the letter up before handing it over to the Colonial Secretary and ensure Nkrumah demonstrated that he knew exactly who was behind all the tribalism confusion facing the nation.

\section{Securing Independence:}

In London, Padmore also witnessed the residual effects of the tribalism in the Gold Coast as students in London became divided along political lines between the CPP and the NLM. Padmore believed that it was "a test of Ghana's maturity to settle their internal disputes." Understanding that unity was vital to the British as the prospects for self-government increased, Padmore sought to quell these growing divisions between these students by forming the National Association of Socialist Students (NASSO) as a theoretical discussion group for the Gold Coast students. Under Padmore's direction, Nkrumah appointed law student and former Assistant General Secretary of the CPP, Tawia Adamafio, to establish the organization to unify the students. Unity was vital to everything associated with the Gold Coast, as the violence that had erupted and growing political divisions were perceived to Padmore and the British as a hindrance to

\footnotetext{
${ }^{186}$ Ibid.
} 
independence. As a result, Padmore explicitly stated that naming the group NASSO instead of setting up a London CPP branch was paramount, as it would have exasperated current divisions and prompted the establishment of an NLM branch in London.

The existence of political divisions in the Gold Coast was one thing, however, the potential of having the CPP and NLM elements in London engaged in public debate and disagreement posed a large threat to the image of a progressive and unified colony that was ready for self-government. Back in the Gold Coast, the divisions between the CPP and the opposition elements remained, as the NLM had achieved at least one of their goals. In response to the violence and discord throughout the Gold Coast, the British chose to stall discussions on self-government and independence. Instead the British imposed another election in 1956 for the CPP to demonstrate enough national support to justify the transfer of power.

Nkrumah protested the holding of another election believing that it would only lead to confusion and the essential issue of concern should be in establishing a firm date for independence. He maintained that the will of the people had already been made clear and the constitutionally he could not "another election as a prerequisite to independence," and that "By forcing it upon us the British government will give the impression that they are condoning the anti-constitutional attitude of the NLM and will thereby undermine the fundamental principles of the British parliamentary system." This was the obstacle that Padmore was attempting to avoid in his calls for political unity in the Gold Coast. In response Secretary of State, Lennox-Boyd maintained that a general election was the only answer, for as long as Nkrumah and his "Ministers seem[ed] unable to visit Ashanti I am bound to take notice of this and of its implication that there exists a determined 
opposition in at least one part of the Gold Coast which is not prepared to accept Gold Coast independence under your leadership."187 As such, Lennox-Boyd believed it necessary to test the public opinion and for a "reasonable majority" to manifest as a prerequisite to independence.

Despite the violence and apparent discord throughout the nation, letters of support poured into the CPP 's Accra offices with members pledging themselves to remain "always at the back of [the] CPP ."188 A former CPP wrote to Nkrumah that "I have never been happy since I obtained the NLM card through fear and intimidation as this NLM party has brought gangsterism which hitherto was unknown to this country." 189 Furthermore, while CPP leaders painted the NLM as feudalists, tribalists, and subversives, their economic policies were only slightly to the right of the CPP, as many of the NLM's national executive committee were former CPP members and trade unionists. ${ }^{190}$ Ironically, the CPP had trained, developed and expelled the electoral opposition in its most important election to date. Still, as the 1956 elections approached, Padmore maintained that "To win a voluntary mass basis, the NLM has to produce a more leftist program than the CPP , which like their leadership they cannot do."191 Ultimately, the people proved Padmore right by delivering a victory in the 1956 general election for the CPP winning 71 of 104 seats in the Legislative Assembly, which translated to 398,141 in support of the CPP and 299,116 in support of non-CPP entities.

\footnotetext{
${ }^{187}$ Biney. The Political and Social Thought of Kwame Nkrumah. (2011), 73.

${ }^{188}$ Abena Krah Assistant Leader of the Women's Group, January 9, 1956, NLM - Ashanti Opposition 1955-56, GH/PRAAD/RG/17/1/30.

189 Panin Kofi Manu to Nkrumah March 20, 1956 - NLM - Ashanti Opposition 1955-56, GH/PRAAD/RG/17/1/30.

${ }^{190}$ Manning Marable. African and Caribbean Politics: From Kwame Nkrumah to Maurice Bishop. (London: Verso, 1987), 118.

${ }^{191}$ George Padmore to Kwame Nkrumah, January 19, 1956, Nkrumah Papers, box 154-41, folder 14.
} 
In response to the results, the NLM and the Asante region was left with no other choice than to threaten succession, which threatened the Gold Coast losing its most wealthy region.

The summer of 1956 was a pivotal period in the history of Ghana's independence. The United Nations held a plebiscite in the British controlled Togoland, in which the voters chose to be integrated into the Gold Coast where independence was clearly on the horizon. In the same month, Nkrumah's government issued a white paper with a formal proposal for the Gold Coast's independence. Despite the political tensions continued in the Ashanti Region, the July 1956 general election solidified the CPP as the ruling political party in the nation and the governing body that would lead the nation to independence. As the NLM made its claim as the major opposition to the CPP through its threats of succession and multiple attempts to stall independence, Padmore advised Nkrumah on how to approach the opposition to his party. While Padmore stressed that unity was imperative for the nation to secure self-government, in a rare instance he recommended that Nkrumah seek to cultivate division in the legislative assembly.

Writing to Nkrumah in July 1956, Padmore advised Nkrumah to immediately divide the opposition by recognizing the NPP as the official opposition party in the parliament. ${ }^{192}$ Padmore believed it necessary that Nkrumah's immediate strategy must aim at widening the gaps between the main opposition groups, the NPP and the NLM. Ever the political strategists, Padmore recommended Nkrumah cite a 1954 precedent in which the Speaker, despite Nkrumah's protest and warning, recognized the NPP as the official opposition based on them being the party with the largest number of seats

192 George Padmore to Kwame Nkrumah, July, 24, 1956, Nkrumah Papers, box 154-41, folder 14. 
following the CPP 's position as the majority party. Since the NPP had gained 15 Legislative Assembly seats, to the NLM's 12, Padmore suggested they must be recognized as Nkrumah's official opposition. He believed such a ruling would stir the NLM as the party produced more votes in the election but were granted fewer seats in the Legislative Assembly.

Drawing on the example of the British House of Commons, in which the Labour Party is recognized as the official opposition, along with the Liberals being recognized as a distinct opposition, Padmore noted that only the official opposition leader enjoyed the rights, privileges, and salary of the position. He believed that S. D. Dombo, leader of the NPP, regardless of any agreement he may have had with Kofi Busia, leader of the NLM, would never sacrifice the official salary of the position. As a result, Padmore, in a rare instance, instructed Nkrumah to "Arouse their tribal jealousies," stating that "This is one occasion when you can exploit tribalism to your advantage." ${ }^{\prime 193}$ In particular, he advised Nkrumah to cultivate a situation in which the NPP having ran fewer candidates and won more seats than the NLM, were perceived to be trying to gain what they could not at the polls through the back door of the Parliamentary apparatus. Furthermore, causing discord and division amongst the opposition parties, for Padmore, would prevent them from uniting against Nkrumah and the CPP and potential attempts to halt discussion on selfgovernment once again.

Nkrumah capitalized on the moment by introducing a motion calling for independence to the Legislative Assembly, which was swiftly passed, despite the NLM opposition walking out of the session. Having won 12 of the 21 seats of the legislative

${ }^{193}$ George Padmore to Kwame Nkrumah, July, 24, 1956, Nkrumah Papers, box 154-41, folder 14. 
assembly for the Ashanti region, along with the NPP winning 15 of the 26 seats in the Northern region, the NLM attempted to argue the legitimacy of a federation system. The opposition party even sent a delegation to London to meet with Secretary of State Alan Lennox-Boyd to argue for constitutional safeguards with succession as the alternative; however, Lennox-Boyd instructed the NLM to operate within the democratic boundaries of the Legislative Assembly. To gain the upper hand on the opposition, Nkrumah invited Secretary Lennox-Boyd, to the Gold Coast to hear the NLM constitutional proposals. The January 1957 discussions between Lennox-Boyd, the NLM, and the CPP resulted in an amended constitution that maintained the four regions, created a Regional Assembly, and established a House of Chiefs. Additionally, the Asantehene was recognized as the head of the Asante region; and safeguards were imposed to prevent threats of carving up the Asante region by the central government. ${ }^{194}$ While the CPP stood firm on most of its positions, mainly the issue of cocoa, the NLM saw victory in compromise and were ready to approach independence as a unified Gold Coast. Now with a constitutional agreement that seemed to satisfy all parties involved, it was apparent that Nkrumah had secured the declaration of independence from the British and preparations for independence on March 6, 1957, were scheduled.

\section{Independence and Beyond}

The celebrations for the official end of British colonial rule in the Gold Coast commenced at midnight on March 6, 1957, the symbolic date of African independence. ${ }^{195}$ As a crowd of a hundred thousand Ghanaians assembled in the capital, Nkrumah

\footnotetext{
${ }^{194}$ Allman. The Quills of the Porcupine, (1993), 178.

${ }^{195}$ Grilli. Nkrumaism and African Nationalism. (2018), 64.
} 
declared: "At long last, the battle has ended! And thus, Ghana, your beloved country is free forever!" Fully aware of Ghana's significance to the rest of the modern world, the Ghanaian Prime Minister asserted that Africa was ready to demonstrate that "the Black man is capable of managing his affairs." Delivering his speech wearing a traditional Northern Ghanaian batakari, Nkrumah declared "We are going to demonstrate to the world, to the other nations, that we are prepared to lay our foundation - our African personality." This term "African Personality" had been coined nearly a century earlier by West Indian Pan-Africanist, Edward Wilmot Blyden, who was a pioneer in promoting repatriation to the African continent and a large proponent of Blacks in the African diaspora identifying with Africa in their thinking. ${ }^{196}$ Additionally, after touring West Africa in the nineteenth century, Blyden acknowledged the sophistication of African civilizations and culture and advocated for its necessity and applicability in Black liberation movements.

Along these same lines, Nkrumah emphasized the Pan-African significance of Ghana's independence as he famously emphasized to thousands of Ghanaians that: "OUR INDEPENDENCE IS MEANINGLESS UNLESS IT IS LINKED UP WITH THE TOTAL LIBERATION OF AFRICA.” The independence celebrations were truly a PanAfrican affair as dignitaries and officials of African descent from across the globe were in attendance to witness the birth of Africa's first independent nation. Ensuring the significance of making the independence celebrations a Pan-African and international affair, Padmore advised Nkrumah in the months before inviting Eric Williams and all of

\footnotetext{
196 James Conyers. "Edward Wilmot Blyden and the African Personality: A Discourse on African Cultural Identity." In Racial Structure and Radical Politics in the African Diaspora, edited by G.A. Persons, 151168. (Routledge: New York, 2017)
} 
the "big shot" African Americans and West Indians. ${ }^{197}$ Among the African Americans in attendance were civil rights leaders Ralph Bunche, Martin Luther King Jr., and Adam Clayton Powell Jr. Writing in January 1957, Padmore implored Nkrumah to send Independence celebration invitations especially to the West Indian politicians who were meeting in Jamaica to discuss prospects for a federation to distract them from their tribalist tendencies and to inspire unity. ${ }^{198}$ Several prominent leaders from the West Indies such as future Prime Ministers of Guyana, Cheddi Jagan, and Forbes Burnham, from Jamaica Andrew Salkey and the nation's future Prime Minister Norman Manley, and Nkrumah's close friends C.L.R. James, T. Ras Makonnen, and Padmore. ${ }^{199}$

Further reflecting the Pan-African context in which Ghana's independence took place, Nkrumah paused in his speech stating: "Here I wish I could quote Marcus Garvey. Once upon a time, he said, that he looked through the whole world to see if he could find a government of Black people. He looked around, he did not find one, and he said he was going to create one. Marcus Garvey did not succeed. But here today the work of Rosseau, the work of Marcus Garvey, the work of Aggrey, the work of CaselyHayford, the work of our illustrious men who have gone before us had come to reality at the present moment." ${ }^{200}$ This moment was truly the crystallization of dream come true, as freedom from nearly a century of colonialism domination had been gained, and Nkrumah placed Ghana, a small nation of six million people at the center stage of a new era of African history and that of the African Diaspora. Subsequently, while CLR

\footnotetext{
197 Sherwood. "George Padmore and Kwame Nkrumah,” (2009), 168.

198 George Padmore to Kwame Nkrumah, January 7, 1957, Nkrumah Papers, box 154-41, folder 14.

199 Daryl Zizwe Poe. Kwame Nkrumah's Contribution to Pan-African Agency: An Afrocentric Analysis. (New York: Routledge, 2004), 108.

${ }^{200}$ Biney. The Political and Social Thought of Kwame Nkrumah. (2011), 78.
} 
James would christen Nkrumah, the "Father of African Emancipation," in Ghana the name "Osagyefo," meaning "Redeemer" in Akan, had been bestowed upon him following this ceremony.

Even the Queen of England recognized the gravity of Ghana's independence, noting in here official address that "the hopes of many, especially in Africa, hang on your endeavors. It is my earnest and confident belief that my people in Ghana will go forward in freedom and justice." ${ }^{201}$ After independence, Ghana remained a member of the British Commonwealth and engaged Westminster procedure in its ceremonies. Following the reading of the Queen's message, he sent a humble address of thanks to the former Imperial power. Extending a hand of goodwill and friendship, as opposed to adopting a disposition of bitterness and resentment, Padmore's pragmatism again influenced Nkrumah's approach to British politics. Maintaining the Westminster Parliamentary system, Nkrumah opened Ghana's first Parliamentary session stating: "If, on the other hand, we fail, if we show ourselves disunited, inefficient or corrupt, we shall have gravely harmed all those millions in Africa who put their trust in us." ${ }^{.202}$ Upon hearing Nkrumah's mention of corruption the opposition gave an outburst of "Hear, hears." The irony in this instance is found in the fact that it was the opposition that did everything in their power to halt and delay independence and as recent as two weeks before the independence celebrations, Baffour Akoto, a founder of the NLM informed the chief regional officer, A.C. Russell, that there would be no independence celebrations in the Ashanti region. ${ }^{203}$ Still, in Parliament, there was genuine applause from both the CPP

\footnotetext{
${ }^{201}$ Gavin Fuller. The Telegraph Book of Readers' Letters from the Great War. (London: Aurum Press Limited, 2014)

202 Ibid.

${ }^{203}$ Biney. The Political and Social Thought of Kwame Nkrumah. (2011), 77.
} 
government and the opposition, who compromise on the Constitution after the 1956 elections demonstrated the political maturity of the newly formed nation.

In his Independence celebration speech Nkrumah reiterated that while the nation had won the battle against colonialism, their success rested on them rededicating themselves to building the nation and aiding in the liberation of the rest of the African continent. Padmore too understood that there was much work to be done and that time could not be wasted on celebrating. Writing to Richard Wright in January 1957, Padmore debated whether or not he would attend the independence celebrations stating: "I really cannot afford the money just to see spades dance. ${ }^{" 204} \mathrm{He}$ was eventually convinced by Nkrumah to attend, who refused to accept any excuse whatsoever. Although Padmore agreed to attend, the purpose of his two-month trip to Ghana was not to celebrate but rather to reaffirm the role of each citizen, in taking ownership and personal investment, in the next phase of Ghana's revolution. Rather than dancing in the streets, Padmore was primarily concerned with praising the Ghanaian masses, whose devotion and selfsacrifice had made the birth of Ghana possible. In doing so, Padmore emphasized that hard work and self-discipline would be vital to the building of the nation.

Observing Padmore's disposition, Ralph Bunche noted that at the independence celebration he "was not looking very convincing in the Kente cloth role he was affecting." ${ }^{205}$ Remembering the state ball, CLR James recalled that while Padmore loved to wear African clothes, his mood was somber, and he was very quiet. As dignitaries, government officials, and the Ghanaian elites danced into the night, James noticed tears in Padmore's eyes. Padmore then lamented that "the people who are dancing in here, are

\footnotetext{
${ }^{204}$ Sherwood. "George Padmore and Kwame Nkrumah," (2009), 168.

${ }^{205}$ Ibid.
} 
the ones who opposed independence. Outside are all the market women, and others, who funded the movement, who fought for the movement, who did all the work of the movement, but they are not in here dancing." This Padmore exclaimed was "no good at all."206

Always in Padmore's immediate concerns were the interests the Ghanaian working masses, and according to James, this was not lost on them as he recalls riding with Nkrumah, during the celebrations, through crowds of people shouting "Hello, Padmore!” "How are you, Mr. Padmore," “Good Evening, Mr. Padmore.” According to James, Padmore was not riding with them but "If a black stranger was in the Prime Minister's car on a night like this then it was, of course, Mr. Padmore. I had the heart nor the courage to disappoint them. So, I accepted the greetings and smiled and shook hands on behalf of George."207 Padmore understood that independence was merely the first step and that while the struggle for self-government was important, the present struggle would now be waged between the barefoot masses and the Ghanaian aristocracy and middle class.

It was not lost on Padmore that one of the reasons he chose to work with Nkrumah in Ghana was because it posed the best chance for staging a Pan-African Socialist revolution in Africa. In the weeks following independence Padmore stayed in Ghana attending meetings of the Central Committee where he examined the economic and political situation facing the new nation. Despite having no official position in the government, Padmore spent a good amount of time meeting with and teaching the

\footnotetext{
206 James. Decolonization from Below. (2014), 168.

${ }^{207}$ C. L. R. James. Notes on the Life of George Padmore, 48, C. L. R. (Cyril Lionel Robert) James Papers; July 30, 2019; box 5, folder 21; Rare Book and Manuscript Library, Columbia University Library.
} 
principles of socialism to the CPP youth. Beyond his recent idea to establish NASSO, Padmore's particular interest in the youth dated back to 1955 when he wrote to Nkrumah on the necessity of inspiring the youth stating that "We need to give them the tools to carry on the struggle after we have gone. Marx was right. Ideas are more dangerous than H-bombs which they can't use after all.".208 In a message to the CPP Padmore declared that establishing socialism in Ghana would "create a new type of human society on the African Continent which will be an object lesson to the work and an inspiration to our brothers who are still struggling to free themselves from foreign rule and alien domination." 209

During this time, Padmore also traveled to Sierra Leone to support a youth movement that hoped to influence the nation's upcoming elections. Subsequently, Sierra Leonean politician, Hugh Smythe, who was in Ghana the independence celebrations, informed a reporter for the NAACP's Crisis magazine, that Padmore was "the silent hero of Ghana and a figure venerated and respected throughout black Africa. ${ }^{, 210}$ For Padmore, Ghana's independence, while important, was a prelude to African socialism, and his dealings in Ghana in the weeks following independence were a testament to this. Historian, Leslie James, notes that at the foundation of the Pan-African Socialist revolution Padmore envisioned taking place in Ghana, was a dual progression of both national and international interests. For Padmore, real socialism was essential "a philosophy of internationalism" and one could not "be truly socialist at home and at the same time adopt an attitude of racial chauvinism and contempt towards other peoples or

\footnotetext{
${ }^{208}$ George Padmore to Kwame Nkrumah, August 5, 1955, Nkrumah Papers, box 154-41, folder 14.

${ }^{209}$ James. Decolonization from Below. (2014), 168.

${ }^{210}$ James R. Hooker. Black Revolutionary; George Padmore's Path From Communism To Pan-Africanism. (New York: Praeger, 1967), 130.
} 
act as an imperialist aboard."211 As such, the application of socialism to the Black nationalism of Pan-Africanism was a natural progression for Padmore and remained at the underpinnings of his dealings with Nkrumah and Ghana.

Planning to leave Ghana in mid-May, Padmore advised Nkrumah that it was necessary to impose a temporary transition period of "benevolent dictatorship" if Ghana were to get started on the road to civilization. Padmore believed that there was "so much to do at all levels, and so much mess to be cleaned up that no other way but the strong government can even essay the task." ${ }^{212}$ Leslie James attributes this advice to Padmore's early political training in the Soviet Union and the model of the Bolshevik Revolution, which emphasized the role of the state in efficiently developing socialism. This was not lost on Nkrumah, who understood as well as Padmore that the British had left the nation in a mess and there was much that still needed to be overcome.

According to Padmore, in April 1957 Nkrumah begged him to stay and help him implement his plans for the nation. Padmore recalled Nkrumah stating "George if you leave us now all that you \& I have worked for will fail after having kicked these British bastards out." ${ }^{213}$ He could not decline such an appeal and immediately set about developing plans with Nkrumah for rural electronification, setting up rural water deposits, and road building to connect the farms to major motor roads. On the international front, Padmore and Nkrumah hosted a delegation of "Young Turks" from Félix Houphouet-Boigny's Rassemblement Démocratique Africain (RDA) who traveled to Accra and expressed that Ghana's independence had set the surrounding territories

\footnotetext{
${ }^{211}$ James. Decolonization from Below. (2014): 168-169

${ }^{212}$ Sherwood. "George Padmore and Kwame Nkrumah," (2009), 168.

${ }^{213}$ Hooker., 169
} 
aflame and had the French worried stiff. In these initial moments, Nkrumah, with "his hands [now] free, set out systematically to initiate and carry through the policies of the Manchester Conference on the most expansive scale."214 To do so, Padmore, the architect of the modern Pan-African movement, was needed not as an intermediary in London but in a permanent capacity as a government official in Ghana.

\section{Padmore the Advisor on African Affairs}

With self-government secured, Nkrumah was primed to place his Pan-Africanism into practice through the Ghanaian government. As a result, on November 12, 1956, Nkrumah announce Padmore as the Prime Minister's Advisor on African Affairs. Padmore did have his reservations about moving to Ghana and becoming an expatriate advisor to Nkrumah. ${ }^{215}$ He understood all too well that the persisting menace in Ghanaian politics was that of tribalism, which he had become all too familiar with in recent years. For Padmore tribalism held back the industrialization of the nation and presented a tremendous difficulty for the rapid transition from a tribal and feudal society to modern nationhood based on parliamentary democracy. As a result, Padmore placed his hope in the newly emancipated younger generation of Africans, most of whom, according to him possessed a detribalized outlook, in comparison to the Tory-mined expatriates and the autocratic chiefs, resented the passing of power to the common people officials. $^{216}$

Furthermore, Padmore entered Ghana conceiving of Tribalism as integral to a "class conflict" that only sought to deter his and Nkrumah's plans to liberate the African

\footnotetext{
${ }^{214}$ James. Notes on the Life of George Padmore, 57, C. L. R. James Papers, box 5, folder 21.

215 Sherwood. "George Padmore and Kwame Nkrumah," (2009), 170.

${ }^{216}$ Ibid.
} 
continent. In a calculated move against tribalism, Nkrumah's government passed the Avoidance of Discrimination Act (ADA) in December 1957, which banned the formation of political parties based on tribal or religious allegiances. While the ADA was meant to neutralize the opposition, it catalyzed unifying the opposition parties of the Ewe, Ashanti, and Ga ethnic groups in the formation of the United Party, as the primary opposition to the Convention People's Party.

Returning to London to gather his belongings for this three-year contract position with the Ghanaian government, Padmore presented his plans to his Barbados born physician, Dr. Cecil Belfield Clarke, who encouraged him to take up the post in Ghana, believing the warm climate might alleviate his constant, if intermediate ill health, which he would struggle with for the entirety of his time in Ghana. He was also met with a farewell gathering of Africans and West Indians. The group of comrades and allies presented with a leather briefcase engraved with a map of the Black Atlantic, and Dr. Kwame Sanaa-Poku Jantuah, the High Commissioner for Ghana in London, said: "George has been given that post, not as a reward for past services but because he was the best man for the job." ${ }^{217}$ Addressing those in attendance, Padmore stated that he was merely "going to Ghana to give my advice when it is asked for."" 18 Padmore's mission was to transform Ghana into a Mecca of Pan-African for African freedom fighters, with the eventual goal of establishing the United States of Africa. There was truly no one more qualified for the work Padmore was poised to undertake in Ghana.

While Padmore's qualifications were apparent to the Pan-African community and Nkrumah, these sentiments were not shared by everyone in Ghana and would elevate the

\footnotetext{
${ }^{217}$ Ibid., 169

218 James. Notes on the Life of George Padmore, 58, C. L. R. James Papers, box 5, folder 21.
} 
concern over Africanization of the civil service to a major concern in Parliament. Several of the Ghanaians serving in Parliament came from prominent families, were educated in London, and saw themselves as distinguished men of British tradition, with the only legitimate claim to administering government in Ghana. Furthermore, when Padmore entered the nation in the same month as the introduction of the ADA, it only exacerbated those factions of the Ghanaian government that were already in a scramble for power in the newly independent nation. Ultimately, while Padmore's work in Nkrumah's administration would prove to be stimulating and productive, he was still treated as an outsider in Ghana. The fact that Padmore was not a Ghanaian and the charges that he was still a communist, caused elements in the Ghanaian government to disapprove of his newly created position, especially since he operated separate from the civil service, was unelected and shared a close friendship with Nkrumah.

As a result, Padmore's actions in this new position placed under him a microscope of public critique for the entirety of his tenure in Ghana and, from day one his appointment was protested by the opposition in Parliament for a number as reasons. The first concerned the necessity of the position all together as United Party representative, Mumuni Bawumia, questioned "whether the prime Minister is not himself an African acquainted with the nature and problems of Africans. He ought to know the African and his problem and he does not therefore need the advice of another on African affairs." 219 Another argument against Padmore's appointment came from A.L. Adu, the Britishtrained permanent Secretary for Foreign Affairs, who claimed: "Padmore was not competent to advise Nkrumah on African affairs because he had not lived in Africa."220

\footnotetext{
${ }^{219}$ Ghana, Parliamentary Debates, March 11, 1958, 133, GH/PRAAD/ADM/14/7/5.

${ }^{220}$ Sherwood. "George Padmore and Kwame Nkrumah," (2009), 172
} 
Adu's argument disregarded the nature of Padmore's previous work and well-established position as arguably the most famous Pan-African organizer and black Marxist on the planet. If anyone was qualified to oversee Ghana's Pan-African foreign policy, it was undoubtedly the man with nearly four decades of experience working in anti-colonial activist circles, with a network spanning multiple continents and transcending multiple language barriers.

Interpretations of Africanization:

The third objection to Padmore's appointment engaged the issue of "Africanization of the Civil Service," which had been a recurrent topic of discussion in the Legislative Assembly and Parliamentary Debates of the 1950s and 60s. The issue of African representation in civil service positions persisted throughout the early twentieth century. Africanization of the civil service called for top posts in the government, many of which were being filled with white expatriates, to be replaced with qualified Africans. ${ }^{221}$ In 1947, 19 of 92 senior posts in the civil service were held by Africans, and as decolonization took place the British established a Select committee on Africanization to make recommendations for facilitating Africanization. ${ }^{222}$ In 1951, A.L. Adu was appointed Commissioner for Africanization. Although Adu and Nkrumah disagreed on the necessity of Padmore's role in Ghana, he and Padmore agreed on the issue of Africanization. Padmore was a proponent of Africanization since 1951 when Nkrumah became Leader of Government Business; however, his concern was not merely with

${ }^{221}$ Gold Coast, Legislative Assembly Debates, March 9-18, 1953, 1059, GH/PRAAD/ADM/14/2/77. ${ }^{222}$ Richard Rathbone. "The Transfer of Power and Colonial Civil Servants In Ghana." (The Journal of Imperial and Commonwealth History 28, no. 2, 2000), 71. 
representation but rather with the "trojan horse advisors" that served the interests of the British Empire instead of the people of the Gold Coast. ${ }^{223}$

Writing the Nkrumah in January 1952, Padmore foresaw the issue of importing repatriates becoming "a popular issue to mobilise opposition around, especially among African civil servants who naturally feel that they are being cheated." 224 As such he advised that under no condition should Nkrumah "accept the new salary scales and allowances for repatriates," as the Gold Coast was already paying the highest salaries and increases would end in Bankruptcy for the country. In favor of removing British officials from the government, Padmore maintained that: "If the whites don't want to be satisfied with equal pay for equal work then give their jobs to blacks. They will soon learn. Nothing educates like RESPONSIBILITY; so stand firm." Despite this, Nkrumah chose to trust Governor Arden-Clarke's plan for Africanization, which by independence in 1957 had yet to produce a comprehensive African civil service.

While the expatriates serving in the government included individuals of both African and European descent, the comments made about West Indians government officials, like Padmore, displayed a particular resentment and fundamental opposition to Nkrumah's Pan-African vision for the nation. According to historian Kwadwo AfariGyan: "Some people objected on the ground that there were already several West Indians in senior positions in the administration and the judiciary."225 Furthermore, the power and influence that Padmore wielded caused resentment, particularly because of his title, the Advisor on African Affairs, on the grounds that "a West Indian could hardly have

\footnotetext{
${ }^{223}$ George Padmore to Kwame Nkrumah, November 15, 1950, Nkrumah Papers, box 154-41, folder 13. ${ }^{224}$ George Padmore to Kwame Nkrumah, January 25, 1951, Nkrumah Papers, box 154-41, folder 13. ${ }^{225}$ Sherwood. "George Padmore and Kwame Nkrumah," (2009), 173.
} 
anything to teach them about Africa." ${ }^{226}$ Mr. Bawumia of the United Party went as far as to declare to Parliament that "It is very disgraceful for an all-African government to employ the services of a foreigner to come and advise them on African affairs. At least if there was the need for an advisor, they should have appointed an African."227 W.A. Wiafe of the CPP countered Bawumia's argument stating that "When we talk of Africans, some people here say that West Indians are not Africans. I do not want to dilate much on this point, but I only want to point out that the person appointed as Adviser on African Affairs is an African. There is no doubt about that." ${ }^{, 228}$

These debates in Parliament regarding Padmore's Africanness as a qualification for serving as Nkrumah's Advisor on African Affairs, reveal more than a mere prejudice to outsiders working in the Ghanaian government. They problematize commonly accepted notions of racial essentialism that rest at the very foundations of conceptions of not only diaspora but Pan-Africanism as well. The very idea of Pan-Africanism relies on the assumption of racial essentialism that is predicated on the shared histories, ancestry, oppression, and social conditions of people of African descent. The notion of the shared conditions associated with Blackness is integral to Pan-Africanism, as it is the only definitely attribute that binds people of African descent to each other. Regardless of how they identify themselves, the racial identity and social standing conferred upon Blacks will always transcend national borders, class, language, and political ideology. However, the situation in Ghana, regarding Padmore's Africanness, presents a unique opportunity

\footnotetext{
226 James. Decolonization from Below. (2014), 171.

${ }^{227}$ Ghana, Parliamentary Debates, March 11, 1958, 133, GH/PRAAD/ADM/14/7/5

${ }^{228}$ Ghana, Parliamentary Debates, March 11, 1958, 142, GH/PRAAD/ADM/14/7/5
} 
for exploring the limitations of Pan-Africanism, as it confronts the concept of racial identity in the context of the post-war age of decolonization itself.

In the context of African nationalism and the rise of national consciousness in Africa, the transnational and migratory nature of West Indian culture comes into direct conflict with the fundamental elements that inform African identities such as ethnicity, kinship, or language. In Ghana as Padmore sought to place his Pan-Africanism into practice through the Office of the Advisor on African Affairs, Ghanaians in the Parliament found it difficult to identify the "tribeless" Padmore with their own African identity. To many of them, regardless of the work he had done for Africa and Ghana in particular, Padmore would always remain an outsider. Such a position invokes Brent Hayes Edward's assertion of the necessity of décalage in analyses of diaspora. ${ }^{229}$ While notions of diaspora tend to focus primarily on racial essentialism and stress the similarities of the Black experience that transcend national borders, it must be understood that as these Black transoceanic interactions take place, décalage or notions of "gaps" and "differences" in not only language but in culture and identity that must be translated in both articulations and disarticulations of the diaspora are just as significant. Thus, for several Ghanaians, Padmore's outsider status in addition to the privileged and insulated position Nkrumah created for him within the government would remain an issue of contention throughout his tenure in Ghana.

Although Padmore had always intended to respectfully offer his advice to Nkrumah and Ghanaian government when he was asked for, he later admitted that he "we had a hard struggle, meeting with hostility from some of the very people we were trying

${ }^{229}$ Edwards. The Practice of Diaspora. (2009) 
to serve." 230 While Padmore's disputes from the opposition are understandable, the resentment that he received from some CPP members is unexpected. According to historian, Kofi Buenor Hadjor, there was "considerable opposition even within the CPP " to Padmore's appointment. ${ }^{231} \mathrm{He}$ was continually criticized and resented by some CPP leaders for his role in NASSO, in which he served as a mentor and advisor to the group holding weekly study sessions, sometimes attended by Nkrumah. In these sessions, Padmore tried to instill in the youth proper socialist ideals and attitudes to counter the "phoney socialism" that he observed in some of the CPP members. ${ }^{232}$

This was Padmore's way of providing a political education to the future of their movement and militarizing the youth against "ignorance," in order to keep them engaged in issues of national importance. As early as January 1952, Padmore impressed upon Nkrumah the significance of the youth, suggesting that everything must be done to remove misunderstandings within the party, especially when it concerned relationships between the old guard and the youth. Padmore implored Nkrumah to avoid the mistake of past revolutions in their tendencies to "devour [their] children." ${ }^{233}$ Writing to Nkrumah in 1955, Padmore admitted that his seminal text, Pan-Africanism or Communism, was written for the youth in order "to give them the tools to carry on the struggle after we have gone." 234 Regardless of his good intentions and the extensive work done behind the scenes, Nkrumah eventually abandoned his initial plans of appointing Padmore to a cabinet post, seeking to minimize dissent from within and outside of the CPP by making

\footnotetext{
230 James. Notes on the Life of George Padmore, 58, C. L. R. James Papers, box 5, folder 21.

${ }^{231}$ Kofi Buenor Hadjor. Nkrumah and Ghana. (Trenton, NJ: Africa World Press, 2003), 92.

${ }^{232}$ Kwadwo Afari-Gyan. "Kwame Nkrumah, George Padmore and WEB Du Bois." Research Review 7, no. 1 (1991): 1-10, quoted in Sherwood. "George Padmore and Kwame Nkrumah,” (2009), 173.

233 George Padmore to Kwame Nkrumah, January 13,1952., Nkrumah Papers, box 154-41, folder 14.

${ }^{234}$ George Padmore to Kwame Nkrumah, August 5,1955., Nkrumah Papers, box 154-41, folder 14.
} 
Padmore his personal advisor. Historian Marika Sherwood suggests that these observations of CPP resentment may call into question the accuracy of James' recollection events at the Independence celebrations. More importantly it is curious as to whether CPP members were opposed to Padmore the individual, or that they simply wanted Ghanaians directing the government instead of foreigner, regardless of the fact that arguably no foreigner wholeheartedly supported the CPP more than Padmore.

Initially Nkrumah intended for Padmore to serve as Advisor on African Affairs working out of the Ministry of Defence and External Affairs (MDEA); however, both men realized the foreign service, many of whom were British expatriates leftover from the Colonial administration or British trained Africans, could not be trusted to carry out their Pan-African program. For some time, Nkrumah had been aware of an "attitude of dual allegiance - one loyalty to our government and the other to the Colonial Office." In executing this plan, Nkrumah first took control of the MDEA, which in line with Padmore's previous advice on the necessity of Nkrumah taking external affairs into his own hands and "guiding the country in its orientation as it moves into the sphere of international relations." ${ }^{235}$ Since it was clear that the MDEA the civil servants in the external service and foreign affairs "would hardly enable us to project the African personality" in their relations with other nations, Nkrumah decided to create an institution, separate from the MDEA, in order to do so.

As a result, Nkrumah directed Padmore to build his own office modeled on the anti-colonial organizations he had spearheaded throughout his entire career from his days in Russia as Secretary of the International Trade Union Committee of Negro Workers

\footnotetext{
${ }^{235}$ George Padmore to Kwame Nkrumah, July 24, 1956, Nkrumah Papers, box 154-41, folder 14.
} 
(ITUCNW), and London as a founder of the Pan-African Federation (PAF). This new office was appropriately named: The Office of the Adviser to the Prime Minister on African Affairs. Drawing on his work with the Chairman of the International African Service Bureau (IASB), this new office would also operate as an investigative body for recovering information and contacts, a propaganda forum for spreading Nkrumah's PanAfrican ideology, and a medium for exchanging news on anti-colonial movements throughout Africa and highlighting the views of African leaders. This office was the culmination of decades of Padmore's activist organizing, providing him the resources and free-range to apply his expertise to cultivating African unity by providing political and financial support to African liberation movements in furtherance of Pan-Africanism and African emancipation. Furthermore, since "officially" the office would supplement rather duplicate the work of the Ministry of External Affairs, Padmore was positioned to operate as "a de facto Ghanaian 'shadow' Minister of External Affairs" as he traveled the African continent to export, what Matteo Grilli calls, "Nkrumah's Pan-African policy."236 Still, several foreign services and government officials opposed Padmore's independent office, citing discomfort over a non-Ghanaian representing the independent nation in negotiations with foreign states. Also, the role of Nkrumah's distrust of his civil servicemen cannot be ignored in our understandings of their opposition to Padmore's appointment; nonetheless, the unorthodox system of governing the Nkrumah was implementing set the stage for confrontations within the CPP government that would last for several years. In what Nkrumah viewed as an attempt to avoid potential conflict with other civil servants, Padmore was also given the freedom and authority to select his

${ }^{236}$ Grilli. Nkrumaism and African Nationalism. (2018), 79. 
staff, which forced the issue into a debate among government officials. In parliament, Nkrumah was criticized for the "Trojan Horse" tactics being used in the employment of the Special Adviser on African Affairs. United Party representative M.K. Apaloo was outspoken on the subject stating:

I know that the holder of the present position is an old friend of the Prime Minister and he belongs to the Pan Africa Group. But what I want to say here is that when the original amount for engaging this man was asked for, the government did not come forward with an estimate... Now, after this gentleman has arrived and assumed duty, he is putting forward proposals for the engagement of staff, and believe me, Sir, if the qualifications he wants for his immediate subordinate are to be the ones they would insist on, then no single African in this country, except perhaps the Minister of Finance or the Leader of the Opposition, would become his assistants. In other words, if he insists upon having people who have traveled widely across Africa as his subordinates - well, you see, nobody would in fact have that qualification, and therefore we shall have to go back the West Indies perhaps, to get his immediate juniors to come and advise us on African affairs. ${ }^{237}$

Mr. Apaloo's concerns were shared by several government officials who also believed the West Indian ex-Comintern official, Padmore, exercised too much power because of his direct line to Nkrumah and his requirement that his office's staff meet his qualifications. It also did not help that Nkrumah was slow to explicitly state the role that the new office would play, and exactly why the MDEA had been cut off from interacting with African liberation movements. However, while the unease pertaining to the lack of transparency in the estimated costs of Padmore's office were warranted, the concern regarding his hiring practices and standards were unfounded. Padmore was primarily concerned with recruiting reliable men that shared his ideologies and possessed extensive experience working in anti-colonial struggles. The fears of an entirely West Indian staffed office were put to rest when Padmore chose a Ghanaian, James Markham, and T. Ras Makonnen from Guyana as his top assistants in his office.

${ }^{237}$ Ghana, Parliamentary Debates, March 11, 1958, 138-139, GH/PRAAD/ADM/14/7/5. 
Both men easily met Padmore's qualifications. Markham, a man of Ewe descent, had strong ties to the anti-colonial struggle in Ghana and had proven himself a trustworthy supporter of Nkrumah dating back to his time as editor of the Accra Evening News, being imprison with Nkrumah in 1949, and helping to organize Nkrumah's election campaign in 1951. ${ }^{238}$ Also, Markham maintained correspondence with Padmore during his time working for the Anti-Colonial Bureau of the Asian Socialist Conference in Rangoon and attending the Bandung Conference in $1955 .{ }^{239}$ Like Padmore, Markham was a seasoned journalist and a leading figure in NASSO, which made him useful in carrying out the Office's propaganda campaigns. Additionally, Makonnen was an old friend of Padmore and Nkrumah's from their days in the Pan-African movement in London. Along with being more closely aligned with Padmore than anyone in the nation from an ideological standpoint, Makonnen's extensive experience in newspaper editing and his proficiency in dealing with managing finances made him a perfect candidate for Padmore's Office. As, a result the trio of Padmore, Markham, and Makonnen ran the Office, with a staff comprised entirely of Ghanaians. ${ }^{240}$

In spite of the protest and cool attitude of the foreign service, Padmore was once again in his element, this time with "more money, more power, and more freedom of action to put his ideas into practice." ${ }^{241}$ For the last three decades, Padmore had grown accustomed to either working on his own or with a skeleton crew of trusted individuals within executive committees of the activist organizations. According to CLR James, Padmore admitted that there were two things in the world that he could not take, the first

\footnotetext{
${ }^{238}$ Padmore. The Gold Coast Revolution. (1953), 81.

${ }^{239}$ Grilli. Nkrumaism and African Nationalism. (2018), 83.

${ }^{240}$ Hooker. Black Revolutionary. (1967), 133.

${ }^{241}$ Ibid., 109-140.
} 
being race prejudice and the other bureaucracy. ${ }^{242}$ The frustrations of bureaucracy were also shared by Nkrumah, who was known to cut through normal procedure to accomplish his objectives in Ghana. ${ }^{243}$ This was reflected in the structuring of Padmore's Office. Free of intricate infrastructure and meant to be flexible and act swiftly when political action was needed, the size of Padmore's office, seven staff members in a "fair-sized single-story bungalow," embodied how Ghana's first Pan-African institution was intended to operate. Padmore expressed his expectations in a letter to his staff stating:

I feel that we are devoting too much attention to what I consider petty routine matters which can be dealt with more efficiently... all directives, observations and recommendations addressed to me must be stated as laconically as the English language permits... I frankly have no time for "essay reading." 244

The humor in Padmore's message is apparent; however, it merely shielded his frustration with the formal bureaucratic structures of the Ghanaian government. In the same note, he lamented that Ghana's traditional bureaucracy weighed upon his office like the Alps and called for his office to streamline "the work of this office as much as possible without unduly offending the "the sacred cow", bureaucracy."245

While his Office operated independent of the MAEA, there was constant overlap, as his office was focused on practicing Pan-Africanism through transnational relations on the continent and the MDEA was concerned with international relations. The result was a constant state of poor communication between the two offices. For instance, in February 1959 when the US Embassy called upon Padmore to discuss Ghana's position

\footnotetext{
${ }^{242}$ James, "Notes on the life of Padmore", Nation, 8 January 1960, quoted in Schwarz, "George Padmore," 147.

${ }^{243}$ Makonnen. Pan-Africanism From Within. (1973), 154.

${ }^{244}$ George Padmore to the Administrative Officer, 30 July 1958, GH/PRAAD/RG/17//579.

${ }^{245}$ George Padmore to the Administrative Officer, 30 July 1958, GH/PRAAD/RG/17/1/79.
} 
on the Cameroons, the memorandum on the issue had been sent to the MDEA. ${ }^{246}$ The foreign service "refused to let Padmore use their cable service and denied him access to their file. "247 Recalling that the MDEA "tended to keep things very in their own hands," Padmore constantly insisted upon the being afforded the proper respect but also found it necessary to project authority in order to ensure that information was received in time for his office to act efficiently. Although Padmore struggled to adapt to the day to day politics of Ghanaian bureaucracy, he would now turn his eyes away from the local tribalized politics of Ghana. With independence secured and Nkrumah's resources at his disposal, Padmore switched his focus to the rest of the continent and in turning Ghana into a model nation that exuded the principles of Pan-Africanism not only in rhetoric but in action.

The Office of the Advisor on African Affairs and Exporting Nkrumaism With his office established, Padmore, The Advisor to the Prime Minister on African Affairs got to work immediately on using Ghana and Nkrumah's fame and political standing to spurring independence throughout the rest of the continent. In January 1958 Padmore was tasked with establishing a United Nations Regional Economic Commission for Africa, as well as overseeing Ghana's bid to have the commission based in Accra. Joining the small number of independent nations in Africa, Ghana was now in competition not only for the commission but also for political influence on the continent with Egypt, Sudan, and Ethiopia. Working with Mordechai Kidron, the Deputy Head of Israel's permanent delegation to the UN, Padmore contended that Ghana would be the best choice for the location of the commission since: Ghana was

\footnotetext{
246 James. Decolonization from Below. (2014), 172.

${ }^{247}$ Hooker. Black Revolutionary. (1967), 135.
} 
the latest African independent state to be admitted as a member of the United Nations; it was more advantageously located than the other three countries, and the Ghana government was ready to provide all necessary facilities for the accommodation of the office. $^{248}$

While Ghana sought to establish its position of influence on the African continent to the UN, Padmore and Nkrumah sought the do the same throughout African by planning the Conference of Independent African States. They discussed calling a PanAfrican Conference back in 1954, but Padmore suggested postponing such a meeting until independence was secured. Plans for the conference subsequently began in early 1958 and Padmore led a delegation mission to the seven independent African nations at the time - Egypt (UAR), Sudan, Libya, Tunisia, Morocco, Ethiopia, and Liberia. On these missions, Padmore along with the Minister of External Affairs met with ambassadors and nation heads to discuss the conference's agenda, procedure, and administrative arrangements.

The arrangements were largely in Padmore's hands as he was now entrusted by Nkrumah to "work out a program of non-violent "Positive Action" and a "Tactical Action" [program] on a continental scale."249 With Padmore authoring Nkrumah's Inaugural Address, the themes of African unity, cooperation, and the African Personality were centralized. Coordinating their foreign policy, the nations agreed on the significance of the "sovereignty of the state," and pledged their support of African independence and self-determination. While no monumental decisions were made at the

\footnotetext{
248 George Padmore to Chapman, 14 January 1958; Cable, Mordechai Kidron to Padmore, undated, GH/PRAAD/RG/17/1/79.

${ }^{249}$ Sherwood. "George Padmore and Kwame Nkrumah,” (2009), 174.
} 
April 1958 conference, the nations' voiced their commitment to educational and cultural exchanges, coordinated economic planning, agreement to reconvene every two years, and the repeated use of the term "African Personality" demonstrated the success of the meeting.

In the summer of 1958, Padmore was constantly on the move. He and Nkrumah embarked on a "goodwill mission" to the seven participating nations, to further strengthen ties and discuss the plans for a United Nations African Group. On this trip Nkrumah publicly expressed his gratitude to Padmore for his "loyal support, devotion to duty and pleasant companionship" calling him "the life of our party." ${ }^{250}$ In July of that year, Padmore represented Ghana as an unofficial observer at the congress of the African Regroupment Party (PRA) in Dahomey, where the demands of the French-speaking states were voiced. He noted that the "the women delegated were the most important factor in stimulating the drive for full independence... I was actually frightened by those women." ${ }^{251}$ With the Algerians in open war with the French, and Ghana energizing independence movements in Ivory Coast, the drive for independence in the French colonies came to center stage in September 1958 with the French Constitutional Referendum and the "Guinea Question."

In October 1958, Sekou Toure led Guinea to independence, voting to no in the Constitutional Referendum and the French leaving the nation in economic ruin. Padmore saw this as an opportunity to launching a project of political unity and suggested to Nkrumah that he offer a loan of $£ 10$ million to save the Guinea economy. As a result of this offer, Toure could not avoid Nkrumah's proposal of unification, and after accepting,

\footnotetext{
${ }^{250}$ Ibid., 175.
}

${ }^{251}$ Ibid. 
the Ghana-Guinea Union was announced in November 1958. The Governor of Sierra Leone summed the moment up perfectly stating that "Guinea's need had been Nkrumah's opportunity of advancing Pan African ideas." 252 The Union was intended to demonstrate to budding independence movements the path towards a united Africa. For both Padmore and Nkrumah, the unity of Africa always rested on Pan-Africanism manifesting in the formation of a United States of Africa, but the two diverged on the idea of regionalism maintained opposing views on what that unity should look like.

\section{United States of Africa or Pan-Africa:}

The establishing of a United States of Africa and the idea of uniting the continent under a single flag was always at the foundations of both Padmore and Nkrumah's political agendas. However, by 1958 Nkrumah was in favor of immediately pursuing a United States of Africa, while Padmore embraced the pragmatism of establishing selfgoverning regional federations to be later united with the entire continent. ${ }^{253}$ In a way, Padmore foresaw the conditions that would create the Casablanca and Monrovia Blocs in the 1960s, as African nations became divided on what African unity would look like in a liberated Africa. Furthermore, while Nkrumah's Padmore authored opening speech at the All African People's Conference stated that the Ghana-Guinea Union constituted the nucleus of a United West Africa to later become a United States of Africa, Nkrumah's vision began to prevail as, by May 1959 the official declaration of the union referred to a "Union of Independent African States" that were opened to all independent African

\footnotetext{
${ }^{252}$ British Governor of Sierra Leone to the Secretary of State for the Colonies and the Governor-General of Nigeria, 24, November 1958, TNA, FO 141/13649, quoted in Grilli. Nkrumaism and African Nationalism. (2018), 91.

${ }^{253}$ Padmore. Pan-Africanism or Communism. (1971), 356.
} 
States or Federations adhering to the principles on which the Union is based. ${ }^{254}$ In July 1959, Padmore was in Liberia with Nkrumah to discuss a unification between Ghana, Guinea, and Liberia to be called "The Community of Independent African States." Unfortunately, the three heads of state agreed to leave in place the colonial boundaries stemming from the Berlin Conference of 1884, which left in place many of the invented traditions and national identities bred by the colonial system. While the union never materialized and appeared to be shortsighted, having no agenda for implementing many of its resolutions, Padmore and Nkrumah appeared to be diverging in their political outlooks.

Still, the two agreed on the primary goal of Padmore's office, which was to support anti-colonial movements in Africa to create a united front of African nationalist parties and eventually a continental government. In order to achieve this Padmore endeavored to turn Accra into a haven for African Nationalists and chief meeting site for anti-colonial politics. Making use of Padmore's extensive political contacts from his days in Moscow and London, Padmore organized the All African People's Conference, which was held in December of 1958. What set this conference apart from the CIAS was that it was a gathering of over two hundred delegates from thirty-six nongovernmental political parties, movements, trade unions, cooperative associations, and youth and women's organizations. ${ }^{255}$ As the most significant Pan-African gathering since the Manchester 1945 Congress, Nkrumah believed this conference marked a beginning of a new course and chose to use the term "All-African" in the name of the conference as opposed to "Pan-African," as Padmore had suggested. While the two disagreed over the

\footnotetext{
254 Adi. Pan-Africanism: A History. (2018), 148.

255 Biney. The Political and Social Thought of Kwame Nkrumah. (2011), 137.
} 
name, Padmore's influence on the AAPC was also demonstrated in the use of the symbol of a "Black man rising out of the map of Africa, rending as under his chains," on the publicity for the conference, which was lifted directly from the Padmore edited Negro Worker newspaper from his days running International Trade Union Committee of Negro Workers (ITUCNW). ${ }^{256}$

The conference organizers invited members from 62 nationalist parties, delegates from fraternal countries or organizations, and observers from across the globe. Among the attendees were future Prime Minister of Congo, Patrice Lumumba, Alfred Hutchison, and Franz Fanon as a delegate for Algeria. ${ }^{257}$ In addition to the official list of invitees, the conference attracted several uninvited freedom fighters who flocked to Ghana after hearing about the conference. Many of them arriving in Ghana without documents and requesting Padmore's Office to vouch for them. ${ }^{258}$ At the conference, Nkrumah capitalized on the opportunity to promote his ideas on African liberation, and Ghana's recent achievements since gaining independence to entice African revolutionaries and anti-colonial movements to align themselves with Ghana.

Presenting the CPP as a model nationalist party, Nkrumah promoted his Padmore inspired methods for attaining independence, particularly the non-violent strategy of Positive Action. The conference's resolutions reiterated the commitment to the highest standards of life through freedom and independence; the creation of unity and community between independent African states; and the economic and social reconstruction of

\footnotetext{
256 Sherwood. "George Padmore and Kwame Nkrumah,” (2009), 175.

257 Grilli. Nkrumaism and African Nationalism. (2018), 104; and James. Decolonization from Below. (2014), 178.

${ }^{258}$ Makonnen. Pan-Africanism From Within. (1973), 215.
} 
Africa. ${ }^{259}$ While Fanon was an avid supporter of armed struggle based on the conditions in Algeria, a compromise was reached in the AAPC's resolutions which endorsed nonviolence and civil disobedience as well as the right to retaliate against violence where such retaliation becomes necessary. Ultimately, the AAPC established Ghana as the nation willing to take the lead in the for African liberation and the base of Pan-African activity on the continent.

By 1959 Padmore was second only to Nkrumah when it came to Ghana's foreign relations and it was in these 9 months that his large influence in Ghana Pan-African policies was placed on display. Padmore traveled throughout several nations in 1959 and according to a British Foreign Office report, the Ministers of External Affair "played second fiddle to George Padmore when it came to talking business." ${ }^{260}$ Padmore and Nkrumah also decided to form the African Affairs Committee, which was a council of high ranking CPP members, advisors, and non-Ghanaian African nationalists to assist Padmore in carrying out his duties efficiently and catering to the needs of freedom fighters and political refugees that flocked to Ghana. ${ }^{261}$ Central to this was the propaganda being produced by Padmore's Office, which used print media and international radio broadcasts to spread Pan-Africanism in Ghana and the continent.

Padmore's expertise from his decades of international journalism was put to use as his office was tasked with producing publications of the AAPC and IAS conferences, and providing Ghanaian newspapers and booklets to political parties that closely aligned

259 "People's Conference Plans, Permanent Body." Africa Special Report, December 1958, 4, quoted in H. Adom, "The Role of Ghana in African Liberation and Unity, 1957-1977" (PhD Thesis, Temple University, $1911), 84$.

${ }^{260}$ Report on Mr Ebeneezer Ako Adjei, 1959, TNA, FO 371/138163, quoted in Grilli. Nkrumaism and African Nationalism. (2018), 112.

${ }^{261}$ Grilli. Nkrumaism and African Nationalism. (2018), 112. 
with Ghana and the CPP . Furthermore, Radio Ghana was established to spread Nkrumah's messages throughout the continent. Also, as Africa revolutionaries flocked to Ghana, they made use of Radio Ghana to broadcast their programs, concerns, and messages internationally. Padmore also made it a point to broadcast Nkrumah's messages in French and Portuguese to for francophone and lusophone nationalists in neighboring nations to be reached.

Padmore's Office also supported the African liberation movement beyond providing radical literature and radio broadcasts from Ghana. Through his office, Padmore was able to finance political parties and movements in other nations. The Office also provided funding for travel to international gatherings, propaganda, and even in some cases arms when violence was deemed necessary. While the partnerships with Liberia and Guinea were fruitful, Padmore's Office ensured Ghana's influence on the rest of the continent through his political contacts. His Office established early collaborations with Hastings Banda's Nyasaland African Congress, Kenneth Kaunda's United National Independence Party, both of whom developed their parties based on the model of the CPP . Following the AAPC, Patrice Lumumba returned to Congo more radicalized having abandoned his pro-Belgian politics and conveying "rhetoric [that] echoed that of his Ghanaian mentor," which signified the close relationship Nkrumah would develop as Congo gained independence in the coming years. ${ }^{262}$

Padmore's Office's propaganda drove Ghana's influence to East Africa, as Julius Nyerere's Tanganyika Action National Union adopted the CPP slogan of "Forward Ever, Backward Never" and appropriated propaganda from the Accra Evening News for his

262 Paul Nugent. Africa Since Independence. (Macmillan International Higher Education, 2012), 54, quoted by Grilli. Nkrumaism and African Nationalism. (2018), 127. 
speeches. ${ }^{263}$ Padmore's influence on the CPP from the early 1950s also manifested in Uganda, the Uganda National Congress adopted the CPP 's slogan of "Self-Government Now!" and patterned their constitution on the CPP 's aims of eradicating tribal barriers and unity under a central African government. Also, because of his long-time friendship with Jomo Kenyatta from their London days, Padmore's Office established close ties with Kenya’s Tom Mboya and his People's Convention Party.

In addition to providing a model for independence movements across the continent, Padmore's Office also provided political support by infusing new radicalized CPP members into the Foreign Service and directing them to raise questions concerning colonialism and African independence at international gathers, especially at the United Nations. ${ }^{264}$ Thus when an African political party or movement was unable to represent itself in an international conference or the UN, its political statements and requests were conveyed by Ghanaians supplied with directives and messages from Padmore's Office. The success and far-reaching influence of Ghana's Pan-African Policy as administered by Padmore's Office were clear as Ghana became the leading force for African liberation and unity.

\section{The Personality Cult of Nkrumahism:}

Part of this success was due to the emergence of the personality cult known as Nkrumahism. Merging the notions of Pan-Africanism and Socialism, Nkrumaism was set forth as by the Accra Evening News as Ghana's national ideology. Nkrumaism essentially became the Ghanaian brand of Socialism, meaning it did not represent the

\footnotetext{
263 Ibid., 128.

${ }^{264}$ Ibid., 129.
} 
special interest of individual groups, but rather the interests of people and the reconstruction of society. It was promoted "as a social idea that maintains the belief that politically the salvation of Africa was in the effective political union with a continental federal government" (i.e. a United States of Africa). ${ }^{265}$ Nkrumaism was heralded as a "symbol of hope for oppressed Africans," and promoted the rediscovery of " the African-psyche' and the attainment of effective African political unity to prevent the Balkanization of Africa."266 Since his London days, Padmore knew that Nkrumah's vanity was something that required his constant attention; however, he believed in the necessity of Nkrumahism as a way of operationalizing Nkrumah's fame as a tool for advancing Pan-African Socialism. As a result, Padmore maintained that "Destiny has placed an unshrinkable duty on Kwame Nkrumah, not only to inspire the redemption of Africa but most importantly, to provide a distinct African state pattern for the emerging nations of our peoples."267

This idea of the necessity of a charismatic strong leader that exuded intelligence, wisdom, and populism, according to Leslie James can be traced back to Padmore's political training and upbringing in the West Indies where men like H. Sylvester Williams, Hubert Harrison, and Marcus Garvey were venerated for expressing some of the earliest iterations of Pan-Africanism and socialism. Furthermore, Nkrumahism served as an ideology for gaining national support and inspiring loyalist to leader and party, which Padmore believed were fundamental to the success of Ghana. It was also fundamental to propaganda campaigns aimed at presenting Nkrumah to the rest of the

\footnotetext{
265 "Nkrumahism, a socialist philosophy." Accra Evening News, March 18, 1961, 11.

266 "Nkrumahism, Symbol of Hope For Oppressed Africans." Accra Evening News, July 1, 1960, 17.

267 James. Decolonization from Below. (2014), 176.
} 
continent as a champion of African liberation and unity that was primed to lead Africa into the modern age.

\section{Padmore's Death and Legacy}

By August 1959, Padmore's Office reached its apex and Ghana's Pan-African policy was spreading across the African continent; however, due to cirrhosis of the liver, Padmore's health had deteriorated so much that he could no longer hide his condition, and Nkrumah granted him leave to undergo a medical examination. Arriving in London in September to consult his physician, Padmore took some days for himself and drafted letters reiterating his commitment to African unity in a letter to Sekou Toure assuring him that he would see through the Ghana-Guinea Union. Later in that month, Padmore was admitted to University College Hospital with fluid in his abdomen and a hemorrhage that place him in a coma from which he never awoke. ${ }^{268}$ While many believed Padmore had been assassinated by imperialist agents, there was never any evidence to support the claim. While Padmore stated that he wished to be cremated and his ashes buried in Trinidad in his mother's grave, the final burial ground is in Ghana. Leslie James notes the significance of this as there is no monument of Padmore in Trinidad, no institutions bearing his name, and no evidence of his existence.

In Ghana, Padmore was celebrated as a national hero and son of Ghana. Despite their disagreements, upon hearing the news of his death Nkrumah stated that Padmore "was one of the greatest fights against colonialism of our modern times... One day, the whole of Africa will surely be free and united and when the final tale is told the

\footnotetext{
${ }^{268}$ James. Notes on the Life of George Padmore, 60 , C. L. R. James Papers, box 5, folder 21.; and James. Decolonization from Below. (2014), 183.
} 
significance of George Padmore's work will be revealed."269 Speaking at Padmore's burial, Nkrumah remembered that from the time they met fifteen years prior they "thought along the same lines and talked the same language. There existed between us that rare affinity for which one searches for so long but seldom finds in another human being... that indescribable relationship that exists between two brothers."270

Shortly thereafter, Nkrumah declared September 23 George Padmore Memorial Day, and on this day each year until his removal from power flooded the Ghanaian press with special issues dedicated to his friend and mentor's memory and contributions to the nation's independence and that of several other African nations. According to John Phillips, "it has been said that the late George Padmore had been the moving spirit in suggesting and organizing the meetings and in stimulating his friend to speak so clearly, so often and so passionately about Pan-Africanism. Further, it is thought by these and other circles that much of the Prime Minister's interest and emphasis upon the African Personality and the African Community owe their origin to Padmore's influence."271

Others maintained that Padmore's influence on Nkrumah led him down a misguided path believing that Padmore was "out of touch with the new generation of African nationalists... [and] that if Nkrumah himself had taken the trouble to ascertain the thinking of the other African leaders on the subject of Pan-Africanism, rather than relying on Padmore's interpretation of what the shape of Pan-Africanism should be, Nkrumah might have more stature that he has today."272 Critics would agree with this assessment

\footnotetext{
269 “OSAGYEFO'S TRIBUTE TO GEORGE PADMORE.” Accra Evening News, September 23, 1960, 7.

${ }^{270}$ Hooker. Black Revolutionary. (1967), 139-140.

${ }^{271}$ John Phillips, Kwame Nkrumah and the Future of Africa, 1960, 82, quoted in Sherwood. "George Padmore and Kwame Nkrumah," (2009), 182.

272 Hooker. Black Revolutionary. (1967), 137.
} 
citing Padmore misguiding Nkrumah by supporting his implausible plans for a single continental state. What became clear following Padmore's death was that Nkrumah appeared to be free of the checks and restraints that Padmore brought along with his counsel. Nkrumah had parted with Padmore in the end, particularly on the issue of Padmore's views of communism. Whereas Padmore eschewed collaboration with communists, Nkrumah desired to forge stronger ties with the east. With Padmore's death, the direction and emphasis of Nkrumah's approach to governance shifted as his non-aligned position faded as his relationships with Russia and China became more apparent, and the shrew democratic Padmorean politics of the 1950s became increasingly authoritarian.

In the end, Padmore's three years working in Ghana was the period when the ideas, planning, networking, and political strategy of the three decades converged. He left Ghana and Nkrumah with qualified and well-trained staff to continue the work of carrying out Nkrumah's Pan-African Policy; Ghana had become the center of PanAfrican activity on the African continent and the rest of the world; Nkrumah was primed to sever its ties to the British commonwealth, and Ghana was poised to implement a socialist economic development program. Ultimately, Padmore's death was timely as his life's work had culminated in Ghana and his influence set the stage for 1960, the "year of Africa," in which seventeen African nations gained independence thus ushering in a new phase of African history. 


\section{W. ARTHUR LEWIS, PAN-AFRICAN ECONOMICS, AND DEVELOPMENT IN GHANA}

During his 1979 Nobel Prize speech, W. Arthur Lewis recalled: "I had no idea in 1933 what economics was, I did well in the subject from the start." ${ }^{273}$ Enrolling at London School of Economics in 1935, Lewis quickly found himself intent on answering questions as to why some countries were rich and others poor. Lewis was a success upon arrival in London, winning the admiration of his professors, one of whom described him as "My best student, serious and hardworking and remarkably intelligent." ${ }^{274}$ In his first year, Lewis won the Director's Prize for the best undergraduate essay, showcasing a maturity quite unusual in a first-year student. After graduating in 1937 with a B.A. in commerce and first-class honors, Lewis intended to return to work in the West Indies; however, the Colonial Office denied his application to work as a civil servant in Trinidad because he was not of European parentage. In spite of multiple rejections because of his race, one of Lewis' mentor's at LSE recognized his gifts for economic analysis and recommended that he be admitted to the Ph.D. program, noting that he was "the most brilliant of all graduates whose work I have seen."275

Lewis' brilliance and expertise in development economics were not lost to the Pan-African movement, as he went on to serve as Kwame Nkrumah's chief economic advisor as he secured self-governance in the Gold Coast and in the immediate years following independence. This chapter provides an examination of the contributions of St.

\footnotetext{
${ }^{273}$ Sir Arthur Lewis, "The Sveriges Riksbank Prize in Economic Sciences in Memory of Alfred Nobel 1979," NobelPrize.org, accessed July 21, 2020, https://www.nobelprize.org/prizes/economicsciences/1979/lewis/biographical/.

${ }^{274}$ Robert L. Tignor. W. Arthur Lewis and the Birth of Development Economics. (Princeton: Princeton University Press, 2006), 17.

${ }^{275}$ Ibid., 17.
} 
Lucian economist Sir W. Arthur Lewis to nation-building process in Ghana. While nation-building in Ghana during this time was primarily concerned with creating a base for Pan-African liberation for the African continent and raising the standards of living for the nation's citizens, economics was vital to both of these objectives. Through an assessment of Lewis' Pan-African activism and pioneering scholarship in Development Economics in Britain, his contributions to stimulating economic development and industrialization in Ghana, as well as the causes of his deteriorating relationship with Nkrumah, this chapter argues that Lewis was fundamental to Nkrumah's nation-building process in the realm of economics.

\section{An Imperial Education for Decolonization}

The generation of African nationalists that ushered in independence in the $1950 \mathrm{~s}$ and 1960s, had known each other as students in European universities in the 1930s and 1940s. Those African colonial subjects that attended university in London quickly came into contact with a new Black intelligentsia from the West Indies that prioritized taking advantage of rigid and "murderously competitive" education system of the British Empire. In the West Indies, education and the embrace of bourgeois Victorian cultural notions of refinement were linked to social mobility. As a result, the minds of young aspiring scholars like William Arthur Lewis, from St. Lucia, were intensely cultivated in English history, European history, Greek history, Latin, French, and English literature. The son of two school teachers and the fourth of five sons, Lewis was raised in a disciplined and hardworking household that produced a psychiatrist, a civil servant, and a lawyer. His parents passed on their beliefs in the virtues of western culture and English liberalism, which for them fostered humanism and nonracialism. Equipped with this 
belief in rationality, democracy, a deep faith in human beings to rise above racial and religious division, Lewis won a scholarship to study at the London School of Economics (LSE).

Shortly after enrolling in the Ph.D. program at LSE, Lewis' professors made a historic decision by inviting Lewis to join the faculty as a temporary one-year assistant in the economics department. Such an appointment had never been offered before, and his appointment was approved on the condition that he would lecture and takes classes, but he would "not see students individually but only in groups."276 While the appointment committee was unanimous, it recognized that the appointment of a colored man may be open to some criticism. Ultimately, the committee's fears were unfounded, as Lewis was a success as a lecturer, and after his first year, advanced to the rank of assistant lecturer along with his contract being extended an additional four years.

While Lewis initially lectured in the field of transportation, he soon began to teach the principles of economics, economic history, industrial economics (the subject of his dissertation), and lecture on the interwar economy in Europe and North America. Recognized as one of the school's best teachers, Lewis' courses on issues of development attracted students of color from Africa, Asia, and Latin America, which prompted him to offer the department's first course on colonial economics. Setting Lewis' courses apart from others offered in the economic department was that instead of focusing exclusively on British and European economics, Lewis' new courses dealt with the economic particularities of colonial territories. As a result, in these lectures lay the seeds for the

${ }^{276}$ Ibid., 20. 
field of Development Economics, which Lewis would pioneer and direct the discourse on in the late 1940s.

\section{Pragmatism and Pan-Africanism}

Although Lewis established a reputation as a dynamic lecturer at the London School of Economics, his entrance into the Economics Department's faculty coincided with an influx of West Indians and Africans into London that reignited the Pan-African movement. While Lewis' longtime friend and future president of Trinidad, Eric Williams, charted a similar path as an academic at Oxford University, his other West Indian contemporaries, George Padmore, CLR James, and Ras Makonnen became outspoken figures on the significance of Pan-Africanism to anti-colonialism, African Emancipation, and Black political organizing in London. Although he was a selfproclaimed socialist, Lewis did not share the reverence of Marx, the Soviet Union, and trade unionism that many in the Pan-African movement possessed. Still, Lewis shared the same Pan-African sentiments as Padmore, James, and Makonnen, and eagerly joined the International Friends of Ethiopia following Mussolini's invasion of Ethiopia in 1935. Lewis continued to lend his own advice on economic issues in the colonies when the organization renamed itself the International African Service Bureau; however, he never shared the strident radicalism of Padmore and Makonnen. ${ }^{277}$ Instead, Lewis opted for a partisan approach to politics that placed gradual and immediate political gains over the passionate populism that drove the activism of the age.

At the time there was no shortage of Black political organizations in London, and Lewis found companionship in the predominantly West Indian led League of Coloured

\footnotetext{
${ }^{277}$ Matera. Black London. (2015), 82.
} 
Peoples (LCP). In addition to the sociability provided by the League sponsored dinners and dances, Lewis found the organization's moderate approach to its calls for an end to racial discrimination and colonial reform appealing. In the mid-1930s Lewis became a leading figure in the LCP when he became the Publicity Secretary and Editor of the organization's journal, entitled The Keys. ${ }^{278}$ While the LCP membership catered to the West Indian community in London, Lewis used his position as editor of The Keys, to advocate for colonial reforms and strengthen Pan-African alliances amongst people of African descent in Britain. Lewis understood the significance of people of African descent participating in the academic and public discourse surrounding colonialism and sought to highlight Black voices with The Keys. ${ }^{279}$

Under Lewis, The Keys was also deployed to attack the foundations of anti-black racism and European imperialism, which he believed were derived from an unrestrained and fundamentally immoral pursuit of economic gain. In an early issue of The Keys, Lewis argued that racial prejudice was "the result of a deliberate policy, executed for sound economic reasons. Colour prejudice is the active expression of the theory of racial superiority and the foundation and modern excuse for imperialism." ${ }^{280}$ For Lewis, Europe imperialism existed solely to acquire the cheap raw goods and labor to ensure the high living standards of modern Europe; however, he maintained that the barbarous means through which this was achieved (i.e. forced labor, taxed labor, and alienation of native land) were predicated on the embrace by both the colonized and the colonizers of

\footnotetext{
${ }^{278}$ Ibid., 244.

${ }^{279}$ Leslie James. "Transatlantic Passages: Black Identity Construction in West African and West Indian Newspapers, 1935-1950." African Print Cultures: Newspapers and Their Publics in the 20th Century (2016): 49-74.

${ }^{280}$ The Keys Jan-Mar 1936, 30, quoted in Tignor, Lewis and the Birth of Development Economics. (2006), 37.
} 
the baseless idea that the backward peoples of the world must be civilized. Lewis understood that the British empire and racial discrimination went hand in hand and were both maintained and justified by ideas and assumptions proliferated by knowledge production institutions in Europe.

Thus, as scholarship of the time continued to promote the false myth of "The White Man's Burden," which predicated the colonial system on sympathy and humanitarianism, in The Keys, Lewis took aim at the scholarship emanating from British Universities, which were "amazingly apologetic" towards the British colonial system. Lewis also understood the bitter hostility of British academics to this new generation of Black intellectuals who, as LSE anthropologist Bronislaw Malinowski stated: "turns our own weapons against us. He is studying European aims, pretenses, and all the real and imaginary acts of injustice."281 Demonstrating the validity of Malinowski’s claim, Lewis's 1936 article entitled “Europe’s Impact on Africa,” Lewis reviewed Lucy Philip Mair's Native Policies in Africa, in which he took aim at Mair's support of the British policy of Indirect Rule. Lewis argued that "like all good Lugardites,... [Mair] is suspicious of the educated African, who dares to have his own views as to how Africa should evolve." ${ }^{282}$ With great foresight of the emerging anti-colonial movement, Lewis warned that: "Those who expect Africans to tolerate for generations a system in which every European, however ignorant or uncouth, is an aristocrat, and every African, however cultured, a subordinate, are dreaming a dangerous fantasy." Lewis would substantiate this warning with his own work with the LCP and the Pan-African movement in London.

\footnotetext{
${ }^{281}$ Matera. Black London. (2015), 250.

${ }^{282}$ Ibid., 252.
} 
In 1938, the Colonial Office's West Indies Royal Commission (Moyne Commission) was created to investigate the recent outbreak of labor agitation, strikes, and violence throughout the West Indies. Collaborating with Padmore, Makonnen, and other members of the Pan-African movement, Lewis co-authored a memorandum attributing the labor discontent in the West Indies to the extreme poverty in the region, which he regarded as a legacy of West Indian Slavery. This poverty, according to Lewis, was due in large part to the low prices on West Indian exports of sugar and bananas, which the British government refused to pay a premium for. However, to remedy this issue, Lewis did not suggest raising prices, rather he concluded that the sole long-term solution was industrialization and a radical program for redistributing income from the rich to the impoverished population.

When the Moyne Commission submitted its report in 1939, it recommended the British Government establish a West Indian Welfare Fund to improve education, public health, housing, intensify the agricultural sector. In addition to this, the commission spoke against the "extreme proposals" for immediate and complete self-government. ${ }^{283}$ Lewis and the LCP would publish a critique of the commission's report, in which Lewis objected to the report's weakness on economics. While the report suggested the prospects for industrialization were low in the West Indies, Lewis maintained that the region has vital raw materials and easy access to markets in North and South America, and more importantly what the region lacked was skilled manpower and capital to facilitate industrialization and development. Lewis also chided the commission's report for its failure to discuss the implications of West Indian slavery that created the social

${ }^{283}$ WI Royal Commission, 1938-39, Recommendations, House of Commons Seasonal Papers, quoted in Tignor, Lewis and the Birth of Development Economics. (2006), 46. 
conditions and concentration of wealth that were the root causes of the violence sweeping the region. The Colonial Office was shocked by Lewis' critiques, and while the Office's top economic expert agreed with many of Lewis' suggestions, they resented the fact that he made his objections public instead of privately sharing them with the Office. This would not be the last time the Colonial Office would here from Lewis.

\section{Racial Discrimination and The Colonial Office:}

In the same year, the League of Coloured Peoples protested the British government's discrimination against people of color in the hiring practices of the Colonial Office. Having been denied employment by the Colonial Office based on his race, Lewis jumped at the opportunity to serve on an LCP delegation to press the case against the government's hiring restrictions against Asians and people of African descent. Whereas citing, among several other instances, a May 28, 1938, Colonial Office advertisement for a Jamaican medical officer of European parentage, the League demanded an unequivocal statement against discrimination in hiring and promotions for people of color in the colonial services. However, the Colonial Office maintained that while local colonial peoples could indeed adequately serve in their own native colonies, it was their belief that they would be unwanted in other colonial areas, which was why white Britons were preferred. Furthering the Colonial Office's deflections from the issue of race, Lord Lugard issued a statement claiming that opening the colonial services to every British subject would violate the principle of Africa for the Africans.

In response, the League commissioned Lewis to publish the lengthy correspondence in which the Colonial Office defended its racist hiring practices for public consumption. The correspondence was accompanied by scathing commentary by 
Lewis in which he argued that "Ever since its inception it [colonial employment] has to all practical purposes been reserved to white men to the exclusion of those born within the colonial empire itself." ${ }^{284}$ Lewis shot down the Colonial Office's denial of the existence of racial barriers, citing job listings that required job candidates to be of European parentage, quoting a long list of statements from qualified candidates whose applications had been rejected because of their race. The Colonial Service Recruitment Manual was also cited by Lewis because of its specific reference to the need for candidates to be European parentage. Concluding the publication, Lewis stated that: "Until that determination [race-based hiring] is done away with and people are chosen on merit alone and posted on merit alone in a colony... the basic problem persists." ${ }^{285}$

The public response was overwhelming as the League's correspondence and Lewis's commentary were covered in the Manchester Guardian, the Yorkshire Post, the Liverpool Daily Mail, the Western Mail, the Bulletin and Scots Pictorial, West Africa, the New Statesman and Nation, and several others. The Colonial Office was stung by Lewis' hand in publicizing both the protests of racial discrimination, and his public criticisms of the West Indies Royal Commission's (Moyne Commission) report on labor agitation, strikes, and violence throughout the West Indies. Not only had he exposed their overt racial discrimination, but at a time when Britain was standing alone against the rise of fascism, Lewis likened the British government's bigotry to that one would expect to find in Nazi Germany. Seeking to address the problems of colonial economies in the midst of the second world war, government officials turned to LSE for help and it was swiftly

\footnotetext{
${ }^{284}$ August 1941 of the Newsletter LCP quoted in Tignor, Lewis and the Birth of Development Economics. (2006), 51.

${ }^{285}$ Ibid.
} 
recommended that the seek the services of the twenty-six-year-old Lewis, whom they regarded as a rising star in economics.

Based on the recommendations of his LSE mentors, Lewis was offered a consultant position with the Colonial Office, with the task of preparing a statement on the subject of mining and industrial undertakings in the colonies for post-war reconstruction of the colonies. As such, he had no interest in day to day busy work but was rather interested in taking up policy issues that would promote the economic development of the colonies. Through his work with the Colonial Office Lewis consulted on several issues of colonial economics, industrialization, development, and economic planning. Following Lewis' first report, which demonstrated the how different parts of the British empire were attracted to different capital flows, showcased his capacity for critical analysis and articulation of a high "intellectual standard," the Colonial Office would bring Lewis on to serve on it Colonial Economic Advisory Committee, the Colonial Economic Development Council, and the board of the Colonial Development Corporation throughout the 1940s. Furthermore, while Lewis' opinion was highly valued by government officials, his decision to consult the Colonial Office, in spite of its past racial discrimination, was predicated on his intention and belief that the British system could be rehabilitated from within.

\section{The Fabians and Africa's Man of Destiny}

Joining the reemergent Fabian Society shortly after his arrival in London, Lewis' approach was well within the bounds of their philosophy, which amalgamated the English Liberal tradition, French Positivist doctrine, and mainstream Socialism with the goal of establishing "a society in which equality of opportunity will be assured and the 
economic power and privileges of individuals and classes abolished through the collective ownership and democratic control of the economic resources of the community." 286 The Fabians functioned as an independent research body, with the major purpose contributing new ideas for British Labour Party policy; subsequently, Lewis' role in consulting the Colonial Office on colonial policy to alleviate poverty and promote development in the colonies contributed not only to the Fabian mission but also to the Pan-African and African Nationalist ideals of colonial reform as decolonization approached.

When Lewis arrived in London in the early 1930s, the West Indies was engulfed in political turmoil, brought on by sluggish export, stinginess in the transfer of public funds from London, and declining living conditions, which culminated in strikes and violent confrontations in Jamaica, Trinidad, Barbados, British Guyana, and several other islands. ${ }^{287}$ One of Lewis' initial responses to this was to write a letter in 1935 to John Parker, General Secretary of the New Fabian Research Bureau, in which he stated: "if you do need assistance on the West Indies, I beg to offer my services. I am myself a West Indian student, and have recently been doing a not-inconsiderable amount of research into the history, government, and prospects of the West Indies ... I might add that I am well known to the leaders of the Socialist Party in this school." With the backing of Leonard Woolf who thought that a pamphlet with detailed accounts of history, welfare conditions, politics, and economics in the West Indies from Lewis was "just what is

\footnotetext{
${ }^{286}$ Milburn, Josephine Fishel. "The Fabian Society and the British Labour Party." Western Political Quarterly 11, No. 2 (1958), 322.

${ }^{287}$ Yoichi Mine. "The Political Element In The Works of W. Arthur Lewis: The 1954 Lewis Model and African Development.” The Developing Economies 44, No. 3 (2006), 331.
} 
wanted in the Party."288 This pamphlet, Labour in the West Indies, was eventually published by the Fabian Society in 1939 and became one of Lewis' famous monographs. From this moment forth, Lewis was regarded in political circles as "a close student of Imperial, social, and economic problems who has spoken and written much on these matters" 289

Labour in the West Indies laid the foundations of Lewis' future work on policy proposals for economic development colonial and postcolonial nations. This is manifested in three particular ways. First, Lewis' policy ideas for the Caribbean were emboldened by the strong will for an economic development in which local economic structures should be diversified, and a federalist framework would be established in order to economize the cost of infrastructure. ${ }^{290}$ Second, from a moral and political standpoint, Lewis denounced the monopolistic nature of white planter aristocracy. Instead, he argued for a radical land redistribution policy, which would be accompanied by a large scale educational, financial, processing, and marketing institutions to make peasant production more efficient and competitive. ${ }^{291}$ Thirdly, Lewis entered the political sphere, advocating for popular participation in political life West Indian colonials. For Lewis, land redistribution needed to be accompanied by improved industrial relations and constitutional reform.

In 1940 the Fabian Colonial Bureau(FCB) was created to serve as an independence section of the Fabian Society that was specifically devoted to colonial

\footnotetext{
288 Ibid., 333.

${ }^{289}$ W. Arthur Lewis, Lewis Labour in the West Indies: The Birth of a Worker's Movement, (Fabian Society, 1939), 5. quoted in Mine. "The Political Element In The Works of W. Arthur Lewis." (2006), 332.

${ }^{290}$ Mine. "The Political Element In The Works of W. Arthur Lewis." (2006), 332.

${ }^{291}$ Lewis, Labour in the West Indies 1939, 44-46, 49, 52.
} 
issues. Loosely affiliated to the British Labour Party, which took control of the British Parliament following World War Two, the FCB maintained close ties to the party and its politicians and in most cases defended the government's policies. Black critics of the British government after 1945 came to view the FCB as the "unofficial mouthpiece" of the Labour Party government. ${ }^{292}$ Among the prominent socialist critics of colonial policy within the society, Lewis was selected to serve on the Bureau's executive board, which by the mid-1940s was interested in increasing partnerships between the progressive forces of Britain and those in the colonies.

As a result, when the FCB held a conference in April 1946 on the colonial's criticisms of the Bureau and to exchange views, Lewis was charged with compiling an invitation list of politically active West Indians and Africans in London. ${ }^{293}$ Lewis recommended that the FCB should not seek out solely "bureau buddies and Labour propagandists" to address the conference attendees, rather "it is your enemies you must invite, rather than your friends" that must be engaged in dialogue. ${ }^{294}$ His initial list included H. O. Davis of West African Student Union, and George Padmore of the PanAfrican Federation, who Lewis described as "the centre of opposition among the West Indians." ${ }^{295}$ It is likely that through Lewis' initial inquires for Padmore's participation that Kwame Nkrumah, now the PAF's Secretary-General, was recommended to address the conference. Since Lewis was now a Professor of Political Economy at the University

\footnotetext{
292 Matera. Black London. (2015), 311.

${ }^{293}$ Sherwood. Kwame Nkrumah: The Years Abroad. (1996), 132.

${ }^{294}$ Mine. "The Political Element In The Works of W. Arthur Lewis." (2006), 341.

${ }^{295}$ WAL to Rita Hinden, January 7, 1946, quoted in Tignor, Lewis and the Birth of Development Economics. (2006), 110.
} 
of Manchester, there would have been no overlap between his and Nkrumah's time at LSE and this FCB conference is likely the first meeting of the two men.

As Africans, West Indians, and British Fabians and Labour Party officials gathered for the conference, the now-famous Pan-African leader Nkrumah, was the first speaker in a session entitled: "The Problem of Confidence: Reasons for Distrust on the Part of the Colonial Peoples." In addition to the restating the resolutions adopted at the 1945 Manchester Pan-African Congress, Nkrumah delivered a stiff, militant address condemning colonialism, castigating the Labour Government, and condemning Europe for its role in drawing artificial political boundaries, alienating land and mineral rights and crushing the traditional political and cultural systems that led to "retrogression" in Africa. ${ }^{296} \mathrm{He}$ concluded his speech by stating that:

more gratitude will be shown to the Fabians when they do more when they put into practice their high sounding principles. You can shackle the bodies and feet of men, but not their minds. There is justice behind every historical necessity. The institutions of the colonial world may retreat, but the masses of the colonial peoples have nowhere to retreat. They have only one cry: 'Destroy Imperialism.' 297

Reflecting on the presence of Pan-African anti-colonialists in attendance, Nkrumah's remarks were met with "cries of hear hear and stamping." ${ }^{\text {"298 }}$ The response from the crowd of London's radicalized African and West Indian activist community reflected the culmination of Nkrumah's emergence as a prominent figure in the Pan-African movement, which was now demanding an immediate end to the colonial system instead of the prayers of colonial reform from Black activists of the past.

\footnotetext{
${ }^{296}$ Sherwood. Kwame Nkrumah: The Years Abroad (1996): 132-133; and Mine. "The Political Element In The Works of W. Arthur Lewis." (2006), 342.

${ }^{297}$ Mine. "The Political Element In The Works of W. Arthur Lewis.” (2006), 342.

${ }^{298}$ Sherwood. Kwame Nkrumah: The Years Abroad (1996), 133.
} 
When Lewis ascended the platform to address the conference participants, he delivered a dual criticism of the colonial situation. Lewis' first criticism was directed towards racism as he stated: "The only people who can transform the colonies into anything worthwhile are the educated Natives, intelligentsia...[But] as soon as a Native can read and write, he automatically becomes an opponent of the British Government... Every educated African and colonial knows that he can get the highest qualifications and competence, but he cannot get the highest jobs. He is bound to have to work under a white man who may be even of inferior inability." For Lewis, these comments reflected his own experience with racial discrimination in the hiring practices of the Colonial Office. Lewis leveled his second criticism against the frustrations among his fellow colonial elite, who were "principally interested in acquiring power-few make a serious study of colonial problems and would know what to do if they acquired power. Their frustration distorts their perspectives, makes them ill-informed, strident." Reaffirming his Fabian approach to colonialism and development, Lewis suggested: "The art of democratic government is acquired painfully and gradually, and this is precisely the opportunity which is denied to them."

Addressing his fellow Black intellectual activists, Lewis asserted that "Fabians are never interested in general principles, but in specific problems. A Fabian who gets an itch to do something goes down to Islington looks at the local laundries, and comes back with a red pamphlet report on what is wrong with the laundry system and how municipal ownership would improve it. Then along comes a colonial politician with an eloquent discourse on the general principles of the rights and wrongs of mankind, which the 
Fabian interrupts impatiently with 'Yes, yes . . but what are your laundries like?"'299 Thus, the Fabian approach was concerned with addressing the specific issues of society through gradualist democratic means, and this would be their approach to the issue of colonial policy. Unfortunately, this did not bode well with the radicalized nature of the Pan-African movement, which was now demanding independence and placing violence on the table as a last resort means for ending the colonial apparatus.

In this appeal to the radical Pan-African movement, Lewis was suggesting a waitand-see approach to the FCB and the new Labour government. Since the Labour Party, whom the Fabians regularly advised on colonial policymaking, had seized control of the British government following World War Two, its colonial policy was that of benign trusteeship, meaning that Britain's now flailing post-war economy was now dependent on exports from Africa and the West Indian colonies to replenish foreign exchange reserves within the Empire. ${ }^{300}$ Understanding the principles of Fabian gradualism, as well as the rage derived from the colonial experience, Lewis found himself in a trying position. Concluding his speech, Lewis maintained that "We must give the new Government time, and see what it does ... If it does change we must co-operate. If not, then I agree with the previous speaker: we must push the British out and do the best we can for ourselves."

In spite of these remarks, Lewis, in a letter from later in 1946, appeared to have been skeptical of the Labour Party's command of colonial policymaking and urged the FCB to keep its distance from the Labour government. In a letter to Rita Hinden, Lewis stated that FCB's past activities appeared to render "the bureau to a sort of reformist

\footnotetext{
299 The citation of Lewis's statement is from the pamphlet (Fabian Colonial Bureau 1946, 5-9). in Mine. "The Political Element In The Works of W. Arthur Lewis." (2006), 342.

${ }^{300}$ Ibid., 341.
} 
'leftwing of the colonial office' line, which it may have adopted in practice, but which it has never adopted or intended to adopt in principle." ${ }^{301}$ Thus, with the era of decolonization approaching, Lewis' involvement with the FCB and the colonial policymaking, pushed his focus to the issue of development planning in the colonies.

\section{The Lewis Model for Developing Colonial Economies}

Following the second world war, Lewis's area of specialty had been industrial economics, and the history of the world economy, which he began to study while he was still at the London School of Economics. As Lewis recalled in his Nobel Prize speech in 1979, Frederick Hayek, LSE's chairman of the Economics Department, suggested that Lewis teach a course on the economics of the period between World War I and World War II. Admitting that he very little knowledge of what had happened between the wars, Lewis was told that the best way of learning a subject was to teach it. This ultimately culminated in the first of a dozen influential texts by Lewis entitled, Economic Survey, 1919-38, which was published in London in 1949. This also prompted Lewis to develop special expertise in the economics of the developing world, a topic for which there were no formal curricula at LSE. Motivated by the special interests that students of African and Asian descent had taken in his classes and the ongoing struggle for independence, Lewis undertook the task of investigating and solving the problem of economic development in the tropical colonies.

Although he was from the West Indies and was outspoken on economic development in the West Indian colonies, Lewis maintained a particular interest in

\footnotetext{
${ }^{301}$ Lewis's comment on the draft of Hinden (1946) can be found in: FCB 31/3, ff. 1-4. In Mine. "The Political Element In The Works of W. Arthur Lewis.” (2006), 343.
} 
Africa. In a 1937 article entitled "African Economic Problems," Lewis concluded that the reckless and unregulated quest for wealth that manifested in the industrial revolution in Europe threatened to impoverish the African continent. ${ }^{302}$ By the mid-1940s, Britain was forced to come to terms with this reality, as it turned to its underdeveloped colonies to replenish its post-war economy. As a result, there arose a new emphasis on long-term economic planning to stimulate economic growth. ${ }^{303}$ This culminated in the Colonial Office ordering ten-year development plans be submitted by the colonial Governors in 1944.

In July 1948 Lewis assessed the viability of these ten-year development plans, in a Manchester Guardian article entitled, "Colonial Development: The Defects of the "Plans." In the article, he argued that these plans were unequivocal failures because they had not grappled with the magnitude of what for him was the problem of development. For Lewis, this was the failure of colonial governments to help the people in the colonies to master their environments to make better use of their resources. ${ }^{304}$ In his opinion, "the cart was put before the horse," as governors draw up these ten-year plans without surveying the prospects for economic development and necessitating mass education amongst the peasantry to optimize the agricultural sector. ${ }^{305}$ Furthermore, in many cases, these plans overlooked the central problem of colonial development, which Lewis observed to be the challenge of reforming the existing peasant agricultural sectors.

\footnotetext{
302 The Keys. 1937, 16., quoted in Tignor, Lewis and the Birth of Development Economics. (2006), 35.

${ }^{303}$ W. Arthur Lewis. The Principles of Economic Planning. (George Allen \& Unwin Publishers Ltd, 1969), iv.

${ }^{304}$ W. Arthur Lewis. "Colonial Development: The Defects of the "Plans." Manchester Guardian, July 21, 1948, Lewis Papers, box 37, folder 6.

${ }^{305}$ Lewis. "The Defects of the "Plans." Manchester Guardian, July 21, 1948, Lewis Papers, box 37, folder 6.
} 
Lewis expounded upon his position on the centrality of agriculture to colonial development in his 1949 pamphlet The Principles of Economic Planning, in which he explored the disputes between planning by direction and laisser-faire economics, issues of nationalization, and planning in "backward" colonial societies. Since industrialization was the key to economic development in the colonies, Lewis framed agriculture as "the crux of the problem." ${ }^{" 306} \mathrm{He}$ argued that economic progress in colonial societies necessitated an optimized large-scale agricultural sector, which required fewer laborers and would consequently supply a seemingly infinite labor force to the industrial sector to thrive on. While economic planning was the focus of the pamphlet, Lewis was also beginning to identify the linkages between surplus workers in the traditional agricultural sectors and industrialization. He began to take a particular interest in the large reservoirs of cheap and unskilled labor in the West Indies, Africa, and Asia, compared to the limited and unskilled labor in the English countryside a century and a half ago prior to the industrial revolution in Britain. These initial ideas served as the basis for his dual economy paradigm, which came to be known as the Duel Sector Model, the concept most strongly associated with Lewis to this day.

This model was expounded upon in Lewis' most influential academic publication, "Economic Development with Unlimited Supplies of Labour," which Lewis' sought to address why some countries were wealthy and others were underdeveloped with largely impoverished populations. More importantly, Lewis set forth his own theory on how to raise the living standards of the Third World's poor. In this article Lewis, divided the undeveloped colonial economies into two primary sectors, the

\footnotetext{
${ }^{306}$ W. Arthur Lewis. The Principles of Economic Planning: A Study Prepared for the Fabian Society. (London: George Allen \& Unwin Ltd, 1949), 122.
} 
modern/capitalist/industrial sector, and a backward/traditional/agricultural sector, and stressed the multidimensional nature of economic growth, arguing that no sector should be permitted to progress more rapidly than others. ${ }^{307}$

Lewis' notion of dual-sector development centralized the significance of the unlimited supply of labor for the capitalist industrial sector being drawn from the traditional agricultural sector. Lewis envisioned the main sources of labor for the industrial sector consisting of surplus laborers from the optimized agricultural sector, casual labor, petty trade, domestic service, and migrant labor. Additionally, Lewis included wives and daughters in the household, which was progressive for the time as the divisions of labor in colonial African nations confined women to the agricultural sectors and market economies, thus precluding them from participating in the industrial workforce in many cases. ${ }^{308}$ Furthermore, since this labor in the industrial sector would be available at the minimum wages of the agricultural sector, the economy's employment would expand along with capital formation, making rapid capital accumulation possible.

Additionally, for Lewis, the inefficiency of food production per man in the agricultural sector was the cause of such low prices for exported commercial produce. As a result, Lewis argued that raising the efficiency of "food production would automatically make commercial produce dearer" in international markets and cheaper domestically. ${ }^{309}$ Thus, productivity gains from the agricultural sector and the reinvestment of profits in the

\footnotetext{
307 Charles M. Becker and Terry-Ann Craigie. "W. Arthur Lewis in Retrospect." The Review of Black Political Economy 34, no. 3-4 (2007), 196.

${ }^{308}$ W. Arthur Lewis. "Economic Development With Unlimited Supplies of Labour." The Manchester School 22, no. 2 (1954), 189; Ralph A. Austen. African Economic History: Internal Development and External Dependency. (London: James Currey, 1987), 139. Gregory H. Maddox, James L. Giblin, and Isaria N. Kimambo, eds. Custodians of the Land: Ecology and Culture in the History of Tanzania. (Athens: Ohio University Press, 1996) 221.

${ }^{309}$ W. Arthur Lewis. "Economic Development with Unlimited Supplies of Labour." (The Manchester School 22, no. 2 (1954), 191.
} 
industrial sector would lead to growth in the total output of goods. This, according to Lewis, was one of the senses in which industrialization was dependent upon agricultural improvement; as it was not profitable to produce a growing volume of manufactures unless agricultural production is growing simultaneously. ${ }^{310}$ It was also why Lewis suggested that "industrial and agrarian revolutions always go together, and why economies in which agriculture is stagnant do not show industrial development" ${ }^{\prime 11}$ As such, under Lewis' model, the capitalist sector expands, with profits growing relatively, and an increasing proportion of national income being re-invested in the nation's economy. ${ }^{312}$ This was the result that emerged from the Duel Sector Model.

Lewis" "Economic Development with Unlimited Supplies of Labor" was possibly the most influential essay in the field of development economics as one of the most cited essays of the 1950 and 1960s, and still read by aspiring economists to this day. The notion that broadly rising prosperity requires concurrent productivity growth in agriculture and industry, made possible by unlimited supplies of labor from the subsistence sector, had a place not only Lewis but the field of Development Economic on the map of the economic profession. Lewis' centralizing of "the concept of 'agrarian excess' or 'surplus population' or 'disguised unemployment in agriculture' was what distinguished him from economic literature of the past, and the immediate impact of the article placed these concepts in fore of all conversations regarding economic planning and development in the colonials. ${ }^{313}$

\footnotetext{
${ }^{310}$ Lewis, "Unlimited Supplies of Labour," (1954), 171-76.

${ }^{311}$ Ibid., 171-76.

312 Ibid., 190.

313 Tignor, Lewis and the Birth of Development Economics. (2006), 96-97.
} 
A year later, Lewis expounded upon his ideas on development further in his text, Theory of Economic Growth, which soon became a major contribution to the emerging field of development economics. Focused on economic growth, or rather the growth of output per head, Lewis drew on his extensive knowledge of history, humanities, and economics to emphasize that all elements of society, including social structures, political systems, scientific knowledge, and religious doctrine, have a direct impact on economic growth. ${ }^{314}$ Seeking to understand the fundamentals of economic growth, as well as why that growth was confined to certain societies, Lewis identified three primary causes of wealth and poverty including the will to economize, the accumulation of knowledge, and the accumulation of capital. ${ }^{315}$ In doing so Lewis, underscored the significance of the fundamental changes in attitudes, belief systems and institutions to cultivate the will to economize, the greater importance to mass education for the accumulation of knowledge, and the role of the government as an instrument of capital accumulation. ${ }^{316}$

In addition to this, Lewis reiterated his belief in government-directed economic planning, which he envisioned to include government spending on public works and utilities working in tandem with regulated private sector initiatives. Still, Lewis, was wary of the shortcomings of centralized government planning in that all too often become "undemocratic, bureaucratic, inflexible, and subject to error and confusion" as governments became overly ambitious in their plans. Lewis preferred a "piecemeal planning" approach that focused on a shortlist of initiatives such as capital formation, food production, or industrialization and "leaving the rest of the economy to adjust itself

\footnotetext{
${ }^{314}$ Dudley Seers, West Africa, January 28, 1956, 85.

315 Tignor, Lewis and the Birth of Development Economics. (2006), 103.

${ }^{316}$ W. Arthur Lewis. Theory of Economic Growth. (Homewood, Ill., 1955)
} 
to demand and supply." 317 Furthermore, beyond shortages of capital, skilled labor, and foreign exchange, the particular political and social conditions faced by underdeveloped colonial nations necessitated individualized government plans for economic development.

The Theory of Economic Growth was concise and written to appeal to a broad audience of non-economic specialists; however, for economists, the text had broken new ground and provided hypotheses and theoretical models for an emerging field that were primed for testing as decolonization escalated. As a result, in the 1950s Lewis quickly emerged as one of the most innovative and prominent scholars of development economics. His views on economic planning, his "Theory of Economic Growth," and the significance of optimizing the agricultural sector as a prerequisite to industrialization had become attractive not only to his students and colleagues in the academy, but to the British Colonial Office, the United Nations, and colonial governments pushing for independence as well. Lewis became well sought especially among African nationalists, many of which were educated in London where his reputation as a scholar and extensive work in the Colonial Office, the League of Coloured Peoples, and The Keys placed him in high regard. Having participated in the Pan-African movement as a member of the League of Coloured Peoples, and working alongside George Padmore, C.L.R. James, and Ras Makonnen in the past made him, Lewis an ideal candidate for Kwame Nkrumah to consult on matters of economic development in Ghana.

${ }^{317}$ Ibid., 384. 


\section{Lewis's Contributions to the Gold Coast Revolution}

Two years after addressing the Fabian Colonial Bureau's conference on relations between the FBC and the Colonial Office, both Lewis and Nkrumah had departed London to further their careers. Lewis, after being denied a professorship at the University of Liverpool for being of African descent, had been hired at the University of Manchester in 1948, becoming Britain's first Black University Professor. Whereas Nkrumah had returned to the Gold Coast to serve as the United Gold Coast Convention's General Secretary and deliver the final blow against British colonial rule. While Nkrumah was organizing a nationalist mass movement, winning elections from prison, and by 1951 entering an era of what historian, Ama Biney, called the "Dyarchic Partnership," reflecting the sharing of power-sharing between Nkrumah and the CPP , and the colonial governor, Sir Charles Arden-Clarke, Lewis had been gathering his thoughts for his Dual Sector Model, and training a new generation of African and Asian economists at the University of Manchester.

In addition to this, Lewis was heavily involved with the Black activist community in Manchester. The site of the storied 1945 Pan-African Congress, Manchester the home of the Pan-African Federation's headquarters and during the early 1950s, Lewis collaborated with Ras Makonnen, a seasoned Pan-African activist and mentor of Kwame Nkrumah, on several initiatives for the Black community in Manchester. Lewis and Makonnen's work included collaborating with several organizations including the West Indian Social Club, the Negro Association, the African Students Union, and the Gold Coasts Brotherhood. Lewis was also regularly featured in British print media and the British Broadcasting Corporation speaking on the state of colonial economics, especially 
in Africa. As a result of his notoriety in Britain as an expert on colonial and development economics, his ongoing work with Makonnen, as well as his distinguished reputation amongst the African Nationalists living in Britain, Lewis' expertise and services were requested by Nkrumah as the Gold Coast entered the phase of decolonization and independence approached.

In the early 1950s, Gold Coast society possessed extremely high political, regional, ethnic, and religious tensions and division; however, it was a colony with tremendous economic potential. As Nkrumah built a populist-nationalist movement with a political base in the southern coastal region, the Asante region was home to the colony's largest source of cocoa production as well as Nkrumah and the CPP's largest and most formidable opposition. Seeking to use the profits generated from the booming cocoa sales of the post-war years for economic diversification and development, the British and nationalists in the Gold Coast viewed cocoa as the colony's key to industrialization and modernization. ${ }^{318}$ Regarded as the model African colony, the Gold Coast had a relatively high standard of living compared to other tropical colonies, heighten prospects for economic growth, a multigenerational tradition of educated elites with strong connections to British colonial officials, established private British firms, and no white settler population. ${ }^{319}$ Furthermore, while it was believed that the Gold Coast had

\footnotetext{
318 The rise in cocoa sales following World War II were due to the continuation of a number of British wartime schemes, including the creation of cocoa marketing boards and government controlled prices that ensured supplies of low cost cocoa to Britain from its West African colonies, which accumulated U.S. dollars on the world market and allowed Britain to build up a sizeable profit on its cocoa transactions. For more on this see: David Meredith. "The Colonial Office, British Business Interests and the Reform of Cocoa Marketing in West Africa, 1937-1945." Journal of African History (1988), 298; Merrill J. Bateman. "Aggregate and Regional Supply Functions for Ghanaian Cocoa, 1946-1962." Journal of Farm Economics 47, no. 2 (1965), 399; and Alence, Rod. "Colonial Government, Social Conflict and State Involvement in Africa's Open Economies: the Origins of the Ghana Cocoa Marketing Board, 1939-46." The Journal of African History 42, no. 3 (2001), 397-416.

319 Tignor, Lewis and the Birth of Development Economics. (2006), 113.
} 
more opportunity for development than anywhere else in Africa, the British Colonial Officials charged with overseeing economic planning were adept in finance (i.e. creating budgets and tax codes) but possessed very little background in creating the comprehensive plans for long term economic growth that were now being addressed in the emerging field of development economics.

As Lewis had observed in 1948, the ten-year plans for the colonies were unequivocal failures and in its review of the plan for the Gold Coast, the Colonial Office deemed a bad plan that was weak on economics, agriculture, and use of land. ${ }^{320} \mathrm{Sir}$ Andrew Cohen, then the Colonial Office's Assistant Undersecretary for African Affairs observed that there were good relations between the government and the people, plenty of money and great economic potential; however, there appeared to be little thought "devoted to the problem of developing the natural resources," which he perceived as "a gap in what I think is an otherwise thoroughly happy picture." 321 The current plan which devoted 59 percent of expenditures of railways, harbors, education, and public, and a mere 17 percent to industrialization and agricultural development, risked the colony facing rising annual expenditures with no guaranteed sources of revenues if or when the post-war cocoa boom waned.

Cocoa was king in the Gold Coast during the decolonization era. From the Great Depression until World War II, world cocoa prices were low and controlled by British colonial marketing boards; however, once wartime rationing came to an end the world's

\footnotetext{
${ }^{320}$ Lewis. "The Defects of the "Plans." Manchester Guardian, July 21, 1948, Lewis Papers, box 37, folder 6.

${ }^{321}$ Note by A. Cohen, on the Gold Coast Ten-Year Plan, February 27, 1947, PRO CO 96/806/1, quoted in Tignor, Lewis and the Birth of Development Economics. (2006), 114.
} 
overindulgence of chocolate and its price both skyrocketed. ${ }^{322}$ As a result, the Gold Coast Marketing Board, to the dismay of the Gold Coast cocoa farmers, chose to pay cocoa farmers well below the world price and placed cocoa profits into gilt-edged securities high-grade bonds issued by the British government to generate post-war revenues - in London to be used in case the world prices plummeted and for development projects. J.B. Danquah, a prominent leader of the UGCC and a representative of the Gold Coast cocoa producers on the board, opposed cocoa surpluses being used for long term development projects. Danquah charged the Gold Coast Marketing Board with being more interested in development rather than the welfare of the cocoa producers, which was an accurate assessment as increasing profits to export-import firms and expanding harbors were logical objectives of any colonial economy. ${ }^{323}$ Nonetheless, the state embraced the idea of using the cocoa surplus for development to spur economic diversification, transform the Gold Coast's dependence on a single export crop economy, and raise the nation's standard of living.

Once Nkrumah had been elected Leader of Government Business in February 1951, he and the Colonial Governor, Sir Charles Arden-Clarke, were in agreement that with regards to the cocoa industry, it was the government that should control all matters of policy that affected national interests, including cocoa prices and surpluses. Furthermore, after forming the new government, Nkrumah swiftly passed legislation that reduced the membership on the cocoa marketing board from twelve to seven and place the board under the authority of the Minister of Commerce and Industry, K. A.

\footnotetext{
322 Alence. "Colonial Government, Social Conflict and State Involvement in Africa's open Economies: the origins of the Ghana Cocoa Marketing Board, 1939-46." (2001), 412.

${ }^{323}$ Tignor, Lewis and the Birth of Development Economics. (2006), 118.
} 
Gbedemah, whom Nkrumah had appointed himself. Nkrumah reorganized the board seats with the goal of placing national interests above all other agendas as opposed to "the extreme sectoral and regional representation" of the formerly Danquah led boards. As the cocoa industry experienced unprecedented prosperity, surpluses approach $£ 80$ million, Danquah who believed the funds should be invested in gilt-edged securities instead of being "frittered away by power-drunk politicians in their wild-cat schemes of unreal paradise for Ghana." 324

Danquah's comments reflected a growing discontent between Nkrumah's central government and Asante, the nation's largest cocoa producing region, over not only the use of cocoa profits but more importantly the future of the nation. In spite of these disagreements, the Colonial Office maintained that economic progress was vital for any prospects of decolonization and the eventual transfer of power to the Gold Coast Nationalists. As such, these new developments in the cocoa industry necessitated a reassessment and revision of the colony's ten-year plan with a particular emphasis on industrialization. Taking up this task, Nkrumah and the CPP allocated more funds to economic growth and development, and Nkrumah himself was named chairman of the new development committee. With control over the direction of development, Nkrumah, in search of an expert to draft plans for industrialization, turned to W. Arthur Lewis.

\section{Industrialization in the Gold Coast}

In 1950, Lewis concluded that while colonial peoples were eagerly interested in the prospects of industrial development and that in several cases it was vital to their

\footnotetext{
${ }^{324}$ J. B. Danquah, Chairman of the Parliamentary Committee of the UGCC, to Secretary of State May 25, 1951, quoted in Tignor, Lewis and the Birth of Development Economics. (2006), 122.
} 
progress; however, the ten-year plans approved in the mid-1940s showed at most token provisions to implementing modern techniques of state-sponsored industrial development. ${ }^{325}$ As such, when Nkrumah and the Gold Coast government requested Lewis' assistance in investigating the prospects for industrialization, he eagerly accepted. Entering the politically charged economic situation was the optimistic Lewis, who along with his wife and daughters visited the Gold Coast from December 15, 1952, to January $4,1953 .{ }^{326}$ On this trip, Lewis traveled the colony extensively. Covering 1,800 miles by road and air to visit industrial establishments and speak with as many people as possible. All of his research culminated in a seventy-page report that was published by the Gold Coast Government for wide circulation in 1953.

Lewis wasted no time as he opened the report with a concise overview of the best ways to industrialize the Gold Coast, which in his view started with: (1) the processing for export of primary products (agricultural or mineral); (2) manufacturing for an expanding home market; and (3) manufacturing for export of light manufactures, often based on imported raw materials. ${ }^{327}$ At the time, Lewis concluded that the third component of industrializing was out of reach as the Gold Coast did not possess the cheap skilled labor for light manufacture exporting; however, this was the case for most developing nations. As it concerned the processing of primary products for export, Lewis noted that, outside of cocoa and palm kernels and oil, the only processing industry with promise was the industry, as the Gold Coast was equipped with large forests and cheap labor to cut and process the timber for export. Coming as a shock to most of the radical

\footnotetext{
325 "Development Planning in the UK Colonies." (1950), 9, Lewis Papers, box 30, folder 3.

${ }^{326}$ Lewis to Gold November 24, 1952, Lewis Papers, box 6.

${ }^{327}$ W. Arthur Lewis, Report on Industrialization and the Gold Coast (Accra, 1953), 1, Lewis Papers, box 21 , folder 4 .
} 
nationalists in the CPP, Lewis viewed the Gold Coast's number one priority to industrializing was in agricultural improvement.

Years before his article "Unlimited Supplies of Labour" was published, Lewis argued in his Report on Industrialization and the Gold Coast that "If agriculture is stagnant, industry cannot grow." ${ }^{\prime 28}$ While the Gold Coast's primary export of cocoa was believed by most to have unprecedented economic potential, Lewis' concluded from his survey that productivity in the agricultural sector, including cocoa, showed very little sign of an increase and "almost certainly stagnant." 329 In his opinion, agricultural production per person outside of the cocoa industry was constant, and probably in decline for the cocoa industry. As such, Lewis asserted that the key to industrialization in the Gold Coast was to take aggressive means to increase food production, which he believed to be the surest was of creating a large demand for manufacturing without which there could be little industrialization. In addition to this, Lewis understood that high standards of living could not be reached in an economy in which half of the people are scratching the ground for food with a hoe. Thus, for Lewis, a food industry that optimized production with fewer farmers producing more, would eventually provide labor and stimulate the industrial sector of the economy.

In his assessment of the industries to be invested in, Lewis found that the home market to be restricted. The industries with favorable prospects were salt, beer, lime, bricks and tiles, cement, and industrial alcohol. Lewis deemed cigarettes, foundry products, weaving cotton and rayon, and rubber manufacturing, as marginal industries. These lists were so short first because the Gold Coast did not have many industrial raw

\footnotetext{
${ }^{328}$ Ibid., 2.

${ }^{329}$ Ibid., 2.
} 
materials, and second because the demand for textiles was rather small; however, he believed the list would grow as the standard of living rose. Lewis placed the investment figures for these industries at $£ 3$ million per year; however, it was not the state that he believed should undertake the investing. Since squeezing $£ 3$ million a year out of the people of the Gold Coast could not be done without lowering their standard of living, cause discontent among the masses with any government, Lewis recommended government funds be invested in the agricultural sector. As a result, it was clear to Lewis that industrialization was impossible in the Gold Coast without foreign private capital and the knowledge of expatriates. Furthermore, Lewis maintained that the most pressing question would always be the terms on which foreign enterprise came and how much of their own capital they would invest. ${ }^{330}$

Concluding the report, Lewis prioritized agricultural modernization since agricultural productivity per man was stagnant. Doing so would increase productivity, and provide the market, the capital, and the labor for industrialization. Lewis recommended next prioritizing improving public services, which would reduce the cost of manufacturing in the Gold Coast and attract new industries. He also maintained that while increasing the manufacture of commodities for the home market deserved support, it should not be a priority and any major programs for it should be implemented once the nation was prepared to carry it out. Very many years, Lewis concluded, would have to elapse before it became economical for the government to make major investments of its own resources towards industrialization. As such, foreign capital was necessary and should only take place on favorable terms for the Gold Coast government. This presented

\footnotetext{
${ }^{330}$ Ibid., 8.
} 
a number of conundrums for the Gold Coast as it sought to sever its ties to Britain, as doing so with an assertive or contentious stance could jeopardize access to British capital. On the other hand, acquiescence to the terms of British capital could potentially undermine the modernization aspirations that Nkrumah possessed for building an industrialized and economically independent nation and raising the living standards of Ghanaian citizens.

Furthermore, among the terms, proposed by Lewis were only supporting industries that could be established without large and continuing subsidies, working with firms that were willing to train and employ Africans in senior posts, free transfers of profits and dividends, and fair compensation if nationalization took place. ${ }^{331}$ In addition to this Lewis recommended the government establish an Industries Division in the Department of Commerce, abolish import duties on industrial raw materials, construct a first-class hotel in Accra, and increase the staff of the Industrial Development Corporation for research, advising new industries, administering industrial estates, and operating government-owned factories. ${ }^{332}$

Lewis' report was well received by the staff in the Colonial Office, who praised the pragmatism of his recommendations. For the radical members of the CPP, who had been enamored by the writings of George Padmore, Marx, and Lenin, the conservatism of Lewis' report and his recommendations for attracting foreign private capital for industrialization to take place must have been difficult to read. The report was still respected and held in high regard in their public pronouncements. In a letter in June 1952, K.A. Gbedemah, Nkrumah’s appointed Minister of Commerce and Industry,

\footnotetext{
${ }^{331}$ Ibid., 22.

${ }^{332}$ Ibid., 21-23.
} 
thanked Lewis for a "lucid and comprehensive document" that "will be of the greatest value to the Gold Coast Government in formulating an economic policy for future industrial development." ${ }^{" 33}$ A month later he wrote Lewis again to inform him that the Gold Coast government had approved the report for publication at once. ${ }^{334}$ Still, when Gbedemah mentioned the government, he was referring to the government that had been put in place by Nkrumah and the CPP that was now partnering with the British Colonial government.

While Nkrumah and the Colonial Office praised Lewis' findings, the report and Lewis himself became a regular topic of debate in the Legislative Assembly, as ongoing debates on development and industrialization took place. When asked about the government's plans to encourage development and the establishment of industries in the Gold Coast, Mr. E. K. Bensah, the Ministerial Secretary to the Ministry of Commercial and Industry, announced that the government had adopted a general policy of promoting development and establishing new industries through the Industrial Development Corporation (IDC). He maintained; however, that the IDC could not cover the total costs of financing this development and industrialization and, that it would be the government's policy to seek investment from foreign capital. ${ }^{335}$ This general policy of the government, Bensah reiterated, was to be presented in full once Professor Lewis' Report on Industrialization and the Gold Coast, was completed.

Once the report was published and placed in circulation, it was regularly cited by representatives for matters of development and industrialization, but also for the on-going

\footnotetext{
${ }^{333}$ K.A. Gbedemah to Lewis June 30, 1953., Lewis Papers, box 6.

${ }^{334}$ K.A. Gbedemah to Lewis July 15, 1953., Lewis Papers, box 6.

${ }^{335}$ Gold Coast, Legislative Assembly Debates, March 9-18, 1953, 1059, GH/PRAAD/ADM/14/2/77.
} 
debates over Africanisation of the Civil Service in the Gold Coast. In November 1953, J. K. A. Quashie, a CPP representative of the Volta region, referred to Lewis' report in support of the training that was necessitated by Africanisation. Specially Quashie quoted Lewis' recommendations of sending young people abroad to firms in Britain, India, Japan, or any country that would agree to have them for training. And upon their return, these specialists would have received enough training and experience to go into business on their own, work in existing firms, or in Government service. ${ }^{336}$ Quashie's comments reflected not only the prolonged debate regarding the employment and promotion of qualified and experienced Africans in administrative and supervisory positions in the civil service, but also the applicability of Lewis' report to varying issues of Gold Coast society.

When the Legislative Assembly debated the budget in February 1954, Nkrumah announced that the government had accepted Lewis' report and his recommendations for industrialization. Nkrumah seemingly resolved to Lewis' findings announces that "it will be many years before the Gold Coast will be in a position to find from its own resources people who combine capital with the experience required in the development and management of industries. It is therefore apparent that the Gold Coast must rely to a large extent on foreign enterprise, and the government is anxious to give it every encouragement." 337 Nkrumah appeared to be enthused and in agreement with the report assessments as he echoed Lewis' recommendations on foreign firms training and promoting African personnel, welcoming foreign investment, promising to place no

\footnotetext{
${ }^{336}$ Lewis, Report on Industrialization and the Gold Coast (1953), 12., Lewis Papers, box 21, folder 4.

${ }^{337}$ Gold Coast, Legislative Assembly, February 17, 1954: 1082-83, quoted in Tignor, Lewis and the Birth of Development Economics. (2006), 126.
} 
restrictions on the repatriation of profits, and fair compensation if nationalization were to take place in the future.

Although Nkrumah had built a mass nationalist movement and was the Colonial Office were in agreement with Lewis' observations and sounds recommendations for industrialization, the Gold Coast was still in political turmoil. In spite of Lewis' acclaimed report, J. B. Danquah, leader of the UGCC opposition party, unable to object to the report, was confined to complaining that the CPP did not know what to do about industrialization until "a West Indian Negro called Professor Lewis came here for a fortnight's visit and made a survey of the country's needs." 338 Declaring that Lewis had not told them anything they had not already known, Danquah argued that actually what the nation needed was a new government that would carry out these industrialization schemes with vigor.

Reflecting the politically charged speech of an oppositional party leader with an election year approaching, Danquah took this as an opportunity to denounce the efforts of Nkrumah and the CPP, and assert that if his party were in office "we would change the face of the country." 339 Shortly after this Kwame Nkrumah and the CPP would go on to sweep the Gold Coast's 1954 elections, and swiftly freeze the price paid to cocoa farmers at 72 shillings a load, even though the world price was sharply increasing. ${ }^{340}$ This prompted the formation of the National Liberation Movement (NLM) in the Asante region, which was followed by nearly two years of violence between CPP and NLM

\footnotetext{
${ }^{338}$ Gold Coast, Legislative Assembly, Debates, February 11, 1953, 83, quoted in Tignor, Lewis and the Birth of Development Economics. (2006), 127.

${ }^{339}$ Gold Coast, Legislative Assembly, Debates, March 13, 1953, 83, quoted in Tignor, Lewis and the Birth of Development Economics. (2006), 127.

${ }^{340}$ Florence Mabel Bourret. Ghana, the Road to Independence, 1919-1957. (Stanford, Calf.:

Stanford University Press, 1960), 187.
} 
members, in the form of bombings, assaults, and several political murders. In the midst of this political unrest, Lewis' services were requested on a regular basis by Nkrumah and his administration.

\section{What Would Lewis Do?}

Lewis would continue to visit the Gold Coast throughout the rest of the 1950s, as Nkrumah and Gbedemah would turn to him for his advice regarding issues of economic development, industrialization, and the Volta River Scheme. Although Lewis' recommendations allowed for the emerging ideas from development economics to influence many of the economic programs in the final years of colonialization, the official architect of economic development in the Gold Coast was Kenneth Tours. The Cambridge educated, British national, Tours had been loyally serving in the Gold Coast colonial administration since 1931 . Holding several positions during his nearly thirtyyear tenure with the British Colonial Office, he was appointed Minister of Finance in 1954 for a brief period and served as the government's Economic Advisor from 1954 to 1956. While this was the very position that Lewis would hold in the near future, Tours' appointment was ultimately counterproductive to Nkrumah's economic aspirations as he was far from an expert in development economics, nor was he an economist.

Tours' predecessor and former Minister of Finance, R. P. Armitage, believed that the Gold Coast needed, for his replacement, a financial and economic adviser with vast knowledge and experience in financial and economic matters not only in Africa but other parts of the world. Armitage appeared to be describing an individual of Lewis' stature; however, the Colonial Office, in spite of his bold and seemingly reckless financial proposals for the Gold Coast's surging cocoa surpluses, opted to promote Tours instead. 
Far from a trained economist, Tours' rarely considered the political implications of his proposals, which he himself characterized a "nuts," as the Gold Coast nationalists became increasingly divided on the question of cocoa in the mid-1950s. ${ }^{341}$ Additionally, his promotion, no doubt, contributed to the frustrations regularly expressed in debates in the Gold Coast Legislative Assembly regarding the Africanization of the civil service. Nonetheless, Tours began his tenure as Minister of Finance in 1954 with the backing of not only the Colonial Office, but also Nkrumah, and Gbedemah, both of whom were seeking transformative proposals for rapidly developing the Gold Coast's economy.

In his first budget speech in February 1954, Tours underscored the necessity of becoming more than a single crop exporting economy. Seeking to capitalize on the booming cocoa prices on the world market, Tours thought it best to increase cocoa production and for the state to retain the surpluses to carry out the ten-year economic plan as rapidly as possible. Tours and Nkrumah were both in agreement about it being counterproductive to return funds back to the cocoa farmers and preferred making the nation, as a whole, the beneficiaries of the cocoa industry. He also increased government expenditures to $£ 2$ million a year for projects with immediate payoffs. Tours believed this would enhance tax revenues and enable the government to set aside special funds to finance its second development plan and the Volta River Project, which was a focal point of Nkrumah's plans for industrialization and nation's future as the epicenter of PanAfrican unity for the African continent. While, the Colonial Office was skeptical of these plans from their initial proposals; however, they offered no objections in fear of jeopardizing Tours' influence on Nkrumah.

${ }^{341}$ Tignor, Lewis and the Birth of Development Economics. (2006), 131. 
By 1955 it had quickly become apparent that Tours' plans had gone awry. His plans ignored Lewis' recommendations, as they placed an overemphasis on industrialization, neglected agriculture, and further alienated the cocoa-producing regions of the colony, which by that time had consolidated under the National Liberation Movement. Additionally, Tours had overlooked Lewis' suggestions on keeping government expenditures low and by late 1955 feared funds from the increased cocoa duty would be swallowed by the rapidly rising recurrent annual expenditures. The Gold Coast's worrisome financial situation was made clear in the government's 1955 Development Progress Report, which revealed that resources were stretched thin and the ten-year plan was behind schedule. Interestingly enough, the Report cited Lewis's report on industrialization several times regarding the nation's desperate need to increase food production for economic development to take place. According to historian, Robert Tignor, Tours seemed haunted by Lewis, as the economic planners in the Gold Coast government increasingly referred back constantly to Lewis' report as a guide and with a disposition of "what would Lewis do?"342

The same was true for Tours, who throughout his tenure as Minister of Finance and Economic Advisor, remained in contact with Lewis from whom he sought approval of his plans. One such example of this came in early 1955 when Tours wrote to Lewis regarding his own ideas on lowering the nation's Company Tax. Also since Lewis had also been consulting the Gold Coast government on the Volta River Project (VRP) since 1952, Tours requested that Lewis verify that his calculations based on Lewis' most recent report "meets the case as you meant it to be met." ${ }^{433}$ In his response to Lewis noted that

\footnotetext{
${ }^{342}$ Ibid., 136.

${ }^{343}$ Tours to Lewis, March 8, 1955, 2., Lewis Papers, box 13.
} 
his reaction was negative, as Tours' proposal for the Company tax made it "too easy to evade" and created unfair taxation between certain companies. ${ }^{344}$ Lewis maintained that no country had these kinds of taxation for these reasons. Regarding the new VRP, Lewis noted that Tours' calculations were premature as the 1956 budget had not yet been approved and negotiations had not concluded. Furthermore, while Tours believed his ideas to be innovative and radical for spurring economic development, his proposals merely revealed his own nescience to economic planning.

Lewis' perfunctory responses reflected the dynamic of the relationship between him and Tours. On multiple occasions during Lewis' visits to the Gold Coast to consult on the VRP, Tours was known to chase "Lewis like a bloodhound" between meetings from seminar room to seminar room to hastily present his ideas for Lewis's approval. ${ }^{345}$ Conversely, in situations where Lewis objected to his plans, Tours would often dismiss Lewis as "an ivory-towered academic [who was] out of touch with the harsh political and economic realities of the Gold Coast." ${ }^{\text {"346 }}$ Reflecting the deteriorating outlook on the Gold Coast's prospects for capitalizing on its cocoa surpluses, Tours reported to the Colonial Office that Lewis confessed he "thanked God that he was not responsible for that [the Gold Coast finances]." ${ }^{\prime 37}$ Lewis' remarks were corroborated when Tours reported that all of the Gold Coast's revenue sources, including the cocoa duty, would be used to balance the new regular budget.

\footnotetext{
${ }^{344}$ Lewis to Tours, April 1, 1955, 1., Lewis Papers, box 13.

${ }^{345}$ Tignor, Lewis and the Birth of Development Economics. (2006), 136.

${ }^{346}$ Ibid.

${ }^{347}$ No. 24, K. Tours to R.J. Vile, October 10, 1956, quoted in Tignor, Lewis and the Birth of Development Economics. (2006), 136.
} 
Interestingly, this budget was expected to go into deficit and cocoa prices were projected to plummet during the next fiscal year, which also conveniently coincided with the nation achieving independence. When the Colonial Office declared the prosperous years over in the Gold Coast at the end of 1956, Tours quickly departed, blaming his failures on Lewis' influence on Nkrumah, and racial stereotypes, claiming the African habit of mind was predisposed to "always lives beyond income." 348 However, it was not lost on the Colonial Office, nor Lewis, that even with Tours' economic plans depleting the cocoa surpluses, the Volta River Project seemingly dead in the water, and the development plan in disarray, Ghana's great economic potential endured, if the country's resources could be operationalized efficiently and creatively.

\section{Independence and Courting Lewis to Work in Ghana}

Despite Tours' handling of the economic situation, the British granted independence in March 1957, and Lewis, like several prominent figures from the African world, was in attendance for the celebrations in Accra. The same euphoria brought on by independence and a promising future on that Ghana represented for the African continent and the diaspora was not lost on Lewis. His own Pan-African sympathies dated back to his childhood when his father would take him to hear Marcus Garvey speak. During his time in London, Lewis regularly collaborated with the Pan-African Federation and its founding members, a number of whom were still close advisors to Nkrumah since he returned to Ghana in 1947. Among these advisors was C.L.R. James and George Padmore, whom Lewis met with regularly when he lived in London and received regular

\footnotetext{
${ }^{348}$ Ibid., 137.
} 
updates on Nkrumah's progress towards achieving independence throughout the $1950 \mathrm{~s} .{ }^{349}$ Additionally, with Ghana in need of a new Economic Advisor, Lewis' activist work in London and his standing as a foremost expert on development economics made him a natural candidate for the roster of prominent Pan-African figures that Nkrumah was assembling for his administration.

As such, in the weeks following Ghana's independence celebrations, Nkrumah offered Lewis a position as the endowed Chair of Applied Economics at the University of Ghana. Lewis rejected this initial offer, admitting that he had been at research institutions his entire career and that instead of teaching undergraduates at the University of Ghana, his next career move would likely be into administration, as he was already serving as the Dean of the Faculty of Economic and Social Studies at the University of Manchester. ${ }^{350}$ He had also recently rejected an offer of the position as Principal of the University College of the West Indies, citing unfinished research that he needed to complete. However, since his attempts in the 1930s to work for the Colonial Office in the West Indies, Lewis maintained a strong commitment to contributing to the development of the region he called his home. As such, he admitted to Nkrumah that he expected "if the job is offered to me [again], I shall probably accept and do the best I can."351 Still, Nkrumah was persistent in seeking Lewis' services in Ghana.

Next Nkrumah offered Lewis a lifetime contract to serve as the Ghanaian government's Economic Advisor. This was a position that piqued Lewis' interest, as Ghana stood to be a perfect testing ground for his theories on development economics.

\footnotetext{
${ }^{349}$ Lewis to George Padmore, January 25, 1956, and Lewis to George Padmore, February 16, 1956, Lewis Papers, box 10, folder 6 .

${ }^{350}$ Lewis to Kwame Nkrumah, April 2, 1957, Lewis Papers, box 9.

${ }^{351}$ Lewis to Kwame Nkrumah, April 16, 1957, Lewis Papers, box 9.
} 
Furthermore, racial liberation and remedying the issue of economic under-development in the impoverished nations of the world were two of Lewis' passions, and advising the first African nation to achieve independence presented an alluring prospect. As such, Lewis tentatively accepted the position on May 29, 1957; however, understanding the intertwined nature of economic policy and politics, Lewis was wary of being too closely aligned with the leader a ruling party in a nation as politically divided as Ghana. As a result, Lewis requested that Nkrumah seek his services through the British Government or the United Nations, who had placed Lewis amongst its own select "Group of Experts on Under-developed Countries in 1951" and had appointed him as a consultant to the Gold Coast Government in 1953. ${ }^{352}$ Acquiescing to Nkrumah's request, the United Nations Technical Assistance Administration assigned Lewis to work in Ghana in the Office of the Prime Minister to "give advice on such questions as the Prime Minister refers to him from time to time." 353

After Lewis was assigned a top U.N. salary at the time of $\$ 12,000$, the University of Manchester granted Lewis' request for a two-year leave of absence and his position was official. Subsequently, while the British government recognized that Lewis possessed extensive knowledge of the economic situation in Ghana, his socialist principles were a cause of concern. Still, they had observed "Lewis is a socialist, but a moderate one," and with his influence on Nkrumah, they believed that Lewis could "be a useful counterweight" to the lefts, like George Padmore and Geoffrey Bing, that

\footnotetext{
${ }^{352}$ Lewis to Kwame Nkrumah, May 29, 1957, Lewis Papers, box 9., and "Ghana Government Drops Case Against Colvin," West Africa, September 28, 1957, 927.

353 "Ghana Government Drops Case Against Colvin," West Africa, September 28, 1957, 927.
} 
Nkrumah was stocking his government with. ${ }^{354}$ Thus, while Lewis' past work with both the U.N. and the British government encouraged them to believe he would be a "moderating influence in Ghana," upon his arrival they were quickly made aware of where his loyalties lay.

\section{Seeking the Economic Kingdom:}

While Lewis accepted his appointment as Nkrumah's Economic Advisor in May 1957, he was unavailable to begin working until October of that year, as he had been living in California where he had been a Fellow at the Center for Advanced Study in the Behavioral Sciences (CASBS) at Stanford University since 1956. Leaving Stanford in late July 1957 Lewis to make his way to Ghana, the demand for his expertise was placed on display. On his journey, he stopped in Mexico to deliver a lecture, traveled to a conference at the University College of Jamaica, and then to Trinidad to spend five weeks advising the Trinidad government, where his old friend from his student days in London, Dr. Eric Williams was serving as Chief Minister and leading an independence movement of his own.

Demonstrating the high demand in which Lewis' economic advice was regarded, Williams had offered Lewis to serve as his own Economic Advisor back in 1955, which Lewis most likely regrettably reject in order to complete his research projects at the time. ${ }^{355}$ After this Lewis, his wife and two daughters left Trinidad by ship for England. There the Ghana High Commissioner in London would arrange for Lewis to meet with

\footnotetext{
${ }^{354}$ No. 5, A. W. Snelling to Ian Maclennan, Office of the High Commission, October 17, 1951, PRO DO (Dominions Office), 35/9955, quoted in Tignor, Lewis and the Birth of Development Economics. (2006), 148.

${ }^{355}$ Lewis to Forbes Burnham, February 16, 1961., Lewis Papers, box 3.
} 
members of the Bank of England who had advised on the central bank that Ghana was establishing, officials of the Board of Trade working on the Common European Market, officials of the Cocoa Marketing Board, and anyone he felt it necessary to meet with. ${ }^{356}$ In these meetings, Lewis intended to make the acquaintance and ascertain the views of the people with whom he would be dealing with as he guided Ghana in its assertion of economic independence.

Arriving in Ghana on October 30, 1957, Lewis was prepared to use his expertise to place his Pan-African ideals in to practice. He was in full embrace of the nationalist cause of the nation, as Nkrumah and Ghana looked to Lewis to advise them on which aspects of the British system to retain, discard, and expand as he devised financial programs to harness Ghana's storied economic potential. In a welcome letter in 1957, Nkrumah expressed his pleasure and enthusiasm for Lewis' arrival and spelled out his intentions for his tenure as Economic Advisor. ${ }^{357}$ After initially surveying the country and a general stock-taking of Ghana's entire economic and financial policy, Nkrumah instructed Lewis to focus his attention on the 1958-59 Budget; the Volta River Project; Industrialization, particularly smaller industries; the construction of the new port at Tema and its new Township; and most importantly to construct a Five Year Development Plan to commence in June 1959.

In addition to these high priority programs, Nkrumah also requested that Lewis assists in resolving the problem of how revenue-earning Government Departments and Corporations could be made more profitable; serve on the Standing Development Committee, and most importantly to train two or three young economists that could carry

\footnotetext{
${ }^{356}$ Lewis to Betty Whitelaw, July 22, 1957, Lewis Papers, box 14.

${ }^{357}$ Kwame Nkrumah to Lewis, November 4, 1957, Lewis Papers, box 9.
} 
on the programs he initiated following his departure. What was clear was Nkrumah's aim to deploy Lewis' expertise in every capacity possible, as well as the high stakes riding not only on the success of the nation to make a strong entrance into the modern global economy but on himself. With the world's eyes gazing upon Ghana, Nkrumah laid his nation's economic and financial challenges upon Lewis, having visited Ghana four times and advised his government since 1952, was perhaps the most qualified individual for the task.

\section{Exposing Britain's Mismanagement of Ghana Investments}

In addition to the welcome letter from the Prime Minister, waiting on Lewis' desk in Ghana was a cautionary report issued by the World Bank, which corroborated the pessimistic views of the British Colonial Office regarding Ghana's economy. The report underscored that a "serious readjustment" was needed in Ghana's fiscal field as the ambitious goals of the ten-year plan resulted in rising recurrent expenditures that were now drawing on finds that had been earmarked for development to balance the ordinary budget. ${ }^{358}$ The report also noted that while nation reserves were still substantial, they were unlikely to remain so for long. In spite of these conditions, Lewis' concerns over Ghana's economic situation were quelled by the prospect of the nation approximately $£ 200$ million in sterling reserves, which he believed could be deployed to formulate a pragmatic five-year plan at the cost of $£ 100$ million "without blinking an eye-lid." 359

\footnotetext{
${ }^{358}$ IBRD, Central Files, Ghana, box 4, Technical assistance, quoted in Tignor, Lewis and the Birth of Development Economics. (2006), 151.

${ }^{359}$ Lewis to David Owen, Executive Chairman, Technical Assistance Board, United Nations, February 3 , 1958, Lewis Papers, box 10, folder 4.
} 
Ghana's Minister of Finance, K.A. Gbedemah, however, did not share Lewis' confidence in the nation's reserves.

Observing that the reserves had been invested in low-risk, long term, gildededged British securities, Gbedemah believed these securities would better serve Ghana's budget and development plans if they were liquidated and reinvested in commercial bonds that yielded larger returns. While Gbedemah was perhaps the most knowledgeable of Ghana's financial and economic matters at the time, he was hardly an expert as his highest level of education had been in secondary school. His position as Minister of Finance as a result of his involvement in Nkrumah's nationalist movement, in which he served as Vice Chairman of the C.P.P and ran the party's newspaper, the Accra Evening News. As a result, when the self-taught Gbedemah traveled to London in September 1957 to discuss his concerns with officials of the Bank of England, they swiftly dissuaded him from transferring the sterling reserves on the grounds that Ghana stood to lose heavily if the assets were sold at that moment. For the moment the experts at the Bank of England believed they had silenced the Minister; however, after reassessing the reserves Gbedemah found that the value of sterling reserves that had been invested and managed by the British Government's Crown Agents had 'been severely depressed by the recent rise in the United Kingdom Bank rate and the general lack of confidence in the pound sterling.

After informing Nkrumah, Gbedemah was sent back to London, this time with an expert of his own in Lewis. Reflecting the haste with which decisions were being made, Lewis “was given twenty-four hours' notice to accompany the Minister of Finance to London, on a mission the purpose of which was not announced until after we had left 
Ghana." ${ }^{360}$ While he had no prior knowledge of how Ghana's sterling reserves were invested, Lewis quickly recognized the Crown Agents' mismanaging of the funds. Ghana's reserves fell into three categories, two of which had been mishandled. The first category consisted of $£ 70$ million in sterling balances that Ghana had accumulated from its contributions to British efforts in World War II and from budgetary surpluses from the cocoa revenues in the post-war year. The second category of reserves was from the Cocoa Marketing Board, worth around $£ 40$ million, and the third totaling in $£ 41$ millions from the holdings of the Ghana Currency Board. It was discovered that the Crown Agents had mismanaged these funds and incurred substantial losses as the first category of sterling reserves had shrunk from $£ 70$ million to $£ 61$ million in 1957 , and the $£ 40$ million investment from the Cocoa Marketing Board had suffered a 25\% decline in value. Arriving in back London less than three weeks after his initial departure for Accra, Lewis was deeply critical of the Crown Agents' investment strategy. In the meeting, Lewis noted that while these funds had been channeled into long-term securities, that would indeed incur substantial losses if sold at the present time, it was discovered that Ghana had lost one-seventh of its original $£ 150$ million in reserves and surpluses. ${ }^{361}$ He expressed that these heavy losses of Ghana's surpluses had shaken the confidence of the Ghanaian government in the competence of Crown Agents' ability to safeguard Ghana's interests. In addition to this, it was discovered that of the over one thousand different funds managed by the Crown Agents, totaling nearly $£ 1,000$ million had depreciated as well. ${ }^{362}$ Upon his arrival in London, Lewis received a letter from a

\footnotetext{
${ }^{360}$ Lewis to Luker, December 12, 1957, Lewis Papers, box 9.

${ }^{361}$ Note by A. W. Snelling, November 27, 1957, PRO DO 35/9426 quoted in Tignor, Lewis and the Birth of Development Economics. (2006), 156.

362 Tignor, Lewis and the Birth of Development Economics. (2006), 157.
} 
colleague at the University of Manchester, informing him that the British newspaper, "Guardian" reported that these talks of the sterling reserves would be Lewis' first official act as Ghana's Economic Advisor. ${ }^{363}$ It was clear that his endeavors in Ghana were being observed not only by the British government and professional economists but also by academics and the general public.

Understanding the implications for the international standing of the British sterling if this embarrassing news of the failings of the Crown Agents were to become public, Lewis leveraged his and Gbedemah's knowledge of the situation to remove Ghana's funds from the Crown Agents and place them under a Ghanaian management team. Additionally, the Commercial Bank of Ghana was endowed with the authority to manage the nation's reserves and chose to no longer make investments through the Crown Agents. Subsequently, the Commercial Bank of Ghana along with Lewis oversaw the process of selling off the British securities and purchasing of other investments that would be available for liquidation when and as the Ghanaian government needed them.

Until this point, Ghana's surpluses, which their plans for economic development and industrialization rested, had been heavily invested in the British sterling, as it was championed as a steadfast currency; however, the losses suffered during World War II and the rise of the United States as the world's dominant economic power contributed to the sterling's decline in the post-war years. The Bank of England and the Commonwealth Relations Office were relieved that Nkrumah had "an advisor of such impeachable reputation and ability as Professor Lewis," and preferred his discretion to Gbedemah's

\footnotetext{
${ }^{363}$ Lewis to Mars, November 22, 1957, Lewis Papers, box 9.
} 
"wild ideas about what could and should be done" in response to the British Crown Agent's lack of stewardship. ${ }^{364}$

It was apparent that the British, in the post-war years, sought to sure up their own depleted economy using funds from their empire, and to later funnel resources back into the colonies. However, the British had not expected the push for decolonization, let alone independence, especially in Africa, to arrive so quickly. Consequently, the realizations from these meetings stripped away the elation of political independence that had overcome Ghana months prior. In fact, it reinvigorated Nkrumah and the Ghanaian government's drive to assert its economic independence, which now because of Lewis' expertise, had full control in the managing of its investments, and sought to free itself from the bounds of a supposedly rock-solid international currency by establishing a currency of its own.

\section{Lewis' Reception in Ghana:}

Lewis' endeavors in the reorganizing of Ghana's sterling balances, corroborated the legitimacy of his observations in his 1953 Report on Industrialization, that Ghana must reduce its dependence on cocoa for economic development. The gravity of his role as Economic Advisor to the first African nation to achieve independence set in as his first assignment required that he take on the Bank of England and expose the decline of the British sterling. It was more apparent to Lewis that his "usefulness here [Ghana] depends on my having the confidence of the prime minister" 365 While Nkrumah's trust in Lewis was apparent in the long list of tasks, projects, and policies that his advice was sought for,

\footnotetext{
${ }^{364}$ Note by J. Loynes, Bank of England, November 28, 1957, PRO DO 35/9426, and Note to Governor of Bank of England, November 27, 1957, BE C40/299, quoted in Tignor, Lewis and the Birth of Development Economics. (2006), 157.

${ }^{365}$ Lewis to Luker, December 12, 1957. Lewis Papers, box 9.
} 
including his last-minute mission to London to reorganize the sterling balances, Lewis was still a foreigner and an expatriate working in Ghana. Nkrumah's embrace of PanAfricanism for Ghana extended beyond a racialize imagined community standing in solidarity with each other. Rather, a fundamental principle for Ghana's government under Nkrumah was the practicing of Pan-Africanism in government. Although Ghana became the epicenter of Pan-African activity following independence, Nkrumah's Pan-African endeavors and recruiting of foreigners, including those from the African diaspora, were not supported everyone in Ghanaian society. This was exemplified best in the case of George Padmore, the Trinidadian who was serving as Nkrumah's Advisor on African Affairs and was regularly slandered in Ghanaian print media and scorned by Ghanaian politicians because of the power and influence he wielded. This was not the experience for Professor Lewis in his role as Economic Advisor.

Upon his return from the meetings with the Bank of England, Lewis was finally able to focus on the Ghanaian economy and along with this came his ingratiation into Ghanaian society. Early on Lewis' reception by Ghanaian society was, on the whole, positive experience as letters of support and requests for his presence were sent to this office. In a December 1957 letter from a Ghanaian nationalist, named J.B. Ferguson, Lewis was welcomed "to land you rightly can claim as your own." ${ }^{366}$ Several Ghanaians had been following Lewis' work since his Report on Industrialization in 1953 and agreed with this belief in a firm agricultural sector being the precursor to industrialization and economic development. While Lewis had been featured in Ghanaian newspapers since the early 1950s, others knew of him from his BBC interviews and were struck by his

${ }^{366}$ J.B. Ferguson to Lewis December 3, 1957 Lewis Papers, box 5. 
frank, sincere, and directness when discussing African sovereignty and the development in Africa. For many he was viewed as coming "to the aid of [his] people" and with his "efforts [to] be fruitful in the pursuit of economic and social redemption of the African and peoples of African descent." ${ }^{367}$ Lewis, fundamentally concerned with raising the standards of living of the people of underdeveloped nations, customarily honored these words of encouragement and support with a humble reply of: "I shall endeavor to do my best. ${ }^{368}$

In addition to this, the Ghanaian elites were eager to entertain Lewis at club meetings, dinners, and university programming. By the end of December 1957, Lewis had accepted an offer to serve as Vice President of the Ghana Geographical Association, surely not for his expertise in Geography, but rather for the high regard in which he was held and the notoriety it would bring to the organization. ${ }^{369}$ Lewis' presence was constantly being requested, as clubs and organizations competed for his attendance at their meetings. In one instance, Lewis regrettably declined dinner with the Cosmopolitan Dining Club because he had already committed to spending the same evening with the West African Cocoa Research Institute. ${ }^{370}$ Additionally, by 1958, he was serving as President of the Economic Society of Ghana. People normally sought to not only use these opportunities to speak with Lewis regarding the economic situation and challenges facing Ghana but also to establish a relationship with a government official free of ethnic ties and with direct access to the Prime Minister.

\footnotetext{
367 Ibid.

${ }^{368}$ Lewis to J.B. Ferguson December 16, 1957, Lewis Papers, box 5.

${ }^{369}$ Lewis to E.A. Boateng, December 19, 1957, Lewis Papers, box 3.

${ }^{370}$ Lewis to Mahtani, January 20, 1958, Lewis Papers, box 9.
} 
Lewis was also regularly invited to speak at the University College of Ghana, especially the Institute of Extra-Mural Studies, regarding his approach to economic development and industrialization. ${ }^{371} \mathrm{He}$ was also awarded an Honorary Fellowship to the Akuafo Hall of Excellence at the University College of Ghana in 1958. With a pristine record of Pan-African activism, working with the British Colonial Office and the United Nations, as well as being a highly respected economist in the British academy, Lewis distinguished himself from the radical Padmore and Makonnen, as he embodied the respectability and Victorian values that many British educated Ghanaian elites strove for.

Lewis' notoriety in Ghanaian society, along with the excitement for economic development was so widespread that the Ghana Broadcasting System featured New Year's Message from Lewis to be read to the nation. In his message, Lewis proclaimed that Ghana entered 1958 with confidence for the economic future, as work on the fiveyear development plan commencing. Lewis assured the Ghanaian public that the plan would include economic policies for industrialization, diversifying agriculture, roads, electricity, education, health and other social services. ${ }^{372}$ Encouraging the Ghanaian people to recommit themselves to their trades, and to seek further education and skills training, Lewis reiterated the development was not solely dependent on the government but also on what each individual does with their opportunities. Finally, he concluded his message with good wishes for the people to "find peace in your heart and prosperity in your pocket." ${ }^{373}$ In addition to his own message, Lewis advised Nkrumah on his

\footnotetext{
${ }^{371}$ Lewis to Kimble, July 5, 1958, Lewis Papers, box 8.

${ }^{372}$ Lewis, New Year Message, December 23, 1957, Lewis Papers, box 9, folder 7.

${ }^{373}$ Ibid.
} 
Christmas Message to the nation, in which Nkrumah declared the overall welfare the Ghanaian people, including the abolition of poverty, improving healthcare, education, water access, and electricity, as the measurements by which the government would be judged. ${ }^{374}$ The overlap in Lewis and Nkrumah's messages to the nations was apparent, as the Prime Minister and his Economic Advisor seemingly entered 1958 in agreement regarding the path forward. However, the year would prove to be the most difficult of their time together as Lewis formulated the 1958-1959 Budget and the nation's Five-Year Development Plan.

\section{Ghana’s 1958-1959 Budget}

Having rectified Ghana's sterling reserve balances and completing his surveys of Ghana's economic and financial policies, Lewis was now free to turn his attention to drafting the nation's budget for the coming year. Early on in the process, Lewis was optimistic about his plans for the budget, as reflected in his New Year's Message to the nation. Unfortunately, by January 1958, Lewis was forced to confront his growing frustrations with the Ghanaian government. In a letter to a fellow economist, Robert R. Nathan, Lewis admitted that while "We have been pretty well served in Ghana on the statistical side, including their preparation and analysis of economic statistics... We are not so well served on the economic side." 375

By this, Lewis meant that from an administrative and resources standpoint, what was needed was an "Economic Section, with about half a dozen professionals, doing work of which is now done in three or four other Ministries by non-professionals." 376

\footnotetext{
${ }^{374}$ Lewis to Powell, December 20, 1957., Lewis Papers, box 11.

${ }^{375}$ Lewis to Robert R. Nathan, January 18, 1958., Lewis Papers, box 10.

${ }^{376}$ Lewis to Owens, February 3, 1958, Lewis Papers, box 10, folder 4.
} 
Lewis even admitted that although it was not difficult to find professionals, Ghanaian and expatriate, who share the government's objectives for industrialization, the real challenge was to find half-a-dozen men who are competent to run $£ 4,000,000$ worth of state-owned industrial enterprises. ${ }^{377}$ In addition to this Lewis feared that many of the expatriates working in the Civil Servants were contemplating leaving Ghana, because of their own dissatisfaction with Ghanaian Ministers and the recent decision to postpone the start of development programs until 1959, which Lewis viewed as "a political mistake of the first order." ${ }^{378}$ In response to these fears, Lewis developed a plan to borrow technicians from the government of India, which had already been approved by the Indian Prime Minister, Jawaharlal Nehru.

Still, the primary purpose of Lewis' mission to Ghana was to create and implement an economic development plan for the nation; consequently, Lewis did not take the drafting of Ghana's budget lightly. A decade earlier, in July 1949 Lewis authored a pamphlet for the Fabian Society entitled The Principles of Economic Planning, in which he argued that "The budget is not the only instrument available for planning, but it is the most important, the most powerful, and the most embracing." 379 For Lewis, the national budget was the main instrument and the foundation of economic planning and in the case of Ghana, Lewis' budget prioritized industrial and agricultural development. ${ }^{380}$ In doing so he sought to address two roadblocks on Ghana's path to economic transformation: the increasing recurrent expenditures in place from the

\footnotetext{
${ }^{377}$ Lewis, Standing Development Committee: Report on The Industrial Development Corporation, April 1, 1958, 5, Lewis Papers, box 20 folder, 7.

${ }^{378}$ Lewis to Owens, February 3, 1958, Lewis Papers, box 10, folder 4.

${ }^{379}$ Lewis, The Principles of Economic Planning. (1949), 27.

${ }^{380}$ Ibid., 29.
} 
previous ten-year development plan and the now declining cocoa prices that were once thought to possess unprecedented potential and easily capable of funding Ghana's development projects. Early on Lewis struggled to get recurrent expenditures under control, as they had increased $60 \%$ in the past four years. Lewis feared that if they continued to rise at such a rate the nation would soon be bankrupt. As a result, his "cry [was] for less in the ordinary budge and more in the development budget. The second half of this cry" Lewis admitted was "more welcome than the first," as several government officials did not share Lewis's conservative approach to government spending. ${ }^{381}$

Lewis was "also concerned about the over-reliance on cocoa revenue," and hoped "to get a more balanced tax policy." ${ }^{382}$ His approach to development in Ghana consisted of what historian, Harcourt Fuller, referred to as "industrialization by invitation," which sought to diversify Ghana's agricultural sector and encourage industrialization by inviting public and private business firms to invest in Ghana's economy. ${ }^{383}$ As a result, the budget also proposed tax code incentives for attracting foreign capital. Critical to the budget was Lewis' reorganizing of the Industrial and Agricultural Development Corporations, which he believed were pivotal to aiding private firms in identifying profitable projects and providing start capital for local business. Reflecting the Ghanaian government's commitment to innovation, Lewis believed the Industrial and Agricultural Development Corporations to be the key to economic development as they would connect the interests of domestic and foreign private capital to those of the state. ${ }^{384}$

\footnotetext{
${ }^{381}$ Lewis to Henry Bloch, February 8, 1958, Lewis Papers, box 3.

${ }^{382}$ Lewis to Owens, February 3, 1958, Lewis Papers, box 10, folder 4.

${ }^{383}$ Harcourt Fuller. Building the Ghanaian Nation-State: Kwame Nkrumah's Symbolic Nationalism. (New York: Palgrave Macmillan, 2014), 55.

${ }^{384}$ Tignor, Lewis and the Birth of Development Economics. (2006), 160.
} 
Thus, while Lewis' reasoning and planning were sound from an economic standpoint, the budget failed to live up to his expectations, as the pressures of reconciling politics and sound economics quickly became apparent. In The Principles of Economic Growth, Lewis asserted that "Where corruption is rife in the Treasury, the budget is not powerful enough for planning." 385 Unfortunately, the corruption pulsing through the Ghanaian government soon became apparent to Lewis. After reorganizing the Industrial and Agricultural Development Corporations, Lewis placed both corporations under the direction of Ayeh Kumi, a successful businessman in Accra. While Lewis recommended Kumi for his strength of character as well as his experience as a skillful businessman, he soon gained the alias of "Mr. Ten Per Cent," as corruption was rampant throughout the Industrial Development Corporation (IDC). ${ }^{386}$ A key example is found in the Ghana Bottling Company, which many believed would have been a success had $75 \%$ of its profits been siphoned off to the CPP and the remaining $25 \%$ to the IDC.

In addition to this Lewis observed that the administrative machine was not running smoothly, as relations between Ghanaian Ministers and the expatriates working in the Civil Service had begun to deteriorate. He observed that Ministers had begun to circumvent the administrative process by formulating policy without consulting Lewis or the Civil Servants regarding administrative and technical issues. This often resulted in policies reaching the Cabinet before meeting Lewis' approval and even in one case, Lewis having to ask Nkrumah to stop a policy from being implemented after it had been passed by the Cabinet. ${ }^{387}$ Matters were made even worse as Ministers increasing took

\footnotetext{
${ }^{385}$ Lewis, The Principles of Economic Growth (1969), 27.

${ }^{386}$ Lewis, Standing Development Committee: Report on The Industrial Development Corporation, April 1, 1958, 5., Lewis Papers, box 20 Folder, 7.

${ }^{387}$ Lewis to Owens, February 3, 1958, Lewis Papers, box 10, folder 4.
} 
"on unqualified relatives" along with "constant interference from ministers and other politicians in the operations of particular projects." 388 These administrative woes caused Lewis a great deal of frustration as he contemplated his future plans for not only devising a plan for development but also implementing it. Furthermore, after the National Assembly adopted his budget proposals, Lewis was able to devote his attention solely to the new development plan, which would place the intertwined nature of economic policymaking, state-owned companies, and political patronage on full display.

\section{Preparing Ghana's Second Development Plan}

Ghana's Second Development Plan was the most important assignment that Nkrumah would task Lewis with completing during his time in Ghana. Lewis was recruited to work in Ghana for his expertise in development economics and his extensive work and research on economic planning. Lewis' primary objective in preparing the development plan was to promote fiscal realism among the Ghanaian politicians so that an affordable plan could be drafted and executed in a timely fashion with immediate economic gains. Such a plan, in Lewis' opinion, would not exceed $£ 70$ to $£ 80$ million or $£ 15$ million a year for five years and was easily within the fiscal capabilities of the nation. Understanding that Nkrumah would desire as much to be included in the plan as possible, Lewis believed that launching a $£ 100$ million plan was still pragmatic and would have a great advantage of restoring purpose and direction to the government in matters of economic development. ${ }^{389}$ Conversely, while Lewis advised Nkrumah and his Ministers on the putting forth a cost-effective plan, that would draw on foreign capital

\footnotetext{
${ }^{388}$ Tignor, Lewis and the Birth of Development Economics. (2006), 160.

${ }^{389}$ Lewis to Owens, February 3, 1958, Lewis Papers, box 10, folder 4.
} 
and avoided draining the cocoa surpluses, in May 1958 the ministers prepared departmental requests and proposals for a plan with allocations totaling $£ 185$ million. Lewis' recommendations for a conservative and affordable plan had fallen on deaf ears, as Ghanaian politicians, including Nkrumah, seemed uninterested in exercising fiscal restraint in their proposals for the plan.

Ministers and government officials viewed the plan as a vehicle for their own pet schemes and some even began signing contracts for programs before they were even approved by Lewis and the development committee for the final draft of the plan. By July 1958 , Nkrumah released a memo to his cabinet that allocations totaling $£ 277,804,000$ represented the framework of an impressive Second Development Plan, which he wished to see put forward for implementation over a five-year period beginning July $1959 .{ }^{390}$ Maintaining the necessity of making cuts to the swelling costs of the plan, it seemed that Lewis represented the sole voice of reason as Nkrumah's desire for rapid results and extravagance went airy. In response to Lewis' insistence on reductions to certain programs in the plan, Nkrumah was clear that priority should be given to Industry and Electricity, Defence, Health, Agriculture, Tourism, and the Floating Dock, in that order. ${ }^{391}$ His favoring of Industry and Electricity come as no shock, as industrialization and the VRP had been the basis of economic development planning in the nation since the late 1940s. However, the priority given to allocating funds to the nation's defense (Army, Navy, Air Force, and Territorial Force) speaks to Nkrumah's vision for placing Ghana on the international stage not only as an economically modern nation but also as a military power as well.

\footnotetext{
${ }^{390}$ Minutes of A Meeting of the Cabinet, July 11, 1958, 1. Lewis Papers, box 21 folder, 7. 391 Ibid.
} 
Still, Lewis and Nkrumah's priorities for the plan bore a stark difference in that Lewis sought to prioritize Agriculture and Industry, Electric power, Secondary education, Rural water supplies, and Public Health. ${ }^{392}$ For Lewis, Agriculture and industry, as they had since in 1953 Report constituted the most important priorities beyond all other because they were the keys to economic development, which was needed to support everything else. He noted that "the first development plan must be written off as a failure," as the nation spent $£ 93$ million on development between 1950 and $1957 .{ }^{393}$ And while there were substantial improvements in road networks, electricity supplies, doubled the number of children in primary schools, and reduced unemployment, the money place into circulation did very little to increase basic production, as imports increased by $80 \%$, including a doubling of food imports. As a result, what concerned Lewis more so than the prioritizing of allocation to certain programs was that, although Nkrumah claimed the emphasis of the plan was to be economic development, only £79 million had been set aside for non-economic schemes. For Lewis, the duel sector model was still the basis of economic development. Thus, to achieve an increase in agricultural and industrial output, Lewis acknowledged that they must spend less on everything else than was spent in the first plan.

This meant that the allocations for the non-economic schemes or "prestige" projects of Nkrumah and the Ministers needed to be drastically reduced. For Lewis, many of these prestige projects contributed neither to production nor to the people's welfare. Among them were the international conference hall costing $£ 1,000,000$, a navy, air force,

\footnotetext{
392 Lewis, The Second Development Plan: Note on the Size of the Programme, June 26, 1958, 3., Lewis Papers, box 21 folder, 7.

${ }^{393}$ Lewis, Note on the Size of the Programme, June 26, 1958, 3, Lewis Papers, box 21 folder, 7.
} 
external broadcasting, and medical school costing $£ 3,000,000$, and $£ 650,000$ a year, an elaborate University architecture, a large floating dock costing $£ 1,500,000$, airlines, shipping lines, palaces for Regional Commissioners and innumerable embassies. ${ }^{394}$ To tax the people of Ghana for "such frills," Lewis believed, was to impoverish them. Furthermore, he suggested that such extravagance would damage Ghana's prestige abroad, giving the impression that Africans don't know the value of money and are incapable of making sensible judgments.

Perhaps the largest prestige project being forced into the second development plan was Nkrumah's magnum opus, the Volta River Project, which featured the government's major hydroelectric dam. The Akosombo Dam was the largest single infrastructure of its time and was intended to provide electricity not only to the entire nation but eventually all of West Africa according to Nkrumah's plans. The dam would also provide cheap electricity for aluminum smelting project, which was intended to use Ghana's rich bauxite deposits to export aluminum and decrease the nation's dependence on cocoa. The construction of the Akosombo dam was also expected to create the largest man-made lake in history. This lake was intended to facilitate the creation of a transport system linking southern to northern Ghana, supply water for agriculture, and to expand the nation's fishing industry. ${ }^{395}$ Nkrumah believed the VRP was the nation's key to economic development and national prosperity; however, in Lewis' opinion, Ghana simply could not afford the project.

\footnotetext{
394 Ibid., 4.

395 Dan-Bright S. Dzorgbo. Ghana in Search of Development: The Challenge of Governance, Economic Management and Institution Building. (London: Routledge, 2017), 153.
} 
Negotiations and planning for the VRP had been taking place since the 1940s, as the British believed the electricity and the aluminum produced by the dam would greatly benefit their empire as it recovered from the second World War. Following Nkrumah's election in 1951, he immediately reached out to Lewis for his advice through their mutual friend, George Padmore on how the project could be financed. Always skeptical of colonial government's, the British enthusiasm and eagerness to provide loans for the VRP, to Padmore, seemed to be nothing more than a ploy for them to maintain control over Ghana after independence. Lewis' view on the VRP in 1958 was the same as it was in 1952, which was that Ghana's lack of investment capital and technical expertise could not be overcome without foreign capital. ${ }^{396}$

As he prepared the second development plan, Lewis believed the development of the country to be more important than the Volta River Project, which he "consider to be of only marginal significance" and entirely too expensive for the current plan. Lewis observed that relying on the Volta Dam as the single power source to electrify the entire country was not a practical proposition from a financial standpoint. Ghana could not afford to do so since electricity would be sent out from the dam into the grid, and then to transformers throughout the country to tap the grip for power. Furthermore, these transformers and other equipment would cost $\$ 150,000$ for each site where the grid would be tapped. Lewis thought it wiser to install diesel generators for $\$ 10,000$ to $\$ 50,000$ rather than spend $\$ 150,000$ to tap the grid. ${ }^{397}$

Still, he believed that even if a Volta dam was built, most of the country would still have to rely on individual generators for electric current, and apart from the VRP's

\footnotetext{
${ }^{396}$ Lewis to Padmore, April 16, 1952., Lewis Papers, box 10, folder 6.

${ }^{397}$ Lewis, Note on the Size of the Programme, June 26, 1958, 2., Lewis Papers, box 21 Folder, 7.
} 
aluminum industry, electric power from the Volta dam is virtually irrelevant to the general electrification of Ghana. Lewis believed that if the VRP were to materialize then the Second development plan would need to be cut by another $£ 25$ million. Lewis and others developing the project for the past decade had always believed that funding for the dam would come from foreign capital. Furthermore, spending all the money Ghana had on the VRP would surely exhaust the nation's borrowing powers in the future and according to Lewis, be the end of all other development in Ghana for the next ten years. ${ }^{398}$

Lewis was aware that foreign companies were eager to invest in Ghana; however, he believed the irresponsible spending being proposed for the development plan would ultimately impede Nkrumah's objective to secure economic stability in Ghana and the liberation of the rest of the continent from colonial and foreign domination. In his opinion, Ghana could not afford to spend more than $£ 100$ million in the next five years and should not try to do so. Lewis worried that such an expensive second development plan would use up Ghana's reserves and borrowing capacity in its five-year run time, leaving nothing for the third development plan. He recognized that virtually no development occurred in Ghana between the 1930s and 1958; however, he warned Nkrumah and his cabinet that the temptation to bring about all of the development that should have occurred during the past thirty years in such a short period of time must be resisted. Because of this Lewis believed that the plan should include programs that address the present needs of the people and while some programs could be excellent and

\footnotetext{
${ }^{398}$ Ibid.
} 
were badly needed by the people, they could be postponed until the Third Development Plan.

In a note to Nkrumah and his cabinet regarding the current state of the development plan, Lewis declared that "This is not a development plan, but merely a wish list." ${ }^{399}$ For Lewis planning was the basis of economic development. As such, he maintained that "planning consisted of cutting one's coat according to one's cloth," and that "If ministers merely draw up a wish list of what they would like to buy, irrespective of what is possible, they must not call it a plan." ${ }^{" 400}$ Moving forward the viable plan, Lewis believed, was to cut non-economic schemes down to an allocation of $£ 40$ million. Doing so must not be difficult if each program considered for removal were subject to three criteria: (1) it did not contribute to the welfare and security of the people; (b) it did not require a department receiving a larger allocation than it can reasonably spend, and (c) it was being funded merely because credit was readily available.

It was clear to Lewis at this point that the government had not yet decided whether it was "merely drawing up a list for propaganda purposes, or if it is really making a plan, that is, deciding seriously what to do with its limited resources. Making a list of things we would like to have is not planning, and so far this is all that has been done." 401 In spite of this neither Nkrumah nor the Ministers were willing to abate the magnitude of their proposals and continued to pressure Lewis as he prepared the plan. As a compromise, Lewis chose to divide the plan into two phases, the first consisting of high priority programs that surely be achieved in five years, and a second, which Lewis

\footnotetext{
${ }^{399}$ Lewis, The Second Development Plan: Note by the Economic Advisor, July 7, 1958, 1., Lewis Papers, box 21 folder, 7 .

${ }^{400}$ Ibid.

${ }^{401}$ Ibid., 2.
} 
labeled as a "wish list," consisting of programs to be implemented if money and time remained..$^{402}$

This however did not quell the ever-increasing tensions between Lewis and Nkrumah, who had now been in dispute for months regarding the "spending spree" that Nkrumah and the Ministers had embarked on, as Lewis attempted to pare back their prestige projects. As such, an inescapable moment arrived in August 1958, when Lewis penned a letter to Nkrumah formally expressing his frustrations stating that the plan "as it now stands is awful. It makes inadequate provision for some essential services while according the highest priority to a number of second importance." ${ }^{303}$ Lewis was clear regarding the cause of the current state of the plan, attributing its lack of balance to its "many schemes on which the Prime Minister is insisting for "political" reasons... a whole packet of schemes, none of which develops the country or adds to the people's welfare."

In addition to this Lewis included an $£ 18$ million “special list” of Nkrumah’s pet projects including a floating dock, new airports in all regions of the nation, an international conference house, a yacht for V.I.P.s, a royal palace, external broadcasting, new embassies, and a new medical school. Lewis then reminded Nkrumah that in order to give him "these toys," he and the Development Commission had to cut down severely on water supplies, health centers, technical schools, roads, broadcast rediffusion, irrigation, the Agricultural Development Corporation, telephones, housing and other services which the common people need so badly. He also reiterated that the heavy

\footnotetext{
${ }^{402}$ Cabinet Agenda, Second Development Plan, July 8, 1958, GNA ADM 13/2/40. quoted in Tignor, Lewis and the Birth of Development Economics. (2006), 162.

${ }^{403}$ Lewis to Nkrumah, August 1, 1958, Lewis Papers, box 10.
} 
recurrent expenditure of these pet projects would only be met by additional taxes that would "effectively impoverish the people."404

In his final plea, Lewis begged Nkrumah to reconsider his advice. First, he reminded Nkrumah that the common people of Ghana loved and trusted in his decision whether it was an international conference hall or water supplies. This Lewis believed gave Nkrumah duty to allocate funds not to projects for swank or politics until their essential needs had been cared for. Next Lewis begged Nkrumah “on behalf of black people everywhere" to consider that white people have always said that people of African descent did not know how to spend money. ${ }^{405}$ Furthermore, he reiterated that the current plan made not just Ghana but the entire race look ridiculous for "spending on showing off, instead of on essentials," and that Africans in every content looked to him and Ghana to prove them wrong.

Finally, Lewis pled "as a socialist" that while the people still had no water nor access to healthcare, spending money on embassies, air forces, yachts, and other such boastfulness was “downright sinful." From the outset of his career as an economist, Lewis' concern had been for using development economics as a vehicle for raising the standard of living of the ordinary of lesser-developed nations and Lewis' committed to these principles were on display. His words, however, had no effect on Nkrumah and by November 1958 the cost of the development plan had swelled to over $£ 200$ million, with at least $50 \%$ of the total expected to be financed by the Ghanaian government. What was clear at this point was that Nkrumah viewed the plan and his prestige projects through a

\footnotetext{
404 Ibid.
}

405 Ibid. 
political lens, as demonstrations of the CPP's power and security, as well as an assertion of the political stability of his regime.

By December 1958, Lewis had taken nearly as much as he could stand, as Nkrumah had "messed up the Development Plan" with his lavish spending on unnecessary projects (International conference halls, airlines, floating docks, and large embassies abroad etc.) making it "one of the worst plans ever published." With Nkrumah now rarely seeking or heeding his advice, Lewis was now tired of playing nursemaid to grown men, but also growing weary of the political atmosphere, which he described as a "fascist state [that was] in full process of creation." ${ }^{406}$ Lewis was no doubt referring to the new legislation prohibiting strikes and thus neutralizing trade unions, as well as the Preventive Detention Act passed in July 1958 that provided Nkrumah with power to deem individuals threats to the state and have them arrested for up to five years without trial.

Expressing his frustrations to his close friend Hugh Keenleyside, director-general of the Technical Assistance Administration at the United Nations, it was clear that Lewis' time in Ghana had run its course. However, Lewis preferred to avoid making his departure a public issue for enemies of Africa to seize upon. Furthermore, while it was common knowledge that Lewis had accepted a position as a professor of Economics at the University College of the West Indies starting in October 1959, Keenleyside provided Lewis with cover for his departure by offering him the position of Deputy Director of the United Nations' Special Fund for Economic Development. Still, Lewis reached out one more time to Nkrumah in a letter written on December 18, 1958.

${ }^{406}$ Lewis to Keenleyside, December 11, 1958, Lewis Papers, box 8. 
In the letter Lewis he disclosed to Nkrumah that having reconstructed Ghana's economic policies and institutions, completed the budget, and the second development plan, he had completed most of what he had set out to accomplish in Ghana. ${ }^{407} \mathrm{He}$ also deluged that the U.N. had offered him a position that was not only an honor to Africa but also placed him in a position of influence to look after Africa's interests. Lewis admitted that since submitting the first draft of the development plan in June of that year, his advice had been ignored and had he achieved nothing to justify staying in Ghana "if the next six months are to be like the last six months." ${ }^{408}$ He was still; however, willing to stay on in Ghana if Nkrumah agreed to three propositions: (1) Lewis would be sent for and present whenever the Cabinet was discussing the nation's economic policies; (2) the government would not invest more than $£ 25$ million of its own money in the Volta River Dam; and (3) the first phase of the second development plan would not exceed $£ 120$ million.

Lewis declared that he would be delighted to stay and continue to serve in every way he could if Nkrumah accepted these conditions, but if they could not agree on these fundamentals he believed it best that he should take accept the U.N.'s offer and "try to help the poor countries of the world to build up their productive capacities." ${ }^{\circ 409}$ In a brief response Nkrumah acknowledged that the offer from the United Nations was extremely important and that with respect for his international standing as an economist, he could not expect Lewis to risk his reputation for political decisions he felt he must make. Admitting that Lewis' advice and his own decision were likely to run counter to each

\footnotetext{
${ }^{407}$ Lewis to Nkrumah, December 18, 1958, Lewis Papers, box 10.

408 Ibid.

${ }^{409}$ Ibid.
} 
other, Nkrumah expressed, with regret, that it would be best for Lewis to accept the United Nations' appointment so that the two may part in a friendly manner and not on an issue that would embarrass them. ${ }^{410}$

\section{Gradualism or Rapid Development?}

Nkrumah's parting words to Lewis were demonstrative of the clash of personalities that took place between the two for the duration of Lewis' tenure in Ghana. In his letter, Nkrumah admitted that while the advice Lewis had given him was sound, it was essentially from an economic point of view and that as a politician he must gamble on the future. ${ }^{411}$ This statement by Nkrumah is key to understanding the nature of the relationship between these two men. For Nkrumah, it was up to political leadership to set economic agendas and the role of economists was to design the programs to achieve the goals of politicians. On the other hand, Lewis believed that economics determined what could be achieved and outline the proper methods for attaining economic goals desired by politicians.

This fundamental difference is what caused the major rift between the two. Whereas Lewis lamented that Nkrumah viewed economists as mere technicians tasked to carry out economic dreams of politicians no matter how unrealistic the demands, Nkrumah complained that Lewis and economists, in general, were politically naïve, with very little understanding of the demands of ruling and the pressures from the political elites in a post-colonial nation. The primary disconnect was that Nkrumah as a leader of a nation and a ruling political party, politics required bipartisan coalitions, strategizing

\footnotetext{
${ }^{410}$ Nkrumah to Lewis, December 19, 1958, Lewis Papers, box 10.

${ }^{411}$ Ibid.
} 
against the opposition, and responding effectively to the high hopes and expectations of the people that had worked so hard for independence. ${ }^{412}$

While Nkrumah believed Lewis and his economic advice to be politically inept, he failed to grasp the political benefits of Lewis' approach to development. Since 1952, Lewis maintained, especially concerning Ghana, that industrialization was dependent upon agricultural improvement; it is not profitable to produce a growing volume of manufactures unless agricultural production is growing simultaneously. ${ }^{413}$ Furthermore, while Lewis and Nkrumah disagreed some they were in complete agreement regarding the state's use of cocoa surplus to develop industry, education, health care, and urbanization. To do this Lewis sought to capitalize on the high cocoa prices on the world market by freezing prices in Ghana at eighty shillings per sixty-pound load. In doing so Ghana's Cocoa Marketing Board would direct a larger amount of profits from the international sales to development projects. The result was a precarious political situation for the government, as the nation's farmers were not directly benefiting from booming international cocoa sales and they were essentially financing the nation's development, which was largely confined to the southern region ${ }^{414}$

Since 1954, the National Liberation Movement, which represented the political interests of the region that produced the majority of the country's cocoa and of its timber and gold for export, had presented the largest resistance to Nkrumah and the CPP government. Nkrumah and Lewis agreed these funds should be used for developing the nation as a whole; however, as demonstrated with the preparation of the second

\footnotetext{
${ }^{412}$ Tignor, Lewis and the Birth of Development Economics. (2006), 174

${ }^{413}$ Lewis, "Unlimited Supplies of Labour," (1954), 171-76.

${ }^{414}$ Fuller. Building the Ghanaian Nation-State. (2014), 64.
} 
development plan, they differed on which programs should be prioritized. While Nkrumah, seized on the moment to use the cocoa surpluses for extravagant programs in Accra that demonstrated the C.P.P's political power, Lewis thought it best to invest in the agricultural sector to optimize food production and the cultivation of cocoa. Lewis' approach would have centralized the success of cocoa producers and farmers to the development of the entire nation, NLM's main constituents, and made for a more holistic development plan. Such a plan would have spread investments evenly throughout the nation to address the needs of the ordinary people, as opposed to concentrating allocations to the pet projects of politicians in Accra. Had Nkrumah heeded Lewis's advice, instead of allocating funds to non-economic programs, perhaps the ethnic and regional division consuming Ghanaian politics may have been mitigated?

Beyond the issue of how to distribute funds derived from the cocoa industry, Nkrumah's desire to concentrate development in Accra revealed another issue in his vision for how Ghana would be presented to the world. Reflecting on an exchange between himself and Nkrumah, Lewis recalled that when a draft of Ghana's Development Plan was completed, Nkrumah informed Lewis that he planned to allocate $50 \%$ of the budget to the nation's capital, Accra, which had a mere $5 \%$ of Ghana's population. Nkrumah justified the decision arguing, "Why not? When you think of England, you think of London; when you think of France you think of Paris; when you think of Russia, you think of Moscow." In response, Lewis replied, "No, sir. When I think of England, I do not think of London because I live in Manchester, and this is also why I know that capital cities exploit the rest of the country"415 Here Nkrumah's emphasis on developing

${ }^{415}$ W. Arthur Lewis. "Unemployment in Developing Countries.” The World Today 23, no. 1 (1967), 16. 
Accra more so than any other part of the nation reflected not only the capital city's need for improved infrastructure but also Nkrumah's own frame of reference for what a modern nation looked like. The conference centers, large militaries, embassies, airlines, and royal palaces for himself and his ministers were all signifiers of modernity for Nkrumah, and following independence vision of development required that they are acquired in the shortest time possible.

Nkrumah accepted some of Lewis's advice; however, his gradual approach to industrialization was always a point of contention for the two, as rapid industrialism was his ultimate objective following independence. ${ }^{416}$ He was also driven by Economic Nationalism, which was the belief that politics drove the economy and that the outside world would always be hostile. ${ }^{417}$ This economic nationalism was influenced heavily by Nkrumah's Pan-Africanism, as he conceived of Ghana's independence as a prelude to the total liberation of the African continent from colonial rule. As such, rapid development in Ghana was meant to serve as a testament to the tangible achievements, results, and capabilities of the post-independence Nkrumah regime.

An indicator of this was the emerging competition for influence in West Africa with Guinea also touting a united Pan-African continent, and with Egypt who had recently constructed its own electro hydronic dam as well. Part of Nkrumah's PanAfrican programs included the construction of the African Affairs Center, student exchange programs with other African nations, a $\$ 10$ million loan to Guinea after gaining their independence and sending monetary aid to African revolutionaries across the

\footnotetext{
${ }^{416}$ Wole Soyinka. An Economic History of Ghana: Reflections on A Half-Century of Challenges \& Progress. (Ayebia Clarke Pub Limited, 2008), 55.

${ }^{417}$ Dzorgbo. Ghana in Search of Development. (2017), 149.
} 
continent. Consequently, rapid development was also meant to bolster Nkrumah's PanAfrica objectives for the African unit. This ultimately placed additional pressure on Lewis to take on the expensive prestige projects in the second development plan, as opposed to the third, to accelerate the pace of development to justify Ghana's leading role in Africa. Still, even after hearing Lewis' advice, as sound and fiscally responsible as it may have been, Nkrumah declared that as a politician he must gamble on the future and that "We shall be justified in taking calculated risks in this matter."

\section{Lewis the Reasonable Radical}

For Nkrumah everything that Ghana had fought for and gained with independence hinged on industrialism, lessening the dependence on Britain and foreign markets, and placing Ghana on par with the developed nations of the world. However, Lewis' approach of pragmatic and gradual development through optimizing agriculture for industrialization, stood in direct opposition to the rapid and extravagance of Nkrumah, as Lewis emphasized economic development through investing in infrastructure and agriculture to help spur industrialization. Unfortunately, Nkrumah's gambles did not pay off as the second development plan as its final draft carried a price tag of $£ 343$ million, with priority items budgeted at $£ 126$ million, another $£ 104$ million for phase 2 items, and $£ 103$ million set aside for the Volta River Project. To secure foreign capital, the government removed all control over the investment of funds and permitted firms to remit all profits. As a result, Ghana contracted $£ 124$ billion in financial commitments within six months of publishing the plan.

\footnotetext{
${ }^{418}$ Nkrumah to Lewis, December 19, 1958, Lewis Papers, box 10; and Cabinet Agenda, Second Development Plan, July 8, 1958, GNA/ADM/13/2/40. quoted in Tignor, Lewis and the Birth of Development Economics. (2006), 162.
} 
Nkrumah declared publicly that the plan would "give us a solid foundation to build the welfare state" and "give us a standard of living which will abolish disease, poverty, and illiteracy, give our people ample food, and good housing, and let us advance as a nation." ${ }^{19}$ However, in private Nkrumah feared the huge financial obligations it had taken on would quickly drain the nation's reserves. As such, after only two years into the second plan, Ghanaian officials concluded that the government had gone on "a spending spree, with no true sense of priorities, with the result that it had depleted its resources." 420

Although Lewis departed Ghana before the plan was published it was still recognized as his handiwork. While he had envisioned a plan stressing "rapid development under a flexible program in an open and free economy, with much emphasis on agriculture and the setting up of manufacturing industry." ${ }^{421}$ However, economists and experts aboard labeled the plan as "overambitious and unrealistic," noting it was clear that the plan was "intended to impress neighboring states rather than to represent a reality likely to be achieved in five years." 422 In the British press, the plan was deemed "singularly fruitless." Lewis' initial fears, expressed in his August 1958 letter to Nkrumah, had been realized as the press seized on the failures of the second development plan to allege a predisposition amongst Africans to corruption and overspending on prestige projects. Furthermore, while Lewis could have easily divulged the fiscal

\footnotetext{
${ }^{419}$ Ghana, National Assembly, Debates, March 4, 1959, 189ff. quoted in Tignor, Lewis and the Birth of Development Economics. (2006), 164.

${ }^{420}$ Record of Conversation with Robert Jackson at the Commonwealth Relations Office, May 26, 1960 PRO DO 35/9404 quoted in Tignor, Lewis and the Birth of Development Economics. (2006), 164.

${ }^{421}$ IMC Consultations with Ghana, Meeting no. November 4, 1958, International Monetary Fund Archives, C/Ghana/420.1. quoted in Tignor, Lewis and the Birth of Development Economics. (2006), 163.

${ }^{422}$ Note by R.B. Forman, CRO, March 12, 1959, PRO DO 35/9303, and Note by B.J. Green, CRO, February 2, 1960, PRO DO 35/9303. quoted in Tignor, Lewis and the Birth of Development Economics. (2006), 15.
} 
irresponsibility of Nkrumah and his ministers, he instead defended his year in Ghana, calling it "one of extraordinary success" and listing his accomplishments including reorganizing the Industrial and Agricultural Corporations, creating new machinery for making economic decisions at the cabinet and civil service levels, and several new policies enacted for agricultural education industrial development, foreign investment in agriculture, house, forest regeneration, expanding secondary education, and for managing the government's securities. ${ }^{423}$

Lewis also asserted that he had left Ghana simply because he has completed his mission and made sure to refer to Nkrumah and the Ghanaian government in high regard when publicly discussing the matter in its immediate aftermath. Conversely, in private Lewis insisted that the development plan in Ghana "looked fairly good until the politicians got hold of it and added $£ 40$ million of prestige projects;" however, this letter was written weeks before the final draft of the development plan was announced revealing that the Ghanaian ministers had added an additional $£ 100$ million to the plan. ${ }^{424}$ Additionally, Lewis repeatedly expressed his concern that in Nkrumah and his ministers' haste to promote his big and showy prestige projects, the Ghanaian government ran the risk of falling in the trap of failing to drive hard bargains as foreign capital poured in.

Politics, however, trumped economics for Nkrumah regarding the second development plan, as his attraction to large scale projects (like the VRP) and their price tags were spurred by his desire to demonstrate the symbolic strength of Ghana not only to the western world gazing upon their progress but also to the African continent. ${ }^{425}$ It was

\footnotetext{
${ }^{423}$ Lewis to Melvin Lasky, Editor of the "Encounter", March 26, 1959., Lewis Papers, box 8.

${ }^{424}$ Lewis to Loynes February 13, 1959. Lewis Papers, box 9.

${ }^{425}$ Lewis to Keenleyside, December 11, 1958, Lewis Papers, box 8.
} 
for this reason that, Lewis, a lifelong Pan-Africanist refused to make a public issue of his departure from Ghana, to avoid comforting the enemies of Africa everywhere. Understanding the magnitude of Ghana's position as the first African nation to gain independence, Lewis also realized that a public dispute with Nkrumah would not only expose his corruption, reckless decisions, and turn towards despotism, which could potentially slow independence talks for the rest of the continent as well as the colonies in the West Indies.

When Lewis left Ghana his planning and programs, based on a mixed economy, were soon replaced by an economic approach that emphasized full-scale state control and was skeptical of the free market. These changes were sparked by several things. First, the radical left-wing of the $\mathrm{CPP}$, now coming to prominence as Ghana's civil service became increasingly Africanized, that had succeeded in its push for a state-driven economic development strategy that mirrored the model of the Soviet Union. Additionally, this "lurch to the left" was aided by the failures of the second development plan; the increase of Soviet economic experts recruited to work in Ghana and Nkrumah's further consolidation of power with himself and the state.

Such a shift should come as no surprise as Nkrumah had been a longtime communist; however, the largest factor in this shift was the untimely death of Nkrumah's closest advisor George Padmore, who had maintained a skeptical disposition towards communism and the Soviet Union since the1930s. It was Padmore who had been training the young radicals in the CPP and advising Nkrumah that had kept the Soviet influence at bay. Upon news of his death, Nkrumah once again contacted Lewis to return to give the eulogy at Padmore's funeral. Having been a friend of Padmore's for more than 
twenty-five years Lewis accepted. In his speech, Lewis stated: "To George, as to nationalists everywhere, the independence of Ghana was a tremendous emotional release. We all rejoiced, and were anxious to serve." ${ }^{\prime 26}$ Lewis recalled the allure of witnessing the first African state to attain independence, and why he quickly leaped at the prospect of contributing to Ghana's nation-building process.

In Ghana, Lewis fully comprehended the gravity of the situation facing the new nation and took special care in assesses the economic situation to craft a sound plan for developing the nation. Lewis' expertise had been recognized since the early 1950s when Nkrumah contacted him produce a report on Industrialization for the nation. During his time as economic advisor he more than proved to worth the nation, particularly in his exposing of Britain's mismanagement of Ghana's sterling reserves and investments, which he was able to parlay into the ensuring the Commercial Bank of Ghana's authority to manage the nation's reserves and investments, and to establish a national currency of its own.

Consequently, the legitimacy and significance of Lewis' contributions must be measured by the soundness of the advice and economic planning that he delivered, rather than by Nkrumah's propensity to heed Lewis' counsel. As Lewis' economic advice was increasingly ignored by the Prime Minister and his ministers, who sought to enrich themselves with their prestige projects, Lewis could not remain in Ghana as Nkrumah and his ministers concentrated power amongst themselves and neglected the welfare of the people. ${ }^{427}$ These conditions would persist as Nkrumah's regime entered the phase of

\footnotetext{
${ }^{426}$ W. Arthur Lewis, "Tribute to George Padmore," Lewis Papers, box 5, folder 4.

${ }^{427}$ Lewis to John D. Esseks, Department of Political Science, Wisconsin State University, March 7, 1968, Lewis Papers, box 4. quoted in Tignor, Lewis and the Birth of Development Economics. (2006), 175.
} 
his benevolent dictatorship, in which the economic policies of the Lewis era were altered and eventually replaced with the socialist economic planning and the undemocratic governance that would bring about Nkrumah's removal from office. 


\section{T. RAS MAKONNEN AND PRACTICAL PAN-AFRICAN IN GHANA}

Implementing Nkrumah's Pan-African policies was no simple task and to do so the Ghanaian Prime Minister called upon the most seasoned members of the old guard from the Pan-African Movement to assist him. Among the Pan-African activists called to action in Ghana was T. Ras Makonnen from British Guiana. Makonnen brought with him a diverse skillset that was used broadly throughout Ghanaian society from building Pan-African institutions like the African Affairs Centre, African Affairs Committee, to advising on foreign policy with the Bureau of African Affairs, to managing state owned corporations, like State Bakeries, Ghana Hotels and Tourism Corporation, and the Guinea Press. During his time working in Ghana, Makonnen was also able to develop a unique analysis of Ghanaian society, as his work enabled him to observe not only the euphoria of Ghana's independence celebrations, but also the persistence of Ghanaian chauvinism amongst government officials, the implications of Nkrumah's attempts to implement socialism, and his nascent turn to authoritarianism. Through an examination of these themes, this chapter argues that Ras Makonnen proved vital to Ghana as he placed his Pan-Africanism into practice through state institution building.

Pan-Africanism From Within:

T. Ras Makonnen was born George Thomas Nathaniel Griffith in Buxton Guyana at the beginning of the twentieth century. He was the grandson of an Ethiopian miner 
that migrated to Guyana to capitalize on the nation's booming diamond and gold industry. Makonnen's father took advantage of the boom and became a concessionaire, establishing shops along the Mazaruni River to sell provisions to prospectors traveling up the river. Through his own business ventures and partnerships, he eventually came to own The King George Hotel in Guyana's capital, Georgetown. The young Makonnen closely observed and picked up his business acumen from his father.

He also began reading Marcus Garvey's Negro World newspaper and the NAACP's Crisis magazine, which provided him with a sense of Pan-Africanism and a political education beyond that of the British colonial system. Garvey's ability to incite Black consciousness and connect the shared histories and conditions of millions of Blacks in the African Diaspora was especially appealing to Makonnen in British Guiana's multi-racial society. As a result, at a young age, Makonnen understood the necessity of self-determination, Black economic empowerment, and the power of print media in international Black politics. All of these things would make him an invaluable asset to the Pan-African movement in London and Ghana in the future.

As the son of a successful business owner, Makonnen was expected to leave the West Indies to continue his education, studying law or medicine after secondary school. Thus, in 1934 Makonnen enrolled at Cornell University where he was quickly embraced by the Ethiopian student population and even changed his name to T. Ras Makonnen in solidarity with Ethiopia as Italy prepared its 1935 invasion. ${ }^{428}$ During this time, Makonnen had a brief flirtation with communism and was also exposed to critical studies of British imperialism and racism through the texts of Jamaican Pan-Africanist,

${ }^{428}$ Kwesi Kwaa Prah. Beyond the Color Line: Pan-Africanist Disputations: Selected Sketches, Letters, Papers, and Reviews. (Trenton, NJ: Africa World Press, 1998), 21. 
Theophilus Scholes. ${ }^{429}$ Observing that Europe would be the place where "things were coming to a head," Makonnen traveled to Denmark, which was known as a refuge for many Europeans fleeing fascism. There he enrolled at Lanbo Højskole, the Royal Agricultural College in Copenhagen; however, he was deported to London in 1937 for protesting Denmark's exporting of mustard to Italy, which he felt was being used for the mustard gas in the war against Ethiopia. ${ }^{430}$

\section{Self-Sufficiency and Pan-Africanism:}

In London Makonnen immediately became involved with the Pan-African movement's protests against the Italo-Ethiopian War. He quickly became close friends with George Padmore, with whom he shared a home and co-founded the International African Service Bureau (IASB). Makonnen even drafted the IASB's constitution and served as Advisory Editor of the IASB's Internationalist African Opinion, a printed monthly paper on which he worked closely with Jomo Kenyatta and Eric Williams. Prominent revolutionary writers like Padmore and CLR James looked to Makonnen for topics to cover in their articles and he would sell the newspaper at protests and leftist meetings to raise capital for the organization. According to Makonnen the purpose of creating these organizations was to break with the old age tradition of blacks depending on white organizations, especially as it pertained to funding. ${ }^{431}$ Furthermore, while Makonnen had his own criticisms of Garvey, his desire to be a purist in terms of economic empowerment and racial self-reliance were indicative of Garvey's influence on

\footnotetext{
${ }^{429}$ Hakim Adi and Marika Sherwood. Pan-African History: Political Figures From Africa and The Diaspora Since 1787. (London: Routledge, 2003), 117.

${ }^{430}$ Makonnen. Pan-Africanism From Within. (1973), 111.

${ }^{431}$ Ibid., 178.
} 
his conceptions of Pan-Africanism. Makonnen's formulation of Pan-Africanism was based on his view that there should be solidarity amongst Africans living in North America, Africa, and South America. He believed that people of African descent, especially organizations like the IASB, should hold a watching brief over the African world, constantly prepared to move whenever some case of colonial or police brutality came to light. Makonnen called this "Practical Pan-Africanism." ${ }^{432}$

At the outbreak of the Second World War, Makonnen moved to Manchester where he enrolled in Manchester University to study History. Since Manchester bolstered a large Black community, Makonnen found a prime location to place PanAfricanism into practice. Noticing the city's limited number of spaces for Blacks, Makonnen drew upon the business acumen he observed in his father in British Guiana. Using his own savings he managed to open a number of successful businesses on Manchester's Oxford Street including three restaurants, the Ethiopian Teashop, The Cosmopolitan, and The Orient; two night clubs, the Forum Club and Belle Etoile, and a number of rental properties for people of African descent, and a bookshop, called The Economist, to cater to Black students at Manchester University. Among his sixty-two employees were Africans, West Indians, and Chinese immigrants living in Manchester. ${ }^{433}$ Makonnen was also fortunate enough to benefit from the constant arrivals of West Indian and African seamen and African American troops passing through Manchester who would flock to his businesses. Furthermore, it was clear to anyone walking down Oxford Street at this time that it was Makonnen's Main Street.

\footnotetext{
${ }^{432}$ Ibid., Xv.

${ }^{433}$ Hakim and Sherwood. Pan-African History. (2003), 119.
} 
Makonnen's success in business even caused the staunch socialist Padmore to jokingly say "You damn businessman; you'll become an octopus and we'll have to restrain you."434 Interestingly, while he was not an unwavering socialist like his peers, Makonnen seemed to mimic history as his role in securing independent funding for the Pan-African Movement paralleled Engels, whose father had become wealthy in Manchester, which enabled him to support Marx in his scholarly undertakings. Consequently, Makonnen understood that the movement required capital to carry out its objectives, which caused him to neither regard his business ventures nor their profits as his own, but rather it all belonged to the Pan-African Movement. As a result, the capital derived from these businesses, allowed him to finance most of the Manchester PanAfrican Congress and to feed and provide lodging for most of the Congress' attendees. ${ }^{435}$ More than anything, Makonnen took pride in the fact that "nobody could suggest [the movement] had been produced with Moscow gold or other white funds." ${ }^{436}$ In his view the rapidly growing Pan-African movement should be racially self-sufficient, as he wanted to avoid the risk of having a group of whites claim later that had it not been for them, independence would never have been gained. Furthermore, Makonnen was avoiding the common mistake of Black organizations with white membership that relied on white philanthropy for funding, as had been the case for the National Association for the Advancement of Colored People in the United States and the League of Coloured People in London.

\footnotetext{
${ }^{434}$ Makonnen. Pan-Africanism From Within. (1973), 146.

${ }^{435}$ Kwaa Prah. Beyond the Color Line. (1998), 22.

${ }^{436}$ Makonnen. Pan-Africanism From Within. (1973), 145.
} 
During his time in Manchester, Makonnen made regular trips to London where he and Padmore founded the Pan-African Federation. In 1945 CLR James wrote a note to him about "an exceptional fellow" named Kwame Nkrumah. According to James, Nkrumah was "not a liberal. He's one of the boys," meaning that he, like the London group, was anti-colonial in his thinking and embraced a socialist influenced PanAfricanism as fundamental to African liberation. ${ }^{437}$ Describing his first time meeting with the young Nkrumah, Makonnen recalled that he had a mark on him that made it apparent when one met him that he would become a leader. This was no doubt in reference to Nkrumah's magnetic personality and his unwavering commitment to freeing Africa from colonial rule, which led to Nkrumah's positioning in the movement's leadership as Regional Secretary of the Pan-African Federation.

Nkrumah's connection with Makonnen and Padmore was instantaneous as the three men spent hours in Padmore's kitchen, sharpening Nkrumah's ideas on anticolonialism, African liberation, and fundamentals of organizing nationalist movements for independence. From these conversations, it was Makonnen that advised Nkrumah to drop out of his doctoral studies at London School of Economics to become a fulltime organizer for the Pan-African movement, which manifested in Nkrumah becoming VicePresident of West African Student Union, Secretary-General of the West African National Secretariat, and Secretary of the Pan-African Federation's International Secretariat. As a result of the immediate impact and reputation garnered by Nkrumah during his brief three-year tenure in London, he was recruited to return home to the Gold Coast in 1948. Makonnens influence was demonstrated early on as Nkrumah returned to

\footnotetext{
${ }^{437}$ Ibid., 154.
} 
Gold Coast, not as a journalist or a barrister, but as a fulltime organizer building a mass nationalist movement that secured independence in less than a decade, with PanAfricanism positioned as a foundational feature of post-colonial governance in Ghana. At the foundation of Makonnen's Practical Pan-Africanism was the belief that wherever they were and whatever their country of origin, blacks should be able to look after each other. In addition to leading the larger Black community to complete economic, social and political control of their own destinies, he believed that PanAfricanism was also about dealing with individuals at the grassroots. As such, regardless of all the property and business success he had so quickly amassed in Manchester, Makonnen was prepared to leave it all behind just as fast at Nkrumah's request for his services in Ghana. Having concluded at the 1945 Manchester Pan-African Congress that the time had come for people of African descent to "make our freedom, assert our freedom in the land we have been defending all along," it was clear that Africa would be the staging ground for the next phase of the movement. ${ }^{438}$ Thus, in 1957 Makonnen accepted Nkrumah's invitation to aid in building the first independent Sub-Saharan African nation by working in Padmore's Office of the Advisor on African Affairs and in several other capacities that furthered Nkrumah's Pan-African policy and vision for Ghana.

The African Affairs Center And the All-African Peoples Conference Makonnen was a part of the collective of prominent figures from the African diaspora that were in attendance for Ghana's independence celebrations in March 1957. Regarded as "a man of fantastic energy and organizational gifts," Nkrumah would use

${ }^{438}$ Ibid., 168. 
Makonnen's abilities in a variety of aspects in Ghana. ${ }^{439}$ Once the parades and cocktail parties with foreign dignitaries had ended, Nkrumah and his government set out to place Ghana on par with the other modern nations of the world. Central to Nkrumah's plans for rapid development was the Industrial Development Corporation which had as a general policy promoting development and establishing new industries in Ghana.

Makonnen's first placement would be in the Industrial Development Corporation's State Bakeries. In less than a year, Makonnen was able to not only register the first profit the State Bakery had made in years, but to also expand the operation beyond Accra, building a chain of ten mechanical bakeries with distribution in major Ghanaian towns like Tamale, Ho, and Kumasi. ${ }^{440}$ According to Padmore, Nkrumah's Advisor on African Affairs, Makonnen was "doing an excellent job" with State Bakeries and making it more profitable; however, by August 1958 he advised Nkrumah to "see Makonnen more often" and to chat with him on general matters. ${ }^{441}$

The "general matters" Padmore was referring to involved his Office of the Advisor on African Affairs and Nkrumah's new Pan-African policy. The aim of Ghana's Pan-African policy was to attract as many African liberation movements as possible to Ghana and Nkrumah's ideologies with the ultimate goal of forming a united front of nationalist parties to establish a continental government. ${ }^{42}$ Following the independence celebrations African nationalists, many of whom were contacts from the London days, began to flock to Ghana for various reasons and providing accommodations for them

\footnotetext{
${ }^{439}$ Cyril Lionel Robert James. Nkrumah and the Ghana Revolution. (Westport, Conn: Lawrence Hill \& Company, 1977), 76

${ }^{440}$ George Padmore to Kwame Nkrumah, August 19, 1958, GH/PRAAD/RG/17/1/104; and Makonnen. Pan-Africanism From Within. (1973), 252.

${ }^{441}$ George Padmore to Kwame Nkrumah, August 19, 1958, GH/PRAAD/RG/17/1/104.

${ }^{442}$ Matteo Grilli. Nkrumaism and African Nationalism. (Palgrave Macmillan, 2018), 100.
} 
became a struggle for Padmore. Padmore first realized this during Ghana's first independence anniversary celebration in March 1958, as he noticed there was no institution capable of hosting African nationalists like Nnamdi Azikwe and Djibbo Bakary.

By August of that year, the issue had become unmanageable and could no longer be ignored. Padmore wrote to Nkrumah noting the difficulty in finding accommodation for nationalists from various French territories scheduled to meet with him to discuss certain matters. ${ }^{443}$ Ghana could not live up to its promises to aid African freedom fighters, nor could it place itself among the modern nations of the world if they could not even adequately host its visitors. At the time groups from various countries were coming to Ghana and "living like kings, taking a bottle of whiskey here and there, and charging it to the government." ${ }^{444}$ With his office being overwhelmed with requests for accommodation, and local hotel bills becoming excessive, Padmore consulted Makonnen regarding the situation.

Ghana's lack of the infrastructures to host African freedom fighters and dignitaries was a critical issue that was not lost on Makonnen, especially since he was on the chair of the planning committee of the quickly approaching All-African People's Conference (AAPC). After discussing the matter with Padmore, Makonnen quickly informed him that there were a number of empty government houses in the Cantonments that could be set aside for use when these African nationalists visited Ghana. Given Nkrumah's significance to African decolonization Makonnen maintained that "if we in Ghana were going to provide any lead, it was essential that there should be facilities

${ }^{443}$ George Padmore to Kwame Nkrumah, August 19, 1958, GH/PRAAD/RG/17/1/104.
${ }^{444}$ Makonnen. Pan-Africanism From Within. (1973), 212. 
whereby visiting revolutionaries or freedom fighters could be accommodated and made useful themselves and to the development of an African ideology. There had to be accommodating structures, and this was a desperate need." ${ }^{445}$ Furthermore, given his success in Manchester in the restaurant business and managing hostels for the Manchester 1945 Congress, Nkrumah agreed with Padmore that Makonnen was the most qualified to oversee the operation. As such, with Nkrumah's approval, Makonnen was charged with building the African Affairs Centre to be a facility that accommodated visitors and provide a space for them to congregate and strategize for Pan-African liberation.

Being in September 1958, Makonnen formed the Centre through his own initiative finding a facility near the Accra airport with twenty-five chalets. Its proximity to the airport also made it a perfect location, as it provided for quick entry and exit by African revolutionaries seeking asylum in Ghana. Since the buildings did not need serious renovation, most of Makonnen's resources could be focused on furnishing the facility. He quickly made use of his restaurateur expertise by establishing a field kitchen on the grounds and hiring women to wait on guests, whom he trained himself. While the Centre operated under and received funding directly from Padmore's Office, Makonnen refused the appropriation to deal with the costs of furnishing the Centre. Instead of directly receiving money, he merely requested the right credit from the government for the things he needed. Once his permission to credit was granted he ordered hundreds of sheets, pillowcases, and utensils; and hired the Public Works Department for the construction of a mess hall that could hold one hundred people, and a larger hall to accommodate two-hundred people. Admittedly, since the budget for the Centre was not

${ }^{445}$ Ibid., 212. 
large, Makonnen also approached a contractor who was making an exorbitant profit from the government and blackmailed him into giving concrete and building materials free of charge. According to Makonnen, he was even able to squeeze $£ 10,000$ in blocks and tiles out of a single vendor. ${ }^{446}$ The result was that the Centre was more than prepared for the AAPC, where its true purpose would be placed on display.

\section{The African Affairs Centre and Pan-Africa}

Makonnen being assigned to establish the African Affairs Centre was also fitting, given that he was also serving as the Chairman of the Planning Committee and the Financial Committee for the All-African People's Conference. As a result, he was responsible for securing accommodations for delegates from twenty-eight countries, and sixty-two nationalist organizations meeting in Ghana for the purpose of further strengthening African unity by encouraging the various African nationalist political movements to support each other in their colonial territories in their struggles for independence. Nkrumah's speech at the conference reiterated that for the final objective of Pan-Africanism to be achieved, freedom and independence must be achieved; unity and community between African states must be fostered, and the economic and social reconstruction of Africa must take place. ${ }^{447}$ He also argued that African liberation was the task of all Africans and Ghana would serve as a base for creating a broad united front for the speedy liberation of Africa. The AAPC brought together a diverse group of African freedom fighters including African nationalists in non-independent colonies; leaders from revolutionary African states; and Leftist opposition movements in

\footnotetext{
446 Ibid., 214.

${ }^{447}$ Kwesi Armah. Peace Without Power: Ghana's Foreign Policy, 1957-1966. (Accra: Ghana University Press, 2004), 61.
} 
independent western puppet states, all culminating in a rededication to the ideals of PanAfrican unity. Furthermore, the conference has been called the true successor to the PanAfrican Congress in Manchester, and just as Makonnen played a key role in 1945, he did the same in Ghana in December 1958. ${ }^{448}$

Reflecting on the conference, Makonnen recalled that the AAPC signified the end of the old pan-Africanism of five thousand miles away, and the beginning of a new breed in Africa itself. More importantly, it was taking place on African soil and presented an opportunity for Ghana to share what they had learned about the role of former colonial powers in post-colonial states. Chief among the lessons learned in the nation's infancy was the bitter experience of having white advisors and civil service employees in place of undertrained Ghanaians, and the realization that the fight for freedom would not end immediately upon gaining independence. In addition to this Makonnen observed that two types of meetings took place at the conference: the official one at the conference hall where the heads of states would be surrounded by foreign press and talking in general terms about the future of Africa; and the unofficial meetings at the African Affairs Centre with trade union leaders mixing with ideological groups from various countries to discuss practical questions of liberation. The Centre quickly become not only a hostel for refuge but also an institution for spreading Nkrumah and Padmore's ideologies of PanAfricanism to other liberation movements in attempts to bring them under the influence of Ghana's leadership.

While the various elements of the African liberation ideological spectrum were finally in conversation with each other at the Centre, Makonnen did notice that the

\footnotetext{
${ }^{448}$ Ibid.
} 
Egyptian delegation was hard at work making a determined bid for the loyalty of some of the freedom fighters in attendance. In response to this Makonnen met with members of the planning committee and declared that "we've spent all this money bringing these various delegations to Ghana, so we don't want the damn Egyptians using the opportunity to spread their influence with theirs cells, Muslim Brotherhoods, and God knows what else." ${ }^{449}$ While Makonnen was accused as being too chauvinistic, this was the same message of self-sufficiency and purism that he promoted in Britain, as he maintained that the African revolution Ghana was waging must be controlled by Africans and not those elements in Egypt who had one foot in Africa and another in the Middle East. This also reflected the rivalry among independent African states for influence throughout Africa, especially Egypt and Guinea, and brings context to the urgency with which Nkrumah's Pan-African policy was being pushed throughout the continent. Makonnen viewed his work and that of the other Pan-Africanists in Ghana as part of a great tradition, that demanded the preservation and proliferation of their ideologies and influence to support African liberation. As such, more than anything, Makonnen was personally invested in the work that he was doing in Ghana and viewed his work at the Centre as a vital component of the current phase of the Pan-African Movement.

\section{Cultivating Pan-African Ideology:}

In addition to providing a place of refuge and space for freedom fighters to congregate during their time in Ghana, Makonnen was also intent on providing training at the African Affairs Center. From the time he was assigned the task of building the Centre Makonnen's concern was that:

${ }^{449}$ Makonnen. Pan-Africanism From Within. (1973), 214. 
Ghana should have something to instil [sic] in our kinsmen in other lands. They should receive from our example the feeling that now they had a duty to perform; they were not any longer to wait meekly for independence to be handed to them on a silver platter, but to work for it with an awaken conscience. ${ }^{450}$

Additionally, he believed that if Ghana was to lead, it needed to provide facilities for visiting revolutionaries to develop an African ideology. More importantly, he foresaw that Ghana had to provide training as well as a refuge and that Nkrumah and Ghana would be fools to let the communists or Nasser, President of Egypt, train these revolutionaries and instill in them their own particular biases.

In June 1960, Nkrumah officially named Makonnen the Director of the African Affairs Centre and instructed him to "formulate vital programs to meet the needs of our African kinsmen," which he had already been doing under his own initiative. ${ }^{451}$

Nonetheless, Makonnen recognized that the Centre had been operating without a precise

list of objectives and in response, he wrote to Nkrumah:

I would like to know really what role or function would you like the Centre to undertake. Do you my dear Prime Minister like the Centre to be a closed shop - a seclusive retreat for people with a mission known only to you and your exclusive lieutenants, or do you want it to be a hospitality centre for dedicated nationalists and their allies in revolt against colonialism and its endemicills? For those who have found it impossible at present to carry on the struggle in their own country and have retreated temporarily to rehabilitate and return to the struggle at a time considered suitable to them? Or would you want the Centre to take on the appearance of prevailing centres to be found in other countries [...] Each while appearing to be dissimilar in function nevertheless had a common objective depending on the needs for which they are created to serve. Upon your instructions I shall endeavour to prepare a workable programme to conform with your demands. ${ }^{452}$

\footnotetext{
${ }^{450}$ Ibid., 211.

${ }^{451}$ Kwame Nkrumah to T. Ras Makonnen June 17, 1960, GH/PRAAD/RG17/1/7.

${ }^{452}$ T. Ras Makonnen to Kwame Nkrumah, June 22, 1960, GH/PRAAD/RG17/1/7.
} 
There is no record of a response to Makonnen's letter from Nkrumah, which may reflect the faith that Nkrumah had in Makonnen's expertise in institution building. It could also point to Nkrumah's trust in Makonnen as a Pan-African revolutionary of the "old guard" to build what would be the site from which Ghana's Pan-African policies and ideologies would emanate to the rest of the continent.

For Makonnen, Ghana was to be the vanguard of the African revolution and an ideological message had to be conveyed to visitors to demonstrate what they were about. This ideology message placed an emphasis on the use of Pan-Africanism and socialism as a vehicle for independence, industrialization and economic freedom, with the eventual goal of a Union of African States predicated on the adoption of the African personality and the maintenance of world peace. ${ }^{453}$ These basic messages and principles for African liberation would later formulate the basis of the ideology known as Nkrumaism. As a result, Makonnen set about educating the Centre's visitors on these ideologies and objectives by organizing specialized lectures for these hardened freedom fighters three times a week at the Centre. Using Padmore and Nkrumah's books Makonnen explained the nature of British, French and other imperialists as decolonization became a larger issue. ${ }^{454}$ Makonnen also had the Ghanaian government pay to have two thousand books, originally intended for Kenya, shipped to Ghana since they were collecting dust while being "tied up at the docks in Mombasa." ${ }^{455}$ Along with these, an additional fifty-six

\footnotetext{
453 "Nkrumaism a socialist philosophy." Accra Evening News, June 19, 1961, 5.

${ }^{454}$ See also George Padmore. The Gold Coast Revolution: The Struggle Of An African People From Slavery To Freedom. (London: D. Dobson, 1953); George Padmore. Africa: Britain's Third Empire. (London: D. Dobson, 1949); George Padmore. Africa and World Peace. (London: Routledge, 2019); George Padmore. The Life and Struggles of Negro Toilers. (Hollywood, Calif., Sun Dance Press, 1971); and Kwame Nkrumah. Towards Colonial Freedom: Africa In The Struggle Against World Imperialism. (London, Heinemann, 1062)

${ }^{455}$ Makonnen. Pan-Africanism From Within. (1973), 207.
} 
books were donated by the Israeli government, and a substantial book collection was amassed that eventually became the George Padmore Memorial Library. ${ }^{456}$

Also, buses were chartered to take visitors into Accra daily to experience Ghanaian culture, engage trade union affairs, or visit CPP party headquarters. Makonnen even organized language groups to improve the visitor's English and training in animal husbandry, co-operative dressmaking for the women, and even military training. ${ }^{457}$ These were the ways that Makonnen ensured that Ghana was living up to the promises of the AAPC and Nkrumah's own Pan-African policy, which was committed to supporting in every possible aspect the struggles of African liberation across the continent; however, the realities of government bureaucracy soon reared its head in the affairs of the Centre, and its ability to render service to the visitors that were pouring into the nation.

Furthermore, just as Ghana was prepared to open its doors to the refugees from across the continent, the nation found itself in competition with other independent states like Guinea and UAR who were also hosting African liberation groups in their nations.

\section{Issues of Protocol and Procedure:}

It was clear that Nkrumah's call to the Africa liberation movements had gone out and been heard near and far, as hundreds of refugees arrived at Ghana's borders, many without passports or documents. For many of these visitors, they had to be given clothes, food, and a place to sleep and it as left to the Centre to ensure to provide these things, look after them during their time in Ghana, and to keep the police updated on who was

456 “Israeli Books for African Affairs Centre.” Accra Evening News, May 12, 1962, 6.

${ }^{457}$ For more on Chinese military training at the African Affairs Centre, see: Republic of Ghana, Ministry of Information and Broadcasting. Nkrumah's Subversion In Africa: Documentary Evidence of Nkrumah's Interference In The Affairs of Other African States. (Accra: Ministry of Information and Broadcasting, 1966) 
entering and exiting the country. Just as Padmore felt weighed down by the processes of Ghanaian governmental bureaucracy, so too was Makonnen in dealing with the issue of refugees and the lack of a clear protocol on how to select host the visitors flocking to Ghana. As hundreds of refugees arrived, the Ministry of External Affairs and the civil service was unprepared to deal with the matter and Padmore forced the debate over the issue of a selection process, provisions of political asylum for freedom fighters, and matter of granting Ghanaian passports to refugees. As Padmore and the Ministers debated the matter, Ghana remained without a clear policy or legislation and began to risk losing its standing as the leading nation influencing African liberation, as nations like Guinea were swiftly granting passports to refugees passing through the nation.

The issue of bureaucracy, policy and protocol in this situation was observed by Makonnen in his comments on Nkrumah, noting instead of being bound by the red-tape of bureaucracy, Nkrumah was a rebel who would cut through the talk saying "What's all this? We have a job to do. We have created this state, and its citizenship is ours to do what we like with." ${ }^{58}$ While Makonnen seemingly praised Nkrumah here for his rebel approach to cast aside bureaucracy, there was merit in establishing and maintaining chains of command and legitimate processes for governance. Without these, the government could descend into chaos as it operated at the whims and wishes of its ministers and heads of state. Ultimately, this chaotic style of governing would come to characterize Nkrumah's approach to governance in Ghana in his later years and contribute to his removal from office.

\footnotetext{
${ }^{458}$ Makonnen. Pan-Africanism From Within. (1973), 154.
} 
Although Nkrumah supported Padmore's position, the process of adopting an official policy on refugees emerged after months of proposals and debates, which left Padmore's Office embarrassed and demonstrated that the urgency of Nkrumah's PanAfrican was not a priority of every person working in the Ghanaian government. This, however, did not stop Padmore and Makonnen from providing aid to African liberation movements that were arriving in Ghana. Refugees were received by Makonnen at the Centre and completely in his care from that moment. The issue of policy and protocol was indeed a pressing matter as the expenses of their accommodations and time in Ghana were being covered completely by the government. In most cases, these groups were outfitted with clothes, funding, military training, and offices to operate in Ghana.

Still, this Makonnen overcame this bureaucratic struggle and succeeded in carrying out Nkrumah's Pan-African policy. In May 1959, the Centre hosted its first registered refugees with the arrival of minority nationalist movements, the upécistes (UPC) from the French Cameroons, and the Comité de Défense du Sanwi Libre from Côte d'Ivoire. Groups like these often represented minority national parties that were defeated in elections. Another group hosted by the Centre was the Sawaba Party from Niger, which had been banned in Niger for opposing the majority party and welcomed to Ghana. These groups were welcomed and supported by Nkrumah and Ghana primarily because they were aligned with Nkrumah and the principles of Nkrumaism.

The Sawaba Party, who possessed a political affinity to the CPP's Pan-African ideals, were even granted party members upon arrival in Ghana. ${ }^{459}$ This was

\footnotetext{
${ }^{459}$ Minutes of the $4^{\text {th }}$ Meeting of the African Affairs Committee, November 9, 1959, GH/PRAAD/RG17/1/170.
} 
demonstrative of the mission of Nkrumah's Pan-African policy and the purpose of the African Affairs Centre, which was to expand Ghana's influence across the continent by welcoming freedom fighters into Ghana and exposing them to the political ideologies and strategies used by Nkrumah and the CPP to attain independence. Consequently, Nkrumah's support of minority political factions, in the form of funding, military training, and refuge in Ghana, often heightened tensions in foreign relations between Ghana and other African governments. An example of this was demonstrated in 1962 the Action Group of Nigeria were granted asylum in Ghana after being convicted of conspiracy against the Nigerian government. ${ }^{460}$ Nkrumah's investment and support of opposition parties in other nations lead to many African nations viewing Ghana and Nkrumah as power-hungry and with an agenda are ruling the entire continent themselves.

In many ways, Ghana's support of foreign opposition parties led to further division rather than the unity that Nkrumah was seeking, particularly in West Africa, amongst the Benin States where it was rumored that nations like Nigeria, Dahomey, and Togo were seeking to establish a union of states without Ghana. ${ }^{461}$ As a result, national security became a pressing issue as it pertained to the selection process for freedom fighters to take refuge in Ghana. This presented a difficulty as the identities of refugees needed to be cross-checked and verified upon arrival. Recalling the struggles of this issue, Makonnen maintained:

$[\ldots]$ the tragedy of our policy was that we took too much for granted when someone applied for a visa to enter Ghana. If he happened to have been a trade unionist, we dignified him as a Marxist; if he was an ordinary nationalist who failed to get into office, we called him an anti-colonialist. It was a terrible thesis and provided cover to a number of people who were barefaced opportunists. ${ }^{462}$

\footnotetext{
${ }^{460}$ Grilli. Nkrumaism and African Nationalism. (2018), 150.

${ }^{461}$ Makonnen. Pan-Africanism From Within. (1973), 232.

462 Ibid., 230.
} 
In the case of a group of South African freedom fighters arriving at the Centre in February 1960, Makonnen, who by then had amassed an extensive network of African freedom fighters, had no other choice than to consult a South African Group that had already been in Ghana for a preliminary screening before allowing the new gained entrance. ${ }^{463}$ This speaks to the difficulty of Nkrumah's open border policy, as identities, criminal records, and political affiliations needed to be verified for these individuals, and from a security standpoint, Ghana was taking a substantial risk in the process. Thus, while Makonnen and Padmore complained of the difficult and time-consuming process of political screenings, these procedures were necessary as spies or intelligence agents for imperialist nations posed a legitimate threat to Ghana, especially if they were being housed at the Centre.

\section{Makonnen's Contribution:}

Nonetheless, Makonnen's work with the Centre must be viewed as nothing short of a success and received international acclamation in October 1963 when the Centre was visited by Prince Sabbruddin Aga Khan, United Nations Deputy High Commissioner for Refugees. Following a tour conducted by Makonnen, he praised Nkrumah for his foresight in establishing the Centre early on in his term as head of state. ${ }^{464}$ While Nkrumah received the praise, it was the initial recommendations by Makonnen in August 1958 that initiated the Centre and his own labor and vision that built it into the institution the Prince was able to observe. Furthermore, when Nkrumah first approved of the Makonnen's building of the Centre, he envisioned it would follow a similar pattern to

\footnotetext{
463 Finance and Management Committee Minutes, February 17, 1960, GH/PRAAD/RG17/1/170.

464 “Osagyefo Lauded On African Affairs Centre.” Accra Evening News, October 7, 1963, 1.
} 
that of the International House in London and New York or the West African Student Union house that he briefly stayed in as a student in London.

Makonnen always felt that the Centre's emphasis was not solely for freedom fighters but to also serve as an institution where visitors to Ghana who may not be in a position to afford the expenses of hotel accommodation could find board and lodging at convenient rates and be in no way a disturbance. An example of such a visitor was exhibited in Mr. James M.K. Sengabi, a student from Uganda, seeking enrollment in Ghana's Flying School who stayed and was given accommodation at the Centre in December 1959. ${ }^{465}$ Sengabi, whose attempts to enroll in the British Air Force, Kenya Air Force, and the Indian Air Force, prompted him to offer his services in Ghana, and as he awaited approval he boarded at the Centre. This use of the Centre was in line with Makonnen's vision. He foresaw that once the African continent had been liberated, the Centre could be used in a number of capacities as either: a training institute for industrial education; a retreat for writers or journalists seeking solitude; a training site for government employees; or merely an overflow location for visitors. ${ }^{466}$

Makonnen carried out his objectives in conjunction with Nkrumah's wishes and evidence of his success manifested in the expansion of the property during his time as Director of the facility. Over the years Makonnen was able to add more buildings to the Centre and it became a popular spot in Ghana with thirteen houses named after parties hosted and eventually, after the nations they represented such as Ghana, Liberia, Guinea, Libya, Sudan, Morocco, Ethiopia, Togoland, Tunisia, UAR, Algeria, Nigeria, and

\footnotetext{
${ }^{465}$ African Affairs Committee Bulletin - Finance Committee 1959, $6^{\text {th }}$ Meeting of the Finance and Management Committee, December 3, 1959, GPRL/BAA/RLAA/248.

${ }^{466}$ Ghana Hotels \& Tourist Corporation, Letter from Makonnen to A.K. Barden, April 24 ${ }^{\text {th }}, 1964$, GH/PRAAD/RG/17/1/402.
} 
Cameroon. In addition to this, Makonnen had managed to construct an open-air theatre, and even a restaurant, with bands playing nightly. Eventually, the Star Hotel was built on the same site and by time Makonnen's years of management came to an end the government had gained an institution three times more valuable than when he took it over. By all accounts, Makonnen over-delivered on his endeavors and surpassed expectations with the African Affairs Centre. As a result, he became one of Nkrumah's closest advisors, a consistent presence in his committee meetings, and had a large influence on Ghana's Pan-African Policy as it was implemented by the Bureau of African Affairs.

The Bureau of African Affairs and the Multi-Talented Makonnen Makonnen's achievements in London and Manchester gave him notoriety in the Pan-African movement that made him one of the first candidates agreed upon by Nkrumah and Padmore to work in the Office of the Advisor on African Affairs. After being assigned to build the African Affairs Centre and exceeding all expectations, Makonnen became one of Nkrumah's most valued advisors on African affairs. As a result, upon the untimely death of his friend, George Padmore, in September 1959, Makonnen found himself among the collective of individuals selected by Nkrumah to form the Bureau of African Affairs (BAA) as a replacement to the Office of the Advisor on African Affairs and to continue the work begun by Padmore on a permanent basis. With the passing of Padmore, Nkrumah's closest friend, mentor, and advisor, Nkrumah maintained his distrust of the Civil and Foreign Service believing that its ministers and expatriate civil servant employees were merely in Ghana to serve the interests of 
Britain. ${ }^{467}$ This distrust of ministers and government employees also contributed to Nkrumah's growing desire to consolidate power with himself. As such, the Bureau was formed not only to continue carrying out the work of advancing Ghana's Pan-African policy but also for the institution and its actions to be directly under his control.

\section{Ghanaian Intelligence:}

As one of the Bureau's six board members, Makonnen served on the Bureau's African Affairs Committee, which functioned as an advisory board to share and discuss relevant topics, questions, and strategies on African Affairs. It was in these weekly Committee meetings that Makonnen's influence on Ghana and Nkrumah's Pan-African policy was most prominent. With the African Affairs Centre now operating under the Bureau's control, Makonnen was placed on the Bureau's Finance and Management Committee, which allowed him to oversee the funding of the Centre and gave him the ability to be a part of the vetting processes for refugees, like the Sawaba Party, seeking accommodation at the Centre. ${ }^{468}$ As a result of Makonnen's interactions with African nationalists and refugees passing through the Centre, he had built up an extensive network of contacts and was more knowledgeable about foreigners visiting Ghana. Since he was part of the preliminary screening processes for these individuals he was also informed on the political situations in their nations of origin, which made him a valuable asset in the formation of Ghana's first "Intelligence Service."

The formation of an Intelligence Service was an idea that Padmore was in favor of, as the information gathered from this service would assist in formulating concrete

\footnotetext{
${ }^{467}$ Armah. Peace Without Power: Ghana's Foreign Policy. (2004), 38.

${ }^{468}$ Minutes of the $4^{\text {th }}$ Meeting of the African Affairs Committee, on 9 November, 1959, "Sawaba Party," GH/PRAAD/RG17/1/170.
} 
plans for accelerating the achievement of African Unity. Furthermore, one of the service's initial concerns arose with the political situation taking place in Congo. It was Makonnen that was aware of a Congolese female national living in Ghana that could possibly be retained for the purpose of producing reports on Patrice Lumumba's Mouvement National Congolais (MNC) and Joseph Kasavubu's Alliance des Bakongo (ABAKO). However, fearing that her reports may "undeliberately be influenced by her tribe," Makonnen recommended that two Ghanaians be selected to be sent to Congo "under disguise to find out the shades of opinion of the various political leaders in the Congo."469 Reflecting not only Nkrumah's trust in Makonnen's contacts and intelligence within Ghana, but the African Affairs Committee also turned to him to select the two suitable and qualified individuals for this mission.

At the Bureau's Beck and Call:

In addition to establishing an institution for intelligence and helping Ghana become a staging ground for Pan-African liberation with the African Affairs Center, the Bureau regularly dispatched diplomatic and peace missions throughout Africa and the world. Part of Nkrumah's Pan-African policy was to seek African unity, which prompted the Bureau to send peace missions to quell clashes between African nations and in some cases political parties. An example of these missions came the Bureau's involvement in settling border disputes in North Africa between Algeria and Morocco, and in East Africa between Ethiopia and Somalia. ${ }^{470}$ Based on his own contacts made in Ghana at the

\footnotetext{
${ }^{469}$ Minutes of the $5^{\text {th }}$ Meeting of the African Affairs Committee, on 19 November, 1959, "The Situation In Congo," GH/PRAAD/RG17/1/170.

470 "Ethiopia-Somali border disputes." Accra Evening News, February 20, 1964, 1. "Osagyefo, The Man of Peace," Accra Evening News, February 20, 1964, 3.
} 
Centre and during his time in Manchester, Makonnen was able to advise Nkrumah on critical questions of Ghana-Togo relations and offered to make informal contact with Togo's Prime Minister, Sylvanus Olympio, when violence erupted at the Ghana-Togo border. Recalling how he conceived of his service to Nkrumah, Makonnen in his autobiography expressed that: "I am at your beck and call. If you want me to go to Central Africa, or to go to Nyerere or Obote to take the message then let me go. That's my job." ${ }^{" 771}$ Consequently, the Bureau and Nkrumah sent Makonnen on a number of diplomatic and peace missions to Guinea, Cuba, Israel, and British Guiana, his country of origin. ${ }^{472}$

Because of his success as a businessman in Britain and turning around the State Bakeries, Makonnen was viewed as someone that could assess and improve the operations of certain industries in Ghana. In early 1960, Makonnen was appointed President of the Industrial Co-Operative Society (IDUSCO) LTD. He approached this position with urgency as he immediately undertook a tour of the nation to obtain a general picture of the economic feasibilities of projects being proposed, to collect data and necessary information, and to scout provision site for future projects. ${ }^{473} \mathrm{He}$ also sought to promote development education through the IDUSCO by partnering with representatives of the German Democratic Republic Foreign Trade to open an exhibit showcasing educational equipment dealing with biological science and engineering in hopes of them being installed in schools throughout Ghana. ${ }^{474}$

\footnotetext{
${ }^{471}$ Makonnen. Pan-Africanism From Within. (1973), 174.

472 "Ghanaian Mission Meets Dr. Jagan.” Accra Evening News, February 20, 1964, 1.

${ }^{473}$ Industrial Co-Operative Society Report (IDUSCO) LTD, "Report of A Tour Made by Dr. T.R. Makonnen (President) from $5^{\text {th }}-16^{\text {th }}$ February, 1960." GH/PRAAD/RG/17/1/49B.

474 “Makonnen Opens Exhibition," Accra Evening News, May 23, 1960, 2.
} 
Eventually, Makonnen was also called upon by Nkrumah to serve Ghana as Managing-Director of the Hotel and Tourist Corporation, no doubt because of his success with the African Affairs Centre and in the restaurant business in Manchester, it was believed that he could also make this institution profitable. Makonnen took the position seriously, making the best fiscal decision for the corporation by opting to sign contracts with foreign firms with the best quality items for the best price, instead of merely taking contracts with British firms because of past relationships. ${ }^{475}$ He was also responsible for coordinating the accommodations for foreign dignitaries and public figures visiting Ghana, such as Yvonnen Whyte, Miss Jamaica in $1964 .{ }^{476}$ While he was in this position for less than a year, Makonnen was relatively successful in his endeavors as ManagingDirector, as he regularly cut expenditures, improved daily operations, oversaw the expansion of multiple hotels, and snuffed out corruption amongst hotel numerous hotel managers. ${ }^{477}$

\section{Makonnen and Ghanaian Media:}

In reference to the multitude of ways that Nkrumah and the Bureau made use of his contacts and expertise, Makonnen acknowledged that: "It's an endless process." 478 As Nkrumah sought to spread his Pan-African political thought throughout Africa, he understood that media would play a large role in this process. As a result, in 1959 he directed Padmore's Office to establish the famous Radio Ghana to broadcast political

\footnotetext{
${ }^{475}$ Ghana Hotels and Tourist Corporation 61-64, $6^{\text {th }}$ Minutes of the Sixth Meeting of the Board of Directors" on June 27, 1964, GH/PRAAD/RG/17/2/180.

${ }^{476}$ Ghana Hotels and Tourist Corporation 61-64, "Visit To Ghana Miss Jamaica," on June 26, 1964. GH/PRAAD/RG/17/2/180.

${ }^{477}$ Ghana Hotels and Tourist Corporation 61-64, "Memo to the Board," Letter from O. Adjarko to Makonnen on 24 June, 1964; Letter from Makonnen to J.K. Chinebuah on July 2, 1964; "Minutes of $3^{\text {rd }}$ Meeting of Board of Directors on May 5, 1964. GH/PRAAD/RG/17/2/180.

${ }^{478}$ Makonnen. Pan-Africanism From Within. (1973), 174.
} 
messages and to serve as a platform for African revolutionaries taking refuge in Ghana to broadcast important messages. Nkrumah was explicit in directing the Broadcasting Department that each news broadcast begins with the signature call: "This is the Voice of Africa coming to you from Radio Ghana, Accra." ${ }^{479}$ In December 1959, the African Affairs Committee decided that a select group of its members would deliver Radio Ghana's daily radio commentary, with Makonnen being assigned to personally deliver messages on African Affairs over the airways every Saturday evening. ${ }^{480}$

Making use of radio broadcast to spread Pan-Africanism and anti-colonial news was a new development; however, as a youth in British Guiana, Makonnen regularly acquired his news of the international Black liberation movement through print media outlets, like Marcus Garvey’s Negro World and the N.A.A.C.P.'s Crisis Magazine. Understanding the significance of print media in spreading news and fostering political agency, Makonnen replicated these outlets in his publishing ventures in London with the IASB's Internationalist African Opinion. Additionally, during his time in Manchester, Makonnen managed to raise capital to establish the Pan-African Publishing Co. Ltd, to publish a monthly journal for the Pan-African Federation called, Pan-Africa, which Nkrumah, Padmore, CLR James, and several other notable Pan-African figures contributed. As a result, Makonnen was called upon by Nkrumah and the Bureau to aid in building up the media component of Ghana's Pan-African policy. In January 1959, well aware of his extensive experience and success in editing newspapers and managing

\footnotetext{
${ }^{479}$ African Affairs Committee 4/12/59 - 6/9/60, Minutes of the $6^{\text {th }}$ Meeting of the African Affairs Committee, on December 4, 1959, “African Affairs News Broadcast” GH/PRAAD/RG17/2/501.

${ }^{480}$ African Affairs Committee Bulletin - Finance Committee 1959, Minutes of the $8^{\text {th }}$ Meeting of the African Affairs Committee, on December 17, 1959, "African Affairs News Broadcast," GPRL/BAA/RLAA/248.
} 
publishing companies, like the Pan-African Press, Nkrumah appointed Makonnen to serve as editor and head of the Guinea Press.

As the official publisher of Padmore's Office, he and Nkrumah were sure that Makonnen was the ideal candidate to deal with the tremendous amount of labor that a press needed. According to Makonnen, he was meant to help get the Guinea Press out of the red, because of the questionable spending practices of its former managers. Early on, it was not difficult for Makonnen to see where the money was going, as the former manager had twenty cars and a fleet of large trucks delivering its publications.

Makonnen quickly reduced this to two buses, a few motor bicycles, and made more use of railways for deliveries. ${ }^{481}$ Even though he was able to cut costs early on, Makonnen admitted that it was nearly impossible to work out a budget for the Press, as Nkrumah directed over $£ 60,000$ of its profits to be sent out to London to back a future publication in Britain. These funds would later be raised as a topic of discussion during Makonnen's imprisonment in the coup of February 1966, as the final destination of the funds sent to London were called into question.

In addition to overseeing the Guinea Press, Makonnen was also appointed by the Bureau to serve on the Editorial Committee of its official publication, The Bulletin on African Affairs. ${ }^{482}$ This publication was a monthly magazine on African Affairs geared towards providing the Ghanaian public with news and commentary on international matters concerning Africa. The Bulletin provided concise articles and the foreign speech by Ghanaian politicians on issues of the African political scene; however, in a January

\footnotetext{
${ }^{481}$ Makonnen. Pan-Africanism From Within. (1973), 222.

${ }^{482}$ Minutes of the $4^{\text {th }}$ Meeting of the African Affairs Committee on November 9, 1959, "Publication." GH/PRAAD/RG17/1/170.
} 
1960 meeting of the African Affairs Committee Nkrumah instructed the Editorial Committee that the contents of the Bulletin should remind its readers of their place in world politics and conform to CPP's political ideologies and the government's foreign policy. ${ }^{483}$ Such a publication was indeed necessary as the Bureau, in its accumulation and dissemination of information on Africa Affairs to further Ghana's Pan-African Policy, needed to ensure that Ghanaian citizens were informed of the current event in Africa as well. Unfortunately, Makonnen's time serving on the Bulletin's Editorial Committee was short-lived because of Nkrumah's directions for him to give full attention to the African Affairs Centre. ${ }^{484}$ While Nkrumah appeared to be asking Makonnen to focus on the Centre because of its significance to the Bureau and Ghana's Pan-African policy, he was also attempting to quell some of the tension between Makonnen and the Bureau's Secretary A.K. Barden.

Barden, Ghanaian Chauvinism, and Nkrumah's Consolidation of Power In spite of Nkrumah's attempts to develop Ghana and create a sense of nationalism and collective investment in the building of the nation, Makonnen recalled that many Ghanaians could not get away from being a "big man" and that most government employees were on a constant search in the corridors of power. ${ }^{485}$ This made the training of disciplined revolutionaries difficult, as according to Makonnen, CPP party members praised Osagyefo(Kwame), but in actuality, they all wanted to be Osagyefo. There was a common expectation among CPP members that the revolution was to pay off

\footnotetext{
${ }^{483}$ Minutes of the $10^{\text {th }}$ Meeting of the African Affairs Committee on January 14, 1959, "Platform Speeches." GH/PRAAD/RG17/1/170.

${ }^{484}$ Nkrumah to Makonnen June 17, 1960. GH/PRAAD/RG17/1/7.

${ }^{485}$ Makonnen. Pan-Africanism From Within. (1973), 207.
} 
in some way, especially with those that had been trained up in the party's ideals of revolutionary socialism and Pan-Africanism since the early 1950s.

For many, the CPP's movement and party membership were viewed as a profession, which caused a considerable degree of opportunism to manifest within the CPP and the government itself. Having so many contestants for every government position tended to cause more fragmentation and division in Nkrumah's regime than unity, which became an inhibitor as Nkrumah's political philosophies began to shift further to the left. This posturing by party members fostered what Makonnen referred to as the "colonial mentality," in which those in prominent positions in Ghanaian society sought to stock individuals from their own ethnic groups within government institutions. In addition to the tribalism still plaguing Ghanaian society, Makonnen, like Padmore before him experienced a degree of resentment because of his influence on Nkrumah, but also because of his West Indian origins.

Makonnen recalled that during this time in Ghana, one was inevitably the object of envy if you held a number of positions and were not Ghanaian. Since he was qualified to do so many jobs and shaping Ghanaian society from State Bakeries to its Intelligence Service, Makonnen naturally was the target of intrigue and resentment, from opportunists within the Nkrumah government. He observed this opportunism particularly in A.K. Barden, a Ghanaian ex-serviceman that Padmore had brought on as his assistant and stenographer. Padmore took to Barden quickly and poured into him the same mentorship he afforded Nkrumah in their London days. He trained Barden to be a radical PanAfricanist, and in doing so Barden was able to form a close relationship with Nkrumah, through Padmore, and upon the untimely death of Padmore, Barden was selected by 
Nkrumah to lead the Bureau of African Affairs. Several of Nkrumah's advisors and ministers protested his appointment, as many believed he lacked the experience to lead. Makonnen, who viewed as little more than an opportunist and "a police boy," found himself among these individuals that were taken by surprise when Barden was named as Padmore's successor. ${ }^{486}$

Early on he observed Barden serving as Padmore's stenographer, using the information from letters between Padmore and Nkrumah to integrate himself with those who wanted to be in the know. As a result, while Barden had gained Nkrumah's trust, Makonnen remained suspicious of him, even after he became Secretary of the Bureau of African Affairs. Nkrumah also reorganized the Bureau, replacing the African Affairs Committee with a Board of Directors comprised of Makonnen, five other individuals, and Barden running the organization. This allowed Barden to become one of the most powerful persons in Ghana in a short period of time. Makonnen maintained that upon being appointed, Barden quickly moved to push him out of the Bureau to fill the board solely with Ghanaians of his choosing. ${ }^{487}$ Barden's immediate appointing of his close associate David Bosumtwi-Sam, to serve as Administrative Secretary of the Bureau on the grounds of "his skills," may have been demonstrative of Makonnen's observation. In addition to this Makonnen believed that Barden had his eyes set on bringing the African Affairs Centre under his control as well.

In Nkrumah's reorganizing of Padmore's Office, he was sure to allow the Bureau and the African Affairs Center to function independently of each other. This did not stop Barden from disrupting Makonnen's business at the Centre with visiting African

\footnotetext{
${ }^{486}$ Ibid., 208.

${ }^{487}$ Ibid.
} 
nationalists. Makonnen recalled Barden's attempt to sabotage his relationship with Kenyan nationalist Jaramogi Odingo and Mbiyu Koinange once he demonstrated his extensive knowledge of the struggle in Kenya. According to Makonnen, once Odinga declared maybe "we should borrow this Makonnen for a spell, since he is so knowledgeable about Kenya," Barden warned him that: "Makonnen is somebody of dubious origin. Don't trust yourself with these foreign Africans." ${ }^{488}$ Similar to Padmore, Makonnen's character and morals were attacks simply because of his West Indian origins. Furthermore, the fact that Makonnen had known Nkrumah for decades, lived in Ghana since independence, and even married a Ghanaian woman, he was still subject to this Ghanaian chauvinism.

Makonnen saw this same resentment of not only non-continental Africans but also in the reception of non-Ghanaian Africans working in Ghana. During his time as Managing-Director of Ghana's Hotels and Tourism Corporation in Spring 1964, Makonnen was also responsible for managing the Black Star Line, which was based on the Marcus Garvey's original vision of promoting Pan-African commerce throughout the African diaspora. Furthermore, when the first Black Star Liner ship arrived in Takoradi, it was discovered that the majority of the sailors hired in Manchester had been Nigerian as opposed to Ghanaian. This prompted Kodwo Addison, head of the Kwame Nkrumah Ideological Institute and also a close associate of Barden, to urge Ghanaians to protest the foreign African seamen and demand that they are thrown out of the nation. Makonnen, having been present, immediately stepped in to address the seamen and said:

Most of you seamen know who I am: I was with you in Cardiff, Merseyside and other places. Take no notice of people who are trying to disturb the unity between

${ }^{488}$ Ibid., 221. 
Nigeria, Sierra Leone, and Ghana. We envisage a Black Star Line that will be manned by African regardless of a particular group. ${ }^{489}$

These sentiments from Barden and Addison reflects drastic departures from Nkrumah's own ideologies regarding his embrace of the diaspora and the unity of Africa. Perhaps there was a sense that since it was Ghana that was spending the money for African liberation, these positions should belong to Ghanaians. Thus, having the Secretary of the Bureau of African Affairs, which was responsible for promoting Ghana's Pan-African policy, and the head of the Kwame Nkrumah Ideological Institute, which was responsible for instilling a political education in the Ghanaian people based on Nkrumah's own ideologies, possess such views of non-Ghanaians contributing to work in Ghana, calls into question their commitment to Nkrumah's ideology.

In doing so it augments Makonnen's claims regarding opportunism within the Nkrumah government. Furthermore, the rebuking of people of African descent because they were not part of the Ghanaian family structure, directly contradicted Pan-Africanism and represented a form of Ghanaian nationalism that was becoming increasingly exclusionary rather than inclusive. Makonnen admits that eventually some of these attitudes made Nkrumah cautious about being too close to certain outsiders since they were not part of the Ghanaian family structure. Furthermore, in June 1960 when he officially appointed of Makonnen as Director of the African Affairs Centre, his instructions to devote his full attention to the Centre and to report directly and only to him, was less about separating the Centre from the Bureau or Makonnen from Barden, and more so about Nkrumah consolidating power and directing the flow of all information and decision making through himself. Another indicator of this

${ }^{489}$ Ibid., 220. 
consolidation of power was displayed by the fact that the Bureau's African Affairs Committee held its final meeting on March 17, 1960, as Nkrumah opted to discuss issues of African Affairs and Ghana's Pan-African Policy in private meetings with Barden.

It became increasingly apparent that Barden did not receive this position on his merit. Rather, Nkrumah's confidence in Barden stemmed not from his competence or unique qualifications, but rather from "his willingness to respond at all times to the many demands that were made, on his courage and loyalty in the liberation cause." ${ }^{" 490}$ This blind and unwavering loyalty was reflected in Barden's General Office Instructions that we sent out to each staff member of the Bureau, in which the first directive prescribed that "You will be loyal to the president of the Republic, the Nation, the Government and the CPP"491 While such a command may seem normal on its face, it suggests that steadfast loyalty and, above all else, obedience to Nkrumah and his decisions were requirements from anyone involved with the institution. Nkrumah's increasing emphasis on loyalty and obedience, and his curtailing of the channels through which information traveled, marked a clear departure from the representative mass-based political approach to governance that defined the CPP's movement and Ghana's early days of independence. Makonnen observed that these same demands of loyalty and obedience went far beyond the Bureau and began to permeate throughout Ghanaian society as Nkrumah's a shift towards the Russian model of centralizing governance began to manifest. ${ }^{492}$

\footnotetext{
${ }^{490}$ M. Dei-Anang. The Administration of Ghana's Foreign Relations, 1957-1963: A Personal Memoir. (London: University of London, 1975), 29

491 "Office Instruction." GPRL/BAA/RLAA/319.

${ }^{492}$ Makonnen. Pan-Africanism From Within. (1973), 209.
} 
Socialism Without Socialists and Ghana's Benevolent Dictator

In 1954, Nkrumah declared that any person found to be an active Communist would be refused employment within the Gold Coast government. ${ }^{493}$ This stance was derived from Nkrumah's strategy of "Tactical Action" during the transitional period of apprenticeship governance under which the provisions for independence were being negotiated. By 1960 Ghana had ratified its Republican Constitution and officially severed all political ties with Britain. Faced with the task of building a nation, Nkrumah pivoted from his 1954 proclamation and declared socialism as a fundamental component of his vision for the new republic. Nkrumah also began to move away from African socialism, based on the "African Personality," which he favored since his days in the Pan-African movement.

During that time, Padmore and Makonnen were always critical of Nkrumah's double-dealing in the Pan-Africanism movement and the Communist Party of Great Britain. Makonnen had always maintained that regarding socialism people of African descent should: "Buy the book, Don't join the club!" meaning that if he was interested in socialism, he should extract what he needed from the ideology and apply it without the direction of British or Russian commissars. ${ }^{494}$ With the passing of Padmore, his ideological mentor and closest political advisor, Nkrumah's embrace of scientificsocialism, coincided with an increase in foreign advisors that facilitated his emergent ties

\footnotetext{
493 Thomas Howell, A., and Jeffrey P. Rajasooria, eds. Ghana and Nkrumah. (New York: Facts on File, Incorporated, 1972), 19.

494 Makonnen. Pan-Africanism From Within. (1973), 159.
} 
with socialist nations like, the Soviet Union and China, who stood as examples of thriving industrial socialist states. ${ }^{495}$

In the early 1960s, Ghana formed political "Friendships" and a symbolic treaty of economic and cultural ties with both nations. ${ }^{496}$ The Soviets, in particular, were held in high esteem for their handling of two themes that were directly applicable to Ghana. First, the USSR was praised for its anti-tribalism, as the Soviet Union united 600 million peoples with distinctive ethnic and national backgrounds, dialects and cultures under a common heritage and forming "the greatest federation in world history." ${ }^{\prime 47}$ Secondly, the Soviet people were lauded for pooling their resources together to develop into a socialist state "reflecting the best in humanity, leading scientific and technical progress in our modern age. ${ }^{498}$

In his reverence of Lenin, Nkrumah maintained that for Lenin "revolution was always for him a moral issue for the realization of social justice... he succeeded in establishing a new social system that had made a remarkable impact on the course of world history." ${ }^{499}$ As a result, Nkrumah modeled much of his socialist policies and rhetoric from Lenin and the Russian model for development and modernization. From the Russian view, there was little to distinguish Nkrumah's idea of socialism from the Russian brand of orthodoxy and consequently, the Russians looked upon the general direction of Nkrumah's policies with favor. ${ }^{500}$ Receiving the Lenin Peace Prize by

\footnotetext{
${ }^{495}$ Trevor Jones. Ghana's First Republic 1960-1966: The Pursuit Of The Political Kingdom. (London: Methuen \& Co Ltd., 1976), 18.

496 "Long Live Ghana-Soviet Friendship!" Accra Evening News, August 25, 1960, 2; and "Long live Ghana-China friendship," Accra Evening News, December 23, $1963,7$.

497 “Long Live Ghana-Soviet Friendship!” Accra Evening News, August 25, 1960, 2.

${ }^{498}$ Ibid.

499 "Kwame Nkrumah on Vladimir Lenin." The Spark, April 19, 1963, Dabu Gizenga Collection On Kwame Nkrumah, box 128-8 folder 164.

${ }^{500}$ Jones. Ghana's First Republic. (1976), 63.
} 
Russia in 1961, Nkrumah and government officials like Kofi Baako, then Minister of Defence and Leader of the House, viewed the achievement as recognition and legitimation of his plans for Ghana's ongoing socialist revolution. ${ }^{501}$

As a result, socialism was characterized as an ideology that sought to abolish exploitation and create a classless society free of oppression. In his seminal text, Consciencism he argues that the ideology of society displays itself in the particular political, social, moral, and historical context of that society. ${ }^{502}$ As a result, he maintained that any attempt to build socialism in Ghana needed to be pragmatically developed and adapted to the specific conditions and social factors present in Ghanaian society. Promising to apply socialist ideas to address African problems, Nkrumah was anointed "The Lenin of Africa," as socialism was promised to bring free healthcare, education, state farms, and nationalization of industry. ${ }^{503}$

The Russian model of the one-party state that became Nkrumah's socialist program was based on "work and happiness" which was cast as the only viable path to "a healthier, happier and more prosperous life for us all." Stressing the ideology's ability to uplift, socialism was said to provide the opportunity for the Ghanaian masses to once again make their contribution towards the fulfillment of our national purposes. ${ }^{504}$ While Nkrumah's socialism had shifted specifically toward scientific-socialism, his promotion of the concept centered around its framing as an African brand of Socialism, which presented it as an expression of solidarity with the anti-imperial world; non-alignment

\footnotetext{
501 "On receiving the Lenin Peace Prize." Dabu Gizenga Collection On Kwame Nkrumah, box 128-8 folder 164.

${ }^{502}$ Kwame Nkrumah. Consciencism. (New York: New York University Press, 1970)

503 "Hail, Lenin of Africa." Accra Evening News, May 3, 1962, 2.

504 "Socialist Reconstruction Demands Sacrifice." Accra Evening News, May 7, 1962, 2.
} 
with the western or eastern blocs; a social synthesis of human values, communalism, and modernization; and the view of the nation-state as an extended family system. ${ }^{505}$

\section{Socialism or Tradition?:}

Nkrumah and the CPP made innumerable attempts to inculcate Ghanaian society with socialism through ideological institutions, state-owned press, and party propaganda; however, Makonnen astutely observed that one the primary reason that socialism failed to take hold in Ghana was simply because "You can't build socialism without socialists."506 Central to this suggestion was the fact that, as Nkrumah sought to apply socialist principles to Ghana's economy, he failed to realize that the transactional nature and profit motive in Ghana's local economy had existed prior to colonialization. In Ghana, Makonnen observed a nation of people that had been engaged in international trade with a reciprocal relationship in commerce for centuries. As such, while it was easy to identify the foreign import-export companies during the colonial era as explicit forms of capitalist exploitation, that same analysis was not applied to what Makonnen referred to as the "Primitive Capitalism" that had existed in Ghanaian society. ${ }^{507} \mathrm{He}$ observed this primarily in, what he called, the "mammy system," which was run by the market women in Ghana since the days of colonization. Recalling his time in Ghana, Makonnen provides the example of the Market Women in the Asante capital, Kumasi, in reference to the primitive capitalism that Nkrumah was up against in his attempts to implement socialism in Ghanaian society.

\footnotetext{
505 James A. McCain. “Attitudes toward Socialism, Policy, and Leadership in Ghana.” (African Studies Review 22, no. 1 (1979): 150.

506 Makonnen. Pan-Africanism From Within. (1973), 238.

${ }^{507}$ Ibid., 240.
} 
These market women in Kumasi were vital to local economies in Ghana since the city's central location within the nation made it a major transfer point for imports, for local manufactures, and food crops. ${ }^{508}$ Makonnen, acknowledged their significance to local Ghanaian economies since market women often personally cultivated and mediated economic connections, with European import and export firms, such as the United Africa Company, to conduct their own independent business. He deemed these market women enterprises as "primitive" because of their "under-capitalized" nature, which paled in comparison to their European counterparts that were able to establish joint-stock companies with share capital. Central to his conception of capitalism was the exploitation of workers, from which capital was derived and accumulated, in both European and African contexts. As substitutes for expensive shops or showcases, Makonnen observed that these market women used their ten to fifteen children to tour a locality daily, with commodities to the doorsteps of potential consumers.

Likening these girls to the "match-girls" of Victorian England, Makonnen suggested there was a connection between the mammy system and child prostitution, as market women would instruct their pawns not to return with unsold goods, which provided for young girls to be taken advantage of in some cases. Makonnen regarded this system as a primitive form of capitalism; however, he alleged that in his discussions with colleagues and even Nkrumah the response was usually: "That's African socialism. Where are the exploiters?" 509 While this was viewed by most Ghanaian as "good tradition" or "family development," Makonnen viewed this as exploitation within the

\footnotetext{
${ }^{508}$ Gracia Clark. "Consulting Elderly Kumasi Market Women About Modernization.” (Ghana Studies 12, no. 1 (2009), 99.

${ }^{509}$ Makonnen. Pan-Africanism From Within. (1973), 241.
} 
domestic circle, as it was also children that awoke from their mats outside family houses to begin working on the kenke and pounding pepper to be sold. From Makonnen's perspective, the absence of industrial development in Ghana caused those analyzing the Ghanaian economy to look elsewhere for largescale exploitation; however, in his view, one did not have to look any further than the traditional family structure in Ghana to find exploitation.

In his view, African socialism became a line of propaganda used to explain away or mitigate what Makonnen perceived as exploitation in traditional Ghanaian society. In addition to this, Makonnen believed socialist sloganeering, in part, was being directed to the wrong sections of society, as European imperialism was viewed as the sole perpetrator of capitalist exploitation. It was Makonnen's perception that his criticisms of alleged primitive capitalism in Ghana garnered responses such as:

You're a bad man, coming here to pry into our family affairs. How can you be so inhuman as to attack those various relations who nursed me and brought me up to be the beautiful woman I am? ${ }^{510}$

What Makonnen, and ultimately Nkrumah, faced was a clash between traditional Ghanaian economic systems and modern conceptions of both capitalism and socialism. While there may be merit to Makonnen's position on exploitation, his notion of primitive capitalism is flawed as it fails to consider the perspectives of Ghanaians continuing a traditional approach to local commerce, nor the use of the capital derived from what he perceived as exploited labor. Ghanaians themselves judged these local economies by the livelihoods it provided. Moreover, they viewed these systems as operating with a commitment to mutual survival and dignity as they provide accessible entry points to

${ }^{510}$ Ibid., 243. 
ordinary citizens and incomes that were used to sustain communities and family life. ${ }^{511}$ As such, since these children, he viewed being exploited, were ultimately being cared for and contributing to the communal system of traditional Ghanaian society in which everyone possessed value in society, it was simply viewed by most as a form of African socialism.

Calling attention to this condition also raised a conundrum for Nkrumah, as the market women were among his strongest supporters during the early days of the CPP's nationalist movement. Furthermore, an attack on their system posed the threat of further disillusion with the government or even rebellion, which was increasingly plausible as corruption pervaded the government and Nkrumah consolidating power with himself. As a result, the CPP party's members' use of African socialism in their anti-colonial rhetoric served an additional purpose of legitimizing traditional Ghanaian social and economic structures to maintain the loyalty of the Ghanaian masses.

Makonnen believed that socialism should have been applied to directly address the needs of the Ghanaian masses, which required socialist planning to address underproduction and inefficiency in the agricultural and budding industrial sector. What he soon discovered was that there were very few serious attempts to examine the state of Ghana's economy. He called this "the worst of both worlds," as there was an abundance of socialist rhetoric in Ghana without actual socialist planning. Instead, he suggested that Nkrumah and the CPP government were more so interested in state capitalism than socialism, as demonstrated with overspending on development plans, and projects like

${ }^{511}$ Gracia Clark. “Consulting Elderly Kumasi Market Women (2009), 108-109. 
the Volta River Project that served to enrich western capitalists and ultimately continue their exploitation of Ghana's natural resources.

By the mid-1960s the Ghanaian government was full of Nkrumah's loyal sycophants and drenched in corruption. In Makonnen's view, socialism in Ghana had become a cliché, as Nkrumah's ministers and powerful party men, once the colonized masses parked their Cadillacs and Mercedes Benzes outside their government-funded bungalows; hosted foreign dignitaries on yachts; and awarded building contracts to foreign firms for their own benefit. ${ }^{512}$ As such, while socialism pervaded Ghanaian society and state media, the government had no apparent intention of putting it into practice, as the government and most individuals promoting socialist rhetoric were steeped in capitalism. Observing these conditions, Makonnen found it difficult to bring his concerns to Nkrumah, his former mentee, as Nkrumah had grown cautious of being too close to certain outsiders since they were not part of the Ghanaian family structure. Still, when Makonnen attempted to confront Nkrumah on the endemic levels of corruption in Ghana's political-economy he was demoted from Director of the African Affairs Centre and Managing-Director of Ghana Hotels and Tourist Corporation, removed from the African Affairs Committee, and sent back to State Bakeries. ${ }^{513}$

While Makonnen, returned to his former post and remained loyal to Nkrumah because of his commitment to Pan-Africanism, this act was demonstrative of the authoritative turn that Nkrumah had taken in the 1960s. Furthermore, while socialism purported to encourage open societies with a free press, the right of collective bargaining,

\footnotetext{
512 Makonnen. Pan-Africanism From Within. (1973), 244.

513 Gaines. American Africans in Ghana. (2012), 195; Minutes of the $8^{\text {th }}$ Meeting of the African Affairs Committee on August 20, 1964. GH/PRAAD/RG/17/2/391.
} 
and transparency in governance, Makonnen noted that by this time Ghana had instead become more of a closed society. ${ }^{514}$ By 1965, Nkrumah had achieved political centralization with a one-party state and consolidated the power of the state with himself as he micromanaged domestic, foreign, and Pan-African policy. Nkrumah had become what Makonnen referred to as "power sweet," as his economic and Pan-African policies, which Makonnen in large part contributed to building, had culminated in the deterioration of faith in the Ghanaian government and Nkrumah himself. This was the Ghana that, fellow Guyanese intellectual-activist, Jan Carew was invited by Nkrumah to enter as the final days of his rule approached.

${ }^{514}$ Makonnen. Pan-Africanism From Within. (1973), 236. 


\section{BLACK MIDAS AND GHANA'S BENEVOLENT DICTATOR}

By 1965, Ghanaian society was facing an imminent crisis and the end of the Nkrumah era. As Ghana pressed on it was confronted by growing discontent amongst its citizenry and forced to deal with the implications of Nkrumah's use of authoritarian legislature to central power with himself. These were the conditions encountered by PanAfrican intellectual-activist, Jan Carew, as he entered "the turbulences and infelicities of the chaos that is Ghana." 515 Carew was an internationally known author, artist, and activist that, like Padmore, Lewis, and Makonnen, had intimate knowledge of the Black experience from the West Indies, to the United States, and Europe. A man of their ilk, Carew was brought into Ghana to aid in building Ghana's Pan-African media platform and directly advise Nkrumah in his final days in power. This chapter argues that Carew entered Ghana at a tumultuous moment and upon witnessing the fruits of Nkrumah's despotic turn and failed financial planning, he provided sagacious and astute counsel to Nkrumah prior to his removal from office in a coup d'état in February 1966.

\section{The Gentle Revolutionary:}

Few West Indian Pan-Africanists of the mid-twentieth century have been able to amass a comparable international network, influence, and respect to that of Jan Carew. Born in the small town of Agricola Rome, in Guyana in 1920, Carew was the only son

\footnotetext{
${ }^{515}$ Letter to Carew, on January 20, 1966. “Correspondence from Others who were in Ghana (1966)," Jan Carew Papers.
} 
and middle child of Ethel Robertson and Alan Carew. His father, Alan, was a British Empire Loyalist, believing wholeheartedly that living under the British crown was the greatest blessing that life had to offer. ${ }^{516}$ On the other hand, his mother was a nationalist, meaning that she believed colonial rule to be an abomination, that fostered racial stratification and promoted the hierarchy of color, caste, and class in Guyana's population.

In addition to experiencing the conditions of British colonialism and the racial tensions between Africans and Indians in British Guiana, Carew learned of the implications of racial domination from his mother, who experienced jim crow racism in the United States. Early on in life, Jan found that growing up in a multiracial British colony brought about an acute awareness of race. Being of African, Indigenous, and European ancestry, Carew embodied the nuances of West Indian identity, as he found himself having to constantly reconcile the cultural and historical meanings of enslavement, emancipation, and human progress. ${ }^{517}$ He also carried with him the inextricable phenomena of living between the backward colonial society of British Guiana and traversing the modern world as a British subject, cultivated in Victorian English values as well as the revolutionary spirit of resistance that emanated from San Domingue and throughout the greater West Indies.

In 1944, Carew, like his West Indian comrades in Ghana, left his homeland in the West Indies to receive his education abroad. Like Padmore, Carew first attended Howard University and was quickly introduced to Jim Crow racism for the first time when he was

\footnotetext{
516 Jan Carew. Episodes in My Life: The Autobiography of Jan Carew. (Leeds, England: Peepal Tree Press, 2015), 19.

${ }^{517}$ Catherine Hall. "What Is a West Indian?" in West Indian Intellectuals in Britain, edited by Schwarz, Bill. (Manchester: Manchester University Press, 2003), 31.
} 
harassed by the DC police. Similar to Makonnen, Carew's studies eventually took him to Europe after earning a scholarship to study at Charles University in Czechoslovakia. During his time in Europe Carew passed through London where he met George Padmore, whom he considered a mentor for his generation who inspired in them a spirit of insurrection against the imperial binds of Europe. Carew like many Pan-African revolutionaries of the time had read Padmore's articles and books and heard the legend of his "007-type of escape" from Stalin's hitmen in the Soviet Union. ${ }^{518}$

Like Padmore, Carew came to spend a great deal of his time in London where he also became part of the Pan-African activist community and demonstrated nearly every day during the late 1950s and early 1960 s on a number of issues from immigration to South African apartheid. As atrocities like the Mau Mau Rebellion in Kenya, the Sharpville Massacre in South Africa, and Patrice Lumumba's assassination in the Congo, became increasingly common, Carew observed that "What is happening is that the slums of the Empire are coming too close to the doorsteps of the English." ${ }^{.519}$

The horrific murder of Lumumba, the first democratically elected Prime Minister of the Democratic Republic of the Congo, in particular, affected Carew more than any other political tragedy of the era, stirring within him a desire to seek violent action against whites on the streets of London. However, he instead opted to join other anticolonial activists at the Ghanaian Embassy in London to draw up a policy statement in support of Lumumba and calling for the demobilization of the Force Publique, which had brutalized the Congolese people since the days of the Conference of Berlin. Carew's use of the Ghanaian Embassy speaks to the Pan-African resources and institutions that Ghana

\footnotetext{
${ }^{518}$ Carew. Episodes in My Life. (2015), 60.

${ }^{519}$ Ibid., 144.
} 
and Nkrumah were providing, not only for African liberation movements in Africa but for anti-colonial activists in the home of the Empire as well. In doing so, Nkrumah was able to spread his and Ghana's influence on revolutionaries and activists throughout the African diaspora, allowing for the Pan-Africanism emanating from Ghana to be carried the boundaries of the third world.

\section{The Caribbean Writer in Exile:}

In addition to his activism, in London, Carew gained a reputation as a "Renaissance Man" because of the breadth of his talents and capabilities as an actor, playwright, art critic, broadcaster, journalist, and activist. Struggling to make ends meet, Carew turned to journalism, serving as a columnist for the Kensington Post, London Observer, served as an Art Critic for the Art News and Review, and wrote book reviews for John O'London's Weekly. Showcasing his acting skills, Carew joined the Lawrence Oliver Company and appeared in plays throughout Britain and the United States. Throughout the 1950 s and the early 1960 s, he regularly contributed to BBC broadcasts on art, literature, and current affairs on programs like Caribbean Voices, Home Service, and Third Programme. As he traveled the modern world, Carew always kept Guiana close to his heart, and position his homeland as the backdrop for his first major publication, Black Midas. In this seminal text, Carew highlights Guianese folk myth, language, and explores the nuances of race and class in post-colonial Guiana, through the perspective of porkknocker (a small-scale gem prospector) as the nation's natural wealth was exploited through its emergent diamond and gold industry.

The success of Black Midas, led to its publishing in several languages including Russian, causing Carew to travel to the Soviet Union as a guest to the USSR Writers' 
Union in 1963. While Carew had been aware of the Soviet Union's embrace of people's struggles in the third world, part of the reason for his visit was that he had amassed royalties from Black Midas but since the Soviets had not signed the Berne copyright agreement the funds from his royalties could only be spent in the Soviet Union.

Following a second visit to Russia, Carew was inspired to write another major text, entitled Moscow is not my Mecca, which explores the anti-black racism experienced by Black students living in Moscow. Determined not to author "a knee-jerk anticommunist work," Carew intended to disrupt the prevalent propaganda of Russia being a communist utopia and to "tell the truth about the rise of racism in the Soviet Union." 520 In doing so, the novel demonstrates how the presence of these Black exchange students from the West Indies and Africa, incited an inferiority complex derived from prevalent racial stereotypes in Russian society claiming these visitors from the third world were:

$[\ldots]$ hungry and illiterate, victims of imperialist greed and oppression ... we were never told that some of you had travelled to New York, Rome, London, Paris, and that we would envy you your clothes, your way of talking freely about things we don't dare to mention. ${ }^{521}$

Relying on the accounts of Black students, in Moscow is not my Mecca, Carew dismissed the USSR's persona as a model for newly emerging post-colonial states by depicting racist attitudes in Soviet society.

By highlighting experiences of Black exchange students with Russian students spitting in front of them, calling them "Black monkeys," and reports of racial violence, Carew continued a tradition of denouncing the popular Soviet propaganda of the time, that presented the USSR as a revolutionary, non-racist, and humanitarian alternative to

\footnotetext{
${ }^{520}$ Joy Gleason Carew, "Black Midas in Moscow: Conversations with Jan Carew." (Small Axe Salon 7, December 2011), http://smallaxe.net/sxsalon/interviews/black-midas-moscow.

${ }^{521}$ Jan Carew. Moscow Is Not My Mecca, (London: Secker \& Warburg, 1964), 90.
} 
imperialist nations of the West. As a result, Carew, placed himself in step with George Padmore (Pan-Africanism or Communism), whom he believed would have approved of the book, noting Padmore's emphasis on the significance of operating in a race first capacity, rather than the strict class-based approach preferred by many in the USSR and the international communist parties.

During this time, Carew also gained prominence within the London PanAfricanist network, befriending the likes of Jomo Kenyatta, Claudia Jones, Paul Robeson and W.E.B. Du Bois, who was on his way to Ghana to live permanently to work on the African Encyclopedia. Had Carew moved to London a decade earlier, there is no doubt that he would have been immersed in the Pan-African movement working alongside Padmore, Lewis, Makonnen, and Nkrumah. In 1965 Carew fleshed out his own PanAfrican ideals with Malcolm X during his visit to London. The two men, both the sons of socially conscious West Indian women, became instant friends and spent his entire weeklong visit together in London discussing his pilgrimage to Mecca, race relations in England, and Malcolm's monotonous meetings with Kwame Nkrumah in Ghana. ${ }^{522}$ In their discussions, Carew declared that he was "a socialist, a Pan-Africanist, a Black Marxist, a nationalist who believed in the cultural unity of the black world..."523 His Pan-Africanism had been demonstrated not only in his activist work in London but also in his work in the West Indies. A prime example was displayed in his call for unity within the West Indies following the failure of a Federation of nation-states to be formed. In a December 1962 article, entitled "Federation: Shadow or Substance?" Carew wrote:

\footnotetext{
${ }^{522}$ Malcolm X's mother was from Grenada, actively participated in the Universal Negro Improvement Association, and knew Marcus Garvey personally. For more on this see, Jan Carew. Ghosts in Our Blood: With Malcolm X in Africa, England, and the Caribbean. (Lawrence Hill Books, 1994)

${ }^{523}$ Carew. Ghosts in Our Blood. (Lawrence Hill Books, 1994), 34.
} 
Individual West Indian leaders, while trumpeting their advocacy of the idea of a centralized government, made sure that enough power remained in their hands to make this impossible . . . . The West Indies can no longer afford to carry on by plastering sores; cures must now be affected in the bloodstream of society. We live in an age of emergent coloured peoples, of revolutionary social change... The logic of a federation with a strong central government, planning for the whole area, giving to an uprooted peoples who were drawn from all over the earth a sense of nationhood, of identity, still remains unassailable. ${ }^{524}$

For Carew, a West Indian Federation, like the United States of Africa envisioned by Nkrumah was the most viable course of action for liberating the region and its people once and for all. However, as Nkrumah was also learning at this time with the Casablanca and Monrovia Blocs, these notions of unity and regional/continental federations, while logical and economically viable, were unattainable primarily because the leaders of these territories preferred to keep power over their government and nations with themselves. ${ }^{525}$

Carew also revealed to Malcolm, his believed that socialism was the only system through which the true histories of people of African descent could be sufficiently articulated, analyzed, and restored. As Malcolm was still refining his understandings of socialist ideology, he asked "What kind of socialism?." Having observed the varying forms of socialism practiced in Russia, the international Communist parties, and those emerging in the third world, Carew reiterated that his socialism was a "humane and resilient socialism that is sensitive to the rhythms of life and to all human needs-material, cultural, psychological, spiritual, collective, and individual. Above all, it must be a

524 “Federation: Shadow or Substance?" Flamingo (UK), December 1962, in Carew. Episodes in My Life. (2015), 170-172.

${ }^{525}$ The Casablanca and The Monrovia Groups were formed amongst African nations as the opted either for a unity continental federation of Africa states or political autonomy with co-operation amongst independent African nations. This eventually resulted in a compromise in the founding of the Organization of African Unity. For more on this see: Colin Legum. Pan-Africanism. (London: Pall Mall Press, 1962) 
patient and tolerant socialism"526 This is the vision that many anti-colonialist and Black socialists of the era, especially those conceiving of African Socialism, possessed as they envisioned a post-colonial world based on egalitarianism, humanism, and selfdetermination. Unfortunately, Malcolm X would not be able to see this post-colonial world, as he was assassinated less than a week after he left London. Following Malcolm's death, Carew, fed up from the racism in England and in need of respite, retreated to Ibiza, Spain to unwind and write in solitude, where he remained until receiving an invitation to work in Nkrumah's Ghana.

\section{Guiana Comes to Ghana Again}

On a brief trip to handle some business in London in Summer 1965, Carew received a telegram stating that the Director of Ghana's Publicity Secretariat wanted to interview him for an Editorship position in Ghana. ${ }^{527}$ The telegram had been sent by African American Pan-Africanist, Julian Mayfield, who had been working with Nkrumah in Ghana since 1961 as founder and Editor of the African Review and serving as the Director of Ghana's Publicity Secretariat. He had been in London as a member of a delegation that Nkrumah sent to the Commonwealth Prime Minister's Conference. Mayfield managed to track Carew down through his political network in London and invited him to breakfast at the Imperial Hotel. Speaking with an air of alertness, Carew could tell that Mayfield had not simply invited him to breakfast for a friendly conversation on the Afro-British and Afro-American experiences.

526 Carew. Ghosts in Our Blood. (1994), 55-56.

527 Telegram from Julian Mayfield to Carew, Summer 1965, Jan Carew Papers. 
Downing a gin and tonic, Mayfield confessed that he needed a reprieve from the fray in Ghana and that unless he could go somewhere quiet to recharge he would burn out. He then shared that President Nkrumah had agreed to let him take his leave, on the condition that he was able to convince Carew to take his place as Director of the Publicity Secretariat. ${ }^{528}$ Carew was flattered but confessed that he had retreated to Ibiza also for the purpose of taking respite. Well aware of Carew's reputation in Pan-African circles as an energetic and motivated activist, Mayfield admitted "We [in Ghana] know you were directly involved with the Mau Mau campaigned and the protest over Lumumba's assassination. You've hardly been under a rock." ${ }^{529}$ Handing Carew a contract, Mayfield told him he needed to report for duty in a month. This was an offer that Carew could not refuse, as all of his activism had been leading him to this moment.

Recalling his time with Nkrumah, Carew noted that he was very open to everybody and wanted to embrace the entire diaspora. Carew's presence in Ghana was a testament to Nkrumah's desire to practice Pan-African in this government, as well as his desire to actually seek out those with the best skills in the Black world to help build Ghana. Because of this Carew reveled in the chance to have an African leader with a Pan-African vision. ${ }^{530}$ Carew also counted himself among the many that believed that Nkrumah possessed the resources to realize the dream of a truly free African diaspora. As such, Carew never returned to Ibiza, and instead flew directly from London to Accra on Ghana Airways, via Rome. When Carew landed in Accra, it was his first time on African soil and the final days of Nkrumah's administration.

\footnotetext{
${ }^{528}$ Carew. Episodes in My Life. (2015), 215.

${ }^{529}$ Ibid.

${ }^{530}$ Ibid., 219.
} 
African Review, the Publicity Secretariat, and Press Censorship:

While Mayfield stayed on in Ghana for the first few months of Carew's tenure, Carew was extremely busy in his new position. He was immediately thrown into Mayfield's hectic schedule as Director of Nkrumah's Publicity Secretariat and Editor of the African Review. Mayfield founded and edited the African Review as a magazine of political economy that featured a radical analysis of the events in the United States and the African world. ${ }^{531}$ It was truly a major Pan-African magazine of the time with an internationalist strategy, as it sought to function as a forum for African and Third World revolution with a critical analysis of issues like neo-colonialism, the assassination of Malcolm X, apartheid in South Africa, and U.S. imperialism. ${ }^{532}$ Reflecting Nkrumah's own embrace of the African diaspora, the African Review was essentially a Ghanaian publication outfitted by diasporic blacks with Mayfield and Shirley Graham Dubois as co-editors, Jean Carey Bond providing editorial assistance, and contributing members from across the diaspora such as Preston King, Maya Angelou, St. Clair Drake, and Africana Historian John Henrik Clarke, who provide vital updates on matters in the United States.

Carew had also been a contributor to the African Review since its first issue in 1964, and prior to moving to Ghana. He had been a regular contributor to the magazine, having his most recently submitted article published in the magazine in October 1965.533 This article was a tribute to Malcolm X, as Carew derived the topic from his discussion on racism and politics in Britain. As such the article examined how the Windrush

\footnotetext{
${ }^{531}$ Gaines. American Africans in Ghana. (2012), 212.

532 Ibid., 222.

533 James Anokye to Carew, on 14 December, 1964, Jan Carew Papers.
} 
generation's migration to Britain, following World War II, had caused the issue of race and immigration to become a deciding factor in the nation's 1964 general election, specifically in the town of Smethwick. ${ }^{534}$ During his time in London, Malcolm expressed that he was profoundly concerned with these developments and made it a point to visit Smethwick for himself, following his lecture at the London School of Economics.

In his Review article, Carew honed in on the industrial British town of Smethwick where Peter Griffiths, a Conservative Member of Parliament of Smethwick had recently won a Labour seat with "racialist clichés from the sewers" and the slogan: "If you want a nigger for a neighbor, vote Labour." ${ }^{\text {535 }}$ This rhetoric bored a stark resemblance to the racial ideologies manifesting across the United States in response to the Civil Rights Movement. Subsequently, its emergence in Britain coincided not only with the mass influx of West Indians and Africans to British society but also as the British government was severing its ties with its former West Indian and African colonies. Understanding the racial violence that routinely followed this rhetoric in the United States where the Civil Rights Movement was at its peak, the comments made by Griffiths, as well as his victory, should have been a concern of the Africa world and Carew ensured that the African Review facilitated this conversation.

The magazine was extremely popular, with at least 15,000 copies of African Review in circulation by February 1966 for international consumption and subscriptions in diplomatic corps, embassies, etc. ${ }^{536}$ Among the magazine's foreign correspondents was David Dubois, the stepson of W.E.B. Du Bois, who had died in Ghana on the eve of

\footnotetext{
534 “The Choice Between Whom?" African Review, October 1965, 60., Jan Carew Papers.

${ }^{535}$ Carew. Episodes in My Life. (2015), 217; and "The Choice Between Whom?," African Review, October 1965, 60., Jan Carew Papers.

${ }^{536}$ Doris Davis to Jan Carew, on February 23, 1966., Jan Carew Papers.
} 
the March on Washington for Jobs and Freedom in 1963. Supplied with a new printing press from East Germany, the African Review was able to produce a high-quality publication; however, by February 1966 due to the chaos of Nkrumah's final days in office, the Africa Review was terribly behind schedule. In a letter to Carew, Doris Davis, who was over Art and Production for the magazine suggested that the "March issue may have to be dated April unless a miracle happens." 537 Before being sent out, the new issues went first to Nkrumah's office and then on to international markets for consumption, and to African nations still under the colonial rule where the magazine was often banned by colonial governments.

Taking over Mayfield's responsibilities in the Publicity Secretariat, Carew mostly produced unsigned material for broadcasting and reproduction in the national newspapers. In this capacity, Carew expected to occasionally be called upon to assist in drafting speeches or documents to be presented at international conferences. ${ }^{538}$ Prior to Carew's arrival, the African Affairs Committee, under the direction of Nkrumah mandated that institutions like the Bureau of African Affairs, The African Affairs Secretariat, and the All-African Trade Union Federation Secretariat should submit special programmes, feature articles, radio broadcasts, and general press regarding African Affairs and both domestic and international Ghanaian politics to be proofed by the Publicity Secretariat. ${ }^{539}$ Furthermore, the policy of the African Affairs Committee regarding press was that when in doubt, the Ghana press, specifically print media outlets like the Ghanaian Times, should consult the Publicity Secretariat for fact-checking, and

\footnotetext{
537 Ibid.

538 "Ghana in Perspective." Julian Mayfield Papers, box 13, folder 14.

${ }^{539}$ Minutes of the $8^{\text {th }}$ Meeting of the African Affairs Committee on August 20, 1964, "AATUF Publicity and Radio Campaign," GH/PRAAD/RG/17/2/391.
} 
authentication of statements and positions taken by Ghanaian politicians. ${ }^{540}$ This was to ensure all press releases were in line with the Nkrumah and the CPP government's policies and initiatives; however, it was also reflective of the increasing control that the Nkrumah had begun to exert over the press in Ghana.

An irony of this era in post-colonial Ghana was that Nkrumah, who founded and edited the Accra Evening News as a private newspaper prior to independence, turned his back on the very notion of press freedom upon which his nationalist movement was built. By the 1960s, as he began to consolidate power with himself, he increasingly refused to tolerate dissenting views or those that diverged from his own in the Ghanaian media. Following the 1960 referendum on the Republican constitution, which severed all political ties to Britain, all Ghanaian journalists were warned in an Evening News article that: "the Union will not tolerate misrepresentation and distortion of facts by journalists" and would recommend severe punishments without hesitation for any journalists that deliberately published a story ridiculing the government. ${ }^{541}$ Shortly thereafter, the National Assembly approved of a constitutional amendment enabling Nkrumah to use executive powers to inhibit the publication of any critical content that could potentially tarnish public opinion against the government or was "contrary to public interest." 542 While the state-owned Evening News' framed this amendment as a positive development, the amendment actually made it illegal to sell or distribute any newspaper, book, or document, which was considered contrary to the public interest and punishable with up to three years imprisonment.

\footnotetext{
${ }^{540}$ Minutes of the $8^{\text {th }}$ Meeting of the African Affairs Committee on August 20, 1964, "Ghana Press," GH/PRAAD/RG/17/2/391.

541 "Journalists must be devoted to Africa's freedom fight." Accra Evening News, June 20, 1960, 3

542 “Govt to prohibit vicious Newspapers," Accra Evening News, August 24, 1960, 8
} 
Additionally, in 1961 the National Assembly passed a bill imposing a fine of 500 pounds and/or three years imprisonment, on anyone convicted of publishing defamatory or insulting matter which might bring hatred, ridicule, or contempt upon Nkrumah. ${ }^{543}$ Among the Ghanaian newspapers affected by this law was the Kumasi-based Ashanti Pioneer, which had regularly criticized Nkrumah and the CPP since the 1950s. Following the government's censoring of the paper, the CPP government shut down the Pioneer in 1962. Also, the Pioneer's editor was detained for seven months, and the Pioneer's city editor sentenced to four and half years in prison for being critical of Nkrumah's government. Broadening this encroachment on the freedom of the press, the Newspaper Licensing Act was passed in 1963. This act required newspaper editors and publishers to obtain a license, from the government and made it virtually impossible to operate a paper without government authorization.

By the time Carew arrived in Ghana, these policies had been in effect for years. Furthermore, it is possible that these restrictions on the press, along with the corruption raging through Ghanaian society, contributed to Mayfield's seemingly desperate need for respite, as he had been working in Ghanaian media from the moment they had emerged. This censorship even extended to the University of Ghana, which became a stronghold from which criticism of Nkrumah and the government emanated. As a result of the government's interference and attacks on academic freedom, a number of foreign professors, including Pauli Murray and Conor Cruise O'Brien, eventually resigned in protest. It was clear that Nkrumah understood the power of the media and controlling the narratives and flows of information being disseminated within and out of Ghana. These

${ }^{543}$ Omari. Kwame Nkrumah, The Anatomy of an African Dictatorship. (1970), pp 92. 
were among the early manifestations of repressive legislation that facilitated the growth of corruption and Nkrumah's turn towards authoritarian governance in Ghana and the political environment that Carew had to navigate.

\section{Corruption and the Path to Despotism}

Carew originally stayed at the Star Hotel when he arrived in Ghana. This hotel was built on the same compound on which Makonnen chose and built the African Affairs Centre and oversaw the expansion of as Managing-Director of the Ghana Hotel and Tourism Corporation all those years ago. When Mayfield left Ghana, he and Carew had switch places literally and figurately, as Mayfield took up residence in Ibiza, and Carew moved into Mayfield's home in the Cantonments section of the Accra suburbs. The home was a multi-room bungalow, that was possibly one of the prefabricated homes that Padmore had negotiated far back in 1951 to set the tone of infrastructure development and expand opportunities for investment in the Gold Coast. Carew felt guilty about living in a lavish home owned by the government and moved into the stewards' quarters, a small two-room cottage on the property.

Assessing the Cantonments area, Carew saw that upon independence the new African elites in Ghana had taken over and become Blackface copies of their former colonial masters so much so that locals referred to them as "Afro-Saxons." 544 This corruption had been festering in Ghanaian society dating back to the late 1950s as signs of mismanagement, espionage and bribery began to circulate amongst the new Ghanaian petit bourgeoisie. In addition to the yacht parties, Mercedes Benzes, corruption had consumed the Ghanaian government as well as the CPP, the largest corruption scandal of

\footnotetext{
${ }^{544}$ Carew. Episodes in My Life. (2015), 218.
} 
the era had been the purchasing of a $£ 3,000$ golden bed by Mary Edusei, the wife of a senior CPP minister in London, Krobo Edusei. ${ }^{545}$ Echoing Makonnen notion of the “colonial mentality” that pervaded Ghanaian society, Carew's observation placed on display historian, Terence Ranger's, argument that European invented traditions were vital in the creation of the new educated African bourgeoisie in the 1950s and 1960s that would outdo colonial whites in their dedication and loyalty to these traditions. ${ }^{546}$

These observations by Carew were foreseen by George Padmore, Nkrumah's Advisor on African Affairs, before his death. Padmore witnessed the corruption and the factions of resistance to Nkrumah's political ideologies and objectives for the future of Ghana and Africa, and advised Nkrumah on the necessity of imposing a "transition period of a "benevolent dictatorship." For Padmore, this temporary dictatorship was essential since there was "so much mess to be cleaned up that no other way but the strong government" could complete the task. ${ }^{547}$ This notion of strong government was derived from Padmore and Nkrumah's commitment to socialism and the model of the Soviet Union as a modern socialist nation. As one of Nkrumah's closest advisors since 1945, Padmore impressed upon him the necessity of a strong government that could 'direct' development and mobilize resources in Ghana. Unfortunately, along with the progress that resulted from Nkrumah's benevolent dictatorship, came press censorship, the implementation of the repressive legislature to eliminate opposition, accusations of

\footnotetext{
${ }^{545}$ Gaines. American Africans in Ghana. (2012), 154.

${ }^{546}$ Ranger. "The Invention of Tradition In Colonial Africa," in Perspectives on Africa: A Reader in Culture, History, and Representation, edited by Roy Richard Grinker and Christopher B. Steiner, 597-612. (Oxford: Blackwell, 1997)

${ }^{547}$ James. George Padmore and Decolonization from Below. (2014), 167.
} 
embezzlement, and voter manipulation in nationwide elections that resulted in the further consolidation of power within a single-party government.

Although the CPP was organized around the principle of "democratic centralism," in practice, it became less evident as Nkrumah gradually consolidated power with himself. The democratic aspect of this principle faded, as decisions were increasingly handed down from Nkrumah for implementation. ${ }^{548}$ As appointed party officials were imposed on members and used as subservient tools to manipulate the populace, it became clear that the "one man, one vote, one nation" democracy espoused by the CPP had been sacrificed for national "unity" and under the guise of Nkrumah's whimsical decisions and policies. In essence, the shift was merely a movement towards concentration of power with the CPP and ultimately the personal dictatorship of Nkrumah.

Before Carew arrived in Ghana, Nkrumah and the CPP began promoting the idea of, single-party government, which had been in Nkrumah's plans since becoming President in $1960 .^{549}$ In October 1962, the Ghanaian National Assembly unanimously accepted and sealed the motion calling for the introduction of a one-party system of government for Ghana. This was justified by the claim that "there should be in the State One all-embracing political movement or party which will serve as the principal guide for the people's leader and representative in their governmental duties." ${ }^{550}$ As a result, the influence of the Russian model of centralized governance was apparent as Nkrumah and the CPP were successful in implementing a single-party government system, arguing that, as a young state, Ghana could not afford to dispute its national efforts through the

\footnotetext{
${ }^{548}$ Boateng. The Political Legacy of Kwame Nkrumah. (2003), 35.

549 “One Party System Good - Nyerere." Accra Evening News, March 11, 1960, 1.

550 “One Party, One Leader," Accra Evening News, September 13, 1962, 5.
} 
senseless wrangling brought through political opposition and it contended it was through opposition parties that colonialism and imperialism sought to perpetuate their hold on Ghana. ${ }^{551}$ Thus, the one-party system was proclaimed as the truest form of democracy, while multiparty governance was denounced as the chief cause of subversion within Ghana. ${ }^{552}$ By February 1964, the CPP government posed a Referendum on the proposed one-party state. In its reporting of the voting result, the state-owned newspaper, the Accra Evening News, foreshadowed the nature of the new single-party system.

Along with charges of a coming dictatorship, came accusations of voter manipulation, as the Evening News's coverage of the 1964 Referendum reported a $100 \%$ majority vote for the one-party system in several constituencies. It even went so far as to claim that in Sekondi and Ashanti regions, there was reportedly not a single 'no' vote recorded. ${ }^{553}$ This result proved especially suspicious because the Ashanti region was a primary site of resistance to Nkrumah and the CPP since the early 1950s. Furthermore, voter anonymity had also been precluded, as voters were given slips numbered according to their numbers on the electoral roll, which allowed for the identities of voters to potentially be traced by party officials for retaliation. ${ }^{554}$ Fear of such retaliation, particularly in the Sekondi-Takoradi area was warranted considering Nkrumah's handling of overt opposition three years earlier.

In September 1961 a general strike in the Sekondi-Takoradi region sparked a nationwide worker's demonstration in response to widespread worker disillusionment with the Ghanaian government and the nation declining economy. In response to the

\footnotetext{
${ }^{551}$ Ibid.

552 Ahlman. Living with Nkrumahism. (2017), 156.

${ }^{553}$ Jones, Ghana's First Republic. (1976), 86.

${ }^{554}$ Ibid., 87.
} 
failures of the Second Development Plan, rising corruption amongst government officials, and serious economic grievances including falling wages, rising prices, and a government-imposed five percent compulsory saving deduction, railway and dockworkers in the Sekondi-Takoradi area launched a 17-day strike that quickly spread across the nation to include the masses of commercial employees, civil servants, and market women throughout Ghana. ${ }^{55}$ In response to the strike, Nkrumah returned from a two-month peace mission to Russian and China and deployed the 1958 Preventative Detention Act, to deem the strikers as a threat to national security and imprison over 50 strike leaders for four years. ${ }^{556}$ This moment has been viewed as the turning point of the Nkrumah regime, as the strike was viewed as an overt rebuke of the CPP government. ${ }^{557}$ As a result, the Sekondi-Takoradi General Strike was a reflection of the Ghanaian masses' disillusion with Nkrumah and the CPP government, which had become corrupt and unresponsive to the needs and interests of Ghanaian workers.

Since the government deemed the Sekondi-Takoradi strike as an attempt to overthrow the government, soon thereafter, a Criminal Procedure Amendment Bill was passed, establishing a special court to try political offenses with judges appointed by Nkrumah, and with no appeal against their judgments. ${ }^{558}$ Continuing to concentrate political power with himself, Nkrumah ultimately responded to the people's complaints of wage deductions and lack of genuine worker control of the workplace by

\footnotetext{
${ }^{555}$ Robert Fitch and Mary Oppenheimer. Ghana; End of an Illusion. (New York: Monthly Review Press, 1966), 102.

${ }^{556}$ The Preventative Detention Act empowered the CPP government to arrest and detain Ghanaian citizens for up to five years without trial merely for being suspected of or found acting in a manner prejudicial to the defense of Ghana or to state security., "Preventive Detention Act 1958." Dabu Gizenga Collection On Kwame Nkrumah box , 128-17, folder. 374; Boateng. The Political Legacy of Kwame Nkrumah. (2003), 93.

${ }^{557}$ Ahlman. Living with Nkrumahism. (2017), 139.

558 "Crimes against State bill to be introduced soon.” Accra Evening News, September 30, 1961, 12.
} 
compromising the integrity of the nation's legal system. Nkrumah took this further in January 1963, when he formed a Special Criminal Division of the High Court with Nkrumah serving as chief justice along with two other judges appointed by Nkrumah himself. ${ }^{559}$ This Special Criminal Division of the High Court was created to hear cases of treason, sedition, rioting and unlawful assembly, from which there could be no appeal to the outcome. ${ }^{560}$ Nkrumah was empowered to, "in the state's interest," set aside verdicts reached through majority opinions in the Special Criminal Division and order a re-trial. ${ }^{561}$ Also, as a High Court judge, Nkrumah now had the power to pass judgment on those suspected of orchestrating the recent assassination attempts on his life.

In order to legitimize this Special Criminal Division and more importantly to uphold the appearance of democracy, Nkrumah and the CPP dominated government included a Judiciary Amendment to the nation's constitution as a provision in the 1964 Referendum. In addition, as part of the 1964 Referendum, the Evening News once again reported that the Ghanaian people had approved the constitutional amendment giving him the "power to remove from office a judge of the Supreme or High Court or reasons which appear to him sufficient." ${ }^{\text {662 }}$ Similar to Nkrumah's whimsical use of preventative detention in the Sekondi-Takoradi General Strike, this amendment reflected Nkrumah's complete control over Ghana's judicial system, as it now operated in accordance not with the law itself but primarily with the program of the state. Thus by 1964 Nkrumah had

\footnotetext{
559 “Attorney General to Start Proceedings.” Accra Evening News, January 12, 1963, 1.

560 Omari. Kwame Nkrumah, The Anatomy of an African Dictatorship. (New York: Africana Publishing Corporation, 1970), 92.

${ }^{561}$ Jones, Ghana's First Republic, 138.

562 "The Party is victorious," Accra Evening News, February 1, 1964, 3.
} 
secured a one-party government with his party in complete control of the state, he had the power to imprison and prosecute any opposition to his government.

These developments were not lost on the international community, whose eyes had been fixated on Ghana and Nkrumah since March 1957. Shocked by the news of the creation of the Special Criminal Division in Ghana, Nkrumah's mentor from his days as a student at Lincoln University, C.L.R. James, stated: "You can poison a Chief Justice: [but] you cannot dismiss him for a decision from the Bench... By this single act, Nkrumah prepared the population for the morals of the Mafia." ${ }^{" 563}$ Following Nkrumah's dismissal of the Chief Justice for a decision given from the bench, James ended an over twenty years of association with the Ghanaian President. He could no longer publicly support Nkrumah or the CPP, which had effectively destroyed constitutionalism in Ghana.

James' comments reflected not only his own disappointment with the trajectory of Nkrumah's Ghana but also that of many of the recent nations to gain independence, particularly in Carew and Makonnen's homeland of British Guiana. In a February 1964 issue of the Evening Post, a Guianese daily newspaper, it was stated that Nkrumah had shown himself to be of the ordinary breed of $20^{\text {th }}$ century destroyers of democracy, a little carbon-copy Hitler. I am shocked to and shamed to see that democracy cannot survive in Negro hands!"564 Noting that Nkrumah had dismissed a Chief Justice; abolished habeas corpus with the preventive detention act; outlawed all opposition and declared a oneparty state; jailed his opposition leaders including J.B. Danquah; and seemingly

\footnotetext{
${ }^{563}$ Manning Marable. African and Caribbean Politics: From Kwame Nkrumah to Maurice Bishop. (London: Verso, 1987), 136.

564 “Nkrumah - A Littler Carbon-Copy Hitler." Evening Post, February 11, 1964, 6. Walter Rodney National Archives of Guyana.
} 
compromising the notion of free elections, the Evening Post declared that "The first free African Dominion has returned to the jungle. Democracy lies dead there, slaughtered by her Osagyefu." 565

In response to a peace mission sent by Nkrumah to British Guiana to quell the violence being waged between the racially divided political parties of Cheddi Jagan (Indo-Guianese) and Forbes Burnham (Afro-Guianese), it was said that the Ghanaian mission "can only advise on matters concerning a dictatorship, a police state and suppression of rights, but they are incapable of advising on matters of peace and goodwill."566 As the world looked on at the nation and man that held the hopes of the entire African world, it was now apparent that both Ghana and Nkrumah were on a crash course. By 1966, his dictatorship had been neither temporary nor benevolent, and with the nation in social decay, the economy in the brink of collapse, and aspirations to become harbinger of peace in the emergent Cold War, Nkrumah was faced with the threat of a military overthrow.

\section{A Final Meeting With Nkrumah}

Nkrumah seeing himself as a peacemaker, believed that as a non-aligned President of an African nation, he could act as a disinterested and effective intermediary as the cold war rage on between the East and the West. In 1966, during the height of the Vietnam War, Nkrumah decided that it was the proper time to set out on a peace mission to Moscow, Peking, and Hanoi. Carew, in what was destined to be his last meeting with Nkrumah recalled that he advised the President that while the idea of a peace mission was

\footnotetext{
565 Ibid.

566 “Ghana Mission Only Know About A Police State,” Evening Post, February 13, 1964, 5. Walter Rodney Archives.
} 
a good one, he should seriously consider postponing his trip as the timing could not be worse. Facing Carew from behind his large desk and with a large portrait of Lenin behind him, Nkrumah asked belligerently, “Tell me something, were you elected?" He then cut off Carew's reply, declaring "Well, I was elected. I campaigned in every city, town village and hamlet in this motherland of mine, and a majority of my people voted me into office. So what gives you the right to criticize me and my government?"567

Following a long and awkward pause, Carew contended that widespread discontent among the people was on the rise because of the worsening economic situation, and the tensions with the military were at a high due to the military situation in Rhodesia, which Nkrumah appeared reluctant to acknowledge. What is apparent here is that by this point Nkrumah was unable to comprehend the gravity of the domestic situation in Ghana, as a coup was on the horizon. The following sections will explore the causing of the internal strife in Ghana brought on by the dwindling of support for the government and Ghana's Pan-African policy, failed development plans, and the alienation of Ghanaian armed forces.

\section{Losing the People:}

In this final meeting Carew suggested that with a new and even more strict budget coming, the discontent caused by the economic crisis alone could easily transform into rebellion. Nkrumah responded citing the overwhelming support he received at a speech in Black Star Square two weeks prior to commemorate the fifteen-year anniversary of his release from prison in 1951 for promoting illegal nation-wide general strikes, boycotts, and noncooperation with the British colonial government. According to President

${ }^{567}$ Carew. Episodes in My Life. ( 2015), 220. 
Nkrumah, the over half-a-million people in attendance was clear evidence that the people were loyal to him; however, Nkrumah had mistaken the people's silence and the lack of public outrage for loyalty, obedience and support. Nkrumah's suggestion that he had a secure grip on the loyalty of the Ghanaian people reflected a particular disconnect between himself and his citizenship, which he had been ruling over through authoritarian means since the turn of the decade.

It is worth noting that by the mid-1960s partial fruits of Nkrumah's socialist agenda began to manifest. In the industrial sector, the state constructed a major steelworks plant, two sugar refineries, two cocoa refineries, a meat processing plant, a glass factory, and several other enterprises. ${ }^{568}$ Significant achievements were made in education with over a million Ghanaian youth attending primary, middle and secondary schools, while the number of university students had increased to 8,000 by $1966 .{ }^{569}$ There was also an expansion of hospitals and rural health clinics including five new mental hospitals, four urban polyclinics, and six district hospitals by 1966 . In comparison to life under colonial rule, Nkrumah's state represented a qualitative improvement; however, for those who felt neglected in these developments or failed to embrace the socialist ideals of the government in the early 1960s in Ghana, it was not safe to express their dissent.

Furthermore, while the press reported overwhelming majority support for socialism, due to discrepancies in education, literacy, and access to political training in the ideals of socialism, Ghanaian elites were more likely to view socialism as being able

\footnotetext{
${ }^{568}$ Manning Marable and Russell Rickford. Beyond Boundaries, The Manning Marable Reader. (London: Routledge, 2011), 211.

${ }^{569}$ Ibid., 211.
} 
to provide a sense of community and a return to traditional African culture, identity, and social egalitarianism. Whereas, the Ghanaian working masses were more likely to view socialism in Ghana as socialism for the rich since it featured a small percentage of the population receiving high and ever-increasing salaries, the embezzling of public funds, and illicit bribery and corruption within the government. Such views of socialism failed to cultivate a sense of community nor a return to the romanticized egalitarian nature of traditional African societies and culture. Observing these condition in the mid-1960s Julian Mayfield suggests:

[...] most, even among the educated elite, had not the faintest notions of what the word socialism meant. They identified socialism with all of the excesses and corruption of the Government and the Convention People's Party, and they wanted none of it. But fearing prison, they had no outlet for their angry disagreement. Thus, an ugly schism developed between those who were in and those who were out. No dialogue existed between the government and its severest critics. ${ }^{570}$

The CPP's emphasis on discipline, obedience, and vigilance in the workforce became a primary issue as the government attempts to implement socialism never took place on a large scale among the nation's citizenry, whose discontent with the government worsened. By this time any dissent or criticism of the CPP or Nkrumah was believed to be anti-state and based on the one-party state's philosophy, which cast the Nkrumah controlled CPP as a direct representation of Ghana. The result was that all diversity in the larger political discourse had been curtailed as Nkrumaism preached conformity and obedience, and individuals wanting to voice their dissent were forced to consider the economic and social consequences not merely for themselves but their families as well. ${ }^{571}$ Furthermore, since Nkrumah prioritized urban development and

\footnotetext{
570 “Ghana in Perspective," Julian Mayfield Papers, box 13, folder 14.

571 Ahlman. Living with Nkrumahism. (2017), 190.
} 
resources were focused on the southern regions of the nation, the lack of comprehensive results from the development plans represented a failure for the government as the threefourths of Ghana's population in the towns and villages lost farming lands to state-run institutions like the Builders Brigade and state farms. ${ }^{572}$ As a result, the average Ghanaian worker, by the mid-1960s, was incredibly frustrated by the nation's economic and political situation, as rent increased, wages stagnated, and corrupt businessman, police, and government officials routinely feasted on the "fruits of fraud," drinking the finest alcohol, dined on imported food, and drove big cars. ${ }^{573}$

In addition to the failures of Ghanaians to latch onto Nkrumah's vision for a socialist society, several Ghanaian citizens found themselves in direct opposition to Nkrumah's foundational ideology of Pan-Africanism. While the nation was headed for economic crisis it was also providing funding for Nkrumah's Pan-African initiatives. Nkrumah's Pan-African policy, while it sought to give pride and dignity to Ghanaians and Africans as a whole, also devoted considerable resources to Pan-African projects, like the Bureau of African Affairs' funding of African liberation movements for which a $£ 2$ million Consolidated Fund was established. ${ }^{574}$ Some in Ghanaian society came to characterize these initiatives as the fool's errand of "liberat[ing] the whole of Africa." 575 This was also seen in Ghana's hosting of the OAU conference in 1965.

In addition to commissioning the unnecessary construction of the new conference hall for the conference, Nkrumah also instructed the government to fill the nation's shops

\footnotetext{
572 Ibid., 132

573 Ayi Kwei Armah, The Beautiful Ones Are Not Yet Born (Boston: Houghton, 1993), 95, quoted in Ahlman. Living with Nkrumahism. (2017), 145.

574 Dzorgbo. Ghana In Search Of Development. (2017), 179

${ }^{575}$ Ahlman. Living with Nkrumahism. (2017), 131-2.
} 
with imported items so that every African visiting Ghana be made to see the fruits of independence. As a result, many Ghanaians believed that Nkrumah was investing too much in African liberation instead of focusing his resources on properly developing the nation, which caused people to ask: "Why should you give it [money] to African people [outside of Ghana] They should take care of themselves. We should take care of ourselves." 576 Such wasteful spending and large-scale projects were responsible in part for the departure of W. Arthur Lewis in 1959, as he warned about overspending on prestige projects and Nkrumah's Pan-African projects would bankrupt the country. By the mid-1960s, Ghana was well on its way to economic collapse.

\section{Ghana in Economic Crisis:}

Following his 1961 trip to Russia and China, Nkrumah was intent on building a socialist society with a centralized government to direct economic planning through stateowned enterprises. By 1963 Nkrumah chose to abandon his failed development plan after four years and commissioned a new plan to be drawn up. Drawing heavily on the Russian and Chinese models of development and economic planning, the new SevenYear Development Plan for 1964-71 emphasized large scale industrialization and mechanization of agriculture as the foundation of a socialist society. The Seven-Year Development Plan also pledged to deliver old-age insurance for nearly all, free medical services for all, and free education as well as eradicate unemployment. Additionally, the Ghanaian citizenry was promised full stomachs, good homes, postal agencies, day nurseries, better sewage systems and a significant increase in literacy. ${ }^{577}$ Still, from an

\footnotetext{
576 Ibid., 131.

577 “Socialism-Our Goal," Accra Evening News, January 12, 1964, 5.
} 
economic standpoint, the plan was supposed to reorient the economy from the weaknesses of past plans; however, it was never destined to succeed.

The largest hindrance was the sharp decline in cocoa prices on the world market. Although the plan called for greater emphasis on the nation's productivity, this was all contingent on the productivity of a national economy that was overly reliant on its cocoa industry. Unfortunately, between 1959 and 1966, the annual cocoa export earnings totaled $£ 110$ million in losses. ${ }^{578}$ This was felt especially felt by Ghana since the prices of manufactured goods had risen and Nkrumah was still "frantically buying modern goods to modernize," Ghana in his attempt to emulated the Stalinist philosophy of "catch[ing] up with" if not surpassing the advanced nations of the world. ${ }^{579}$ By 1965 the rapid decline and stagnation cocoa prices had disrupted Seven-Year Development Plan, as world market prices fell to $£ 142$ a ton, domestic cocoa harvests had fallen from 580,000 to 410,000 tons a year, and the prices paid to cocoa farmers was at its lowest since the end of World War II. ${ }^{580}$

In addition, the implementation of the plan and its policies were mishandled as projects were wrongly appraised or over-funded, insufficient attention was paid to agricultural production; and with the departure of his conservative Minister of Commerce and Industry, K. A. Gbedemah in 1961, there was no one left to restrain Nkrumah, as the plan projected an excessive $£$ G1 billion in foreign investment. Furthermore, the Bank of Ghana's accounts had fallen to $£ 2.5$ million, Ghana's sterling assets stood at a mere $£ 74$ million, leaving the nation with reserves equivalent to a single month's worth of

\footnotetext{
${ }^{578}$ Dzorgbo. Ghana In Search Of Development. (2017), 181

${ }^{579}$ C.L.R. James. "Why Nkrumah Failed," Encounter, July 1967, 94.

580 "Ghana On Brink of Chaos," The Times, February 25, 1966. Kwame Nkrumah Papers, box 154-41, folder 19.
} 
imports. ${ }^{581}$ As a result, the prospects of this raising this much in foreign investment capital for Ghana, a nation on the brink of bankruptcy, were highly unlikely. Another implication of Gbedemah's resignation was that Nkrumah had begun preparing the budget himself, which resulted in Ghana incurring its largest budget deficits between 1961 and 1965. For example, the 1965 budget expenditure, initially placed at $£ 200$ million, had to be scaled back considerably as cocoa sales had fallen. Finally, exchange reserves were virtually nil and Ghana's export deficit was met by a mass of short-term credit from western companies and the soviet bloc, which were still increasing as Ghana found itself unable to pay its foreign debts on time.

As 1966 approached, Nkrumah visibly looked like a tired man as the pressures of office had taken their toll. With the nation's budget deficit expanding and cocoa prices still in decline, and foreign reserves dwindled down to 500,000 pounds, Nkrumah was forced to acknowledge that he had indeed bankrupt the nation, leading him to shed tears and retreat to his office for a half an hour. ${ }^{52}$ By February 1966, consumer prices were estimated to have risen 75 percent since 1960.583 Ghana's foreign reserve had dried up, external debt was estimated at $£ 120$ million, and with the nation bankrupt major foreign suppliers were reluctant to offer new credit. Additionally, western nations approached by Ghana refused new loans or temporary moratoriums on debt repayments in 1965, particularly because of Nkrumah's ideological and political shift towards socialism and the Eastern bloc. Unfortunately, by the time the IMF/World Bank's recommendations,

\footnotetext{
581 Tignor, Lewis and the Birth of Development Economics. (2006), 191.

582 Biney. The Political and Social Thought of Kwame Nkrumah. (2011), 95.

${ }^{583}$ Dzorgbo. Ghana In Search Of Development. (2017), 181-2.
} 
including an overall diminishing in the state's role in the socioeconomic process, Nkrumah's Pan-African policy had exacerbated tensions with the military.

\section{Alienating the Armed Forces:}

Nkrumah's alienation of the military and the police represented yet another fatal flaw in his final days as his attention on international and Pan-African affairs cause him to overestimate the loyalty of the military apparatus. With African governments being overthrown left and right, the most recent in Nigeria, Carew also warned that the possibility of a coup d'état was a real threat from the regular army. In a final plea to Nkrumah, Carew argued that the soldiers would only obey their officers up until society was being torn to shreds, "and only at that juncture are they likely to turn their guns on their officers and join a popular." Continuing, Carew concluded by reminding Nkrumah that soldiers "will shoot whomever their officers order them to shoot." 584 Nkrumah was reluctant to accept this fact as well, as he called Carew a Judas before dismissing him.

Earlier that month, Nkrumah addressed the National Assembly referencing the uptick in military incursions into the political life of independent African nations. Suggesting military coups were caused not by African life and traditions, but by "the manoeuvres [sic] of neo-colonialism," Nkrumah argued that the most viable defense against military takeovers lay in the one-party system. ${ }^{585}$ It was clear that Nkrumah was severely misjudging the entire nation's dedication to the government. Still, while Carew feared the people would spark a rebellion in Nkrumah's absence, it was with the military

\footnotetext{
${ }^{584}$ Carew. Episodes in My Life. (2015), 221.

585 Jones, Ghana's First Republic. (1976), 269.
} 
and the police that his concerns should have been, as Nkrumah had been alienating them since 1962.

This alienation of the armed forces began in the months following the SekondiTakoradi strike in 1962. A month after the strike was suppressed, Nkrumah was traveling through the countryside and had stopped to greet school children in the northern village of Kulungugu. As he approached the children a bomb exploded about two and a half yards from him, causing Nkrumah to receive extensive shrapnel wounds. A month later a grenade exploded near both Nkrumah's home and his office in Accra. This time it was clear that the malcontents in the nation posed a serious threat to his life and he was facing the threat of violence for the first time since the mid-1950s. In 1964, another assassination attempt came when a policeman shot at him in a point-blank range inside his office building at Flagstaff House, killing the building's chief security guard.

These attacks appeared to affect Nkrumah more mentally than physically as he grew more suspicious of the people around him. The President that once walked among the people daily, now paranoid and concerned for his safety, retreated to the large desk in his office where he conceived of plans to build up his own personal security forces. A number of senior military and police officers were implicated in these attempts, causing Nkrumah to lose trust in the nation's military and police institutions. In 1963, Nkrumah introduced the Security Service Act, which brought several intelligence and military services under his direct control. Three military services were formed after the passing of this act including the Military Intelligence (MI); the Special Intelligence Unit; and the Presidential Detail Department (PDD), which was charged with securing the personal safety of Nkrumah. 
Beyond the troubling notion of creating a personal guard units that were independent of the regular military, Nkrumah's formation of the Special Intelligence Unit demonstrated the persistence ethnic-driven favoritism within Ghanaian society. In the creation of this personal guard, Nkrumah specifically favored the recruitment of Nzima and Fanti men for the Special Intelligence Unit. ${ }^{586}$ With Nkrumah being of Nzima and Fanti descent, his stocking of his personal guard with his kinsmen and men he shared linguistic ties demonstrated the persistence of tribalism within Ghanaian society. This was a common theme throughout the CPP and the Ghanaian government, as Nzima and Fanti men were advanced to lesser positions within the party and in government minister positions. In these instances, tribalism manifested not in the formation political opposition parties based on ethnicity or religion, but from the nation's President himself, which reflected a particular hypocrisy in his political philosophy which stressed a PanAfrican unity and a Ghanaian national identity that transcended ethnic and religious ties. Additionally, the ethnic make-up of the Special Intelligence Unit was not included in his analysis of tribalism that appeared in his 1970 text, Class Struggle in Africa, thus displaying either an imitation or failure a to reflect upon his own contributions to discord in Ghana. ${ }^{587}$

Furthermore, an implication of the 1964 assassination attempt was the creation of the President's Own Guard Regiment (POGR), which served as Nkrumah's own personal army of 1,142 men. ${ }^{588}$ The creation of these parallel institutions further strained the

\footnotetext{
586 Jones, Ghana's First Republic. (1976), 24.

${ }^{587}$ Nkrumah. Class Struggle in Africa. (1970), 59; For more on Tribalism see: Leroy Vail. ed. The Creation of Tribalism in Southern Africa. (Oakland, CA: University of California Press, 1991) and Leonard W. Doob. "From Tribalism to Nationalism in Africa." Journal of International Affairs (1962): 144-155. ${ }^{588}$ Dzorgbo. Ghana In Search Of Development. (2017), 180.
} 
relations with the military and police, as Nkrumah's forces received better quality equipment while the regular armed forces endured shortages. As a result, the regular army considered Nkrumah's creation of the POGR and the PPD to be a direct threat to their existence. ${ }^{589}$ In addition, Nkrumah's Police Service Act of April 1965 caused particular resentment with the police as it gave Nkrumah the authority to appoint and dismiss members of the police force as he saw fit. After dismissing top military officials in 1965 for their suspected involvement in another conspiracy to overthrow the government, Nkrumah, believing himself safe from overthrow, turned attention to the international front. This proved to be a critical oversight with Nkrumah becoming oblivious to the threats brewing within the military, as his attention was wrapped up in the Rhodesia issue.

In one of his final Pan-African initiatives, Nkrumah tried to lead the protests against Rhodesia's Unilateral Declaration of Independence in November 1965, claiming it was a violation of the democratic rights of the Southern Rhodesian authorities. As a result of the declaration, Nkrumah called for African nations to contribute troops for the formation of an African High Command to remove the British backed, illegal, minority regime of South Rhodesia. Nkrumah's diminished influence among his fellow state leaders on the African continent was also demonstrated here as Guinea was the only nation willing to pledge troops to this initiative. With the conflict bringing Ghana and Britain to a showdown, in an emergency session of the National Assembly, the Africa Defense Bill was passed, conferring upon Nkrumah the power to send the nation's forces "wherever the peace and security of Africa is threatened." 590 Shortly thereafter, Nkrumah

\footnotetext{
${ }^{589}$ Biney. The Political and Social Thought of Kwame Nkrumah. (2011), 156

590 Jones, Ghana's First Republic. (1976), 282.
} 
called for volunteers in Ghana for a People's Militia to be sent along with troops to Rhodesia. This according to Lt. Colonel Afrifa of the National Liberation Council, which deposed Nkrumah in February 1966, was the final straw, prompting a coup as military officials believed it criminal and purposeless to dispatch Ghanaian troops and civilians to Rhodesia in an unnecessary war. ${ }^{591}$

\section{Black Midas and the Coup}

Nkrumah was correct in stating that the soldiers would obey their officers; however, it is a wonder as to how he could have misjudged the armed forces and the police after receiving Carew's counsel. This proved to be a grave mistake as the armed forced waited until Nkrumah departed for his peace mission in Hanoi via Peking, on the invitation of Ho Chi Minh, to propose an ending for the war in Vietnam. Carew maintained that his presence would have been better served in Washington D.C. since there were no Vietnamese occupying forces in the United States. ${ }^{592}$ Nonetheless, on Monday, February 21, 1966, Nkrumah departed Ghana for the final time. Carew was not invited to see him off. Two days later the National Liberation Council (NLC) was formed in the northern Ghanaian city of Tamale, where they launched "Operation Cold Chop," the military coup d'état that removed Nkrumah from office. They began their long march south to Accra, sure to bivouac far away from major towns and villages during the day and only making use of the main roads in the early morning hours. ${ }^{593}$ The following day NLC troops surrounded and took the Burma Camp, the headquarters of Ghanaian armed forces located outside of Accra. After capturing the airport, fighting

\footnotetext{
${ }^{591}$ Grilli. Nkrumaism and African Nationalism. (2018), 330

${ }^{592}$ Carew. Episodes in My Life. ( 2015), 234.

${ }^{593}$ Ibid., 236.
} 
broke out when the NLC arrived at the Flagstaff House, where Nkrumah's personal security forces and presidential guards were caught off guard and the compound was swiftly taken.

By six in the morning, the army walked into the radio station and announced in a national broadcast that they had seized power and the nation had been taken over by the National Liberation Council of army and police officers. Eliminating what they called a "One Party dictatorship," the NLC called upon Ghanaian citizens to assist in the arrest of party heads, chairmen, and secretaries of the now-dissolved CPP. Nkrumah's party was caught off guard by the coup, having no contingency plan for mobilizing an armed response, nor a means for alerting the President's Own Guard Regiments of the NLC's presence. Furthermore, most accounts suggest that there was little resistance from the masses and much surprise to the NLC at the popular support for their actions. The rage and frustration of the people were directed not at the NLC, but rather at the leader who had failed them, and with the sycophants and corrupt government officials that had been siphoning off the nation's wealth for their own personal gain. As such, when the NLC seized power, many of the eight hundred people detained in Ghanaian prisons were released; however, over two-thousand people were arrested or placed in "protective custody." Carew and Makonnen would find themselves among this number in the days following the NLC's national broadcast announcing their takeover.

The morning of the coup, Carew went to Geoffrey Bing, Ghana's former Attorney General, to assist with a resistance to the NLC's campaign. For the moment, the concern of Nkrumah loyalists was in getting everyone to safety before the NLC located and detained them. With the coup underway, Carew wrote a letter signed "Black Midas" and 
gave it to Anthony Abrahams, a Jamaican BBC correspondent in Ghana to cover the opening for the Akosombo Hydroelectric Project. Abrahams was flying to England the next day and Carew asked him to deliver the letter to London based Jamaican novelist, Andrew Salkey, who would know what to do. The NLC had been searching for Carew for days; however, he had been staying at the Star Hotel since the outbreak of the coup. Three days into the coup Carew was arrested by the NLC and taken to the upper floors of the Police Headquarters in Accra. As a prisoner at Police Headquarter, he experienced the sole instance in which he recalled being made to feel like an outsider in Ghana.

Once inside Carew was told remove his shirt, shoes, and to lie face down on the floor, as drunken soldiers amused themselves walking across the prisoner's bare backs, some of which were bleeding where they had been pricked with bayonets during their arrests. At this moment, Carew pointed to the men on the floor and declared to the drunk soldiers: "My ancestors left Africa like that, but this time, I intend to leave standing up. If you want me to lie in the slave position you'll have to shoot me." The major, with a malicious smile, replied, "I forgot that you people are descended from slaves, and yet you put on all kinds of airs... A week ago you were lording it over us, and now we're in charge." ${ }^{594}$ The major's response displays a similar sentiment that Padmore and Makonnen experienced from Ghanaians when they were labeled detribalized outsiders with no morals. In the meantime, Abrahams had delivered Carew's message to Salkey in London and a piece ran in the Evening Standard, newspaper reporting on his arrest.

As demonstrations demanding Carew's release commenced in British Guiana, the Guianese newspapers reported on the pre-dawn army coup and the dancing in the streets

\footnotetext{
${ }^{594}$ Ibid., 232.
} 
as Ghanaians tore down Nkrumah self-gratifying statues. ${ }^{595}$ The Guiana Graphic daily newspaper printed the letter Carew had delivered to Andrew Salkey, which read:

"Making bid to leave. Contact BG Commissioner and Prime Minister Forbes

Burnham."596 The letter was signed "Black Midas," which in fact assured Salkey that the message came from Carew. This resulted in a collective from The New World magazine in Guyana cabling Major General Ankrah, head of the NLC military, expressing the grave concern over the safety of the well-known Guyanese author, Jan Carew. ${ }^{597}$

Members of the group requested Carew's safe treatment and early release. Additionally, several West Indians in London wrote to their contacts in Ghana asking for any information on the whereabouts and condition of Carew; however, days since the Carew's letter was published and no word from the NLC had been heard by the Guyanese government or someone inquiring about Carew. ${ }^{598}$

Soon word got back to the new Chief Secretary of the National Liberation Council that the world press had gotten news of Carew's arrest. The international outcry from the Pan-African community that facilitated the passing of messages and various press campaigns demanding Carew's release was a reflection of the Pan-African network that was very much still intact and willing to mobilize for Carew. As a result, Carew as deported to England four days after the NLC caught wind of the international outrage. In that short time, Carew attempted to gather belongings and the contents of his office; however, on his attempt to go to the African Review offices and retrieve what he could but the police confiscated key manuscripts and documents and refused to hand them over,

\footnotetext{
595 “Jubilant crowds swarm streets.” Evening Post, February 24, 1966. Walter Rodney Archives. 596 "Jan Carew 'In Trouble in Ghana?” Guiana Graphic, March 2, 1966. Walter Rodney Archives. 597 “Carew: BG group cables Ankrah.” Guiana Graphic, March 5, 1966. Walter Rodney Archives. 598 “The Riddle of Jan Carew." Guiana Graphic, March 18, 1966. Walter Rodney Archives.
} 
claiming they would forward them to him directly on request. ${ }^{599}$ Furthermore, due to his contract of employment with the Publicity Secretariat, it was stipulated that the Ghanaian government would cover his flight ticket home, and the NLC surprisingly purchased his ticket to London since he was still a British colonial subject.

On March 25, 1966, the Guiana Graphic was able to report that Carew had been released from prison and was now safe in London. As Carew's incarceration was ended, so too was the Pan-African undertaking in Ghana, with the nation in chaos and the former President, once called Africa's "Redeemer," never to return to the nation he loved.

Although Carew's time in the nation was short, his investment in the Pan-African project of Ghana was undeniable. He made an immediate impact in his contributions to the PanAfrican media endeavors of the African Review and service Ghana's media sector as advisor to the Publicity Secretariat. Additionally, while unable to penetrate Nkrumah's sense of reason, Carew, in a time when Nkrumah surrounded himself with sycophants, observed and meritoriously advised him on the imminent threat of rebellion caused by the converging conditions of authoritarianism, economic failures, and Nkrumah's alienation of the Ghanaian people and military.

${ }^{599}$ Carew to Sinclair Clair Drake on October 25, 1967, Jan Carew Papers. 


\section{CONCLUSION: PAN-AFRICANISM AND PRAXIS}

The unit of analysis for this dissertation was the praxis of Pan-Africanism, observed through the prism of West Indian intellectual-activists working in Ghana during the age of decolonization. Through the experiences, ideologies, and observations of these intellectual-activists, this dissertation assessed how Pan-Africanism was practiced in governance as Nkrumah came into power in 1951, began to consolidate power with himself in 1960, and eventually lost power in the coup of February 1966. In doing so it merged the discourses of African history, African diaspora history, and the emergent Black Internationalism paradigm to evaluate the case study of Ghana as a continuation and culmination, of the revitalized Pan-African movement of the post-Italian invasion of Ethiopia era.

The failures of the League of Nations and the major nations of the world to come to Ethiopia's aid in its hour of need, placed the racism of these nations on display for the Black world to see. With another World War on the horizon, the League of Nation's collective inaction demonstrated the Pan-Europeanism the world's major nations, as they were once again able to set aside their differences to agree that Africa was a continent for European domination and exploitation. The message was clear to the intellectuals and activists in Africa and throughout the diaspora, that if African liberation was to be achieved, Blacks could only depend on themselves to secure their freedom. As a result, London became the crucible for the struggle for African liberation and Pan-African organizing in the late 1930, as Blacks in the imperial metropole were forced to form 
alliances across national, ethnic, ideological boundaries, which "would have been unthinkable back home [Africa]." ${ }^{600}$

Following the Manchester 1945 Pan-African Congress, the movement centralized its objectives around African independence and the vision of a unified African continent practicing Pan-Africanism through cooperation between independent nations. Just as $\mathrm{H}$. Sylvester Williams and Marcus Garvey before them, leading this charge were West Indian intellectual-activists like George Padmore, W. Arthur Lewis, and T. Ras Makonnen who had been keeping the transnational networks of Black liberation movements in Africa and the diaspora intact through their work with the International Africa Service Bureau and the Pan-African Federation. As a result, the Pan-Africanism placed on display in London during the 1930s and 1940s was transferred to Ghana, as Nkrumah sought the counsel and expertise of these West Indians in his endeavors to free the Gold Coast and to commence the Pan-African project in Ghana following independence.

\section{Coming to Power:}

By and large, George Padmore had the most extensive influence on Nkrumah's development as an activist, intellectual, and statesman. It was Padmore who facilitated Nkrumah's placement at the fore of the Pan-African movement in London and equipped him with the organizing strategies to build a mass nationalist movement to secure selfgovernment upon his return to the Gold Coast in 1948. Continuing "the Manchester Program" in the Gold Coast, Nkrumah carried on the Pan-African Federation's principle of "Positive Action," to assert the demands of the Ghanaian working masses to the 
British colonial administration. ${ }^{601}$ From London, Padmore also advised Nkrumah on the political strategies to thwart ethnic divisions and violent opposition within the Gold Coast, as well as concept of "Tactical Action," as he negotiated the terms of independence with the British.

One of the reasons Padmore chose to work with Nkrumah in Ghana was because in Ghana he saw a model African nation demonstrating for colonized Black nations in Africa and the diaspora a method for securing their freedom. Upon independence, Padmore oversaw the administration of Ghana's Pan-African Policy of assisting other African liberation movements in securing their own independence. Through his Office of the Adviser to the Prime Minister on African Affairs, Padmore was given complete autonomy and used conferences, media campaigns, and provided direct support to African revolutionary groups to spread Nkrumah's Pan-African ideologies and Ghana's influence with the ultimate goal of establishing a United States of Africa. In Ghana, Padmore found the culmination of his life's work of organizing and linking the PanAfrican and Black International networks across the globe. Additionally, the significance of Padmore's contributions to both Nkrumah and Ghana were canonized in number sites bearing his name, including the George Padmore Research Library of African Affairs and George Padmore Primary School in Tema, which school children attend to this day. Still despite his untimely death in 1959, Padmore left Ghana with a functioning apparatus for administering Ghana's Pan-African Policy, which eventually manifested in the formation of the Bureau of African Affairs.

\section{Consolidation of Power:}

601 Grilli. Nkrumaism and African Nationalism. (2018), 51. 
W. Arthur Lewis's influence on Ghana, was central to Nkrumah's objective of Ghana catching up with the modernized nations of the world. Lewis was a celebrated economist and a Pan-Africanist that possessed the ultimate goal of raising the living standards of the people of under-developed nations. Because of his scholarship, he was sought after to advise on economics in nations throughout the West Indies, South America, Europe, and Asia. However, in the midst of a prolific academic career, Lewis left his positions in academia and the British Colonial Office to work in Ghana, as Nkrumah's Economic Advisor. Charged with placing Ghana on the path to asserting not only its political but its economic independence, Lewis' largest contribution was the Second Economic Development Plan, which carried the weight of expanding Ghana's industrial sector, optimizing agriculture, and inviting foreign capital to spur various development projects.

Unfortunately, the pragmatic and fiscally responsible plan that Lewis constructed for the nation, stood in direct opposition to the rapid development and extravagant prestige projects that Nkrumah had envisioned for the plan. These disagreements eventually led to Lewis' resignation. Accordingly, Nkrumah's gambles on the Second Development Plan resulted in $£ 124$ billion in foreign financial commitments, which the nation was unable to repay as the world prices for cocoa (Ghana's primary source of revenue) plummeted shortly after independence. Some historians have offered up Lewis as the cause of Ghana's economic decline, as the Second Development Plan was attributed solely to his own labor. ${ }^{602}$ However, these suggestions disregard the

602 Douglas Rimmer. Staying Poor: Ghana's Political Economy, 1950-1990. (Oxford: Pergamon Press for the World Bank, 1992), and Tony Killick. Development Economics in Action: A Study of Economic Policies in Ghana. (London: Routledge, 2010.) 
deteriorating relationship between Lewis and Nkrumah, and the president's regular dismissal of sound advice from his economic advisor.

Still, while the plan was far from what he initially proposed, Lewis' commitment to the Pan-African project in Ghana eclipsed his desire to publicly disavow his contributions and openly criticize Nkrumah's nascent authoritarian turn. In his private correspondence Lewis maintained that the Ghanaian government was extremely corrupt and that Nkrumah was not a man of integrity; however, in public discourse he strove to maintain the image of Nkrumah as the preeminent leader of African liberation and characterize his time working in Ghana as highly productive and an overall success. ${ }^{603}$ As such, even with Nkrumah disregarding his advice and making political decisions through non-democratic means, Lewis was conscious of the fact that with African and West Indian nations coming closer to gaining independence, the image of Ghana as a model of Africa nation needed to be maintained.

No other West Indian intellectual-activist was able to closely witness each stage of Nkrumah's political development, from his entrance into the Pan-African movement in London to his removal from power, like T. Ras Makonnen. As a Pan-African revolutionary of the "old guard," Makonnen was called upon to apply his diverse skillsets broadly throughout Ghanaian society from building Pan-African institutions like the African Affairs Centre, African Affairs Committee, to advising on foreign policy with the Bureau of African Affairs, to managing state owned corporations, like State Bakery, Ghana Hotels and Tourism Corporation, and the Guinea Press.

603 Lewis to John D. Esseks March 7, 1968, Lewis Papers, box 5 folder 5; and Lewis to Melvin J. Lasky March 17, 1959, Lewis Papers, box 5 folder 5. 
Staying on for the duration of Nkrumah's tenure in Ghana, Makonnen was able to view Nkrumah's dictatorial turn, which coincided with the increasing influence of the Soviet Union following the death of George Padmore. By the 1960s, Nkrumah had appropriated the centralized Russian model for building a socialist society in Ghana and stressed ideology's ability to raise the living standards of the Ghanaian masses. However, Makonnen observed how Nkrumah's socialism both conflicted with traditional Ghanaian economic systems and fostered a government more interested in state capitalism and overspending on extravagant development plans than actually addressing needs of the masses. Achieving political centralization with a one-party state, and micromanaging nearly every level of governance, Makonnen observed the "power sweet" Nkrumah surrounded by sycophants and corruption permeating throughout the Ghanaian government. Eventually, Makonnen found that dissent and democratic governance were no longer condoned in Ghana as his attempts to counsel Nkrumah on the endemic levels of corruption in Ghana resulted in his swift demotion from Director of the African Affairs Centre to overseeing State Bakeries. Here Makonnen continued to serve loyally because of his dedication to Ghana's Pan-African project. ${ }^{604}$

Loss of Power:

Nkrumah's loss of power was observed firsthand by author, journalist, and activist Jan Carew. Internationally known for his novels Black Midas and Moscow Is Not My Mecca, as well as his Pan-African activism in London, Carew who had come of age on the stories of Padmore and the London Pan-African movement, could not pass on the opportunity to contribute to the Pan-Africanism being practiced in Nkrumah's Ghana.

\footnotetext{
${ }^{604}$ Gaines. American Africans in Ghana. (2012), 195.
} 
Arriving in Ghana fall 1965, Carew's skills were used as he served editor of the African Review magazine and worked in Nkrumah's Publicity Secretariat. He also witnessed Nkrumah's final months in power, which bore a stark difference to the midnight speeches, conferences on Pan-Africanism, images of independence celebrations that had come to characterize Ghana throughout the African diaspora.

The corruption that Makonnen observed had culminated in the locals referring to the new Ghanaian capitalist class and politicians as "Afro-Saxons," in whom they observed ever-increasing salaries, embezzlement of public funds, illicit bribery, and the hoarding of scarce imported resources. ${ }^{605}$ This label conferred upon the elites profiting from the rampant corruption in Ghanaian society was a reflection of the disillusioned Ghanaian working masses who suffered under Nkrumah's Benevolent Dictatorship. Featured in Nkrumah's authoritarian turn was press censorship, Preventative Detention, voter manipulation, Nkrumah's compromising of Ghana's judicial system, and the CPP's one-party government that demanded obedience and characterized any dissent or criticism of the government or Nkrumah as a potential threat to the nation. Subsequently, not only were these policies implemented to further his political objects, they were also necessitated Nkrumah's need to protect himself following a number of failed assassination attempts on his life.

In Ghana, Carew found the open society that once featured Nkrumah walking amongst his people daily, had become a closed society with its president either held up in his office passing down directives to party officials or traveling abroad on international peace keeping missions. From an economic standpoint, by the end of 1965 world cocoa

${ }^{605}$ Carew. Episodes in My Life. (2015), 218. 
prices were still in decline. Consequently, as Ghana's national budget deficit swelled, its foreign reserves originally totaling $£ 150$ million had dwindled down to $£ 500,000$. It was then apparent that Nkrumah's choice to gamble on Ghana's economic future in lieu of heeding Lewis' sound advice in 1959 had resulted the nation essentially going bankrupt.

Further contributing to Nkrumah's recluse and distant disposition was his alienation of the armed forces, which coincided with the implication of senior military and police officers in a number of assassination attempts and conspiracies in the mid1960s. After forming multiple parallel military units for his own personal security, and the passing of legislature expanding Nkrumah's control and authority over the police and the regular army, the military was primed to stage a coup d'état at the opportune moment. Observing these conditions, Carew pled with Nkrumah to postpone his peace mission in Vietnam and refocus his attention on the Ghanaian home front. However, just as with Lewis and Makonnen before him, Carew's sound counsel was dismissed, resulting in Nkrumah's removal from power in February 1966.

\section{Pan-Africanism, Praxis, and Cosmopolitanism}

Whereas other studies of Ghana look at the economics and politics that facilitated Nkrumah's rise and fall, this dissertation has examined the praxis of Pan-Africanism with West Indians in Ghana, as well as the social, economic, and political issues that manifested in Ghanaian society as a result of their presence. With Nkrumah's removal from power, the Pan-African project in Ghana had ended; however, it was apparent that West Indians were extensively involved in directly influencing the trajectory of the nation-building process in Ghana. Just as West Indians were pioneers in the Pan-African 
movement in the early twentieth century, in Ghana Padmore, Lewis, Makonnen, and Carew, were at the helm of the next phase of movement.

In Ghana, a Black government had emerged with a Pan-African leader that declared its independence meant nothing without the independence of the rest of the African continent. Furthermore, from the time he was introduced to the Pan-African movement, Nkrumah possessed as his undeviating aim, the emancipation of the people of Africa; however, he always regarded those in "the West Indies as our brothers, for they have strong ties of kinship with us here in Africa. They, like us, have suffered and are still suffering the inequities of colonial oppression." ${ }^{\prime 606}$ As a result, these Pan-Africanists also viewed Africa's liberation as inextricably linked to decolonization in the West Indies and because of their shared diasporic experience viewed themselves and Africans on the continent as one and the same people.

They were able to adopt this racial essentialism particularly because of their diasporic experience as West Indians. The West Indian identity is predicated on the direct socio-historical implications of trans-Atlantic slavery and colonialism, which cultivated a creolized cultural mix of African, Indigenous, and Asian traits. As a result, West Indian societies were described by Stuart Hall as “by definition cosmopolitan’ since 'everybody who is there came from somewhere else." ${ }^{607}$ This fundamental openness to strangers and difference was a vital dimension of the cosmopolitanism that shapes West Indian identity. It also served as a catalyst to the racial essentialism required for the conceptions of Pan-Africanism in the early twentieth century. As a result, the West

\footnotetext{
606 “Africa's liberation and Unity an Address by Osagyefo.” Dabu Gizenga Collection On Kwame Nkrumah, box 128-19 folder 416/417.

${ }^{607}$ Stuart Hall, and Pnina Werbner. "Cosmopolitanism, Globalisation and Diaspora." in Anthropology and the New Cosmopolitanism, edited by Pnina Werbner, (Oxford: Berg, 2008.), 351.
} 
Indies was a true diasporic society, which cultivated amongst its inhabitants an openness to strangers and a willingness to rely on social networks to engage in migrations throughout the Americas, Europe, and Africa. Most studies of the West Indies including my own - have demonstrated migrations played a key role in the development of West Indian identity, from the intra West Indian slave trade to the patterns of migrant labor that problematized notions of citizenship and identity for West Indians and African Americans in the early twentieth century. ${ }^{608}$

This same negation of stranger hood and openness to difference facilitated the embrace of Pan-Africanism in early twentieth century London as Blacks began flock to Britain. In the British metropole, the diasporic experiences of racial discrimination and colonial subjectivity forced people of African descent to overlook their ethnic and national identities. This resulted in the formation of a Pan-African identity based on their shared experiences and objectives of the liberation of people of African descent regardless of their spatial locales. For Nkrumah, who's political outlook was molded in large part by the influence of West Indians, he understood this cosmopolitan component of Pan-Africanism and sought to implement this in his embrace of the African diaspora in Ghana. However, for West Indians like Padmore, Lewis, Makonnen, and Carew, their status as diaspora blacks and outsiders presented a barrier to the embrace of the PanAfrican project being undertaken in Ghana.

Nkrumah's over site of the significance of ethnic identity and the persistence of tribalism in Ghana, as compared to cosmopolitanism of West Indian identity he observed from his own experiences in the diaspora, presented one of the largest barriers to the

${ }^{608}$ Lara Putnam. Radical Moves: Caribbean Migrants and the Politics of Race in the Jazz Age. (Chapel Hill: University of North Carolina Press, 2013.) 
praxis of Pan-Africanism in Ghana. There existed in Ghana a feeling that the CPP and Ghanaian government possessed too many outsiders. The experiences of Padmore, Lewis, Makonnen, and Carew display a particular aversion to foreign blacks possessing too much influence and power in Ghana. This was demonstrated early on as the issue of Africanization of the Civil Service had become a reoccurring topic of debate in Ghanaian parliament sessions, where it was suggested that continental Africans should be functioning in these position Nkrumah had designated for West Indian Pan-Africanists.

Nkrumah was well aware of what his nation's potential, as well as the nationbuilding skills it lacked. As a result, based on their expertise in various capacities, these West Indian Intellectual-activists were recruited specifically because they possessed a number of skillsets that would further Nkrumah's Pan-African agenda. While Ghana had its own history of anti-colonial organizations and Pan-Africanists, no one in the nation shared the extensive knowledge of Pan-African socialist political philosophy, the experience in Pan-African organizing, nor the international Black activist network of Padmore. Although men from the Gold Coast had been traveling to London to attend universities, Lewis, having taught the first courses on Colonial Economics at London School of Economics and being one of the foremost experts in Development Economics, was brought to Ghana not only to advised Nkrumah on how to spur economic development and industrialization but to also train younger Ghanaian economist to ultimately take his place.

Having developed a strong business acumen with extensive experience in PanAfrican organizing, few other than Padmore possessed the skillsets necessary for organizing the All-African Peoples' Conferences, establishing state institutions like the 
African Affairs Centre, and molding an apparatus to implement Nkrumah's Pan-African policy with the attentiveness and urgency that Makonnen displayed. In the case of Carew, his international notoriety as an author and Pan-African activist with connections throughout the West Indies, Europe, and the United States, made him an ideal candidate for the role of Editor of the African Review. He was also qualified for his role as Nkrumah's advisor to the Publicity Secretariat based on his service in a similar capacity to Cheddi Jagan's government in British Guiana in 1962. As such, the skillsets and expertise of these West Indian Intellectual-activists were at the root of their selection for their service based on Ghana's needs. Furthermore, Nkrumah understood that these men were qualified for their positions based on their past experiences as political strategists, academics, organizers, and editors in the Pan-African movement.

As a result, several Ghanaian ministers, members of parliament, and even CPP members like A.K. Barden, grudgingly accepted these West Indian outsiders. Still as the ecstasy of independence began to fade and economic crisis, social unrest, and authoritarian measures ensued, these West Indian outsiders became the target of envy and a focus of the skepticism within the government. ${ }^{609}$ In spite of providing invaluable advice to Nkrumah as he secured independence, their contributions to nation-building, and in Makonnen's case marrying a Ghanaian woman, these West Indians were still subject to Ghanaian chauvinism, media smear campaigns, and threats of deportation.

Additionally, Nkrumah and his West Indian compatriots, overlooked the magnitude of not only continental and diasporic African divisions, but also the persistence of ethnic divisions within Ghana. This tribalism was a challenge for the

${ }^{609}$ Jones. Ghana's First Republic. (1976), 23. 
duration of Nkrumah's time in power from the founding of the National Liberation Movement in the Ashanti region to thwart the CPP's plans for independence, to the passing of the Avoidance of Discrimination Act (ADA) in December 1957. Nkrumah even engaged in tribalism in his own recruitment of men that shared his Nzima and Fanti ethnic ties for his Special Intelligence Unit following multiple assassination attempts. These ethnic divisions in Ghana demonstrate the shortcomings of broad applications of Benedict Anderson's concept of Imagined Communities, which suggests that the nation and nationalism be regarded as a mode of understanding that constitutes a phenomenon of belonging, comparable to kinship or religion. This ignores the social structures and colonial histories that created the conditions of ethnic sub-nationalism and tribalism in African nations like Ghana. ${ }^{610}$

The predicament of subverting ethnic identity for national identity gives credibility to Samora Machel's assertation that in order "for the nation to live, the tribe must die." ${ }^{611}$ In the case of Ghana, Nkrumah's calls for the immediate embrace of a national Ghanaian identity that transcended ethnic loyalties proved unfeasible as being Ghanaian carried no meaning at the time. Ethnic sub-nationalisms and tribalism were never mitigated by Nkrumah's extensive use of print media, romanticized African history, and calls for both national and continental unity. Ghanaians were able to more readily identify with their familial ethnic ties and the extensive traditions and histories that defined those identities. This resulted in Nkrumah deriding of those that clung to preexisting ethnic identities as tribalists, that were plagued by the remnants of a colonial

\footnotetext{
${ }^{610}$ Benedict Anderson. Imagined communities: Reflections on the Origin and Spread of Nationalism. (Verso Books, 2006.), 5.

${ }^{611}$ Eze, M. The Politics of History in Contemporary Africa. (New York: Palgrave Macmillan, 2010.), 67.
} 
mentality and constituted a potential threat to the nationalist objectives of the Ghanaian government. ${ }^{612}$ In Ghana national consciousness was unable to be formed at the rapid pace that Nkrumah desired. At the time, this made it difficult to cultivate a true sense of Ghanaian nationhood and nationalism, let alone a Pan-Africanism that extended beyond the continent to include all people of African descent.

Prior to independence, notions of Pan-Africanism (continental unity) were reconcilable with African nationalism, as the ideology of African nationalism was less about establishing shared identities and belongingness and more concerned with independence and anti-colonialism. Furthermore, while Nkrumah declared PanAfricanism as a fundamental component of Ghana's political philosophies, these sentiments where not shared by all Ghanaians. This was placed on display in a 1965 session of Ghanaian parliament in which a member expressed the "common view" that:

Many people cannot see our connection with Uganda, Kenya, southern Rhodesia and other states far away. They know Bondouckou is in the Ivory Coast, that is, our immediate neighbour. We know that our people will support us physically and morally, but if they see something in a concrete from, they will be in a better position to pray for unity to come quickly. If we tell them that we are going to have unity with the UAR they ask 'where is it?' If one speaks to them about Morocco or Ethiopia, they ask 'are they in Aburokyiri? (Europe) If one speaks about East Africa they think that is [sic] a far-away place, probably at the end of the world. When our people think of Africa, they think of the man in Bondoukou, Abidjan, Togo and other towns in neighbouring states. ${ }^{613}$

Thus, while Nkrumah's Pan-African rhetoric of continental unity and anti-colonialism was effective in mobilizing national support before independence, by the end of Nkrumah's tenure as President this was no longer the case. By the mid-1960s mmany Ghanaians believed that he was investing too much in Pan-African liberation instead of

${ }^{612}$ Craig Calhoun. "Nationalism and Ethnicity." (Annual review of sociology 19.1 (1993): 211-239.), 218. ${ }^{613}$ Off. Jnl. Parl. Debs., February 15, 1965, col. 1061, quoted in Jones. Ghana's First Republic. (1976), $23-$ 24. 
focusing his resources on properly developing the nation, which caused Ghanaians to ask: "Why should you give it [money] to African people [outside of Ghana] They should take care of themselves. We should take care of ourselves." ${ }^{\prime 614}$ Consequently, as Ghana faced a declining economy and Ghanaians witness the nation funding African liberation movements throughout African and inviting revolutionaries to congregate in Ghana for extravagant conferences, the suggestion of focusing the nation's resources on the domestic front was not an irrational notion.

As such, the praxis of Pan-Africanism in Ghanaian governance and nationbuilding faltered not because of a flaw in the concept of Pan-Africanism, but rather, because Nkrumah moved too quickly in his application of a Pan-African identity to a new nation that needed his attention before the rest of the African world. Had Nkrumah focused his initial energies on developing a strong Ghanaian identity, quelling ethnic divisions in local politics, and ensuring the improved living standards of the Ghanaian people, perhaps then Ghana could have taken the same aggressive approach to spurring Pan-African liberation in Africa. Such an approach may have been reconcilable with the tempered Pan-Africanisms of Lewis and Carew. Conversely, it would have stood in opposition to the radical purist Pan-Africanisms of Padmore and Makonnen, both of whom at the time saw the immediate liberation of African continent as their sole objective.

These diverging notions and applications of Pan-Africanism demonstrate the plurality in conceptions of Pan-Africanism. In order to gain more wholistic understandings of Pan-Africanism and its praxis, it is imperative that scholars consider a

${ }^{614}$ Ahlman. Living with Nkrumahism. (2017), 132. 
number of topics in future studies. The most imperative would be the role and contributions of women to Pan-Africanism. Black women, like Amy Ashwood Garvey, Claudia Jones, and Adelaide Casely Hayford were essential to the Pan-African movement in the Americas, Europe, and Africa. While this dissertation examined the contributions of male West Indian intellectual-activists from the British empire, a limitation manifests in its scarcity of women and gender analyses of the practice of Pan-Africanism in Ghanaian society. This must be addressed in future research.

One of the things that bound Africans and West Indians together in their diasporic experiences was their shared conditions as British colonial subjects. While they shared this condition, the African and West Indian colonial experiences possessed a number of diverging social and political worldviews. These differences would have shaped a number of assumptions that influenced social interactions between Africans and West Indians operating in each other's homelands. Thus, as the discourse on Black Internationalism expands, it must include in depth examinations of the trans-oceanic histories of British colonialism, which exacerbated tensions and stereotypes not only between West Indians and Ghanaians, but also the ethnic sub-nationalisms that furthered the tribalism that caused divisions amongst Africans in their respective nations.

Additionally, future studies of Black Internationalism must continue explorations of the international contexts in which Black social movements took place, as well as the discursive continuity facilitating the transnational transfer of political ideologies, critical analyses, and divergent conceptions of race that influenced these social movements. Finally, Pan-Africanism can no longer be studied merely as a movement, ideology, nor a mobilizing principle for activism. Rather its ultimate political objective, Black self- 
governed nations, must be closely examined in case studies of nations that placed the ideology into practice in governance to assess its achievements and shortcomings.

Thus, while Nkrumah must bear some responsibility for the failures of Ghana, these failures should not be viewed as those of an individual personality. Rather it must be viewed within the contexts of the difficulties of being the first independent SubSaharan African nation attempting to establish a viable government to bring order to the chaos left behind by European colonialism. In spite of his missteps, it would be unwise to discard his accomplishments and significance to the larger African liberation movement. Returning to the Gold Coast in 1948, it took Nkrumah less than a decade to secure independence for his nation. As a result, until this day, the name Kwame Nkrumah, still commands respect and stands as a symbol of African freedom; however, his significance to African liberation movement were underscored by the influence of the West Indians that nurtured his political development in the tradition of Pan-African activism during his time in the African diaspora and as head of state in Ghana.

Following his removal from power, Nkrumah took refuge in Guinea, where he served as Co-President with Sekou Toure. In Guinea, where Nkrumah reflected and wrote about his time in power as well as the future of Africa, his experience with these West Indian intellectual-activists came full circle, as he became a mentor to Trinidadian Black Power intellectual-activist, Kwame Ture. ${ }^{615}$ The now exiled Nkrumah passed on the very principles of Pan-Africanism that he received at Padmore's kitchen table in 1945. In doing so, Nkrumah ensured the future of Pan-Africanism as Ture carried the movement and its revolutionary principles into the twenty-first century.

615 Donald J. McCormack. "Stokely Carmichael and Pan-Africanism: Back to Black Power." The Journal of Politics 35, no. 2 (1973): 388. 


\section{REFERENCES}

\section{Archival Collections in Ghana}

George Padmore Research Library of African Affairs, Accra.

Institute of African Studies, University of Ghana, Legon.

Public Records and Archive Administration Department (PRAAD), National Archives of Ghana, Accra.

\section{Archival Collections in the West Indies}

Eric Williams Memorial Collection, The University of the West Indies, Saint Augustine. Walter Rodney National Archives of Guyana, Georgetown.

\section{Archival Collections in the United States}

C. L. R. James Papers, Rare Book and Manuscript Library, Columbia University Library. Dabu Gizenga Collection On Kwame Nkrumah, The Moorland-Spingarn Research Center, Howard University.

George Padmore Collection, Firestone Library, Princeton University.

Harry Ransom Center, The University of Texas at Austin.

Jan Carew Papers, The Jan Carew Estate, Louisville.

Julian Mayfield Papers, Schomburg Center for Research on Black Culture, New York Public Library, New York City.

Kwame Nkrumah Papers, The Moorland-Spingarn Research Center, Howard University. University of Florida Archives, The University of Florida.

W. Arthur Lewis Papers, Seeley G. Mudd Manuscript Library, Princeton University.

\section{Newspapers, Magazines, and Journals}

Accra Evening News

Africa Special Report

African Affairs Bulletin

African Review

Black World

Encounter

Evening Post

Guiana Graphic

Labour Monthly

League of Coloured Peoples Newsletter

Monthly Report: The Institute of Black World

Negro Worker

Pan-Africa

Présence Africaine

The Keys 
The Spark

The Times

West Africa

\section{Articles, Books, Pamphlets, Dissertations, and Unpublished Manuscripts}

Abrahams, Peter. "Nkrumah, Kenyatte and the Old Order." in African Heritage, edited by Jacob Dracher, 142-3. New York: Crowell-Collier, 1963.

Adi, Hakim. West Africans in Britain 1900-1960: Nationalism, Pan-Africanism and Communism. London: Lawrence \& Wishart, 1997.

. "Pan-Africanism and West African Nationalism in Britain." African Studies Review 43, no. 1 (2000): 69-82.

. Pan-Africanism and Communism: The Communist International, Africa and the Diaspora, 1919-1939. Trenton, NJ: Africa World Press, 2013. . Pan-Africanism: A History. London: Bloomsbury Publishing, 2018.

Adi, Hakim and Marika Sherwood. Pan-African History: Political Figures From Africa and The Diaspora Since 1787. London: Routledge, 2003.

Adom, H. "The Role of Ghana in African Liberation and Unity, 1957-77." PhD dissertation., Temple University, 1991.

Ahlman, Jeffrey S. Living with Nkrumahism: Nation, State, and Pan-Africanism in Ghana. Athens: Ohio University Press, 2017.

Ajayi, J. F. Ade. "The Continuity of African Institutions under Colonialism," in Emerging Themes in African History, edited by Terence O. Ranger, 189-200. London: Heinemann Educational, 1968.

Akyeampong, Emmanuel. Drink, Power, and Cultural Change: A Social History of Alcohol in Ghana, c. 1800 to Recent Times. Portsmouth, NH: Heinemann, 1996. . Between the Sea and the Lagoon: An Eco-Social History of the Anlo of Southeastern Ghana, c. 1850 to Recent Times. Athens: Ohio University Press, 2001.

Albert, Isaac Olawale, and John Edward Phillips. "Data Collection and Interpretation in the Social History of Africa." Writing African History (2005): 287-307.

Alence, Rod. "Colonial Government, Social Conflict and State Involvement in Africa's Open Economies: the Origins of the Ghana Cocoa Marketing Board, 193946." The Journal of African History 42, no. 3, (2001): 397-416.

Allman, Jean Marie, The Quills of the Porcupine: Asante nationalism in An Amergent Ghana. Madison: University of Wisconsin Press, 1993.

Anderson, Benedict. Imagined Communities: Reflections on the Origin and Spread of Nationalism. London: Verso Books, 2006.

Angelou, Maya. All God's Children Need Traveling Shoes. London: Vintage, 2010.

Armah, Kwesi. Peace Without Power: Ghana's Foreign Policy, 1957-1966. Accra: Ghana University Press, 2004.

Asante, Molefi K. Afrocentricity: The Theory of Social Change. Chicago, IL: African American Images, 2003.

Asante, Samuel K.B. Pan-African Protest: West Africa and the Italo-Ethiopian Crisis, 1934-1941. London: Longman Publishing Group, 1977. 
Askew, Kelly. Performing the Nation: Swahili music and Cultural Politics in Tanzania. Chicago: University of Chicago Press, 2002.

Austen, Ralph A. African Economic History: Internal Development and External Dependency. London: James Currey, 1987.

Azikiwe, Nnamdi. Renascent Africa. London: Frank Cass, 1968, originally 1937. . My Odyssey: An Autobiography. New York: Praeger, 1970.

Bateman, Merrill J. "Aggregate and Regional Supply Functions for Ghanaian Cocoa, 1946-1962." Journal of Farm Economics 47, no. 2 (1965): 384-401.

Bay, Edna G., and Kristin Mann, eds. Rethinking the African Diaspora: The Making of a Black Atlantic World in the Bight of Benin and Brazil. London: Routledge, 2013.

Becker, Charles M., and Terry-Ann Craigie. "W. Arthur Lewis in Retrospect." The Review of Black Political Economy 34, no. 3-4 (2007): 187-216.

Bedasse, Monique A. Jah Kingdom: Rastafarians, Tanzania, and Pan-Africanism in the Age of Decolonization. Chapel Hill: University North Carolina Press Books, 2017.

Bernal, Martin. Black Athena: Afroasiatic Roots of Classical Civilization, Volume I: The Fabrication of Ancient Greece, 1785-1985. New Brunswick: Rutgers University Press, 1987.

Biney, Ama. The Political and Social Thought of Kwame Nkrumah. New York: Palgrave Macmillan, 2011.

Blyden, Nemata Amelia. West Indians in West Africa, 1808-1880: The African Diaspora in Reverse. Rochester, NY: University of Rochester Press, 2000.

Boateng, Charles. The Political Legacy of Kwame Nkrumah. Lewiston, NY: Edwin Mellen Press, 2003.

Bourret, Florence Mabel. Ghana, the Road to Independence, 1919-1957. Stanford, Calf.: Stanford University Press, 1960.

Butler, Kim D. "Defining Diaspora, Refining a Discourse." Diaspora: a Journal of Transnational Studies 10, no. 2 (2001): 189-219. . "Clio and the Griot: the African Diaspora in the Discipline of History." in The African Diaspora and the Disciplines, edited by Tejumola Olaniyan and James H. Sweet, 21-46. Bloomington: Indiana University Press, 2010.

Calhoun, Craig. "Nationalism and Ethnicity." Annual Review of Sociology, 19.1 (1993): 211-239.

Carew, Jan. Moscow Is Not My Mecca. London: Secker \& Warburg, 1964. . Ghosts in Our Blood: With Malcolm X in Africa, England, and the Caribbean. New York: Lawrence Hill Books, 1994. . Episodes in My Life: The Autobiography of Jan Carew. Leeds, England: Peepal Tree Press, 2015.

Carew, Joy Gleason. Blacks, Reds, and Russians: Sojourners in Search of the Soviet Promise. Rutgers University Press, 2008. . "Black Midas in Moscow: Conversations with Jan Carew." Small Axe Salon 7, December 2011. http://smallaxe.net/sxsalon/interviews/black-midas-moscow.

Carretta, Vincent, ed. Unchained Voices: An Anthology of Black Authors in the EnglishSpeaking World of the Eighteenth Century. Lexington: University Press of Kentucky, 2013.

Clark, Gracia. "Consulting Elderly Kumasi Market Women about Modernization." Ghana Studies 12, no. 1 (2009): 97-119. 
Clarke, John Henrik. "African-American Historians and the Reclaiming of African History." Présence Africaine 2 (1979): 29-48.

Conyers, James. "Edward Wilmot Blyden and the African Personality: A Discourse on African Cultural Identity." In Racial Structure and Radical Politics in the African Diaspora, edited by G.A. Persons, 151-168. Routledge: New York, 2017.

Cooper, Frederick. "Conflict and Connection: Rethinking Colonial African History." The American Historical Review 99, no. 5 (1994): 1516-1545.

Davidson, Basil. The Liberation of Guinea: Aspects of an African Revolution. Harmondsworth: Penguin, 1969

. Black Star: A View of the Life and Times of Kwame Nkrumah. New York: Praeger, 1974.

Davies, Carole Boyce. Left of Karl Marx: The Political Life of Black Communist Claudia Jones. Durham: Duke University Press, 2007.

Davis, James. Eric Walrond: A Life in the Harlem Renaissance and the Transatlantic Caribbean. New York: Columbia University Press, 2015.

Dei-Anang, M. The Administration of Ghana's Foreign Relations, 1957-1963: A Personal Memoir. London: University of London. 1975.

Dike, K. Onwuka. Trade and Politics in the Niger Delta 1830-1885: An Introduction to the Economic and Political History of Nigeria. Oxford: Oxford University Press. 1956.

Diop, Cheikh Anta. The African Origin of Civilization: Myth or Reality. Chicago, IL: Chicago Review Press, 1989. . Civilization or Barbarism. Chicago, IL: Chicago Review Press, 1991.

Du Bois, William Edward Burghardt and Herbert Aptheker. The Correspondence of WEB Du Bois. Amherst: University of Massachusetts Press, 1997.

Dworkin, Ira. Congo Love Song: African American Culture and the Crisis of the Colonial State. Chapel Hill: University of North Carolina Press, 2017.

Dzorgbo, Dan-Bright S. Ghana in Search of Development: The Challenge of Governance, Economic Management and Institution Building. London: Routledge, 2017.

Edwards, Brent Hayes. "The Uses of Diaspora." Social Text 19, no. 1 (2001): 45-73. . The Practice Of Diaspora: Literature, Translation, and the Rise of Black Internationalism. Cambridge: Harvard University Press, 2009.

Edwards, Nadi. "Diaspora, Difference, and Black Internationalisms." Small Axe 9, no. 1 (2005): 120-128.

Esedebe, Peter Olisanwuche. Pan-Africanism: the Idea and Movement, 1776-1991. Washington (D.C.): Howard University Press, 1994.

Essien, Kwame. Brazilian-African Diaspora in Ghana: The Tabom, Slavery, Dissonance of Memory, Identity, and Locating Home. East Lansing : Michigan State University Press, 2016.

Ewing, Adam. The Age of Garvey: How a Jamaican Activist Created a Mass Movement and Changed Global Black Politics. Princeton: Princeton University Press, 2016.

Eze, M. The Politics of History in Contemporary Africa. New York: Palgrave Macmillan, 2010.

Falola, Toyin and Matthew M. Heaton. A History of Nigeria. Cambridge: Cambridge University Press, 2008.

Falola, Toyin. Nationalism and African Intellectuals. New York: University Rochester 
Press, 2001.

Fitch, Robert and Mary Oppenheimer. Ghana; End of an Illusion. New York: Monthly Review Press, 1966.

Fuller, Gavin. The Telegraph Book of Readers' Letters from the Great War. London: Aurum Press Limited, 2014.

Fuller, Harcourt. Building the Ghanaian Nation-State: Kwame Nkrumah's Symbolic Nationalism. New York: Palgrave Macmillan, 2014.

Gaines, Kevin K. American Africans in Ghana: Black expatriates and the Civil Rights Era. Chapel Hill: University of North Carolina Press, 2012.

Germain, Félix F. Decolonizing the Republic: African and Caribbean Migrants in Postwar Paris, 1946-1974. Lansing: Michigan State University Press, 2016.

Gilroy, Paul. The Black Atlantic: Modernity and Double Consciousness. Cambridge: Harvard University Press, 1993. . There Ain't No Black in the Union Jack. London: Routledge, 2013.

Grant, Nicholas. Winning Our Freedoms Together: African Americans and Apartheid, 1945-1960. Chapel Hill: University of North Carolina Press, 2017.

Grilli, Matteo. Nkrumaism and African Nationalism. New York: Palgrave Macmillan, 2018.

Gupta, R.S. Imperialism and the British Labour Movement 1914-1964. London: Macmillan, 1974.

Guridy, Frank Andre. Forging Diaspora: Afro-Cubans and African Americans in a World of Empire and Jim Crow. Chapel Hill: University of North Carolina Press, 2010.

Hadjor, Kofi Buenor. Nkrumah and Ghana. Trenton, NJ: Africa World Press, 2003.

Hall, Stuart and Pnina Werbner. "Cosmopolitanism, Globalisation and Diaspora," 345-60. in Anthropology and the New Cosmopolitanism, edited by Pnina Werbner, Oxford: Berg, 2008.

Harris, Joseph E., ed. Global Dimensions of the African Diaspora. Washington (D.C.): Howard University Press, 1993.

. African-American Reactions to War in Ethiopia, 1936-1941. Baton

Rouge: Louisiana State University Press, 1994.

Hooker, James R. Black Revolutionary; George Padmore's Path From Communism To Pan-Africanism. New York: Praeger, 1967.

Howell, Thomas A., and Jeffrey P. Rajasooria, eds. Ghana and Nkrumah. New York: Facts on File, Incorporated, 1972.

Inikori, Joseph E. Africans and The Industrial Revolution In England: A Study In International Trade and Economic Development. Cambridge: Cambridge University Press, 2002.

Jackson, John G. Introduction to African Civilizations. Mansfield Centre, CT : Martino Publishing, 2015.

James, Cyril Lionel Robert. Nkrumah and the Ghana Revolution. Westport, Conn: Lawrence Hill \& Company, 1977. . A History of Pan-African Revolt. Oakland, Calif: PM Press, 2012. James, Leslie. George Padmore and Decolonization From Below: Pan-Africanism, the Cold War, and the End of Empire. New York: Palgrave Macmillan, 2014. . "Transatlantic Passages: Black Identity Construction in West African and West Indian Newspapers, 1935-1950." in African Print Cultures: Newspapers and 
Their Publics in the Twentieth Century, edited by Peterson, Derek, Steph Newell, and Emma Hunter, 49-74. Ann Arbor: University of Michigan Press, (2016).

James, Winston, and Clive Harris, eds. Inside Babylon: The Caribbean Diaspora in Britain. London: Verso, 1993.

James, Winston. Holding Aloft the Banner Of Ethiopia: Caribbean Radicalism In Early Twentieth-Century America. London: Verso, 1998.

. "Explaining Afro-Caribbean social mobility in the United States: beyond the Sowell thesis." Comparative Studies in Society and History 44, no. 2 (2002): 218262.

Jones, Trevor. Ghana's First Republic 1960-1966: The Pursuit of The Political Kingdom. London: Methuen \& Co Ltd., 1976.

Kelley, Robin DG. "“But a Local Phase of a World Problem”: Black History's Global Vision, 1883-1950." The Journal of American History 86, no. 3 (1999): 10451077.

. Freedom Dreams: The Black Radical Imagination. Boston: Beacon Press, 2002.

Langley, J. Ayodele. Pan-Africanism and Nationalism in West Africa, 1900-1945: A Study in Ideology and Social Classes. Oxford: Clarendon Press, 1973.

Legum, Colin. Pan-Africanism. London: Pall Mall Press, 1962

Lentz, Carola. "'Tribalism' and Ethnicity in Africa." Cah. Sci. hum 31.2 (1995): 303328.

Lewis, W. Arthur. "The Case of the West Indies." Labour in the West Indies: The Birth of a Workers' Movement, 1939.

. The Principles of Economic Planning: A Study Prepared for the Fabian Society. London: George Allen \& Unwin Ltd, 1949.

. "Economic Development with Unlimited Supplies of Labour." The Manchester School 22, no. 2 (1954): 139-191.

. Theory of Economic Growth. Homewood, Ill., 1955.

. "Unemployment in Developing Countries." The World Today 23, no. 1 (1967): $13-22$.

. "The Sveriges Riksbank Prize in Economic Sciences in Memory of Alfred Nobel 1979," NobelPrize.org, accessed April 21, 2020, https://www.nobelprize.org/prizes/economic-sciences/1979/lewis/biographical/.

Lonsdale, John. " Moral Ethnicity and Political Tribalism." Occasional Paper 11 (2014): 131-150.

Luise White. The Comforts of Home: Prostitution in Colonial Nairobi. Chicago, IL: University of Chicago Press, 2009.

Maddox, Gregory H. James L. Giblin, and Isaria N. Kimambo, eds. Custodians of the Land: Ecology and Culture in the History of Tanzania. Athens: Ohio University Press, 1996.

Mahler, Anne Garland. From the Tricontinental to the Global South: Race, Radicalism, and Transnational Solidarity. Durham: Duke University Press, 2018.

Makalani, Minkah. In the Cause of Freedom: Radical Black Internationalism from Harlem to London, 1917-1939. Chapel Hill: University of North Carolina Press, 2011.

Makonnen, Ras. Pan-Africanism From Within. Nairobi; New York: Oxford University Press, 1973. 
Manning, Patrick. "Africa and the African Diaspora: New Directions of Study." Journal of African History, 44 (2003): 487-506.

Marable, Manning and Russell Rickford. Beyond Boundaries, The Manning Marable Reader. London: Routledge, 2011.

Marable, Manning. African and Caribbean Politics: From Kwame Nkrumah to Maurice Bishop. London: Verso, 1987.

Markakis, John. "Nationalism and Ethnicity in the Horn of Africa." in Ethnicity and Nationalism in Africa, edited by P.Yeros, 65-80. London: Palgrave Macmillan UK, 1999.

Markle, Seth. A Motorcycle on Hell Run: Tanzania, Black Power, and the Uncertain Future of Pan-Africanism, 1964-1974. East Lansing: University of Michigan Press, 2017.

Martin, Tony. The Pan-African Connection: From Slavery to Garvey and Beyond. Dover, Mass.: The Majority Press, 1984.

Matera, Marc. Black London: The Imperial Metropolis and Decolonization in The Twentieth Century. Oakland, CA: University of California Press, 2015.

Mazrui, Ali, Kwame Nkrumah and A. A. Afrifa. "Towards a Pax Africana." Science and Society 33, 1 (1969): 101-104.

Mazrui, Ali Al'Amin, and Michael Tidy. Nationalism and New States in Africa: from about 1935 to the Present. Nairobi: Heinemann, 1984.

McCain, James A. "Attitudes toward Socialism, Policy, and Leadership in Ghana." African Studies Review 22, no. 1 (1979): 149-169.

McCormack, Donald J. "Stokely Carmichael and Pan-Africanism: Back to Black Power." The Journal of Politics 35, no. 2 (1973): 386-409.

McDougal, Serie. Research Methods in Africana Studies. New York, NY: Peter Lang, 2014.

Meredith, David. "The Colonial Office, British Business Interests and the Reform of Cocoa Marketing in West Africa, 1937-1945." Journal of African History (1988): 285-300.

Meriwether, James Hunter. Proudly We Can Be Africans: Black Americans and Africa, 1935-1961. Chapel Hill: University of North Carolina Press, 2002.

Milburn, Josephine Fishel. "The Fabian Society and the British Labour Party." Western Political Quarterly 11, no. 2 (1958): 319-339.

Mine, Yoichi. "The Political Element in the Works of W. Arthur Lewis: The 1954 Lewis Model and African Development." The Developing Economies 44, no. 3 (2006): 329-355.

Morrison, Minion KC. Ethnicity and Political Integration: The Case of Ashanti, Ghana. Syracuse, NY: Syracuse University Facs Publications, 1982.

Munro, John. The Anticolonial Front: The African American Freedom Struggle and Global Decolonization, 1945-1960. Cambridge: Cambridge University Press, 2017.

Nkrumah, Kwame. Ghana: The Autobiography of Kwame Nkrumah. New York: Nelson, 1957.

. Towards Colonial Freedom. London, Heinemann, 1962.

. Class Struggle in Africa. London: Panaf Books, 1970.

. Consciencism. New York: New York University Press, 1970. 
Northrup, David. Africa's Discovery of Europe. Oxford: Oxford University Press, 2013.

Okpewho, Isidore, Carole Boyce Davies, and Ali Al'Amin Mazrui, eds. The African

Diaspora: African Origins and New World Identities. Bloomington: Indiana University Press, 2001.

Olaniyan, Tejumola, and James Hoke Sweet, eds. The African diaspora and the Disciplines. Bloomington: Indiana University Press, 2010.

Olwig, Karen Fog. "Cosmopolitan Traditions: Caribbean Perspectives." Social Anthropology 18, no. 4 (2010): 417-424.

Omari, T. Peter. Kwame Nkrumah: The Anatomy of An African Dictatorship. New York: Africana Publishing Corporation, 1970.

Osei-Nyame, Kwadwo. "Pan-Africanist ideology and the African Historical Novel of SelfDiscovery: the Examples of Kobina Sekyi and JE Casely Hayford." Journal of African Cultural Studies 12, no. 2 (1999): 137-153.

Padmore, George. Africa: Britain's Third Empire. London: D, Dobson, 1949. . The Gold Coast Revolution: The Struggle of An African People From Slavery to Freedom. London: D, Dobson, 1953.

. Pan-Africanism or Communism. Garden City, NY: Anchor Books, 1971.

. The Life and Struggles of Negro Toilers. Hollywood, Calif., Sun Dance Press, 1971.

. Africa and World Peace. London: Routledge, 2019.

Pankhurst, Richard. "Italian fascist war crimes in Ethiopia: A history of their discussion, from the League of Nations to the United Nations (1936-1949)." Northeast African Studies 6, no. 1/2 (1999): 83-140.

Peterson, Derek, Steph Newell, and Emma Hunter. African Print Cultures: Newspapers and Their Publics in the Twentieth Century. Ann Arbor: University of Michigan Press, 2016.

Plummer, Brenda Gayle. Rising Wind: Black Americans and US Foreign Affairs, 19351960. Chapel Hill: University of North Carolina Press, 1996.

. In Search of Power: African Americans in the Era of Decolonization, 1956-1974. Cambridge: Cambridge University Press, 2013.

Poe, Daryl Zizwe. Kwame Nkrumah's Contribution to Pan-African Agency: An Afrocentric Analysis. New York: Routledge, 2003.

Polsgrove, Carol. Ending British rule in Africa: Writers in a Common Cause. Manchester: Manchester University Press, 2017.

Polyné, Millery. From Douglass to Duvalier: US African Americans, Haiti, and Pan Americanism, 1870-1964. Gainesville: University Press of Florida, 2010.

Potkay, Adam and Sandra Burr, eds., Black Atlantic Writers of the 18th Century. New York: Palgrave Macmillan, 1995.

Prah, Kwesi Kwaa. Beyond the Color Line: Pan-Africanist Disputations: Selected Sketches, Letters, Papers, and Reviews. Trenton, NJ: Africa World Press, 1998.

Putnam, Lara. Radical Moves: Caribbean Migrants and the Politics of Race in the Jazz Age. Chapel Hill: University of North Carolina Press, 2013.

Rabaka, Reiland. The Negritude Movement: WEB Du Bois, Leon Damas, Aime Cesaire, Leopold Senghor, Frantz Fanon, and the Evolution of an Insurgent Idea. Lanham, Maryland: Lexington Books, 2015.

Rahman, Ahmad. The Regime Change of Kwame Nkrumah: Epic Heroism in Africa and 
the Diaspora. New York: Palgrave Macmillan, 2007.

Ramdin, Ron. The Making of The Black Working Class in Britain. London: Verso Books, 2017.

Ranger, Terence. "The Invention of Tradition in Colonial Africa." in Perspectives on Africa: A Reader in Culture, History, and Representation, edited by Roy Richard Grinker and Christopher B. Steiner, 597-612. Oxford: Blackwell, 1997.

Rathbone, Richard. "The Transfer of Power and Colonial Civil Servants in Ghana." The Journal of Imperial and Commonwealth History 28, no. 2 (2000): 67-84. . Nkrumah \& the Chiefs: The Politics of Chieftaincy in Ghana, 1951-60. Athens: Ohio State University Press, 2000.

Ray, Carina E. Crossing the Color Line: Race, Sex, and the Contested Politics of Colonialism in Ghana. Athens: Ohio University Press, 2015.

Republic of Ghana, Ministry of Information and Broadcasting. Nkrumah's Subversion In Africa: Documentary Evidence of Nkrumah's Interference In The Affairs of Other African States. Accra: Ministry of Information and Broadcasting, 1966.

Robinson, Cedric J. Black Marxism: The Making of the Black Radical Tradition. Chapel Hill: University of North Carolina Press, 2000.

Rodney, Walter. How Europe Underdeveloped Africa. Dar es Salaam: Tanzania Publishing House, 1972.

Schmitt, Carl. The Concept of the Political: Expanded Edition. Chicago: University of Chicago Press, 2008.

Schwarz, Bill. West Indian Intellectuals in Britain. Manchester: Manchester University Press, 2003.

Sharpley-Whiting, T. Denean. Bricktop's Paris: African American Women in Paris between the Two World Wars. Albany, NY: Suny Press, 2015.

Sherwood, Marika. Kwame Nkrumah: The Years Abroad 1935-1947. Legon, Accra, Ghana: Freedom Publications, 1996.

. "George Padmore and Kwame Nkrumah: A Tentative Outline of Their Relationship." in George Padmore: Pan-African Revolutionary, edited by Fitzroy Baptiste and Rupert Lewis, 162-82. Kingston: Ian Randle, 2009.

. Origins of Pan-Africanism: Henry Sylvester Williams, Africa, and the African Diaspora. London: Routledge, 2012.

Solomon, Mark. The Cry Was Unity: Communists and African Americans, 1917-1936. Jackson: University Press of Mississippi, 1998.

Soyinka, Wole. An Economic History of Ghana: Reflections on A Half-Century of Challenges \& Progress. Osu, Accra, Ghana: Ayebia Clarke Pub Limited, 2008.

Stephens, Michelle. "Disarticulating Black Internationalisms: West Indian Radicals and The Practice of Diaspora." Small Axe 9, no. 1. (2005): 100-111. . Black Empire. Durham: Duke University Press, 2005.

Stephens, Ronald Jemal and Adam Ewing, eds. Global Garveyism. Gainesville: University Press of Florida, 2019.

Stevens, Margaret. Red International and Black Caribbean: Communists in New York City, Mexico and the West Indies, 1919-1939. Chicago: University of Chicago Press, 2017.

Schwarz, Bill. West Indian Intellectuals in Britain. Manchester: Manchester University Press, 2003. 
Talton, Benjamin. Politics of Social Change in Ghana. New York: Palgrave Macmillan, 2010.

Tashjian, I. and Jean Allman. 'I Will Not Eat Stone. 'A Women's History of Colonial Asante. Portsmouth, NH: Heinemann, 2000.

Thornton, John. Africa and Africans in the Making of the Atlantic World, 1400-1800. Cambridge: Cambridge University Press, 1998.

Tignor, Robert L. W. Arthur Lewis and the Birth of Development Economics. Princeton: Princeton University Press, 2006.

Tuchman, Gaye. "Historical Social Science: Methodologies, Methods, and Meanings," in The Sage Handbook of Qualitative Research, edited by Norman K. Denzin and Yvonna S. Lincoln. Thousand Oaks, CA: Sage, 1994.

Turner, James E. "Africana Studies and Epistemology: A Discourse in the Sociology of Knowledge." in Africana Studies: A Disciplinary Quest for Both Theory and Method, edited by James L. Conyers, Jr., 91-107. Jefferson, N.C.: McFarland \& Company, 1997.

Turner, Joyce Moore, and W. Burghardt Turner. Caribbean Crusaders and the Harlem Renaissance. Urbana: University of Illinois Press, 2005.

Udogu, Ike. "Ethnicity and Theory in African Politics." in The Issue of Political Ethnicity Africa. edited by Ike Udogu, 13-34. England: Ashgate Publishing Limited, 2001.

Umoren, Imaobong D. Race Women Internationalists: Activist-Intellectuals and Global Freedom Struggles. Oakland, CA: University of California Press, 2018.

Vail, Leroy. ed. The Creation of Tribalism in Southern Africa. Oakland, CA: University of California Press, 1991.

Van Sertima, Ivan. They Came Before Columbus. New York: Random House 1976.

Ben III, Vinson. "Introduction: African (Black) Diaspora History, Latin American History." The Americas 63, no. 1 (2006): 1-18.

Vinson, R.T. The Americans are Coming!: Dreams of African American Liberation in Segregationist South Africa. Athens: Ohio University Press, 2012.

Von Eschen, Penny M. Race Against Empire: Black Americans and Anticolonialism, 1937-1957. Ithaca, New York: Cornell University Press, 1997.

Williams, Chancellor. The Destruction of Black Civilization: Great Issues of a Race from 4500 BC to 2000 AD. Chicago: Third World Press, 1987.

Worcester, Kent. CLR James: A Political Biography. Albany, NY: Suny Press, 1995.

Zimmerman, Andrew. Alabama in Africa: Booker T. Washington, the German Empire, and the Globalization of the New South. Princeton: Princeton University Press, 2010. 


\title{
CURRICULUM VITAE
}

\author{
Nicholas C. McLeod
}

\section{EDUCATION:}

2020 Ph.D., Pan-African Studies, University of Louisville.

Major: African History

Minor: African Diaspora History, Black Intellectual History.

Dissertation: "Practicing Pan-Africanism: West Indians and Governance

in Kwame Nkrumah's Ghana."

Comprehensive Exams: October 2018.

2016 M.A., Pan-African Studies, University of Louisville.

Major: African Diaspora History

M.A. Thesis: "Race, Rebellion, and Arab Muslim Slavery: The Zanj Rebellion In Iraq, 869 - 883 C.E."

2011 B.A., History, Bucknell University. Major: Political, Economics, Labor History

\section{COURSES TAUGHT:}

"History of Africa Since 1800", Departments of Pan-African Studies and History, Fall 2019

\section{TEACHING ASSISTANT:}

"Ancient Africa: Africa until 1800," Departments of Pan-African Studies and History, Spring 2018

"Formation of Modern Africa: From 1800 to the Near Present," Departments of Pan-African Studies and History, Spring 2017

"Introduction Caribbean Studies," Department of Pan-African Studies, Fall 2015

Trinidad and Tobago Study Abroad Program, Department of Pan-African Studies, University of Louisville and University of the West Indies at St. Augustine, Trinidad and Tobago, Summer 2015.

\section{PUBLICATIONS:}

"African Women's Sports" Encyclopedia Entry - The Daily Life of Women in World History: An Encyclopedia from Ancient Times to the Present [December 2020]

(Book Chapter) "It's Truly Ghanaian!: The Accra Evening News and Ghana's Benevolent Dictator, 19601964." In Reflections on Leadership and Institutions in Africa, Kenneth Kalu and Toyin Falola (eds.), Rowman \& Littlefield Publishers. [August 2020]

(Book Review) Female Highlife Performers in Ghana: Expression, Resistance, and Advocacy, by Nana Abena Amoah-Ramey, in The Journal of Global South Studies. [Spring 2020]

(Book Review) Religion and the Making of Nigeria, by Olufemi Vaughan, in The Journal of Global South Studies (Spring 2018).

(Book Review) Shackles of Iron: Slavery Beyond the Atlantic, by Steward Gordon, in World History Connected (February 2017).

(Book Review) Africanizing Democracies: 1980-Present, Andrea L. Arrington and Alicia C. Decker, History: Reviews of New Books (January 2016). 